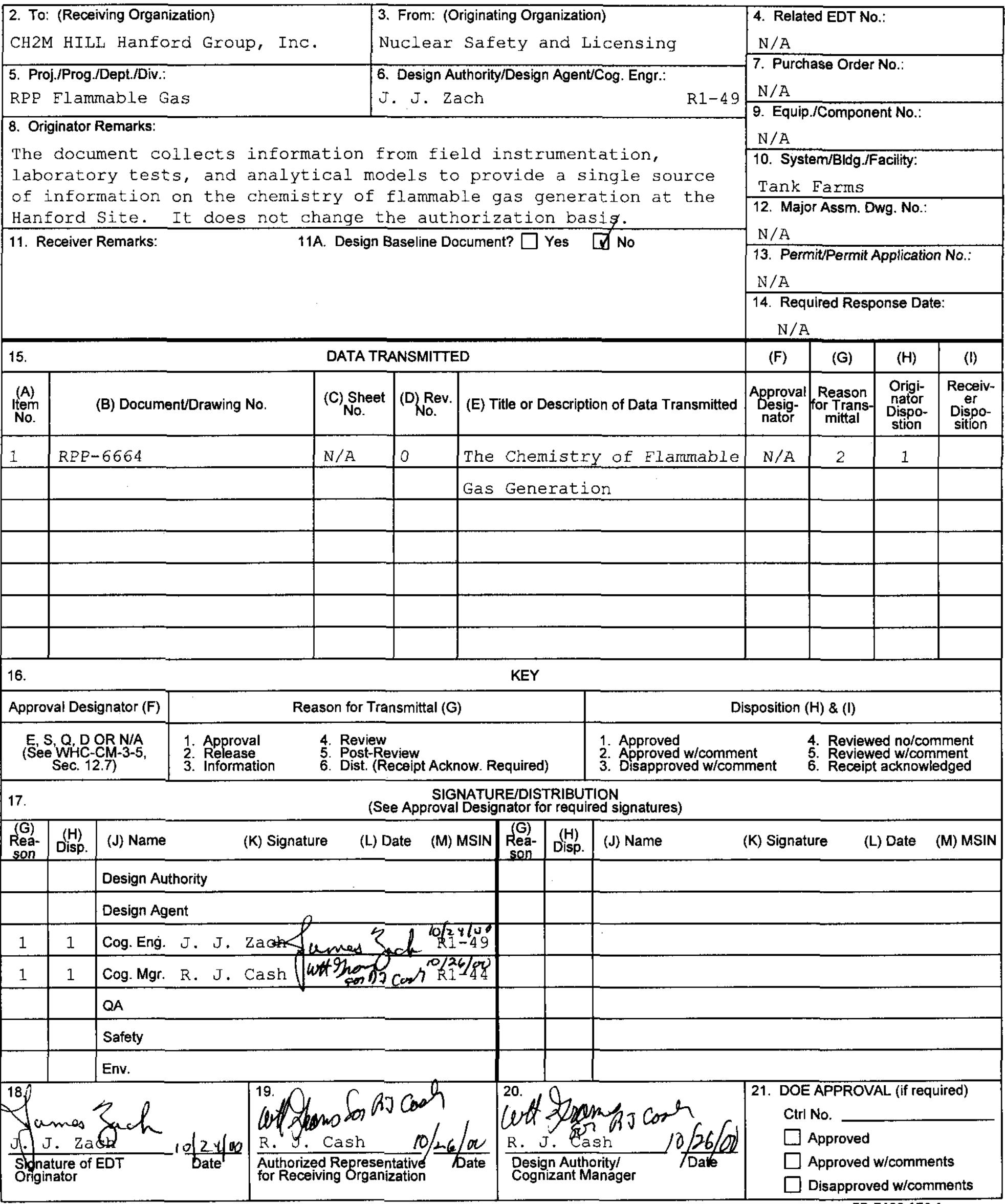


DISTRIBUTION SHEET

\begin{tabular}{|c|c|c|c|c|c|}
\hline \multirow{2}{*}{$\begin{array}{l}\text { To } \\
\text { CH2M HILL Hanford Group, Inc. }\end{array}$} & \multirow{2}{*}{\multicolumn{2}{|c|}{$\begin{array}{l}\text { From } \\
\text { Nuclear Safety and Licensing }\end{array}$}} & \multicolumn{3}{|c|}{ Page 1 of 3} \\
\hline & & & \multicolumn{3}{|c|}{ Date $10 / 25 / 2000$} \\
\hline \multirow{2}{*}{\multicolumn{3}{|c|}{$\begin{array}{l}\text { Project Title/Work Order } \\
\text { RPP- } 6664, \text { Rev. } 0 \\
\text { The Chemistry of Flammable Gas Generation }\end{array}$}} & \multicolumn{3}{|c|}{ EDT No. 625139} \\
\hline & & & \multicolumn{3}{|c|}{ ECN No. } \\
\hline Name & MSIN & $\begin{array}{c}\text { Text } \\
\text { With All } \\
\text { Attach. }\end{array}$ & Text Only & $\begin{array}{c}\text { Attach./ } \\
\text { Appendix } \\
\text { Only }\end{array}$ & $\begin{array}{l}\text { EDT/ECN } \\
\text { Only }\end{array}$ \\
\hline \multicolumn{6}{|l|}{ CH2M HILL Hanford Group } \\
\hline S. A. Barker & $\mathrm{R} 1-44$ & $h x$ & & & \\
\hline w. B. Barton & $\mathrm{R} 2-11$ & $\mathrm{x}$ & & & \\
\hline R. E. Bauer & $R 4-01$ & $\mathrm{x}$ & & & \\
\hline K. D. Boomer & $\mathrm{H} 4-02$ & $x$ & & & \\
\hline D. R. Bratzel. & $\mathrm{R} 1-44$ & $\mathrm{x}$ & & & \\
\hline R. J. Cash & $\mathrm{R} 1-44$ & $\mathrm{x}$ & & & \\
\hline A. F. Choho & R3-73 & $\mathrm{x}$ & & & \\
\hline J. M. Grigsby & $\mathrm{R} 1-44$ & $\mathrm{x}$ & & & \\
\hline D. C. Hedengren & R2-11 & $x$ & & & \\
\hline D. L. Herting & $\mathrm{T} 6-07$ & $\mathrm{x}$ & & & \\
\hline T. A. Hu & $\mathrm{R} 2-11$ & $\mathrm{x}$ & & & \\
\hline G. D. Johnson (3) & $\mathrm{R} 1-44$ & $\mathrm{x}$ & & & \\
\hline N. W. Kirch & $\mathrm{R} 2-11$ & $x$ & & & \\
\hline L. J. Kripps & $\mathrm{R} 1-44$ & $\mathrm{x}$ & & & \\
\hline C. E. Leach & $\mathrm{R} 1-44$ & $\mathrm{x}$ & & & \\
\hline D. J. McCain & $\mathrm{R} 2-11$ & $x$ & & & \\
\hline J. E. Meacham & $\mathrm{R} 1-49$ & $\mathrm{x}$ & & & \\
\hline J. C. Person & T6-07 & $\mathrm{x}$ & & & \\
\hline R. E. Raymond & $\mathrm{T} 4-08$ & $\mathrm{x}$ & & & \\
\hline D. A. Reynolds & $\mathrm{R} 2-11$ & $\mathrm{x}$ & & & $\because$ \\
\hline J. J. Zach (5) & $\mathrm{R} 1-49$ & $\mathrm{x}$ & & & \\
\hline Harry Calley (DOE HQ) & $46-60$ & $\mathrm{x}$ & & & \\
\hline C. A. Groendyke (6) & $\mathrm{H} 6-60$ & $\mathrm{x}$ & & & \\
\hline D. H. Irby & H6-60 & $x$ & & & \\
\hline J. S. Shuen & $\mathrm{H} 6-60$ & $\mathrm{x}$ & & & \\
\hline L. M. Stock & $\mathrm{R} 1-49$ & $\mathrm{x}$ & & & \\
\hline 6695 SW 86th Avenue, Portland, OR 97223 & & & & & \\
\hline Harry Babad & $\mathrm{R} 1-49$ & $\mathrm{x}$ & & & \\
\hline 2540 Cordoba Court, Richland, WA 99352-1609 & & & & & \\
\hline
\end{tabular}




\section{DISTRIBUTION SHEET}

To

CH2M HILI Hanford Group

Project Title/Work Order

RPP-6664, Rev. 0

The Chemistry of Flammable Gas Generation

Name

Kent Barefield and Charles Liotta

School of Chemistry and Biochemistry

Georgia Institute of Technology

Atlanta, Georgia 30332

Dr. Dan Meisel, Notre Dame Radiation Lab.

$\mathrm{U}$ of ND, Notre Dame, Indiana 46556

High-Level Waste Tank Advisory Panel

Charles S. Abrams (Chairman, worker Safety)

David Campbel1

Dr. Melvin W. Eirst

Charles W. Forsborg

Billy C. Hudson (Chairman, Chem. Reactions)

Dr. James Jackson

Mujid S. Kazimi (Chairman, TAP)

J. Louis Kovach

Thomas S. Kress

Thomas E. Larson

Dr. Donald T. Oakley

Dana A. Powers

Dr. George E. Schmauch

PNNL :

W. J. Apley

J. M. Bates

J. W. Brothers (3 copies)

S. A. Bryan

J. L. Buelt

L. L. Burger

D. M. Camaioni

J. A. Campbel1

S. D. Colson

J. C. Evans, Jr.

T. A. Ferryman
From

Nuclear Safety and Licensing

(2)

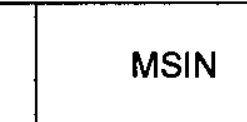

$\mathrm{R} 1-49$

$\mathrm{R} 1-49$

$\mid$

(2.

\begin{tabular}{l|l}
\hline \\
\hline
\end{tabular}

$\mathrm{R} 1-49$

\begin{tabular}{|l|r|}
\hline & \\
\hline & \\
\hline
\end{tabular}

\begin{tabular}{l|l|l|l} 
& & & \\
$\mathrm{R} 1-49$ & & $\mathrm{x}$ & \\
$\mathrm{R} 1-49$ & & $\mathrm{x}$ & \\
$\mathrm{R} 1-49$ & & $\mathrm{x}$ & \\
$\mathrm{R} 1-49$ & & $\mathrm{x}$ &
\end{tabular}

\begin{tabular}{|c|c|c|c|}
\hline $\begin{array}{c}\text { Text } \\
\text { With All } \\
\text { Attach. }\end{array}$ & Text Only & $\begin{array}{c}\text { Attach./ } \\
\text { Appendix } \\
\text { Only }\end{array}$ & $\begin{array}{c}\text { EDT/ECN } \\
\text { Only }\end{array}$ \\
\hline
\end{tabular}




\section{DISTRIBUTION SHEET}

To

CH2M HILL Hanford Group

From

Nuclear Safety and Licensing

Project Title/Work Order

RPP-6664, Rev. 0

The Chemistry of Flammable Gas Generation

Name

P. A. Gauglitz

R. E. Gephart

S. C. Goheen

R. T. Hallen

L. K. Holton, Jr.

E. W. Hoppe

J. L. Huckaby

W. L. Kuhn

M. A. Lilga

Jun Liu

I. A. Mahoney

G. B. Mellinger

P. A. Meyer

E. V. Morrey

Y. Onishi

T. M. Orlando

T. L. Page

L. R. Pederson

L. M. Puerrung

B. A. Pulsipher

S. D. Rassat

W. D. Samuels

C. W. Stewart

G. M. Stokes

J. L. Straalsund

D. M. Strachan

W. C. Weimer

B. E. Wells

Jonathan Young

Scott Slezak (Sandia National Laboratory)

Paul D'Entremont (Savannah River)
Page 3 of 3

Date $10 / 25 / 2000$

EDT No. 625139

ECN No.

MSIN $\quad$\begin{tabular}{c|c|c|c|c|}
$\begin{array}{c}\text { Text } \\
\text { With All } \\
\text { Attach. }\end{array}$ & Text Only & $\begin{array}{c}\text { Attach./ } \\
\text { Appendix } \\
\text { Only }\end{array}$ & $\begin{array}{c}\text { EDT/ECN } \\
\text { Only }\end{array}$ \\
\hline
\end{tabular}

K6-28

$\mathrm{K} 9-76$

P8-08

$\mathrm{K} 2-12$

H $6-61$

P8-08

K $7-15$

$\mathrm{K} 7-15$

$\mathrm{K} 2-12$

$\mathrm{K} 2-44$

$\mathrm{K} 7-15$

H6-61

K7-15

P7-28

K7-15

K8-88

K9-18

K2-50

K6-24

K5-12

K6-28

K2-44

K7-15

K9-95

K9-.02

K6-24

K9-09

K7-15

K7-97

it $x$

\begin{tabular}{|l|l|l}
\hline$x$ & \\
\hline$x$ & \\
\hline$x$ &
\end{tabular}

Onfy 
RPP-6664

Revision 0

\section{The Chemistry of Flammable Gas Generation}

Prepared for the U.S. Department of Energy Assistant Secretary for Environmental Management

\section{CH2MHILL}

Hanford Group, Inc.

Richland, Washington

Contractor for the U.S. Department of Energy

Office of River Protection under Contract DE-AC06-99RL14047 


\title{
The Chemistry of Flammable Gas Generation
}

\author{
Leon M. Stock, Consultant \\ CH2M HILL Hanford Group \\ Richland, WA 99352 \\ U.S. Department of Energy Contract DE-AC06-96RL13200
EDT/ECN: $625139 \quad$ UC: N. A.
Org Code: 7B300 Charge Code: 101972 \\ B\&R Code: N. A. Total Pages: 151
}

Key Words: Flammable Gas, Hydrogen, Ammonia, Convective Layer, Headspace, Non-Convective Layer, Crust, Buoyancy, Radiolysis, Chemical Reactions, Organic Complexant, Gas Solubility, Gas Formation, Thermolysis

Abstract: The document collects information from field instrumentation, laboratory tests, and analytical models to provide a single source of information on the chemistry of flammable gas generation at the Hanford site. It considers the 3 mechanisms of formation: radiolysis, chemical reactions, and thermal generation. An assessment of the current models for gas generation is then performed. The results are that the various phenomena are reasonably understood and modeled compared to field data.

TRADEMARK DISCLAIMER. Reference herein to any specific commercial product, process, or service by trade name, trademark, manufacturer, or otherwise, does not necessarily constitute or imply its endorsement, recommendation, or favoring by the United States Government or any agency thereof or its contractors or subcontractors.

Printed in the United States of America. To obtain copies of this document, contact: Document Control Services, P.O. Box 950, Mailstop H6-08, Richland WA 99352, Phone (509) 372-2420; Fax (509) 376-4989.

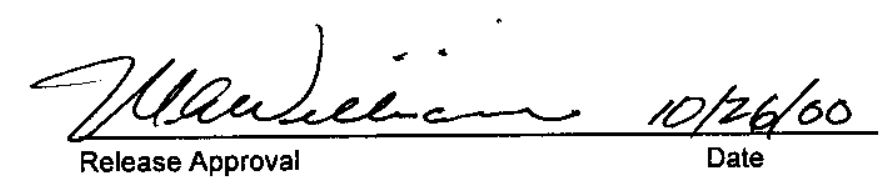

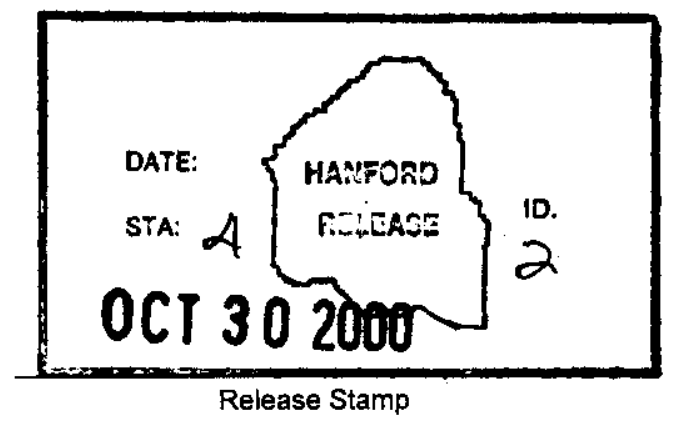

\section{Approved For Public Release}


LEGAL DISCLAIMER

This report was prepared as an account of work sponsored by an agency of the United States Government. Neither the United States Government nor any agency thereof, nor any of their employees, nor any of their contractors, subcontractors or their employees, makes any warranty, express or implied, or assumes any legal liability or responsibility for the accuracy, completeness, or any third party's use or the results of such use of any information, apparatus, product, or process disclosed, or represents that its use would not infringe privately owned rights. Reference herein to any specific commercial product, process, or service by trade name, trademark, manufacturer, or otherwise, does not necessarily constitute or imply its endorsement, recommendation, or favoring by the United States Government or any agency thereof or its contractors or subcontractors. The views and opinions of authors expressed herein do not necessarily state or reflect those of the United States Government or any agency thereof.

This report has been reproduced from the best available copy.

Available in paper copy and microfiche.

Available electronically at

http://www doe gov/bridge. Available for a processing fee to the U.S. Department of Energy and its contractors, in paper, from:

U.S. Department of Energy

Office of Scientific and Technical Information

P.O. Box 62

Oak Ridge, TN 37831-0062

phone: $865-576-8401$

fax: 865-576-5728

email: reports@adonis.osti.gov(423) 576-8401

Available for sale to the public, in paper, from:

U.S. Department of Commerce

National Technical Information Service

5285 Port Royal Road

Springfield, VA 22161

Phone: 800.553 .6847

fax: 703-605-6900

email: orders@ntis.fedworld.gov

online ordering:

http://www.ntis.gov/ordering.htm 
RPP-6664

Revision 0

\section{The Chemistry of Flammable Gas Generation}

Leon M. Stock, Consultant

\section{CH2MHILL}

Hanford Group, Inc.

P. O. Box 1500

Richland, Washington

Contractor for the U.S. Department of Energy

Office of River Protection under Contract DE-AC06-99RL14047 
RPP-6664 REV 0

This page intentionally left blank. 


\section{RPP-6664 REV 0}

\section{EXECUTIVE SUMMARY}

Many radioactive tank wastes generate and retain hydrogen, nitrogen, nitrous oxide, ammonia, methane, and other volatile organic compounds. Hydrogen is produced slowly during corrosion and the radiolysis of water. Radiolytic and chemical oxidation reactions of the organic complexants, phosphate esters, and hydrocarbons accelerate the rate of formation of hydrogen. Nitrogen, nitrous oxide, ammonia, methane, and the other volatile substances are also produced during the oxidation reactions of the organic compounds. Gas formation and organic oxidation are closely coupled reaction systems. The chemistry of these processes is discussed in this report.

The Tank Characterization Program provides an important technical basis for the formulation of the chemistry discussed in this report. The relationship between the propensity for gas formation and the organic content of the waste was recognized early in the tank characterization work. This work also showed that the organic compounds were widely distributed in the waste tanks and that the wastes contained remnants of the original complexants, phosphate esters, and hydrocarbons. Small and large fragments of the original complexants, homologous series of organic compounds derived from the normal paraffin hydrocarbons, and products of chemical reactions of the phosphate esters have been identified. The organic waste constituents are slowly degrading to common end products including formate, acetate and oxalate ions. The eventual reaction product is inorganic carbonate ion.

Targeted technical work has shown that gas formation and organic compound oxidation are initiated by the radioactive decay process, by thermal chemical reactions, and by other chemical reactions that do not involve reactive free radicals. The decay processes produce hydrogen atoms, hydroxyl radicals, nitric oxide, and nitrogen dioxide. Similar radical reagents can also be obtained by thermal reactions.

$$
\text { Radiolytic and thermal processes } \rightarrow \mathrm{H}, \mathrm{OH}, \mathrm{NO}, \mathrm{NO}_{2}
$$

Organic constituents + reactive free radicals $\rightarrow$ organic free radicals

Organic free radicals $+\mathrm{NO}$ and $\mathrm{NO}_{2} \rightarrow$ reactive organic intermediates 


\section{RPP-6664 REV 0}

Other chemical processes that do involve reactive free radicals occur in parallel.

$$
\text { Organic constituents }+ \text { ionic reagents } \rightarrow \text { reactive organic intermediates }
$$

The reactive organic intermediates formed in these reactions are transformed into other substances more rapidly than are the compounds from which they were formed. The gases that are formed in the waste are obtained in these later stages of the chemistry.

\section{Reactive organic intermediates $\rightarrow \rightarrow$ oxidized organic compounds + gas}

Characterization work and laboratory studies have identified the principal products of the reactions of the complexants and the phosphate esters. For example, the principal degradation pathway for ethylenediaminetetraacetate ion involves the successive loss of two carbon fragments until the compound is converted to oxalate and formate ion. Tributyl phosphate reacts in alkaline solution to produce butanol and dibutylphosphate ion. A broad array of organic compounds including homologous series of alkanes, alkenes, alcohols, aldehydes and ketones, and nitriles are formed from the original hydrocarbons.

A chemical model for the elementary radiolytic and chemical reactions provides a quantitative basis for the discussion of the initial reaction sequences. In addition, the relative rates of disappearance of the principal complexants and phosphate esters have been determined. Among the four original complexants, hydroxyethylethylenediaminetriacate ion and glycolate ion decompose more rapidly than ethylenediaminetetraacetate or citrate ion. Tributyl phosphate decomposes much more rapidly than bis(2-ethylhexyl)phosphate ion. Formate ion is the most reactive compounds among the common highly fragmented end products such as acetate and oxalate ion. The hydrocarbons react much more slowly than the complexants or tributyl phosphate.

Chemical reactions of the waste constituents and of the reactive intermediates produced during the radiolytic reactions occur simultaneously. The original constituents with hydroxyl groups undergo aluminate ion-catalyzed oxidation reactions. Aldehydes that are formed during the radiolytic and thermal reactions are converted into carboxylate ions in oxidation reactions catalyzed by hydroxide ion. The reactive nitroso and nitro compounds formed during the reactions of the organic radicals with nitric oxide and nitrogen dioxide react with water to give 


\section{RPP-6664 REV 0}

aldehydes and ketones. These reactions and other related processes that are described more fully in the report blend with the initial thermal and radiolytic reactions to provide a comprehensive chemical reaction model that is consistent with the results of the characterization program and other technical investigations.

Gas formation is a direct consequence of the oxidation reactions of organic molecules. Some hydrogen is formed by hydrogen atom abstraction reactions, but the predominant sources of hydrogen are the hydroxide ion-catalyzed oxidation reactions of the intermediate aldehydes, for example, during the conversion of formaldehyde into formate ion. The reactions of the nitroso and nitro compounds yield nitrosyl anion and hydroxylamine. These two substances decompose to form nitrogen, nitrous oxide, and ammonia. Ammonia is also formed by the hydrolysis of nitriles and amides that are formed by the oxidation of the original complexants. Many volatile and some not so volatile organic compounds are found in the dome spaces and in the retained gas. The gases contain methane and lesser amounts of other low molecular weight compounds such as propane, cyclopropane, propene, propanol, acetone, and nitropropane. These substances are also produced by the reaction sequences described in the previous paragraphs.

The rates of the thermal and radiolytic gas generating reactions have been determined for representative wastes. The rates of the radiolytic reactions like the thermal reactions have an exponential dependence on the temperature as a consequence of the fact that the gases are generated in chemical reactions that occur after the initial radiolytic reactions. The results of the laboratory investigation indicate the hydrogen-to-(nitrous oxide + nitrogen) mole ratio is greater than one. The hydrogen-to-(nitrous oxide + nitrogen) ratios for gases in convective layers are similar inasmuch as these types of waste do not retain gas and the rates of gas formation and release are comparable. The hydrogen-to-(nitrous oxide + nitrogen) ratio is much larger for the gases that are retained in the nonconvective layers. No satisfactory explanation has been offered for this observation. However, the change in the ratio apparently is a consequence of the fact that the gases are retained for many years in nonconvective materials. In this situation, slow radiolytic reactions such as the formation of hydrogen and nitrogen from ammonia may become important. It is intriguing that the hydrogen-to-nitrogen ratio in the nonconvective layers of several tanks is about three to one, the same ratio as in ammonia. 


\section{RPP-6664 REV 0}

Lastly, an empirical model has been formulated for the prediction of the rate of generation of hydrogen in tank waste. The model was formulated on the basis of technical information about the dependence of the rate of hydrogen generation on the chemical composition of the waste and its temperature. The model identifies the amount of hydrogen formed during corrosion, water radiolysis, and organic compound oxidation. The rate of hydrogen formation has a first-order dependence on the organic content of the liquid portion of the waste, consequently wastes with soluble organic compounds have the highest rates of hydrogen formation. The predictions of the model are about twice as large as the known release rates. 


\section{ACKNOWLEDGEMENTS}

Many persons generously provided information and suggestions for sources of information in the preparation of this report and contributed their special insights concerning different aspects of the problem. Any list would be incomplete, but it is appropriate to mention Steve Agnew, Blaine Barton, Roger Bauer, Chris Brevick, Sam Bryan, Jim Campbell, Clark Carlson, Bob Cash, Don Camaioni, Bill Cowley, Jim Field, Rich Hallen, Albert Hu, Jim Huckaby, Jerry Johnson, Nick Kirch, Louis Kovach, Dennis Lauhala, Lenna Mahoney, Joe Meacham, Dan Meisel, Larry Pederson, Dan Reynolds, Edward Siciliano, Leslie Stauffer, Marcus Stauffer, and Chuck Stewart. 
RPP-6664 REV 0

This page intentionally left blank. 


\section{CONTENTS}

2.0 GAS FORMATION AND ORGANIC COMPOUND OXIDATION IN WASTE .........2-1

2.1 OBSERVATIONS OF GAS FORMATION IN SINGLE-SHELL AND

DOUBLE-SHELL TANKS

2.1.1 Tank Dome Space Monitoring ..............................................................2-1

2.1.2 Retained Gas Sampling Program ..........................................................2-2

2.2 EVIDENCE FOR ORGANIC COMPOUND OXIDATION FROM

CHARACTERIZATION STUDIES ...............................................................2-2

2.2.1 Organic Complexant Species in Solid and Liquid Samples from Single-Shell and Double-Shell Tanks .....................................................2-5

2.2.2 Oxalate Ion Content of Solid and Liquid Samples from Single-Shell and Double-Shell Tanks ....................................................2-10

2.2.3 Organic Solvent Species in Samples from Single-Shell and

Double-Shell Tanks $2-14$

2.3 GAS FORMATION AND ORGANIC OXIDATION: CHEMICALLY COUPLED PROCESSES

3.0 THE OXIDATION OF ORGANIC COMPLEXANTS AND SOLVENTS.................... 3-1

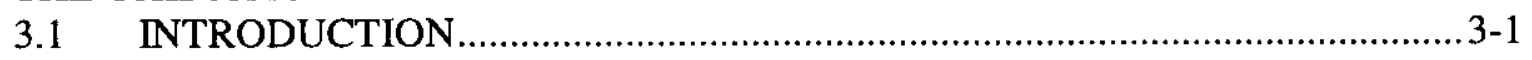

3.2 PRODUCT DISTRIBUTIONS AND RELATIVE RATES OF

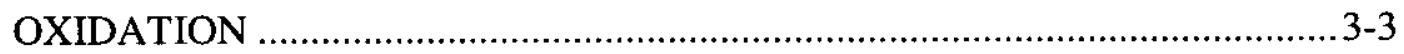

3.2.1 Product Distributions and Relative Rates for Complexants......................3-3

3.2.2 Product Distributions and Relative Rates for Solvents .............................3-9

3.3 REACTION PATHWAYS FOR ORGANIC OXIDATION ............................. 3-13

3.3.1 Radiolytic and Thermal Initiation .......................................................

3.3.2 Radical Reactions of the Ethylenediaminetetraacetate Family …............3-22

3.3.3 Radical Reactions of the Hydrocarbons .................................................3-26

3.3.4 Radical Reactions of the Phosphate Esters .............................................3-28

3.3.5 Reaction Pathways of Organic Intermediates .......................................3-31

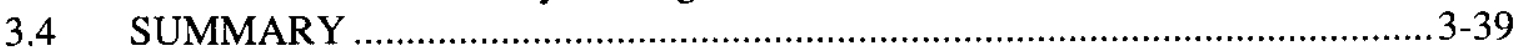

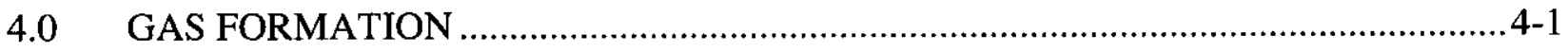

$4.1 \quad$ INTRODUCTION.................................................................................

4.2 ORIGINS OF HYDROGEN …………...................................................... 4-1

4.2.1 Hydrogen from the Corrosion of Steel .................................................. 4-1

4.2.2 Hydrogen from the Radiolysis of Water .................................................4-2

4.2.3 Hydrogen from Organic Compounds ......................................................4-3

4.3 ORIGINS OF NITROGEN-CONTAINING GASES ………..............................4-4

4.4 LABORATORY INVESTIGATIONS OF WASTE .......................................... $4-9$ 
4.5.4 Methane and Volatile Organic Compound Formation..........................4-22

4.5.5 Role of Oxygen ................................................................... 4-23

4.6 EQUIVALENCE OF ORGANIC OXIDATION AND GAS

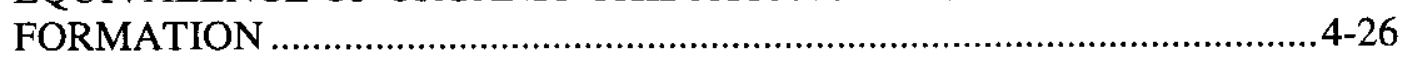

4.7 REACTIONS OF GASES IN WASTE...............................................4-30

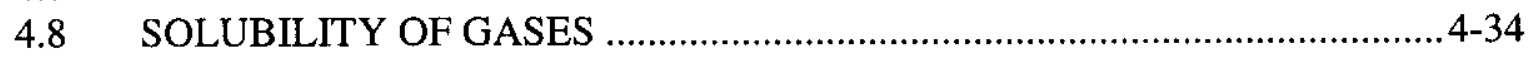

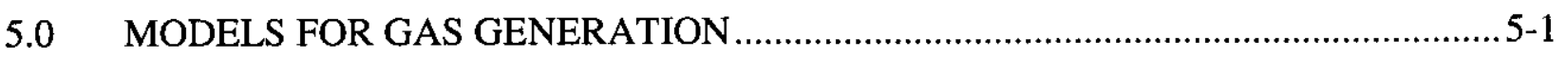

5.1 PRELIMINARY ASSESSMENTS OF HYDROGEN GENERATION

5.1.1 Thermal Generation Rates............................................................... 5-1

5.1 .2 Radiolytic Rates ......................................................................5-3

5.2 CURRENT ASSESSMENTS OF HYDROGEN GENERATION RATE..........5-4

5.2.1 Thermal Generation Rates..............................................................5-4

5.2.2 Radiolytic Rates .................................................................. 5-7

5.2 .3 Corrosion Rates ............................................................................ 5-10

5.3 APPLICATION OF EMPIRICAL MODEL FOR HYDROGEN

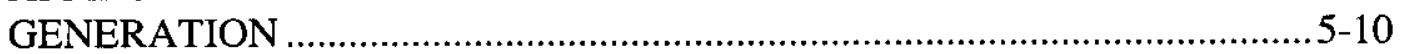

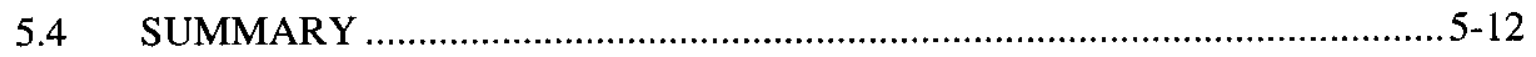

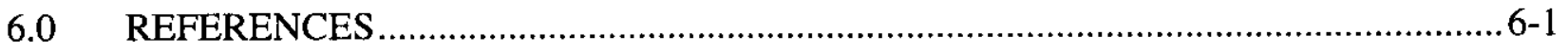

\section{FIGURES}

Figure 3-1. Principal Reaction Pathways for the Oxidation of Organic Compounds.

Figure 3-2. Consumption of Hydroxyethylethylenediaminetriacetate and Appearance of Principal Organic Products during the Thermal Reaction at $90^{\circ} \mathrm{C}$ in a Simulated Waste under Argon.

Figure 3-3. Reaction Pathways for the Oxidation of Ethylenediaminetriacetate.

Figure 3-4. Reaction Profile for the Radiolysis of Dibutyl Phosphate.

Figure 3-5. Phosphorous-Based Product Mixtures.

Figure 3-6. Hydrogen Atom Abstraction and Electron Transfer Reactions in Kinetic Model during Radiolysis of Formate and Glycinate Ions in Aqueous Alkaline Solutions of Sodium Nitrite and Sodium Nitrate.

Figure 3-7. Comparison of the Experimental Results for the Radiolysis of Formate Ion with the Predictions of a Kinetic Model.

Figure 4-1. The Relationship Between Hydrogen Generation Efficiency and the Number of Carbon-Hydrogen and Nitrogen-Hydrogen Bonds in Organic Complexants. 
Figure 4-1. The Relationship Between Hydrogen Generation Efficiency and the Number of Carbon-Hydrogen and Nitrogen-Hydrogen Bonds in Organic Complexants.

Figure 4-2. Ammonia G Values for the Radiation of a Waste Simulant.

Figure 4-3. Generation of Hydrogen, Nitrogen, Nitrous Oxide, and Ammonia during the Thermal Decomposition of Hydroxyethylethylenediaminetriacetate Ion at $90^{\circ} \mathrm{C}$ in a Simulant.

Figure 4-4. Generation Efficiency Values for the Decomposition of Nitrous Oxide and Product Formation at Temperatures Ranging from $25^{\circ} \mathrm{C}$ to $150^{\circ} \mathrm{C}$.

Figure 4-5. Generation Efficiency Values for the Decomposition of Nitrous Oxide and Hydrogen and Product Formation at Temperatures Ranging from $60^{\circ} \mathrm{C}$ to $150^{\circ} \mathrm{C}$

Figure 4-6. The Relationship between the Generation Efficiency of Ammonia and the Total Dose for the Formation of Ammonia from Hydrogen and Nitrogen at $90^{\circ} \mathrm{C}$.

Figure 5-2. Relationship between Calculated and Observed Radiolytic Hydrogen Generation Rates.

\section{TABLES}

Table 2-1. Best Basis Inventory of Organic Carbon Content in Single-Shell Tanks from 1998. (2 sheets).

Table 2-2. Best Basis Inventory of Organic Carbon Content in Double-Shell Tanks from 1998.

Table 2-3. Concentrations of Organic Species in Weight Percent (Wet) for Samples from Single-Shell Tanks. (2 sheets).

Table 2-4. Concentrations of Organic Species in Weight Percent (Wet) for Samples from Double-Shell Tanks.

Table 2-5. Inventory of Acetate, Formate, and Oxalate Ions Determined by Analysis of Cores from Double-Shell Tanks. (2 sheets).

Table 2-6. Organic Carbon and Oxalate Ion Contents for Single-Shell Tanks. (2 sheets) ......2-11

Table 2-7. Organic Carbon and Oxalate Ion Contents for Double-Shell Tanks. (2 sheets).....2-12 


\section{RPP-6664 REV 0}

Table 2-9. Volatile Organic Compounds at Concentrations Greater than One Milligram per Cubic Meter in the Ventilation Stack of Tank 241-C-106 During Sluicing on March 7, 1999. (2 sheets) .......................................................................... 16

Table 2-10. Organic Compounds at Concentrations Greater than One Milligram per Cubic Meter in a Retained Gas Sample from Tank 241-SY-101.

Table 2-11. Concentrations of Organic Gases in the Gas-rich Slurry in Tank 241-SY-101 Before Waste Transfers in 2000.

Table 2-12. Concentrations of Soluble Organic Compounds in Gas-Rich Slurry in Tank 241-SY-101 Before Waste Transfers in 2000. (2 sheets)

Table 3-1. Principal Products of the Radiolysis of Complexants in Simultants. (2 sheets) .......3-4

Table 3-2. Relative Rates of Disappearance of Organic Complexants and Selected Derivatives During Radiolysis of Simulants at $20^{\circ} \mathrm{C}$ or $25^{\circ} \mathrm{C}$.

Table 3-3. Relative Reactivity of Organic Compounds in Hydrogen Atom Abstraction Reactions in Homogeneous Alkaline Aqueous Solution at $25^{\circ} \mathrm{C}$

Table 3-4. Kinetic Reaction Model for Radiolysis in Aqueous Alkaline Solutions of Sodium Nitrite. (2 sheets)

Table 3-5. The Radicals Produced from Glycolate, Citrate, Ethylenediaminetetraacetate, and Glycinate Ions by Hydrogen Atom Abstraction.

Table 3-6. The Radicals Produced from Glycolate, Citrate, Ethylenediaminetetraacetate, and Glycinate Ions by Electron Transfer and Decarboxylation.

Table 3-7. Intermediate Products of the Recombination Reactions of Radicals Derived from Glycolate, Citrate, Ethylenediaminetetraacetate, and Glycinate Ions

Table 3-8. Intermediate Products of the Reactions of Radicals Derived from Tributyl Phosphate.

Table 3-9. Intermediate Products of the Reactions of 2- and 3-Heptanyl Radicals Derived from Sodium bis(2-Ethylhexyl)phosphate.

Table 4-1. Generation Efficiency Values in Molecules per100 Electron-Volts for the Initial Products of the Radiolysis of Pure Water.

Table 4-2. Generation Efficiency Values in Molecules per100 Electron-Volts for the Formation of Nitrous Oxide in Waste Simulants.

Table 4-3. Generation Efficiency Values in Molecules per 100 Electron-Volts for the Formation of Nitrogen in Waste Simulants. 


\section{RPP-6664 REV 0}

Table 4-4. Generation of Hydrogen, Nitrogen, and Nitrous Oxide during the Thermal Decomposition of Glycolate in a Simulant.

Table 4-5. Average Temperature, Dose Rate, Reactive Carbon Content, and Waste Weight for Selected Waste Tanks

Table 4-6. Experimentally Measured Activation Parameters and Generation Efficiency Values for Gas Generation for Selected Waste Samples. (2 sheets)

Table 4-7. Experimentally Measured Gas Generation Rates for Selected Waste Samples.

Table 4-8. Arrhenius Parameters for Hydrogen Formation During Radiolysis.

Table 4-9. Moles of Decomposition Product per 100 Moles of Hydroxyethylethylenediaminetriacetate after 200 Hours in Simulated Hanford Site Waste at $120^{\circ} \mathrm{C}$.

Table 4-10. The Organic Content of the Waste in Tank 241-SY-101 in 1980 and in 1995 in Thousands of Moles.

Table 4-11. Predicted Rates of Oxidation of Organic Carbon to Oxalate and Carbonate Ion in Tank 241-AN-105 Based upon Observed Rates of Gas Generation.

Table 4-12. Henry's Law Constants Appropriate for Gases in the Liquid Phase of Tank 241-SY-101 Based on Experimental Measurements with Simulants and the Schumpe Model.

Table 4-13. Soluble Gas Concentrations Determined During Retained Gas Investigations. (5 sheets)

Table 5-1. Calculated and Observed Rates of Hydrogen Generation. (2 sheets). $5-10$ 


\section{RPP-6664 REV 0}

\section{TERMS}

$\begin{array}{ll}\text { DBP } & \text { dibutyl phosphate ion } \\ \text { EDDA } & \text { ethylenediaminediacetate ion } \\ \text { EDTA } & \text { ethylenediaminetetraacetate ion } \\ \text { ED3A } & \text { ethylenediaminetriacetate ion } \\ \text { G } & \text { molecules/100 eV } \\ \left.\text { G( } \mathrm{H}_{2}\right) & \text { hydrogen generation efficiency, molecules } \mathrm{H}_{2} / 100 \mathrm{eV} \\ \mathrm{HDW} & \text { Hanford defined waste } \\ \text { HEDTA } & \text { hydroxyethylethylenediaminetriacetate ion } \\ \text { IDA } & \text { iminodiacetate ion } \\ \mathrm{k} & \text { reaction rate constant } \\ M & \text { moles per liter } \\ \text { MBP } & \text { monobutylphosphate ion } \\ \text { NPH } & \text { normal paraffin hydrocarbon } \\ \text { NTA } & \text { nitrilotriacetate ion } \\ \text { PUREX } & \text { plutonium-uranium extraction } \\ \text { s-EDDA } & \text { s-ethylenediaminediacetate ion } \\ \text { TBP } & \text { tributyl phosphate } \\ \text { TOC } & \text { total organic carbon } \\ \text { u-EDDA } & \text { u-ethylenediaminediacetate ion }\end{array}$




\section{RPP-6664 REV 0}

\subsection{INTRODUCTION}

Monitoring of the gas in the tank dome spaces, characterization of the gases retained in the solid and liquid tank wastes, and other studies have established that many radioactive tank wastes generate and retain mixtures of hydrogen, nitrogen, nitrous oxide, and ammonia together with smaller amounts of methane and other volatile hydrocarbons. The technical investigations discussed in this report have established the principal reaction pathways for the generation of these gases. In brief, hydrogen is generated through corrosion and the radiolysis of water. Additional hydrogen and the other organic and inorganic gases are generated through radiolytically and thermally initiated free radical and ionic chemical reactions of the organic constituents. The organic reactions and the gas generation reactions are coupled chemically and occur in parallel. Consequently, a close relationship exists between the rate of gas generation and the organic composition of the waste.

The widespread distribution of organic compounds in the tank wastes has been established by the analysis of core samples and by the analysis of samples from the dome spaces. The characterization program also has established that the original organic complexants and solvents have been oxidized to form new organic compounds, recognizable as remnants of the original constituents, and small molecules. Some small molecules such as methane, propane, and pentane evolve from the waste, but others such as sodium formate and sodium oxalate are retained. The occurrence of these fragmented and oxidized compounds in the waste and in the dome space is a harbinger of flammable gas generation in the waste tanks.

Broadly speaking, information about gas generation in the waste tanks, including the influences of inorganic and organic constituents, tank temperature, and radiation dose on the rates and products of the ongoing chemical processes, is required for assessing the behavior of the waste during interim storage, evaluating monitoring operations, designing control strategies, planning mitigation operations, and eventually for retrieving the waste. The information discussed in this report provides a technical basis for continued safe interim storage and for planning future operations. Two illustrations demonstrate the technical relationship. First, the rates at which the organic molecules are oxidized and the pathways by which these oxidation reactions occur determine the rates of gas formation. The rates of gas formation are needed, for example, to verify that any given waste tank, transfer line, or receiver tank has sufficient ventilation to ensure that flammable gases are maintained at safe concentrations. Indeed, tank sampling and the rates of gas generation developed from the models discussed at the end of this report have shown that the current ventilation systems are capable of handling the steady-state release of gas. Second, information about the pathways by which the various gases are generated and the chemical factors governing the generation rates guide the planning of operations so that the formation or release of undesirable quantities of hydrogen, ammonia, or nitrous oxide can be avoided. 


\section{RPP-6664 REV 0}

The evidence for formation of gases and the broad distribution of organic compounds in the wastes and the oxidation of those compounds is discussed in Section 2.0. The work that has been done to identify the principal radiolytic and thermal chemical reactions governing the oxidation of organic compounds and the generation of gases is discussed in Sections 3.0 and 4.0. Related work concerning gas solubility and reactivity also is considered in Section 4.0. The work discussed in these sections underpins the practical, empirical model for predicting hydrogen generation in tank wastes that is described in Section 5.0. 


\subsection{GAS FORMATION AND ORGANIC COMPOUND OXIDATION IN WASTE}

The broad occurrence of gas formation in the Hanford Site tank farms has been -described and documented (Johnson et al. 1997). The evidence for the coupling of gas formation with organic compound oxidation is outlined in this section as a prelude to the discussion of targeted laboratory work in the following sections.

\subsection{OBSERVATIONS OF GAS FORMATION IN SINGLE-SHELL AND DOUBLE-SHELL TANKS}

\subsubsection{Tank Dome Space Monitoring}

The concentrations of the gases in the dome spaces of the waste tanks have been studied for several years by several different methods (Mahoney et al. 2000). Samples are regularly collected from the standard hydrogen monitoring systems cabinets for laboratory analysis, as described by McCain (1999). The results from analysis of 42 tanks, most of which are on the flammable gas watch list, have been presented by Mahoney et al. (2000). The tank-average concentrations of hydrogen and nitrous oxide, which are influenced by ventilation, range from about $10 \mathrm{ppmv}$ to about $1,000 \mathrm{ppmv}$. The hydrogen concentrations are well below the lower flammability limit of 40,000 ppmv.

The concentrations of hydrogen and other gases in the single-shell tanks also have been investigated by collecting and analyzing samples from 110 single-shell tanks (Huckaby et al. 1996). The dome space monitoring program has provided information about the concentrations of hydrogen, methane, nitrous oxide, and ammonia (Mahoney et al. 2000). The concentrations of hydrogen are often below the detection limit, but the hydrogen concentrations are greater than $100 \mathrm{ppmv}$ in about 40 single-shell tanks. The concentrations of nitrous oxide and ammonia also range broadly. The concentration of ammonia exceeds $100 \mathrm{ppm}$ in approximately 40 tanks, and the concentration of nitrous oxide exceeds $100 \mathrm{ppm}$ in about 30 tanks.

The investigation of the organic compounds in these samples revealed that more than 1,200 different organic compounds were present (Stock and Huckaby 2000). The highest concentration of methane, $16 \mathrm{ppmv}$, was observed above the liquid organic layer of tank 241. C-103. The dome space in the tank also contained $2,100 \mathrm{mg} / \mathrm{m}^{3}$ of organic material. Measurable amounts of volatile organic material have been detected in virtually every waste tank (Mahoney et al. 2000).

These observations collectively indicate that these gases are generated throughout the tank farms and that the rates of formation and release of hydrogen and the other gases differ significantly. 


\section{RPP-6664 REV 0}

\subsubsection{Retained Gas Sampling Program}

The Retained Gas Sampling Program has provided definite information about the composition of the gas that is being retained in the solid and liquid wastes in the tanks. Samples of retained gases have been collected and analyzed for 14 tanks (Shekarriz et al. 1997; Mahoney et al. 1999). The total gas content and the relative amounts of hydrogen, nitrogen, nitrous oxide, methane, and ammonia were evaluated. The gas contents and gas compositions varied significantly. For example, the amount of hydrogen ranged from less than 20 mol\% in samples of liquid waste to over $70 \mathrm{~mol} \%$ in samples of solid waste. The concentrations of these gases greatly exceeded the concentrations of methane and the other low molecular weight organic compounds.

The results of the RGS program provide definite information about the composition of the gas that is being formed and being retained in the waste. The work affirms the conclusion that gas generation occurs broadly in the Hanford Site Wastes.

\subsection{EVIDENCE FOR ORGANIC COMPOUND OXIDATION FROM CHARACTERIZATION STUDIES}

Topical reports concerning the hazards associated with organic solvents (Cowley et al. 1998) and organic complexants (Meacham et al. 1998) describe the widespread distribution of these materials in the Hanford Site waste tanks. In brief, considerable quantities of both classes of materials were used and eventually discharged as waste. Allen (1976) has estimated $8.8 \times 10^{5} \mathrm{~kg}$ of glycolic acid, $8.5 \times 10^{5} \mathrm{~kg}$ of citric acid, $8.3 \times 10^{5} \mathrm{~kg}$ of hydroxyethylethylenediaminetriacetic acid, and $2.2 \times 10^{5} \mathrm{~kg}$ of ethylenediaminetetraacetic acid were used. Sederberg and Reddick (1994) have estimated $7.2 \times 10^{5} \mathrm{~kg}$ of tributyl phosphate (TBP) and $1.3 \times 10^{6} \mathrm{~kg}$ of normal paraffin hydrocarbons (NPHs) were used. Other organic compounds used during Hanford Site operations include nitriloacetic acid, oxalic acid, bis(2-ethylhexyl)phosphoric acid, dibutyl butylphosphonic acid, carbon tetrachloride, and methyl isobutyl ketone. The treatment of the wastes with sodium hydroxide left the neutral organic solvents unchanged, but converted the acidic organic complexants - with the exception of hydrophobic sodium bis(2-ethylhexyl)phosphate — into water soluble salts.

Studies of the waste operations by Agnew et al. (Agnew 1995, 1996; Agnew et al. 1995, 1997) have provided estimates of the distribution of the principal organic compounds in the tank farms. The names and structures of these substances are presented for convenience:

- Glycolate ion: $\mathrm{HOCH}_{2} \mathrm{CO}_{2}{ }^{-}$

- Citrate ion: $\mathrm{HOC}\left(\mathrm{CH}_{2} \mathrm{CO}_{2}^{-}\right)_{2}\left(\mathrm{CO}_{2}^{-}\right)$

- Hydroxyethylethylenediaminetriacetate ion (HEDTA): $\left(\mathrm{O}_{2} \mathrm{CCH}_{2}\right)_{2} \mathrm{NCH}_{2} \mathrm{CH}_{2} \mathrm{~N}\left(\mathrm{CH}_{2} \mathrm{CO}_{2}^{-}\right)\left(\mathrm{CH}_{2} \mathrm{CH}_{2} \mathrm{OH}\right)$

- Ethylenediaminetetraacetate ion (EDTA): $\left(\mathrm{O}_{2} \mathrm{CCH}_{2}\right)_{2} \mathrm{NCH}_{2} \mathrm{CH}_{2} \mathrm{~N}\left(\mathrm{CH}_{2} \mathrm{CO}_{2}\right)_{2}$

- Nitrilotriacetate ion (NTA): $\mathrm{N}\left(\mathrm{CH}_{2} \mathrm{CO}_{2}^{-}\right)_{3}$ 
- Tributyl phosphate (TBP): $\left(\mathrm{CH}_{3} \mathrm{CH}_{2} \mathrm{CH}_{2} \mathrm{CH}_{2} \mathrm{O}\right)_{3} \mathrm{P}(=\mathrm{O})$

- Normal paraffin hydrocarbon (NPH): Typically $\mathrm{C}_{12} \mathrm{H}_{26}, \mathrm{C}_{13} \mathrm{H}_{28}, \mathrm{C}_{14} \mathrm{H}_{30}$

- bis(2-Ethylhexyl)phosphate ion: $\left(\mathrm{CH}_{3} \mathrm{CH}_{2} \mathrm{CH}_{2} \mathrm{CH}_{2} \mathrm{CH}\left(\mathrm{CH}_{2} \mathrm{CH}_{3}\right) \mathrm{CH}_{2} \mathrm{O}\right)_{2} \mathrm{P}(=\mathrm{O}) \mathrm{O}^{-}$

- Dibutyl butylphosphonate: $\left(\mathrm{CH}_{3} \mathrm{CH}_{2} \mathrm{CH}_{2} \mathrm{CH}_{2} \mathrm{O}\right)_{2} \mathrm{P}(=\mathrm{O})\left(\mathrm{CH}_{2} \mathrm{CH}_{2} \mathrm{CH}_{2} \mathrm{CH}_{3}\right)$

- Methyl isobutyl ketone: $\left(\mathrm{CH}_{3}\right)_{2} \mathrm{CHCH}_{2} \mathrm{C}(=\mathrm{O}) \mathrm{CH}_{3}$

Analytical measurements of the total organic carbon (TOC) contents of the cores withdrawn in the waste characterization program have been supplemented, where necessary, by other measurements and engineering estimates to provide the best basis inventory. The organic carbon inventories for the single- and double-shell tanks are summarized in Tables 2-1 and 2-2.

Table 2-1. Best Basis Inventory of Organic Carbon Content in Single-Shell Tanks from 1998. (2 sheets)

\begin{tabular}{|c|c|c|c|c|c|c|c|c|}
\hline Tank & $\begin{array}{l}\mathrm{TOC} \\
(\mathbf{k g})\end{array}$ & Basis* & Tank & $\begin{array}{l}\text { ToC } \\
\text { (kg) }\end{array}$ & Basis* & Tank & $\begin{array}{r}\text { TOC } \\
(\mathbf{k g}) \\
\end{array}$ & Basis* \\
\hline 241-A-101 & 19,600 & $S$ & 241-C-101 & 476 & $\mathrm{E}$ & $241-\mathrm{T}-108$ & 20 & $\mathbf{M}$ \\
\hline 241-A-102 & 2,890 & $S$ & $241-\mathrm{C}-102$ & 1,880 & $S$ & 241-T-109 & 51 & $\mathbf{M}$ \\
\hline $241-A-103$ & 15,200 & $\mathrm{~S}$ and $\mathrm{E}$ & 241-C-103 & 4,100 & $S$ & $241-\mathrm{T}-110$ & 5,550 & $\mathrm{E}$ \\
\hline $241-A-104$ & 0 & $M$ & 241-C-104 & 14,000 & $S$ and $E$ & $241-T-111$ & 6,800 & $S$ \\
\hline 241-A-105 & 0 & $M$ & 241-C-105 & 1,010 & $S$ & 241-T-112 & 1,010 & $E$ \\
\hline 241-A-106 & 4,910 & $S$ & $241-\mathrm{C}-106$ & 15,200 & $S$ & 241-T-201 & 42 & $S$ \\
\hline 241-AX-101 & 14,300 & $\mathrm{~S}$ and $\mathrm{M}$ & $241-\mathrm{C}-107$ & 3,990 & $\mathbf{M}$ & $241-\mathrm{T}-202$ & 34 & $S$ \\
\hline 241-AX-102 & 7,210 & $\mathrm{~S}$ and $\mathrm{M}$ & $241-\mathrm{C}-108$ & 438 & $\mathrm{~S}$ & $241-\mathrm{T}-203$ & 68 & $S$ \\
\hline 241-AX-103 & 3,020 & $S$ & $241-C-109$ & 824 & $S$ & $241-T-204$ & 54 & $S$ \\
\hline 241-AX-104 & 115 & $\mathrm{~S}$ and $\mathrm{E}$ & 241-C-110 & 668 & $S$ & 241-TX-101 & 1,630 & E \\
\hline $241-\mathrm{B}-101$ & 311 & $\mathrm{M}$ & 241-C-111 & 350 & $S$ & 241-TX-102 & 12,900 & $\mathrm{E}$ \\
\hline 241-B-102 & 14 & $\mathbf{M}$ & 241-C-112 & 1,450 & $S$ & 241-TX-103 & 9,130 & $\mathrm{E}$ \\
\hline 241-B-103 & 247 & $S$ & 241-C-201 & 283 & $S$ & $241-\mathrm{TX}-104$ & 475 & $S$ \\
\hline 241-B-104 & 74 & $M$ & $241-\mathrm{C}-202$ & 255 & $S$ & 241-TX-105 & 36,200 & $\mathrm{E}$ \\
\hline 241-B-105 & 1 & $\mathbf{M}$ & $241-C-203$ & 2,330 & $S$ & 241-TX-106 & 20,200 & $E$ \\
\hline 241-B-106 & 1,010 & $\mathrm{~S}$ & 241-C-204 & 2,320 & $S$ & 241-TX-107 & 1,750 & $E$ \\
\hline 241-B-107 & 408 & $\mathrm{E}$ & 241-S-101 & 5,160 & $S$ & 241-TX-108 & 7,610 & $\mathrm{E}$ \\
\hline 241-B-108 & 232 & $\mathrm{~S}$ and $\mathrm{E}$ & $241-S-102$ & 13,600 & $S$ and $E$ & 241-TX-109 & 1,700 & $\mathrm{E}$ \\
\hline $241-B-109$ & 1,050 & $S$ & $241-S-103$ & 8,660 & E & $241-\mathrm{TX}-110$ & 25,400 & E \\
\hline 241-B-110 & 477 & $S$ & $241-S-104$ & 3,160 & $S$ & 241-TX-111 & 19,600 & $\mathrm{E}$ \\
\hline 241-B-111 & 93 & $S$ & $241-S-105$ & 25,100 & E & 241-TX-112 & 37,000 & $E$ \\
\hline $241-\mathrm{B}-112$ & 99 & $\mathrm{E}$ & $241-S-106$ & 6,110 & $S$ & 241-TX-113 & 25,900 & E \\
\hline $241-\mathrm{B}-201$ & 325 & $S$ & $24 \mathrm{~J}-\mathrm{S}-107$ & 4,150 & $S$ & 241-TX-114 & 28,000 & E \\
\hline 241-B-202 & 346 & $S$ & $241-S-108$ & 27,200 & $\mathrm{E}$ & 241-TX-115 & 33,700 & $E$ \\
\hline
\end{tabular}




\section{RPP-6664 REV 0}

Table 2-1. Best Basis Inventory of Organic Carbon Content in Single-Shell Tanks from 1998. (2 sheets)

\begin{tabular}{|c|c|c|c|c|c|c|c|c|}
\hline Tank & $\begin{array}{l}\text { Toc } \\
\text { (kg) }\end{array}$ & Basis* & Tank & $\begin{array}{l}\text { TOC } \\
(\mathbf{k g})\end{array}$ & Basis* & Tank & $\begin{array}{l}\text { Toc } \\
(\mathrm{kg})\end{array}$ & Basis* \\
\hline 241-B-203 & 4,830 & $\mathrm{M}$ & 241-S-109 & 1,510 & $\mathrm{E}$ & 241-TX-116 & 2,870 & $M$ \\
\hline 241-B-204 & 4,730 & $\mathrm{M}$ & $241-S-110$ & 6,960 & $\mathrm{~S}$ and $\mathrm{E}$ & 241-TX-117 & 23,700 & $E$ \\
\hline 241-BX-101 & 1,450 & $\mathrm{E}$ & $241-S-111$ & 4,760 & $S$ & 241-TX-118 & 15,400 & $\mathrm{E}$ \\
\hline 241-BX-102 & 498 & $\mathrm{E}$ & $241-S-112$ & 28,600 & $\mathrm{E}$ & 241-TY-101 & 486 & $S$ \\
\hline 241-BX-103 & 1,200 & $\mathrm{E}$ & 241-SX-101 & 3,210 & $S$ & 241-TY-102 & 149 & $S$ \\
\hline 241-BX-104 & 3,380 & $S$ & 241-SX-102 & 10,900 & $S$ & 241-TY-103 & 1,150 & $S$ \\
\hline $241-\mathrm{BX}-105$ & 997 & $S$ & 241-SX-103 & 13,600 & $S$ & 241-TY-104 & 567 & $S$ \\
\hline 241-BX-106 & 656 & $\mathrm{E}$ & $241-S X-104$ & 28,000 & $\mathbf{E}$ & 241-TY-105 & 1,080 & $S$ \\
\hline 241-BX-107 & 1,500 & $S$ & 241-SX-105 & 9,900 & $S$ & 241-TY-106 & 201 & $S$ \\
\hline 241-BX-108 & 80 & $\mathrm{E}$ & 241-SX-106 & 9,920 & $S$ & $241-U-101$ & 255 & $S$ \\
\hline 241-BX-109 & 449 & $S$ & 241-SX-107 & 695 & $E$ & $241-U-102$ & 16,400 & $S$ and $E$ \\
\hline $241-B X-110$ & 1,680 & $S$ and $E$ & 241-SX-108 & 0 & $M$ & $241-U-103$ & 24,300 & $S$ \\
\hline 241-BX-111 & 1,000 & $\mathrm{~S}$ and $\mathrm{E}$ & 241-SX-109 & 853 & $\mathrm{E}$ & 241-U-104 & 3,010 & $\mathrm{E}$ \\
\hline $241-\mathrm{BX}-112$ & 780 & $S$ & 241-SX-110 & 719 & $\mathrm{E}$ & 241-U-105 & 30,000 & $S$ \\
\hline 241-BY-101 & 12,300 & $\mathrm{E}$ & 241-SX-111 & 1,420 & $\mathrm{E}$ & 241-U-106 & 29,600 & $S$ \\
\hline 241-BY-102 & 6,930 & $S$ & 241-SX-112 & 1,050 & $\mathrm{E}$ & 241-U-107 & 4,820 & $\mathrm{E}$ \\
\hline 241-BY-103 & 9,960 & $\mathrm{E}$ & 241-SX-113 & 23 & $\mathrm{E}$ & 241-U-108 & 12,900 & $S$ \\
\hline 241-BY-104 & 14,700 & $S$ & 241-SX-114 & 1,610 & $\mathrm{E}$ & 241-U-109 & 9,730 & $S$ \\
\hline 241-BY-105 & 24,200 & $\mathrm{E}$ & 241-SX-115 & 88 & $\mathrm{~S}$ and $\mathrm{E}$ & 241-U-110 & 982 & $S$ \\
\hline 241-BY-106 & 21,500 & $S$ & 241-T-101 & 235 & $\mathrm{M}$ & 241-U-111 & 9,930 & E \\
\hline 241-BY-107 & 8,400 & $S$ & $241-\mathrm{T}-102$ & 106 & $S$ & $241-\mathrm{U}-112$ & 458 & $\mathrm{E}$ \\
\hline 241-BY-108 & 5,820 & $S$ & 241-T-103 & 57 & $\mathrm{M}$ & 241-U-201 & 27 & $\mathrm{E}$ \\
\hline 241-BY-109 & 11,900 & $S$ & 241-T-104 & 1,520 & $S$ & 241-U-202 & 27 & $\mathrm{E}$ \\
\hline 241-BY-110 & 16,700 & $S$ & 241-T-105 & 1,890 & $S$ & $241-U-203$ & 14 & $E$ \\
\hline 241-BY-111 & 16,700 & $\mathrm{~S}$ & 241-T-106 & 47 & $\mathrm{E}$ & 241-U-204 & 5 & $\mathrm{~S}$ \\
\hline 241-BY-112 & 13,600 & $S$ & $241-T-107$ & 1,680 & $S$ & & & \\
\hline
\end{tabular}

*The notations S, E, and M indicate sample-based, engineering-based, and model-based inventory values.

$\mathrm{TOC}=$ total organic carbon. 


\section{RPP-6664 REV 0}

Table 2-2. Best Basis Inventory of Organic Carbon Content in Double-Shell Tanks from 1998.

\begin{tabular}{|c|c|c|c|c|c|c|c|c|}
\hline Tank & $\begin{array}{l}\text { roc } \\
(\mathbf{k g})\end{array}$ & Basis* & Tank & $\begin{array}{l}\text { TOC } \\
(\mathbf{k g})\end{array}$ & Basis* & Tank & $\begin{array}{l}\text { TOC } \\
(\mathbf{k g})\end{array}$ & Basis* \\
\hline 241-AN-101 & 1,160 & $S$ & 241-AP-105 & 8,130 & $S$ and $E$ & 241-AY-101 & 31,200 & $\mathrm{~S}$ \\
\hline 241-AN-102 & 107,000 & $S$ & 241-AP-106 & 1,740 & $\mathrm{~S}$ and $\mathrm{E}$ & 241-AY-102 & 9,160 & $S$ \\
\hline 241-AN-103 & 12,000 & $\mathrm{~S}$ & 241-AP-107 & 26 & $S$ & 241-AZ-101 & 6,060 & $S$ \\
\hline 241-AN-104 & 19,800 & $S$ & 241-AP-108 & 3,650 & $S$ and $E$ & 241-AZ-102 & 6,220 & $\mathrm{~S}$ and $\mathrm{E}$ \\
\hline 241-AN-105 & 30,000 & $S$ & 241-AW-101 & 18,100 & $S$ & 241-SY-101 & 103,000 & $S$ \\
\hline 241-AN-106 & 649 & $S$ & 241-AW-102 & 1,030 & $S$ & 241-SY-102 & 4,080 & $S$ \\
\hline 241-AN-107 & 161,000 & $S$ & 241-AW-103 & 10,900 & $S$ & 241-SY-103 & 37,900 & $S$ \\
\hline 241-AP-101 & 13,600 & $\mathrm{~S}$ and $\mathrm{E}$ & 241-AW-104 & 20,800 & $S$ & & & \\
\hline 241-AP-102 & 13,700 & $\mathrm{~S}$ & 241-AW-105 & 7,900 & $S$ & & & \\
\hline 241-AP-103 & 10 & $S$ & 241-AW-106 & 3,490 & $S$ & & & \\
\hline 241-AP-104 & 12 & $S$ & 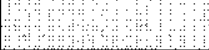 & & & & & \\
\hline
\end{tabular}

*The notations $\mathrm{S}$ and $\mathrm{E}$ indicate sample-based and engineering-based inventory values.

$\mathrm{TOC}=$ total organic content.

Early work (Delegard 1980,1987) implied that new organic compounds derived from the original organic substances were being formed and were accumulating in the waste tanks. This suggestion was confirmed by subsequent work that demonstrated the presence of new substances such as iminodiacetate ion (IDA) $-\mathrm{NH}\left(\mathrm{CH}_{2} \mathrm{CO}_{2}\right)_{2}$ - and oxidized compounds such as formate ion, neither of which had been employed in waste processing operations (Campbell et al. 1994). These results strongly suggested that the organic constituents were being oxidized under the influence of the radiation field. Other investigations carried out to resolve the ferrocyanide safety issue revealed that formate ion, the expected hydrolysis product of cyanide ion $\mathrm{CN}+2 \mathrm{H}_{2} \mathrm{O} \rightarrow \mathrm{HCO}_{2}^{-}+\mathrm{NH}_{3}$ - was absent from the ferrocyanide ion wastes (Lilga et al. 1996). This finding implied that formate ion had decomposed either during storage or during high-temperature evaporation campaigns.

Subsequent speciation of the organic complexants in selected samples of aged wastes from the condensed phases of single- and double-shell tanks and the comparison of the TOC and oxalate ion contents in more than 70 tanks confirm that the organic complexants are being oxidized. Related work on the speciation of the organic solvents in the dome spaces of 110 tanks and in some condensed samples shows the solvents are also oxidized. This information is discussed in the following sections.

\subsubsection{Organic Complexant Species in Solid and Liquid Samples from Single-Shell and Double-Shell Tanks}

The organic compounds in the wastes have been identified by gas and liquid chromatography, mass spectrometry, and other advanced analytical methods (Campbell et al. 1994, 1995a, 1995b, 1996a, 1996b, 1997, 1998; Pool and Bean 1994; Wahl et al. 1995). The presence of many new 
substances in addition to the original complexants and solvents has been rigorously established in these investigations. The new anions detected in broadly ranging qualitative investigations include the fragmentation products of EDTA and HEDTA, including ethylenediaminetriacetate (ED3A), two isomers of ethylenediaminediacetate (s-EDDA and $\mathrm{u}$-EDDA), and ethylenediaminemonoacetate, as well as NTA, IDA, glycinate, acetate, formate and oxalate ions.

Ethylenediaminetriacetate ion (ED3A): $\left({ }^{-} \mathrm{O}_{2} \mathrm{CCH}_{2}\right)_{2} \mathrm{NCH}_{2} \mathrm{CH}_{2} \mathrm{NH}\left(\mathrm{CH}_{2} \mathrm{CO}_{2}{ }^{-}\right)$

s-Ethylenediaminediacetate ion (s-EDDA): $\left(\mathrm{O}_{2} \mathrm{CCH}_{2}\right) \mathrm{NHCH}_{2} \mathrm{CH}_{2} \mathrm{NH}\left(\mathrm{CH}_{2} \mathrm{CO}_{2}{ }^{-}\right)$

$\mathrm{u}$-Ethylenediaminediacetate ion (u-EDDA): $\left(\mathrm{O}_{2} \mathrm{CCH}_{2}\right)_{2} \mathrm{NCH}_{2} \mathrm{CH}_{2} \mathrm{NH}_{2}$

Ethylenediaminemonoacetate ion: $\left(\mathrm{O}_{2} \mathrm{CCH}_{2}\right) \mathrm{NHCH}_{2} \mathrm{CH}_{2} \mathrm{NH}_{2}$

The concentrations of the original complexants and their principal oxidation products have been determined in the laboratories at the Hanford Site and the Pacific Northwest National Laboratory for samples from more than 20 single-shell and double-shell tanks (Campbell et al. 1994, 1995a, 1995b, 1996a, 1996b, 1997, 1998; Pool and Bean 1994; Wahl et al. 1995). The results compiled by Meacham and Camaioni et al. (Meacham et al. 1998; Camaioni et al. 1998) for single-shell tanks are summarized in Table 2-3. The related observations for the double-shell tanks are shown in Table 2-4. The concentrations of acetate, formate, and oxalate ion have been determined for cores from three double-shell tanks. These results are shown in Table 2-5.

Table 2-3. Concentrations of Organic Species in Weight Percent (Wet) for Samples from Single-Shell Tanks. (2 sheets)

\begin{tabular}{|c|c|c|c|c|c|c|c|c|c|c|}
\hline Tank (Sample) & $\begin{array}{c}\text { Acetate } \\
\text { (wt\%) }\end{array}$ & $\begin{array}{l}\text { Citrate } \\
(w t \%)\end{array}$ & $\begin{array}{l}\text { Glycolate } \\
(\mathrm{wt} \%)\end{array}$ & Formate & $\begin{array}{l}\text { Oxalate } \\
(w+\%)\end{array}$ & $\begin{array}{l}\text { EDTA } \\
(w t \%)\end{array}$ & HEDTA & (wt \%) & $\begin{array}{l}\text { NTA } \\
(w t \%)\end{array}$ & $\begin{array}{c}\text { TOC } \\
(\mathrm{wt} \%)\end{array}$ \\
\hline \begin{tabular}{|l|}
$241-\mathrm{A}-101$ \\
$(\mathrm{C} 154, \mathrm{~S} 10, \mathrm{UH})$ \\
\end{tabular} & 0.21 & & & 0.27 & 3.80 & 0.19 & & 1.20 & & \\
\hline \begin{tabular}{|l|}
$241-\mathrm{A}-102(96-\mathrm{A}$ \\
UG-3)
\end{tabular} & 0.18 & 0.13 & & 0.17 & 1.40 & & & & & 1.00 \\
\hline $\begin{array}{l}241-A X-102 \\
\text { (95-AUG-007) }\end{array}$ & & 0.51 & 0.77 & 0.48 & 1.80 & 0.30 & 0.15 & 1.20 & & 3.50 \\
\hline \begin{tabular}{|l|}
$241-\mathrm{B}-106$ \\
$(\mathrm{C} 93, \mathrm{~S} 1, \mathrm{UH})$
\end{tabular} & 0.00 & & & 0.01 & & & & & & 0.20 \\
\hline $\begin{array}{l}241-B Y-102 \\
(\mathrm{C} 157, \mathrm{~S} 4)\end{array}$ & 0.01 & & & 0.00 & 6.80 & & & & & 1.90 \\
\hline \begin{tabular}{|l|}
$241-B Y-104$ \\
(C116, SLG)
\end{tabular} & & 3.00 & & & 5.40 & & & & & 1.80 \\
\hline $\begin{array}{l}241-\mathrm{BY}-105 \\
\text { (C108, S1, DL) }\end{array}$ & 0.11 & 0.21 & & 0.09 & & & & & & 0.18 \\
\hline $\begin{array}{l}241-B Y-107 \\
(\mathrm{C} 161, \mathrm{~S} 1) \\
\end{array}$ & 0.14 & & & 0.06 & 2.60 & & & & & 0.88 \\
\hline $\begin{array}{l}241-\mathrm{BY}-110 \\
(\mathrm{C} 101, \mathrm{~S} 7) \\
\end{array}$ & 0.09 & & & 0.04 & 9.50 & & & & & 2.10 \\
\hline \begin{tabular}{|l|}
$241-\mathrm{BY}-110$ \\
$(\mathrm{C} 103, \mathrm{~S} 4, \mathrm{UH})$
\end{tabular} & 0.05 & & & & 3.70 & & & & & 0.75 \\
\hline
\end{tabular}




\section{RPP-6664 REV 0}

Table 2-3. Concentrations of Organic Species in Weight Percent (Wet) for Samples from Single-Shell Tanks. (2 sheets)

\begin{tabular}{|c|c|c|c|c|c|c|c|c|c|c|}
\hline Tank (Sample) & $\begin{array}{l}\text { Acetate } \\
(\mathrm{wt} \%)\end{array}$ & $\begin{array}{l}\text { Citrate } \\
(\text { wt \%) }\end{array}$ & $\begin{array}{l}\text { Glycolate } \\
\text { (wt \%) }\end{array}$ & $\begin{array}{c}\begin{array}{c}\text { Formate } \\
(w t \%)\end{array} \\
\end{array}$ & $\begin{array}{l}\text { Oxalate } \\
\text { (wt\%) }\end{array}$ & $\begin{array}{l}\text { EDTA } \\
(\text { wt \%) }\end{array}$ & $\begin{array}{l}\text { HEDTA } \\
(\mathrm{wt} \%)\end{array}$ & $\begin{array}{l}\text { DA } \\
(\mathbf{w t} \%)\end{array}$ & $\begin{array}{r}\text { NTA } \\
(\mathbf{w t} \%)\end{array}$ & $\begin{array}{r}\text { TOC } \\
(w t \%)\end{array}$ \\
\hline $\begin{array}{l}241-\mathrm{BY}-110 \\
(\mathrm{C} 113, \mathrm{~S} 8)\end{array}$ & 0.07 & & & 0.01 & 0.04 & & & & & 0.21 \\
\hline $\begin{array}{l}241-\mathrm{C}-104 \\
\text { (C162, S2, UH) }\end{array}$ & 0.25 & & & 0.19 & 0.23 & & & & & 0.91 \\
\hline $\begin{array}{l}241-\mathrm{C}-105 \\
\text { (C76, S1, SLG) }\end{array}$ & 0.23 & 0.39 & & 0.05 & 0.05 & & & & 0.10 & 0.35 \\
\hline \begin{tabular}{|l|}
$241-\mathrm{C}-201$ \\
(TANK COMP) \\
\end{tabular} & 0.10 & & & 0.02 & 3.70 & & & & 0.11 & \\
\hline $\begin{array}{l}241-\mathrm{U}-105 \\
\text { (C136, S7, UH) }\end{array}$ & 0.07 & 0.39 & 0.40 & 0.72 & 0.83 & 0.40 & 0.54 & & & 2.20 \\
\hline $\begin{array}{l}241-\mathrm{U}-106 \\
\text { (C148, S2, UH) }\end{array}$ & 0.04 & 0.59 & 0.45 & 0.27 & 0.48 & 0.63 & 0.67 & & & 2.40 \\
\hline $\begin{array}{l}241-U-107 \\
\text { (C134, SLG) }\end{array}$ & 0.04 & 0.09 & & 0.12 & 0.24 & & & & & 0.15 \\
\hline $\begin{array}{l}\text { 241-U-108 } \\
\text { (C141, S4, UH) }\end{array}$ & 0.06 & & 0.16 & 0.18 & 0.50 & 0.10 & 0.03 & 0.16 & & 0.63 \\
\hline
\end{tabular}

Note: Information is this table is from

- D. M. Camaioni, W. D. Samuels, J. C. Lenihan, S. T. Sharma, A. K. Autrey, M. A. Lilga, M. O. Hogan, S. A. Clauss, K. L. Wahl, and J. A. Campbell, 1998, Organic Tanks Safety Program Waste Aging Studies Final Report, PNNL-11909, Pacific Northwest National Laboratory, Richland, Washington

- J. E. Meacham, W. L. Cowley, A. B. Webb, N. W. Kirch, J. A. Lechelt, D. A. Reynolds, L. A. Stauffer, D. M. Camaioni, F. Gao, R. T. Hallen, P. G. Hessler, J. L. Huckaby, R. D. Scheele, C. S. Simmons, J. J. Toth, D. B. Bechtold, and L. M. Stock, 1998, Organic Complexant Topical Report, HNF-SW-CN-058, Rev. 0, Duke Engineering Services Hanford, Inc., Richland, Washington.

*The tank, core number or sample type, segment number, and other details are shown:

$\mathrm{AUG}=$ auger.

COMP $=$ composite.

$\mathrm{DL}=$ drainable liquid.
$\mathrm{LH}=$ lower half.

SLG = sludge.

$\mathrm{UH}=$ upper half. 
Table 2-4. Concentrations of Organic Species in Weight Percent (Wet) for Samples from Double-Shell Tanks.

\begin{tabular}{|c|c|c|c|c|c|c|c|c|c|c|c|}
\hline Tank (Sample*) & $\begin{array}{l}\text { Acetate } \\
(\text { wt \% })\end{array}$ & $\begin{array}{l}\text { Citrate } \\
\text { (wt \%) }\end{array}$ & $\begin{array}{c}\text { Glycolate } \\
(\text { wt \% })\end{array}$ & $\begin{array}{l}\text { Formate } \\
\text { (wt \%) }\end{array}$ & $\begin{array}{l}\text { Oxalate } \\
\text { (wt \%) }\end{array}$ & $\begin{array}{l}\text { EDTA } \\
(\mathbf{w} \%)\end{array}$ & ED3A & HEDTA & (wt\%) & $\begin{array}{l}\text { NTA } \\
(w t \%)\end{array}$ & $\begin{array}{l}\text { Toc } \\
(w t \%)\end{array}$ \\
\hline \begin{tabular}{|l|}
$241-\mathrm{AW}-101$ \\
$(\mathrm{C} 154, \mathrm{~S} 10, \mathrm{UH})$
\end{tabular} & 0.93 & 0.02 & 0.05 & 0.10 & 1.10 & & & & & 0.01 & 1.50 \\
\hline \begin{tabular}{|l|}
$241-\mathrm{AN}-107$ \\
(Grab) \\
\end{tabular} & & 0.49 & 0.94 & 0.45 & 1.40 & 0.20 & 0.29 & 0.04 & 0.33 & 0.04 & 1.00 \\
\hline $\begin{array}{l}241-S Y-101 \\
\text { (Convective) }\end{array}$ & 0.20 & 0.08 & 0.17 & 0.51 & 0.65 & 0.53 & 0.73 & & 0.28 & 0.09 & 3.50 \\
\hline $\begin{array}{l}\text { 241-SY-101 } \\
\text { (Nonconvective) }\end{array}$ & & 0.08 & & 0.23 & 2.10 & 0.19 & 0.07 & & 0.22 & 0.06 & 0.20 \\
\hline \begin{tabular}{|l|}
$241-S Y-103$ \\
(Convective)
\end{tabular} & 0.15 & 0.11 & & 0.45 & & 0.13 & 0.06 & & 0.06 & 0.04 & 1.90 \\
\hline $\begin{array}{l}241-S Y-103 \\
\text { (Nonconvective) }\end{array}$ & 0.17 & 0.15 & & 0.34 & 2.20 & 0.16 & 0.04 & & 0.04 & 0.04 & 1.80 \\
\hline
\end{tabular}

Note: Information in this table is from J. E. Meacham, W. L. Cowley, A. B. Webb, N. W. Kirch, J. A. Lechelt, D. A. Reynolds, L. A. Stauffer, D. M. Camaioni, F. Gao, R. T. Hallen, P. G. Hessler, J. L. Huckaby, R. D. Scheele, C. S. Simmons, J. J. Toth, D. B. Bechtold, and L. M. Stock, 1998, Organic Complexant Topical Report, HNF-SD-CN-058, Rev. 0, Duke Engineering Services Hanford, Inc., Richland, Washington.

*The tank, core number or sample type, segment number, and other details are shown:

\begin{tabular}{|c|c|c|c|}
\hline $\begin{array}{l}\text { ED3A } \\
\text { EDTA }\end{array}$ & $\begin{array}{l}=\text { ethylenediaminetriacetate ion. } \\
=\text { ethylenediaminetetraacetate ion }\end{array}$ & $\begin{array}{l}\text { NTA } \\
\text { TOC }\end{array}$ & $\begin{array}{l}=\text { nitrilotriacetate ion. } \\
=\text { total organic carbon. }\end{array}$ \\
\hline $\begin{array}{l}\text { HEDTA } \\
\text { IDA }\end{array}$ & $\begin{array}{l}=\text { hydroxyethylethylenediaminetriacetate ion. } \\
=\text { iminodiacetate ion. }\end{array}$ & UH & $=$ upper half. \\
\hline
\end{tabular}

Table 2-5. Inventory of Acetate, Formate, and Oxalate Ions Determined by Analysis of Cores from Double-Shell Tanks. (2 sheets)

\begin{tabular}{|c|c|c|c|c|}
\hline Tank & $\begin{array}{c}\text { Acetate } \\
\text { (kg) }\end{array}$ & $\begin{array}{l}\text { Formate } \\
\text { (kg) }\end{array}$ & $\begin{array}{c}\text { Oxalate } \\
(\mathbf{k g})\end{array}$ & $\begin{array}{l}\text { TOC } \\
(\mathrm{kg})\end{array}$ \\
\hline \multicolumn{5}{|l|}{ 241-AN-103 } \\
\hline Crust & 290 & 210 & 2,100 & 650 \\
\hline Nonconvective layer & 1,400 & 0 & 27,000 & 6,200 \\
\hline Convective layer & 5,400 & 0 & & 5,800 \\
\hline Total & 7,100 & 0 & 29,000 & 13,000 \\
\hline Percentage of carbon in TOC & 23 & 14 & 62 & \\
\hline
\end{tabular}


Table 2-5. Inventory of Acetate, Formate, and Oxalate Ions Determined by Analysis of Cores from Double-Shell Tanks. (2 sheets)

\begin{tabular}{|c|c|c|c|c|}
\hline Tank & $\begin{array}{c}\text { Acetate } \\
\text { (kg) }\end{array}$ & $\begin{array}{l}\text { Formate } \\
\text { (kg) }\end{array}$ & $\begin{array}{l}\text { Oxalate } \\
\text { (kg) }\end{array}$ & $\begin{array}{l}\text { TOC } \\
\text { (kg) }\end{array}$ \\
\hline \multicolumn{5}{|l|}{ 241-AN-104 } \\
\hline Crust & 12 & 19 & 240 & 150 \\
\hline Nonconvective layer & 1,600 & 1,900 & 25,000 & 12,000 \\
\hline Convective layer & 4,300 & 7,800 & & 7,100 \\
\hline Total & 5,900 & 9,700 & 25,000 & 19,000 \\
\hline Percentage of carbon in TOC & 13 & 14 & 36 & \\
\hline & & & H & \\
\hline \multicolumn{5}{|l|}{ 241-AN-105 } \\
\hline Supernatant & 1,600 & 4,200 & & 16,000 \\
\hline Salt slurry & 1,700 & 2,800 & 19,000 & 13,000 \\
\hline Total & 3,300 & 7,000 & 19,000 & 29,000 \\
\hline Percentage of carbon in TOC & 5 & 7 & 18 & \\
\hline
\end{tabular}

Note: The analytical information is presented in the characterization reports for the three tanks.

$\mathrm{TOC}=$ total organic carbon.

The analyses of the wastes in the single-shell tanks indicate the original four complexants have been converted into a broad array of other organic compounds (see Table 2-3). The most highly oxidized organic compounds, formate and oxalate ion, are abundant in these samples. The results for the single-shell tanks also show that glycolate ion, the most abundant original complexant, is absent from many waste samples and when present, its concentration is usually much less than the concentration of oxalate ion. Citrate ion is distributed in essentially the same way. The EDTA and HEDTA concentrations are below the detection limit in most samples. However, their remnants, IDA and NTA, are detectable in some wastes even though their precursors have been consumed.

The original organic complexants are absent from some wastes (for example, tanks 241-BY-102 and 241-BY-110) even though the TOC content is relatively high. Oxalate ion is the most abundant organic constituent in these wastes. In contrast, the original complexants are still present in readily measured concentrations in wastes from tanks 241-U-105 and 241-U-106. The results indicate that the oxidation reaction has not proceeded to the same extent in the wastes obtained from the BY and $\mathrm{U}$ tanks. The differences arise from differences in the thermal history of the wastes. The wastes discharged to tanks $241-\mathrm{U}-105$ and $241-\mathrm{U}-106$ were processed and stored at much lower temperatures than the wastes evaporated at high temperature and discharged to tanks 241-BY-102 and 241-BY-110. The temperature history of the waste and the storage temperature can have a pronounced effect on the current organic content, one of the key variables dictating the rate of gas formation.

The distributions of the organic constituents in the samples from the double-shell tanks (see Table 2-4) are comparable with the results for the single-shell tanks. The remnant molecules of 


\section{RPP-6664 REV 0}

the EDTA family are readily discernible in the samples from some double-shell tanks, and the concentrations of the low molecular weight organic carboxylate ions are high. In addition, there is a significant difference in the concentrations of sodium oxalate in the convective and nonconvective layers. This compound accumulates in the solid phases of the waste because of its low solubility in solutions with very high concentrations of other soluble sodium salts (Barney 1995).

The acetate, formate, and oxalate ion concentrations have been determined in characterization work on cores from tanks 241-AN-103, 241-AN-104 and 241-AN-105. The inventories for these substances projected from the analytical results imply that these three compounds account for $98 \%, 62 \%$ and $30 \%$ (respectively) of the TOC in these tanks (see Table 2-5). These results, like the results in Tables 2-3 and 2-4, provide additional evidence that the concentrations of the original organic complexants have decreased as they have been degraded and oxidized.

In summary, the detailed speciation work on samples representative of many different wastes in single- and double-shell tanks indicates the organic complexants have been oxidized and fragmented and provides substantive evidence for ongoing step-by-step oxidation reactions that will eventually convert the organic constituents into carbonate ion.

\subsubsection{Oxalate Ion Content of Solid and Liquid Samples from Single-Shell and Double- Shell Tanks}

Oxalate ion concentrations can be readily determined by ion chromatography, an analytical measurement routinely performed on waste to determine the concentrations of the major inorganic anions. The oxalate ion and TOC contents of the tanks for which data are available are examined in this section to establish the general occurrence of oxidation.

The TOC and oxalate contents of more than 50 single-shell tanks have been measured. The observations for 8 tanks are incomplete and either the TOC or the oxalate ion inventory could not be assessed from the sampling data. The results for 13 other tanks indicate that the TOC and oxalate concentrations are less than $0.1 \mathrm{wt} \%$ (wet basis). These data are not useful for assessing the progress of the oxidation reaction. The observations for 32 single-shell tanks for which reliable information is available are summarized in Table 2-6.

The sample-based mean TOC concentrations and TOC inventories are shown in the second and third columns of Table 2-6. The sample-based oxalate ion inventories and the average percentage of organic carbon in the form of oxalate ion are tabulated in the fourth and fifth columns. The standard deviations for the TOC and oxalate analyses provided in the characterization reports were used to estimate the standard deviation in the percentage of organic carbon in oxalate.

Seven of the 32 tanks shown in Table 2-6 had oxalate concentrations sufficient to account for more than 75\% of the TOC (tanks 241-BY-102, 241-BY-103, 241-BY-105, 241-241-BY-107, 241-BY-109, 241-BY-111, and 241-BY-112). Ten tanks had oxalate concentrations sufficient to account for $50 \%$ to $75 \%$ of the measured TOC (tanks 241-BX-110, 241-BY-101, 241-BY-104, 241-BY-106, 241-S-101, 241-S-102, 241-S-106, 241-S-107, 241-S-111, and 241-SX-101). 


\section{RPP-6664 REV 0}

Fifteen tanks had oxalate concentrations sufficient to account for $10 \%$ to $50 \%$ of the TOC (tanks 241-A-101, 241-A-102, 241-AX-101, 241-AX-102, 241-AX-103, 241-BY-108, 241-BY-110, 241-C-104, 241-SX-106, 241-U-102, 241-U-103, 241-U-105, 241-U-106, 241-U-107, and 241-U-108).

Table 2-6. Organic Carbon and Oxalate Ion Contents for Single-Shell Tanks. (2 sheets)

\begin{tabular}{|c|c|c|c|c|}
\hline Tank & $\begin{array}{l}\text { Mean TOC } \\
\text { (wt\%, wet) }\end{array}$ & TOC Inventory $_{(\mathbf{k g})}$ & $\begin{array}{c}\text { Oxalate } \\
\text { Inventory } \\
\text { (kg) }\end{array}$ & $\begin{array}{c}\text { TOC as Oxalate } \\
(w+\%)(s d)\end{array}$ \\
\hline 241-A-101 & 0.31 & 19,600 & 31,300 & $44(7)$ \\
\hline $241-A-102$ & 1.11 & 3,910 & 3,140 & $22(2)$ \\
\hline 241-AX-101 & 0.62 & 3,050 & 4,250 & $38(33)$ \\
\hline 241-AX-102 & 1.87 & 3,290 & 1,450 & $12(1)$ \\
\hline 241-AX-103 & 0.52 & 3,260 & 5,130 & $43(2)$ \\
\hline $241-\mathrm{BX}-110$ & 0.15 & 2,070 & 4,710 & $62(34)$ \\
\hline 241-BY-101 & 0.48 & 12,300 & 33,400 & $74(\mathrm{~N} / \mathrm{A})$ \\
\hline 241-BY-102 & 0.38 & 6,940 & 30,400 & $>99(33)$ \\
\hline 241-BY-103 & 0.38 & 9,960 & 36,500 & $99(25)$ \\
\hline 241-BY-104 & 0.67 & 6,810 & 13,100 & $52(51)$ \\
\hline 241-BY-105 & 0.73 & 24,200 & 84,300 & $95(52)$ \\
\hline 241-BY-106 & 0.51 & 21,500 & 59,000 & $75(15)$ \\
\hline 241-BY-107 & 0.52 & 7,630 & 22,000 & $79(19)$ \\
\hline 241-BY-108 & 0.39 & 5,820 & 9,750 & $46(11)$ \\
\hline 241-BY-109 & 0.33 & 11,900 & 37,100 & $85(70)$ \\
\hline 241-BY-110 & 0.64 & 16,700 & 26,300 & $43(11)$ \\
\hline 241-BY-111 & 0.55 & 16,700 & 52,800 & $86(33)$ \\
\hline 241-BY-112 & 0.71 & 13,600 & 47,700 & $96(44)$ \\
\hline 241-C-104 & 1.00 & 16,100 & 6,390 & $11(4)$ \\
\hline $241-S-101$ & 0.22 & 5,160 & 10,200 & $52(38)$ \\
\hline $241-S-102$ & 0.33 & 11,800 & 25,400 & $57(17)$ \\
\hline $241-S-106$ & 0.23 & 6,110 & 13,000 & $58(16)$ \\
\hline $241-S-107$ & 0.20 & 4,150 & 10,200 & $67(11)$ \\
\hline $241-S-111$ & 0.17 & 6,600 & 17,300 & $71(19)$ \\
\hline 241-SX-101 & 0.53 & 15,800 & 32,400 & $56(41)$ \\
\hline 241-SX-106 & 0.39 & 13,300 & 17,600 & $36(39)$ \\
\hline $241-\mathrm{U}-102$ & 0.74 & 15,900 & 10,300 & $18(3)$ \\
\hline $241-U-103$ & 0.64 & 24,000 & 7,690 & $9(2)$ \\
\hline $241-\mathrm{U}-105$ & 1.23 & 31,200 & 24,100 & $22(3)$ \\
\hline $241-U-106$ & 2.16 & 29,600 & 12,700 & $12(2)$ \\
\hline
\end{tabular}


Table 2-6. Organic Carbon and Oxalate Ion Contents for Single-Shell Tanks. (2 sheets)

\begin{tabular}{|c|c|c|c|c|}
\hline Tank & $\begin{array}{l}\text { Mean TOC } \\
\left(w \%, w^{\circ}\right)\end{array}$ & TOC Inventory ${ }_{(\mathrm{kg})}$ & $\begin{array}{c}\text { Oxalate, } \\
\text { Inventory? } \\
(\mathbf{k g})\end{array}$ & $\begin{array}{c}\text { ToC as Oxalate } \mathrm{de} \\
(\text { wt } \%)(\mathrm{sd})\end{array}$ \\
\hline 241-U-107 & 0.18 & 4,950 & 6,860 & $38(16)$ \\
\hline 241-U-108 & 0.42 & 12,900 & 12,700 & $27(3)$ \\
\hline
\end{tabular}

Note: Information in this table is from J. E. Meacham, W. L. Cowley, A. B. Webb, N. W. Kirch,

J. A. Lechelt, D. A. Reynolds, L. A. Stauffer, D. M. Camaioni, F. Gao, R. T. Hallen, P. G. Hessler, J. L. Huckaby, R. D. Scheele, C. S. Simmons, J. J. Toth, D. B. Bechtold, and L. M. Stock, 1998, Organic Complexant Topical Report, HNF-SD- WM-CN-058, Rev. 0, Duke Engineering Services Hanford, Inc., Richland, Washington.

${ }^{\mathrm{a}} \mathrm{Mean}$ TOC concentration calculated from the best basis inventory and the weight of the waste determined from the volume and the average density.

${ }^{\mathrm{b}} \mathrm{TOC}$ inventory presented in the tank characterization database or the current tank characterization report.

'Oxalate ion inventory evaluated from inventory or sampling data provided in the tank characterization database or current characterization reports.

${ }^{\mathrm{d} A v e r a g e ~ p e r c e n t a g e ~ o f ~ c a r b o n ~ a s ~ o x a l a t e ~ e v a l u a t e d ~ f r o m ~ i n v e n t o r y ~ a n d ~ s a m p l i n g ~ d a t a . ~}$

${ }^{\mathrm{e}}$ Uncertainty is calculated using the following expression:

$$
s d=\sqrt{\left(\frac{a}{b}\right)^{2}\left(\frac{\sigma_{a}}{a}\right)^{2}+\left(\frac{b}{a}\right)^{2}\left(\frac{\sigma_{b}}{b}\right)^{2}}
$$

where "sd" is the standard deviation, "a" represents TOC measurements, and "b" represents oxalate measurements.

$\mathrm{N} / \mathrm{A}=$ not available.

TOC $=$ total organic carbon.

The TOC and oxalate ion contents have been measured for 19 double-shell tanks. The observations for 3 tanks are too limited to permit the determination of either the TOC inventory or the oxalate ion inventory, and the results for 3 other tanks revealed the wastes had less than $0.1 \mathrm{wt} \%$ (wet basis) TOC with comparably low oxalate ion contents. The observations for 13 double-shell tanks with more than $0.1 \%$ TOC are summarized in Table 2-7.

Table 2-7. Organic Carbon and Oxalate Ion Contents for Double-Shell Tanks. (2 sheets)

\begin{tabular}{|l|c|c|c|c|c|}
\hline \multirow{2}{*}{$\begin{array}{r}\text { Tank } \\
\text { Note }\end{array}$} & $\begin{array}{c}\text { Mean TOC } \\
(\boldsymbol{\mu g} / \mathbf{m L})\end{array}$ & $\begin{array}{c}\text { TOC Inventory } \\
(\mathbf{k g})\end{array}$ & $\begin{array}{c}\text { Oxalate Inventory } \\
\text { (kg) }\end{array}$ & $\begin{array}{c}\text { TOC as Oxalate* } \\
\text { (wt \%) (sd) }\end{array}$ \\
\hline $241-\mathrm{AN}-103$ & 1 & 3,490 & 12,600 & 28,600 & $62(7)$ \\
\hline $241-\mathrm{AN}-104$ & 1 & 4,780 & 19,100 & 25,100 & $35(5)$ \\
\hline $241-\mathrm{AN}-105$ & 1 & 6,750 & 28,800 & 19,300 & $18(3)$ \\
\hline $241-\mathrm{AP}-102$ & 1 & 3,280 & 13,700 & 3,190 & $6(1)$ \\
\hline $241-\mathrm{AP}-105$ & 2 & 2,790 & 8,130 & 4,130 & $14(\mathrm{~N} / \mathrm{A})$ \\
\hline $241-\mathrm{AP}-108$ & 2 & 1,560 & N/A & N/A & $21(6)$ \\
\hline $241-\mathrm{AW}-101$ & 1 & 3,300 & 14,000 & 2,540 & $5(11)$ \\
\hline $241-\mathrm{AW}-104$ & 2 & 4,800 & N/A & N/A & $27(38)$ \\
\hline $241-\mathrm{AW}-105$ & 2 & 5,100 & N/A & N/A & $8(18)$ \\
\hline $241-\mathrm{AY}-101$ & 1 & 6,770 & 24,000 & 13,800 & $16(2)$ \\
\hline
\end{tabular}




\section{RPP-6664 REV 0}

Table 2-7. Organic Carbon and Oxalate Ion Contents for Double-Shell Tanks. (2 sheets)

\begin{tabular}{|c|c|c|c|c|c|}
\hline Tank & Note & $\begin{array}{l}\text { Mean TOC } \\
(\mu \mathrm{g} / \mathrm{mL})\end{array}$ & $\begin{array}{l}\text { TOC Inventory } \\
\text { (kg) }\end{array}$ & $\begin{array}{c}\text { Oxalate Inventory } \\
\text { (kg) }\end{array}$ & $\begin{array}{l}\text { TOC as Oxalate* } \\
(w \mathrm{t} \%)(\mathrm{sd})\end{array}$ \\
\hline 241-SY-101 & 3 & 25,000 & 104,000 & 92,000 & $24(\mathrm{~N} / \mathrm{A})$ \\
\hline 241-SY-102 & 1 & 1,450 & 4,070 & 10,900 & 73 (N/A) \\
\hline 241-SY-103 & 3 & 12,800 & 36,200 & 44,700 & $34(\mathrm{~N} / \mathrm{A})$ \\
\hline
\end{tabular}

Note 1: Mean concentrations and inventory information adapted from current tank characterization reports.

Note 2: Mean concentrations and percentage of carbon in oxalate ion evaluated from tank characterization reports.

Note 3: Mean concentrations and inventory for TOC evaluated from tank characterization reports, inventory for oxalate ion evaluated from speciation information in Table 2-4.

*Average percentage of carbon as oxalate is evaluated from inventory and sampling data. Uncertainty is calculated using the following expression:

$$
s d=\sqrt{\left(\frac{a}{b}\right)^{2}\left(\frac{\sigma_{a}}{a}\right)^{2}+\left(\frac{b}{a}\right)^{2}\left(\frac{\sigma_{b}}{b}\right)^{2}}
$$

where "sd" is the standard deviation, "a" represents TOC measurements, and " $b$ " represents oxalate measurements.

$\mathrm{N} / \mathrm{A}=$ not available.

TOC $=$ total organic carbon.

The sample-based mean TOC concentrations and TOC inventories are shown in the third and fourth columns of Table 2-7. The sample-based oxalate ion inventories and the average percentage of organic carbon in the form of oxalate ion are tabulated in the fifth and sixth columns. The relative standard deviations for the TOC and oxalate analyses provided in the characterization reports were used to estimate the standard deviation in the percentage of organic carbon in oxalate. For tanks 241-SY-101 and 241-SY-103, the best basis inventory for TOC was adopted, but the oxalate ion inventory was assessed from the oxalate ion analysis provided by speciation reports (Campbell et al. 1994, 1995a, 1995b, 1996a, 1996b, 1997, Wahl et al. 1995).

The results of the statistical evaluations presented in the tank characterization reports for TOC and oxalate ion measurements were used to evaluate the standard deviation in the average percentage of carbon in oxalate value. There is considerable variation in the percentage of carbon in oxalate for the double-shell tanks, with values ranging from 5\% for tank 241-AW-101 to $73 \%$ for $241-\mathrm{SY}-102$. The percentage of carbon in oxalate ion is generally smaller for the double-shell tanks than for the single-shell tanks. Only two of the 13 double-shell tanks for which information is available have more than $50 \%$ of the TOC in the form of oxalate. The tanks with predominantly supernatant liquid, such tanks 241-AP-102, 241-AW-101, and 241-AW-105, have less than $10 \%$ of their organic carbon in oxalate ion. These observations are not unexpected since interim stabilization operations have transferred relatively TOC-rich, oxalate-poor supernatant liquids from the single-shell tanks into the double-shell tanks.

In contrast, the analytical work on the sludges in tanks 241-AN-103 and 241-SY-102 indicate these materials have relatively high concentrations of oxalate ion and organic carbon. As in the single-shell tanks the almost insoluble oxalate ion accumulates in the sludge and saltcake layers of the double-shell tanks (Meacham et al. 1998). Consequently, the projected standard 


\section{RPP-6664 REV 0}

deviations are sometimes large reflecting the necessary comparison of low oxalate ion contents in liquid supernatants with high oxalate ion contents of solid sludges and saltcakes.

In summary, the analytical work concerning the oxalate ion content in the more than 70 tanks shown in Tables 2-6 and 2-7 establishes that oxalate ion, which is less reactive and less soluble than the other oxidation products, is now ubiquitous. The relatively high concentrations of this compound in the waste also indicate the widespread occurrence of oxidation reactions of the organic complexants and solvents.

\subsubsection{Organic Solvent Species in Samples from Single-Shell and Double-Shell Tanks}

Dome space monitoring and the Retained Gas Sampling Program have shown that methane and other hydrocarbon with two to four carbon atoms emerge from the waste (Mahoney et al. 1999, 2000). These substances are byproducts of the oxidative reactions of the organic solvents. The hydrolysis reactions of the phosphate esters and the radiolytic reactions of the solvents are discussed in the organic solvent topical report (Cowley et al. 1998). In brief, the radiolysis of hydrocarbons and phosphate esters yields hydrogen and lesser amounts of gaseous organic hydrocarbons including methane, ethane, propane, butane and the related alkenes, alkadienes, and cycloalkanes (Wilkinson and Williams 1961; Davis 1984; Spinks and Woods 1990; Tabata et al. 1991; Bugaenko et al. 1993). The radiolysis reactions of the solvents in the presence of oxidizing agents yield these substances and other oxidation products including alcohols, aldehydes, and ketones (Spinks and Woods 1990).

The oxidation of the organic solvents in the waste tanks has been verified in several ways. Samples from the dome spaces of approximately 110 single-shell tanks have been analyzed by gas chromatography and mass spectrometry (Huckaby et al.1996; Mahoney et al. 2000). More than 1,200 fragmented and oxidized compounds that are structurally related to the original hydrocarbons and phosphate esters are now present in the wastes. The substances emerging from the organic layer of TBP and NPH in tank 241-C-103 at concentrations greater than $1 \mathrm{mg} / \mathrm{m}^{3}$ are shown in Table 2-8, and the related information for tank 241-C-106, which contained an organic oil rich in sodium bis(2-ethylhexyl)phosphate, is shown in Table 2-9. 
Table 2-8. Organic Compounds at Concentrations Greater Than One Milligram per Cubic Meter in Dome Space of Tank 241-C-103.

\begin{tabular}{|c|c|c|c|c|c|}
\hline Alkanes & $\begin{array}{r}\text { Conc } \\
\left(\mathrm{mg} / \mathrm{m}^{3}\right)\end{array}$ & Cycloalkanes & $\begin{array}{c}\text { Conc. } \\
\left(\mathbf{m g} / \mathbf{m}^{3}\right) \\
\end{array}$ & $\begin{array}{l}\text { Aldehydes } \\
\text { and Ketones }\end{array}$ & $\begin{array}{c}\text { Conc, } \\
\left(\mathrm{mg} / \mathrm{m}^{3}\right) \\
\end{array}$ \\
\hline Butane & 13 & Cyclopentane & & Butanal & 3 \\
\hline Hexane & 3 & One other $\mathrm{C} 12$ cyclopentane & 36 & Nonanal & 2 \\
\hline Heptane & 3 & Cyclohexane & & Propanone & 19 \\
\hline Octane & 1 & Four other $\mathrm{C} 13$ cyclohexanes & 47 & 2-Butanone & 27 \\
\hline Nonane & 1 & trans-Decalin & 3 & 2-Pentanone & 4 \\
\hline 2,6-Dimethyl- & 3 & 2-Methyl- & 11 & 2-Hexanone & 2 \\
\hline Decane & 3 & Cyclotetradecane & 4 & 3-Hexanone & 11 \\
\hline 2,4,6-Trimethyl- & 4 & \multirow{3}{*}{ Alkenes } & \multirow{3}{*}{$\begin{array}{l}\text { Conc. } \\
\left(\mathrm{mg} / \mathrm{m}^{3}\right) \\
\end{array}$} & Two other C6 alkanones & 3 \\
\hline Undecane & 27 & & & 2-Heptanone & 2.5 \\
\hline 2-Methyl- & 18 & & & 6-Methyl- & 5 \\
\hline 3-Methyl- & 13 & Propene & & 3-Heptanone & 3 \\
\hline 4-Methyl- & 5 & 2-Methyl- & 3 & 2-Octanone & \\
\hline 5-Methyl- & 4 & 1-Butene & 11 & Two other C8 alkanones & 5 \\
\hline 2,4-Dimethyl- & 4 & 1-Pentene & 4 & 2-Nonanone & 7 \\
\hline 2,6-Dimethyl- & 27 & 1-Hexene & 5 & One other $\mathrm{C} 9$ alkanones & 2 \\
\hline 2,10- Dimethyl- & 24 & 1-Undecene & & 3-Dodecanone & 6 \\
\hline 3,7-Dimethyl- & 12 & 1-Dodecene & & 3-Tridecanone & 4 \\
\hline Dodecane & 260 & Two other C12 alkenes & 2 & One other $\mathrm{C} 13$ alkanone & 6 \\
\hline 4-Methyl- & 11 & 1-Tridecene & & & \\
\hline 4,6-Dimethyl- & 35 & One other $\mathrm{C} 13$ alkene & 5 & \multirow{2}{*}{ Nitriles } & \multirow{2}{*}{$\begin{array}{l}\text { Conc, } \\
\left(\mathrm{mg} / \mathrm{m}^{3}\right)\end{array}$} \\
\hline 2,6,10-Trimethyl- & 24 & 1- Tetradecene & & & \\
\hline 2,6,11-Trimethyl- & 4 & Two other C14 alkenes & 4 & Acetonitrile & 14 \\
\hline Five other $\mathrm{C} 12$ alkanes & 25 & 1-Pentadecene & & Propanenitrile & 7 \\
\hline Tridecane & 370 & One other $\mathrm{C} 15$ alkene & 9 & Butanenitrile & 6 \\
\hline 2-Methyl- & 14 & \multirow{3}{*}{ Alcohols and Ethers } & \multirow{3}{*}{$\begin{array}{l}\text { Conc, } \\
\left(\mathrm{mg} / \mathrm{m}^{3}\right)\end{array}$} & Pentanenitrile & 3 \\
\hline 3-Methyl- & 2 & & & Hexanenitrile & 3 \\
\hline 5-Methyl- & 4 & & & Heptanenitrile & 3 \\
\hline 6-Methyl- & 19 & 1-Butanol & 80 & Octanenitrile & 2 \\
\hline One other $\mathrm{C} 13$ alkanes & 11 & Cyclopentanol & 2 & \multirow{3}{*}{$\begin{array}{c}\text { Miscellaneous } \\
\text { Compounds }\end{array}$} & \\
\hline Tetradecane & 75 & 2-Phenyl-2-propanol & 9 & & \multirow{2}{*}{$\begin{array}{c}\text { Conc, } \\
\left(\mathrm{mg} / \mathrm{m}^{3}\right)\end{array}$} \\
\hline Six other C14 alkanes & 30 & 2,3 Dihydrofuran & 2 & & \\
\hline Pentadecane & 8 & Tetrahydrofuran & 10 & Dichloromethane & 5 \\
\hline Three other $\mathrm{C} 15$ alkanes & 14 & & & 1,1-Dichloroethene & 3 \\
\hline Hexadecane & 25 & & & \begin{tabular}{|l|} 
Ethyl acetate \\
\end{tabular} & 30 \\
\hline One other $\mathrm{C} 16$ alkane & 7 & & & Butyl acetate & 6 \\
\hline Heptadecane & 3 & & & One carboxylate ester & 2 \\
\hline & & & & One phthalate ester & 2 \\
\hline & & & & One alkyl nitrite ester & 3 \\
\hline & & & & One phenol & 4 \\
\hline & & & & Hexamethylcyclotrisiloxane & 2 \\
\hline
\end{tabular}

Note: Information in this table is from Jenkins, R. A., A. B. Dindal, C. E. Huggins, C. Y. Ma, J. T. Skeen, and R. R. Smith, 1994, Analysis of Tank 24I-C-I03 Headspace Components from Sampling Job 7b, Oak Ridge National Laboratory, Oak Ridge, Tennessee. 


\section{RPP-6664 REV 0}

Table 2-9. Volatile Organic Compounds at Concentrations Greater than One Milligram per Cubic Meter in the Ventilation Stack of Tank 241-C-106 During Sluicing on March 7, 1999. (2 sheets)

\begin{tabular}{|c|c|}
\hline Alkanes & $\begin{array}{l}\text { Conc } \\
\left(\mathbf{m g} / \mathbf{m}^{3}\right)\end{array}$ \\
\hline Propane & 7 \\
\hline Butane & 17 \\
\hline 2-Methyl- & 2 \\
\hline Pentane & 9 \\
\hline 2-Methyl- & 3 \\
\hline Hexane & 13 \\
\hline 2-Methyl- & 4 \\
\hline Heptane & 80 \\
\hline 3-Methyl- & 86 \\
\hline 2,3-Dimethyl- & 2 \\
\hline 3-Ethyl- & 9 \\
\hline Octane & 20 \\
\hline Nonane & 19 \\
\hline Deane & 28 \\
\hline 4-Methyl- & 8 \\
\hline 3,7-Dimethyl- & 3 \\
\hline 2,6,7-Trimethyl- & 2 \\
\hline Undecane & 44 \\
\hline 2-Methyl- & 3 \\
\hline 6-Methylundecane & 2 \\
\hline 2,6-Dimethyl- & 4 \\
\hline Dodecane & 64 \\
\hline 6-Methyl- & 6 \\
\hline 2,6,10-Trimethyl- & 7 \\
\hline Tridecane & 45 \\
\hline 7-Methyl- & 3 \\
\hline Tetradecane & 5 \\
\hline 6-Methyl- & 19 \\
\hline One other C13 alkanes & 11 \\
\hline Tetradecane & 75 \\
\hline Six other C14 alkanes & 30 \\
\hline Pentadecane & 8 \\
\hline Three other C15 alkanes & 14 \\
\hline Hexadecane & 25 \\
\hline One other C16 alkane & 7 \\
\hline Heptadecane & 3 \\
\hline
\end{tabular}

\begin{tabular}{|l|c|}
\hline Cycloalkanes & Conc \\
\hline Cyclopropane & (mg/m \\
\hline Ethyl- & \\
\hline Butyl- & 2 \\
\hline trans-1-Butyl-2-methyl- & 10 \\
\hline Cyclobutane & \\
\hline Butyl- & 23 \\
\hline Cyclopentane & \\
\hline Ethyl- & 2 \\
\hline Cyclohexane & \\
\hline Methyl- & 2 \\
\hline Ethyl- & 2 \\
\hline Pentyl- & 2 \\
\hline 1-Methyl-3-propyl- & 2 \\
\hline (2-Methylpropyl)- & 3 \\
\hline 2-Butyl-1,1,3-trimethyl & 2 \\
\hline 1,1,3-Trimethyl- & 3 \\
\hline Trans-Decalin & 12 \\
\hline 2-Methyl- & 6 \\
\hline 2,3-Dimethyl- & 16 \\
\hline 2,6-Dimethyl- & 4 \\
\hline
\end{tabular}

\begin{tabular}{|c|c|}
\hline $\begin{array}{l}\text { Alkenes and } \\
\text { Cycloalkenes }\end{array}$ & $\begin{array}{c}\text { Conc. } \\
\left(\mathrm{mg} / \mathrm{m}^{3}\right)\end{array}$ \\
\hline Propene & 8 \\
\hline 2-Methyl- & 5 \\
\hline 1-Butene & 35 \\
\hline E-2-Butene & 2 \\
\hline Z-2-Butene & 2 \\
\hline 1-Pentene & 12 \\
\hline 4-Methyl- & 2 \\
\hline E-2-Pentene & 3 \\
\hline Z-2-Pentene & 2 \\
\hline 1-Hexene & 34 \\
\hline 2-Methyl- & 2 \\
\hline E-2-Hexene & 2 \\
\hline 5-Methyl- & 2 \\
\hline Z-2-Hexene & 3 \\
\hline 5-Methyl- & 2 \\
\hline \multicolumn{2}{|l|}{ E-3-Hexene } \\
\hline 2-Methyl- & 2 \\
\hline Z-3-Hexene & 3 \\
\hline 1-Heptene & 29 \\
\hline 3-Methyl- & 4 \\
\hline E-2-Heptene & 160 \\
\hline Z-2-Heptene & 110 \\
\hline 3-Methyl- & 25 \\
\hline E-3-Heptene & 6 \\
\hline Z-3-Heptene ${ }^{a}$ & 80 \\
\hline 5-Methyl- & 13 \\
\hline 3-Methyleneheptane & 95 \\
\hline E-2-Octene & 12 \\
\hline Z-2-Octene & 5 \\
\hline 4-Octene isomer & 6 \\
\hline Octene isomer & 15 \\
\hline 1-Decene & 7 \\
\hline 1 or Z-3-Undecene & 6 \\
\hline 3-Tridecanone & 4 \\
\hline One other $\mathrm{C} 13$ alkanone & 6 \\
\hline Cyclopentene & 3 \\
\hline Dimethyl & 5 \\
\hline
\end{tabular}


Table 2-9. Volatile Organic Compounds at Concentrations Greater than One Milligram per Cubic Meter in the Ventilation Stack of Tank 241-C-106 During Sluicing on March 7, 1999. (2 sheets)

\begin{tabular}{|l|c|}
\hline $\begin{array}{c}\text { Alkadienes } \\
\text { and Ethynes }\end{array}$ & $\begin{array}{c}\text { Conc } \\
\left(\mathbf{m} \mathbf{g} / \mathbf{m}^{3}\right)\end{array}$ \\
\hline 2,3-Hexadiene & \\
\hline 2-Methyl- & 47 \\
\hline Heptadiene Isomer & 2 \\
\hline 1,6-Octadiene & 4 \\
\hline 1-Hexyne & 2 \\
\hline 2-Hexyne & 2 \\
\hline 2-Heptyne & 22 \\
\hline
\end{tabular}

\begin{tabular}{|c|c|}
\hline $\begin{array}{c}\text { Aromatic } \\
\text { Hydrocarbons }\end{array}$ & $\begin{array}{c}\text { Conc. } \\
\left(\mathbf{m g} / \mathbf{m}^{3}\right)\end{array}$ \\
\hline Benzene & \\
\hline Methyl- & 2 \\
\hline
\end{tabular}

\begin{tabular}{|l|c|}
\hline $\begin{array}{c}\text { Aldehydes } \\
\text { and Ketones }\end{array}$ & $\begin{array}{c}\text { Conc. } \\
\left(\mathbf{m g} / \mathbf{m}^{3}\right)\end{array}$ \\
\hline Butanal & 2 \\
\hline Acetone & 3 \\
\hline 2-Pentanone & 6 \\
\hline 2-Hexanone & 4 \\
\hline 3-Hexanone & \\
\hline 5-Methyl & 2 \\
\hline 2-Heptanone & 22 \\
\hline 3-Heptanone & 170 \\
\hline 4-Heptanone & 50 \\
\hline 3-Methyl- & 3 \\
\hline 2-Octanone & 4 \\
\hline 3-Octanone & 3 \\
\hline 4-Octanone & 10 \\
\hline
\end{tabular}

\begin{tabular}{|l|c|}
\hline \multirow{2}{*}{$\begin{array}{c}\text { Nitriles } \\
\text { Butanenitrile }\end{array}$} & $\begin{array}{c}\text { Conc. } \\
\left(\mathbf{m g} / \mathbf{m}^{3}\right)\end{array}$ \\
\hline 2-Methylene & 2 \\
\hline Hexanenitrile & 2 \\
\hline Heptanenitrile & 5 \\
\hline 3-Methyl- & 9 \\
\hline Octanenitrile & 13 \\
\hline Nonanenitrile & 13 \\
\hline Decanenitrile & 6 \\
\hline
\end{tabular}

\begin{tabular}{|l|c|}
\hline $\begin{array}{c}\text { Alcohols } \\
\text { and Ethers }\end{array}$ & $\begin{array}{c}\text { Conc } \\
\left(\mathbf{m g} / \mathbf{m}^{3}\right)\end{array}$ \\
\hline 1-Butanol & 3 \\
\hline 3-Heptanol & 14 \\
\hline 2-Ethylhexanol & 110 \\
\hline Dibutyl ether & 12 \\
\hline 1,2-Diethyl-1,4-epoxybutane & 35 \\
\hline 1,3-Diethyl-1,4-epoxybutane & 30 \\
\hline
\end{tabular}

Note: The concentrations shown are of the target analytes, compounds whose identifies have been confirmed, and compounds that have been tentatively identified compounds in a sample (VSO06-237-5071) collected during sluicing operations. The data in this table is from:

- Stauffer, L. A., and L. M. Stock, 1999, Origins of Volatile Organic Compounds Emerging from Tank 241-C-I06 during Sluicing, HNF-4261, Rev. 1, Lockheed Martin Hanford Corp. for Fluor Daniel Hanford, Inc., Richland, Washington.

- Bonfoey, D. B., M. J. Duchsherer, G. A. Fies, L. D. Lockard, K.O. Pennock, L. A. Pingel, J. Y. Smith, M. Stauffer, R. S. Viswanath, M. L. Myers, and L. L. Lockrem, 1999, Tank Vapor Sampling and Data Analysis Package for Tank 241-C-106 Waste Retrieval Sluicing System Process Text, Sampled December 16, 1998, HNF-3949, Rev. 0, Numatec Hanford Corp., Richland, Washington.

${ }^{a}$ These heptenes coelute, and the reported concentration is $50 \%$ of the total observed concentration.

The extensive nature of the oxidation reactions of the NPH is shown in Table 2-8 by the simultaneous appearance of low molecular weight oxidation products such as propene, the butenes, acetone, and butanal together with homologous families of ketones and nitriles ranging from propanone to tridecanone and propanenitrile to octanenitrile in the dome space of tank 241-C-103 (Jenkins et al. 1995). These substances emerge from the waste together with the original constituents and other unfragmented compounds including dodecene, tridecene, and 
tetradecene formed in the initial steps of the oxidation reactions of the hydrocarbons (Jenkins et al. 1995).

The same families of compounds evolved from tank 241-C-106 during sluicing operations as shown in Table 2-9. However, heptanes, heptenes, and heptanones are especially abundant in the mixture of volatile organic compounds from this tank (Bonfoey et al. 1999). These substances are produced by the radiolytic oxidation of sodium bis(2-ethylhexyl) phosphate (Stauffer and Stock 1999).

More generally, 3-octanone, a chemical marker indicative of the oxidation of the NPHs, has been detected in the dome spaces of 50 single-shell tanks and 3-heptanone, a chemical marker also indicative of the oxidation of the NPHs and sodium bis(2-ethylhexyl)phosphate has been detected in the dome spaces of 45 single-shell tanks according to information in the Tank Waste Information Network System.

The composition of the volatile organic compounds retained within the waste in tank 241-SY-101 has been established by the analysis of a gas-rich waste sample withdrawn from a location beneath the crust (Mahoney et al. 1999; Evans et al. 1999). The results are shown in Table 2-10.

The observations presented in Table 2-10 and other information obtained in the Retained Gas Sampling Program (Mahoney et al. 1999) enable the calculation of the concentrations of the organic gases and organic solutes within the waste. The 20 most abundant compounds account for more than $90 \%$ of the organic material. Eight of the 20 substances, including propane, propene, cyclopropane, butane, the butenes, cyclobutane, and butadiene, are essentially insoluble in the liquid waste and have boiling points that are less than the temperature of the waste. These substances have very low concentrations in the liquid and are retained in gaseous form. Ten of the 20 substances, including methanol, ethanol, 1-propanol, 2-propanol, 1-butanol, acetone, 2-butanone, methyl amine, dimethyl amine, and ethyl amine, are soluble in the liquid waste. These substances, like ammonia, are stored principally in the liquid phase of the waste.

The concentrations of the principal gaseous organic compounds with two, three, and four carbon atoms were estimated on the basis of the information assembled in Table 2-10 and other observations from the Retained Gas Sampling Program (Mahoney et al. 1999). The results, which range from $0.02 \mu \mathrm{g} / \mathrm{L}$ to $1 \mu \mathrm{g} / \mathrm{L}$ liquid waste, are shown in Table 2-11 (Huckaby et al. 2000). 
Table 2-10. Organic Compounds at Concentrations Greater than One Milligram per Cubic Meter in a Retained Gas Sample from Tank 241-SY-101.

\begin{tabular}{|l|c|}
\hline \multicolumn{1}{|c|}{ Alkanes } & $\begin{array}{c}\text { Conc } \\
\text { (mg/m }\end{array}$ \\
\hline Methane
\end{tabular}

\begin{tabular}{|c|c|}
\hline Cycloalkanes & Conc. \\
\hline Cyclopropane & 75 \\
\hline cis-1,2-Dimethyl- & 2 \\
\hline
\end{tabular}

\begin{tabular}{|l|c|}
\hline \multicolumn{1}{|c|}{ Alkenes } & Conc, \\
\hline Propene & (mg/m $\left.{ }^{3}\right)$ \\
\hline 1-Butene & 245 \\
\hline 2-Butene (E) & 75 \\
\hline 2-Methyl-1-propene & 73 \\
\hline 1-Pentene & 4 \\
\hline 2-Methyl-1-butene & 10 \\
\hline 2-Methyl-2-butene & 4 \\
\hline 1-Hexene & 2 \\
\hline
\end{tabular}

\begin{tabular}{|l|c|}
\hline $\begin{array}{c}\text { Alkadienes } \\
\text { and Alkynes }\end{array}$ & $\begin{array}{c}\text { Conc, } \\
\left(\mathbf{m g} / \mathbf{m}^{3}\right)\end{array}$ \\
\hline 1,3-Butadiene & 170 \\
\hline Propyne & 11 \\
\hline
\end{tabular}

\begin{tabular}{|c|c|}
\hline $\begin{array}{c}\text { Aromatic } \\
\text { Compounds }\end{array}$ & $\begin{array}{c}\text { Conc. } \\
\text { (mg/m } \mathbf{3}^{3}\end{array}$ \\
\hline Benzene & 4 \\
\hline
\end{tabular}

\begin{tabular}{|c|c|}
\hline Alcohols & Conc. \\
\hline and Ethers & $\left(\mathbf{m g} / \mathbf{m}^{3}\right)$ \\
\hline
\end{tabular}

\begin{tabular}{|l|c|}
\hline Methanol & 300 \\
\hline Ethanol & 450 \\
\hline 2-Butoxy & 6 \\
\hline
\end{tabular}

\begin{tabular}{|l|c|}
\hline 2-Butoxy & 6 \\
\hline 1-Propanol & 94 \\
\hline 2,2-Dimethyl- & 5 \\
\hline
\end{tabular}

\begin{tabular}{|l|c|}
\hline 2-Propanol & 23 \\
\hline 2-Methyl- & 20 \\
\hline 1-Butanol & 195 \\
\hline 2-Butanol & 3 \\
\hline 3-Heptanol & 5 \\
\hline Tetrahydrofuran & 19 \\
\hline 1,4-Dioxane & 10 \\
\hline
\end{tabular}

\begin{tabular}{|l|c|}
\hline \multirow{2}{*}{ Ketones } & $\begin{array}{c}\text { Conc; } \\
\left.\mathbf{( n g}^{3} \mathbf{~ m}\right)\end{array}$ \\
\hline Propanone & 13 \\
\hline 2-Butanone & 7 \\
\hline Pentanone & \\
\hline 4-Methyl- & 2 \\
\hline
\end{tabular}

\begin{tabular}{|l|c|}
\hline \multirow{2}{*}{ Amines } & Conc, \\
\hline Methyl amine & $\left(\mathbf{m g} / \mathbf{m}^{3}\right)$ \\
\hline Dimethyl amine & 235 \\
\hline Ethyl amine & 5 \\
\hline 1-Methylaziridine & 50 \\
\hline Pyridine & 17 \\
\hline Pyrazine & 46 \\
\hline
\end{tabular}

\begin{tabular}{|l|c|}
\hline $\begin{array}{l}\text { Nitro and Nitroso } \\
\text { Compounds }\end{array}$ & $\begin{array}{c}\text { Conc, } \\
\left(\mathbf{m g} / \mathbf{m}^{3}\right)\end{array}$ \\
\hline Nitromethane & 4 \\
\hline 2-Methyl-2-nitropropane & 4 \\
\hline N-Nitrosodimethyl amine & 5 \\
\hline
\end{tabular}

Notes: Information in this table is from Evans, J. C., A. V. Mitroshkov, and L. A. Mahoney, 1999, SY-101 Retained Gas Vapor GC/MS Analysis, TW399.31, Pacific Northwest National Laboratory, Richland, Washington.

The sample was collected from the "bubbly slurry" below the crust in the convective layer. The sample contained approximately $45 \%$ gas by volume. The results of three analyses were averaged to obtain the information summarized in this table. Several silanes also were observed at concentrations greater than $1 \mathrm{mg} / \mathrm{m}^{3}$. 


\section{RPP-6664 REV 0}

Table 2-11. Concentrations of Organic Gases in the Gas-rich Slurry in Tank 241-SY-101 Before Waste Transfers in 2000.

\begin{tabular}{|l|c|c|}
\hline \multirow{2}{*}{ Compound } & $\begin{array}{c}\text { Concentration in Retained Gas' } \\
\text { Parts Per Million Volume (ppm) }\end{array}$ & $\begin{array}{c}\text { Concentration in Gas-rich Slurry } \\
\text { (pg/) }\end{array}$ \\
\hline Methane & 720,000 & 2880 \\
\hline Propane & 152 & 0.6 \\
\hline Propene & 249 & 1.0 \\
\hline Cyclopropane & 49 & 0.2 \\
\hline Butane & 103 & 0.5 \\
\hline 1-Butene & 48 & 0.2 \\
\hline e-2-Butene & 151 & 0.8 \\
\hline Cyclobutane & 4 & 0.02 \\
\hline 1,3-Butadiene & 109 & 0.5 \\
\hline
\end{tabular}

- ${ }^{\mathrm{a}}$ The concentration in the retained gas is from Evans, J. C., A. V. Mitroshkov, and L. A. Mahoney, 1999, SY-101 Retained Gas Vapor GC/MS Analysis, TW399.31, Pacific Northwest National Laboratory, Richland, Washington.

The concentrations of the principal soluble organic compounds were estimated on the basis of the results assembled in Table 2-10 and Henry's law. Cowley et al. (2000) have pointed out that large uncertainties are associated with the calculated concentrations of the organic molecules because the Henry's law constants have not been determined by the compounds in concentrated solutions of salts. Nevertheless, the observations show that the liquid wastes contain small amounts of low molecular weight organic compounds. The results are shown in Table 2-12.

Table 2-12. Concentrations of Soluble Organic Compounds in Gas-Rich Slurry in Tank 241-SY-101 Before Waste Transfers in 2000. (2 sheets)

\begin{tabular}{|l|c|c|c|}
\hline \multirow{2}{*}{\begin{tabular}{c|c|c|} 
Compound \\
Methanol
\end{tabular}} & $\begin{array}{c}\text { Concentration in } \\
\text { Retained Gas } \\
\text { (ppmy) }\end{array}$ & $\begin{array}{c}\text { Calculated } \\
\text { Concentration in Water } \\
\text { (g/kg) }\end{array}$ & $\begin{array}{c}\text { Estimated Concentration } \\
\text { in Gas-rich Slurry }^{\mathbf{c}^{*}}\end{array}$ \\
\hline Ethanol & 259 & 0.69 & 0.09 \\
\hline 1-Propanol & 265 & 0.66 & 0.08 \\
\hline 2-Propanol & 44 & 0.08 & 0.01 \\
\hline 1-Butanol & 10 & 0.02 & 0.00 \\
\hline Methyl amine & 73 & 0.18 & 0.02 \\
\hline Dimethyl amine & 206 & 0.15 & 0.02 \\
\hline Ethyl amine & 208 & 0.14 & 0.02 \\
\hline Pyridine & 31 & 0.03 & 0.00 \\
\hline Acetone & 44 & 0.13 & 0.02 \\
\hline
\end{tabular}




\section{RPP-6664 REV 0}

Table 2-12. Concentrations of Soluble Organic Compounds in Gas-Rich Slurry in Tank 241-SY-101 Before Waste Transfers in 2000. (2 sheets)

\begin{tabular}{|c|c|c|c|}
\hline Compound & $\begin{array}{c}\text { Concentration in } \\
\text { Retained Gas } \\
\text { (ppmv) }\end{array}$ & $\begin{array}{l}\text { Calculated } \\
\text { Concentration in Water' } \\
\text { (g/kg) }\end{array}$ & $\begin{array}{l}\text { Estimated Concentration } \\
\text { in Gas-rich Slurry' } \\
\text { (g/kg) }\end{array}$ \\
\hline 2-Butanone & 3 & 0.002 & 0.0003 \\
\hline
\end{tabular}

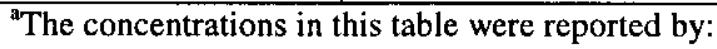

- Evans, J. C., A. V. Mitroshkov, and L. A. Mahoney, 1999, SY-101 Retained Gas Vapor GC/MS Analysis, TW399.31, Pacific Northwest National Laboratory, Richland, Washington.

- Mahoney, L. A., Z. I. Antoniak, J. M. Bates, and M. E. Dahl, 1999, Retained Gas Sampling Results for the Flammable Gas Program, PNNL-13000, Pacific Northwest National Laboratory, Richland, Washington. (2000).

${ }^{\mathrm{b}}$ The concentration in pure water is based upon the known Henry's law constants as reported in Cowley et al.

${ }^{c}$ The concentration in waste is based upon estimated Henry's law constants for waste as reported in Cowley et al. (2000).

The mixture of organic compounds in tank 241-SY-101 differs somewhat from the mixtures in tanks 241-C-103 and 241-C-106. Methyl amine, ethyl amine, dimethyl amine, and pyrazine, which have not been reported to be constituents of the two $\mathrm{C}$ farm tanks, are structurally related to EDTA and HEDTA and presumably originate from these nitrogen-containing complexants rather than from the solvents. However, the mixture also contains the original NPHs together with alkanes, alkenes, and cycloalkanes containing three or more carbon atoms that were formed through fragmentation reactions of the original hydrocarbon and the phosphate esters rather than from the complexants. Similarly, the alcohols and ketones with three or more carbon atoms also originate from solvent molecules. The abundant low molecular weight alcohols could originate either from the complexants or from the solvents. Whatever the exact origins of the low molecular weight compounds, the observations provide evidence for the oxidative decomposition of the organic solvents and complexants and for the accumulation of these remnants in the liquid waste.

The continuous evolution of the organic solvents and their oxidation products from the waste negates a quantitative assessment of the extent of the oxidation reactions. However, the information in the tank characterization reports and in the Tank Waste Information Network System database provide convincing evidence for the widespread occurrence of oxidation reactions that simultaneously produce hydrogen, ammonia, nitrous oxide, and nitrogen.

\subsection{GAS FORMATION AND ORGANIC OXIDATION: CHEMICALLY COUPLED PROCESSES}

The oxidation reactions of the organic compounds could, in principle, be interpreted as a consequence of a simple chemical process in which an organic substance such as glycolate ion is oxidized to form oxalate ion, and nitrate ion is reduced to nitrite ion:

$\mathrm{HOCH}_{2} \mathrm{CO}_{2} \mathrm{Na}+2 \mathrm{NaNO}_{3}+\mathrm{NaOH} \rightarrow \mathrm{NaO}_{2} \mathrm{CCO}_{2} \mathrm{Na}+2 \mathrm{NaNO}_{2}+2 \mathrm{H}_{2} \mathrm{O}$ 
However, the chemical processes occurring in the waste are more complex because the inorganic oxidants become enmeshed in reaction cascades leading to the formation of gases. Indeed, it has been recognized since 1980 that the generation of gases in the waste was closely coupled with the presence of organic compounds. Early reports of slurry growth attributed the readily measurable changes in the volume of freshly evaporated wastes to gas formation and related the growth phenomena to the presence of high concentrations of complexants in the waste, as outlined in the work concerning the transfer of evaporator waste to tank 241-A-101 (Jansky 1980a, 1980b, 1980c, 1980d, 1980e, 1981, 1984; Teats 1982a, 1982b). More recently, Agnew pointed out the close correspondence between the tanks predicted to have high organic contents and the tanks included in the original flammable gas watch list (Agnew 1995, 1996, Agnew et al. 1997). The findings are reinforced by the broad occurrence of gas formation summarized in Section 2.1 and the equally broad occurrence of organic oxidation reactions summarized in Section 2.2. The inferences drawn from the field observations have been reinforced by the targeted investigations of pure substances, simulants, and wastes discussed in the next sections. 
RPP-6664 REV 0

\subsection{THE OXIDATION OF ORGANIC COMPLEXANTS AND SOLVENTS}

\subsection{INTRODUCTION}

Fundamental and targeted investigations of the rates and products of organic oxidation reactions and gas formation have been carried out at the Hanford Site, Argonne National Laboratory, Georgia Institute of Technology, and Pacific Northwest National Laboratory. The results of these investigations, when combined with the results of other investigations of the key pathways in radiation chemistry and information from the chemical literature about conventional free radical and ionic organic reactions, provide a technical basis to describe the behavior of tank waste and to construct qualitative and quantitative chemical models having predictive capabilities.

Overall, the organic complexants and solvents are oxidized through long sequences of chemical reactions to form volatile compounds, which emerge from the waste, or sodium carboxylates and sodium carbonate, which are retained in the waste, as the inorganic oxidants are reduced to form nitrogen-containing gases and hydrogen.

The radiolysis of water and the subsequent reactions of the radicals produced from water with nitrate and nitrates ions provide the reagents necessary for oxidation of the organic compounds in the waste. The radicals produced in these reactions abstract a hydrogen atom or an electron from the organic constituents to initiate chemical transformations. The initial radiolytic processes have negligible activation energies, but the rates of the ensuing chemical reactions are temperature dependent. Other radical reactions are initiated by the radicals formed by the thermal decomposition of inorganic constituents, particularly nitrite ion. These reactions, of course, have high activation energies.

Meisel et al. (1991a, 1991b, 1993, 2000) observed that gas generation continued after the radiolysis of the waste had been stopped and concluded that chemical reactions continued as the unstable organic and inorganic intermediates formed in the radiolytic reaction decomposed. Work in other laboratories has confirmed this concept and demonstrated that the radiolytic processes are synergistically coupled with other chemical reactions to fragment and oxidize the original complexants and solvents. It is now recognized that both ionic and free radical reactions contribute to the oxidation of the complexants. Ionic processes, which occur in the absence of radiation, include the base-catalyzed fragmentation reaction of citrate ion (Ashby et al. 1994; Barefield et al. 1995, 1996; Camaioni et al. 1998), the aluminate ion-catalyzed oxidation of complexants with hydroxyl groups (Delegard 1980, 1987; Ashby et al. 1994; Barefield et al. 1995, 1996; Camaioni et al. 1998; Camaioni and Autrey 2000), and the base-catalyzed oxidation of aldehydes that is responsible for most of the hydrogen generated in the waste (Ashby et al. 1993, 1994; Barefield et al. 1995, 1996; Karpoor et al. 1995). Reactions between the original organic complexants and water are not significant, but TBP reacts slowly with water in alkaline solution to form butanol and sodium dibutyl phosphate (DBP) (Burger 1955; Camaioni et al. 1996a). Other hydrolysis reactions transform the intermediate nitrite and nitrate esters, nitroso and nitro compounds, acetals and ketals and their related nitrogen derivatives, oximes and hydroxamates, amides, and nitriles into alcohols, aldehydes and ketones, and sodium 
carboxylates (Ashby et al. 1993, 1994; Barefield et al. 1995, 1996; Camaioni et al. 1997, 1998; Camaioni and Autrey 2000).

The principal reaction pathways shown in Figure 3-1 guide the discussion in the next section. The three routes for the formation of reactive inorganic radicals and ions are shown at the top of the figure. The reactions of these substances with organic compounds form free radicals or reactive intermediates as illustrated in the center of the figure. The ensuing radical recombination and ionic reactions produce families of organic intermediates and the array of ionic reactions that convert these intermediates into end products or into remnant molecules that repeat the cycle as sketched at the bottom of the figure.

Figure 3-1. Principal Reaction Pathways for the Oxidation of Organic Compounds.

$$
\begin{gathered}
\text { Inorganic Constituents } \\
\mathrm{H}_{2} \mathrm{O}, \mathrm{NaNO}_{2}, \mathrm{NaNO}_{3}, \mathrm{NaAl}(\mathrm{OH})_{4}, \mathrm{NaOH}
\end{gathered}
$$

Radiolytic and Thermal Processes

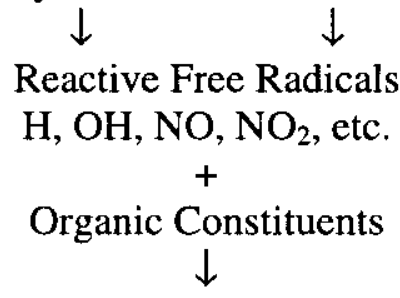

Organic Free Radicals

Beta Scission

and

Recombination Reactions

$\downarrow$

Organic Intermediates

$\downarrow$

Remnant Molecules

Formate, Oxalate, Carbonate Ions
Thermal Processes<smiles>[AlH2]</smiles>
Ionic Reagents $\mathrm{OH}^{-}, \mathrm{Al}(\mathrm{OH})_{4}{ }^{-}, \mathrm{NO}_{2}{ }^{-}$, etc. $+$

Organic Constituents $\downarrow$

Organic Intermediates

Hydrolysis Reactions

and

Base Catalyzed Oxidation<smiles>[AlH2]</smiles>

Other Organic Intermediates<smiles>[AlH]</smiles>

Remnant Molecules

Formate, Oxalate, Carbonate Ions

Organic Intermediates and Remnant Molecules Participate

in Free Radical and Thermal Reactions

and Remnant Molecules Repeat the Reaction Cycle

The rate of decomposition of each organic molecule is the sum of rates of the reactions occurring along the different reaction channels. The rates of the individual reactions depend on the composition of the waste under consideration (e.g., concentrations of reagents in the tank, temperature, radiation dose). The initial radiolytic reactions are temperature independent, but the ensuing radical and ionic reactions are temperature dependent. The thermally induced free radical reactions have appreciable activation energies and occur rather slowly at temperatures 
below $50^{\circ} \mathrm{C}$. The base-catalyzed hydrolysis reactions of amides and the reactions of hydroxide ion with aldehydes proceed quite rapidly under typical storage conditions. The aluminate ion-promoted hydrogen transfer reactions occur somewhat more slowly. Differences in the rates of reaction in the different phases are uncertain at present.

The relative rates and products of these reactions will be examined in Section 3.2 before the more complete examination of the chemical reaction pathways in Section 3.3.

\subsection{PRODUCT DISTRIBUTIONS AND RELATIVE RATES OF OXIDATION}

\subsubsection{Product Distributions and Relative Rates for Complexants}

3.2.1.1 Products. The identification of organic constituents in waste, which was discussed in Section 2.2 , has been complemented by targeted laboratory investigations of the products formed from pure substances during thermal and radiolytic reactions in simulants. The results of the thermal reactions of the four principal complexants - glycolate ion, citrate ion, HEDTA, and EDTA - are discussed first.

Delegard (1987) reported glycolate ion thermally decomposes in waste to yield hydrogen, nitrous oxide, nitrogen, ammonia, and oxalate ion. More recent work has demonstrated formate and carbonate ions are also produced from this substance (Camaioni et al. 1997, 1998).

Citrate ion decomposes thermally to give oxalate and acetate ions as the end products (Ashby et al. 1994). The thermal reaction is catalyzed by hydroxide ion.

The thermal decomposition reactions of HEDTA and EDTA provide the same principal products. Delegard (1987) reported HEDTA degraded thermally to produce the same gases obtained from glycolate ion and organic fragmentation products including ED3A and oxalate ion. Ashby et al. (1994) found thermal aging of HEDTA ion also produced s-EDDA, IDA, glycinate, and formate ions. Camaioni et al. $(1997,1998)$ have confirmed the results of the previous investigators.

Barefield et al. $(1995,1996)$ provided a detailed accounting of the thermal decomposition of trisodium HEDTA in simulated waste mixtures for reactions that were carried out for 7,000 hours. The course of the reaction is illustrated in Figure 3-2. The concentrations of the reaction products are normalized to 100 moles of HEDTA. ED3A is the most abundant remnant at this stage of the thermal reaction, and the yield of formate ion greatly exceeds the yield of oxalate ion.

Very similar product distributions are obtained from the complexants during the radiolysis of simulants. The results of a recent investigation of the reaction products by Camaioni et al. (1998) are summarized in Table 3-1. 


\section{RPP-6664 REV 0}

Figure 3-2. Consumption of Hydroxyethylethylenediaminetriacetate and Appearance of Principal Organic Products during the Thermal Reaction at $90^{\circ} \mathrm{C}$ in a Simulated Waste under Argon.

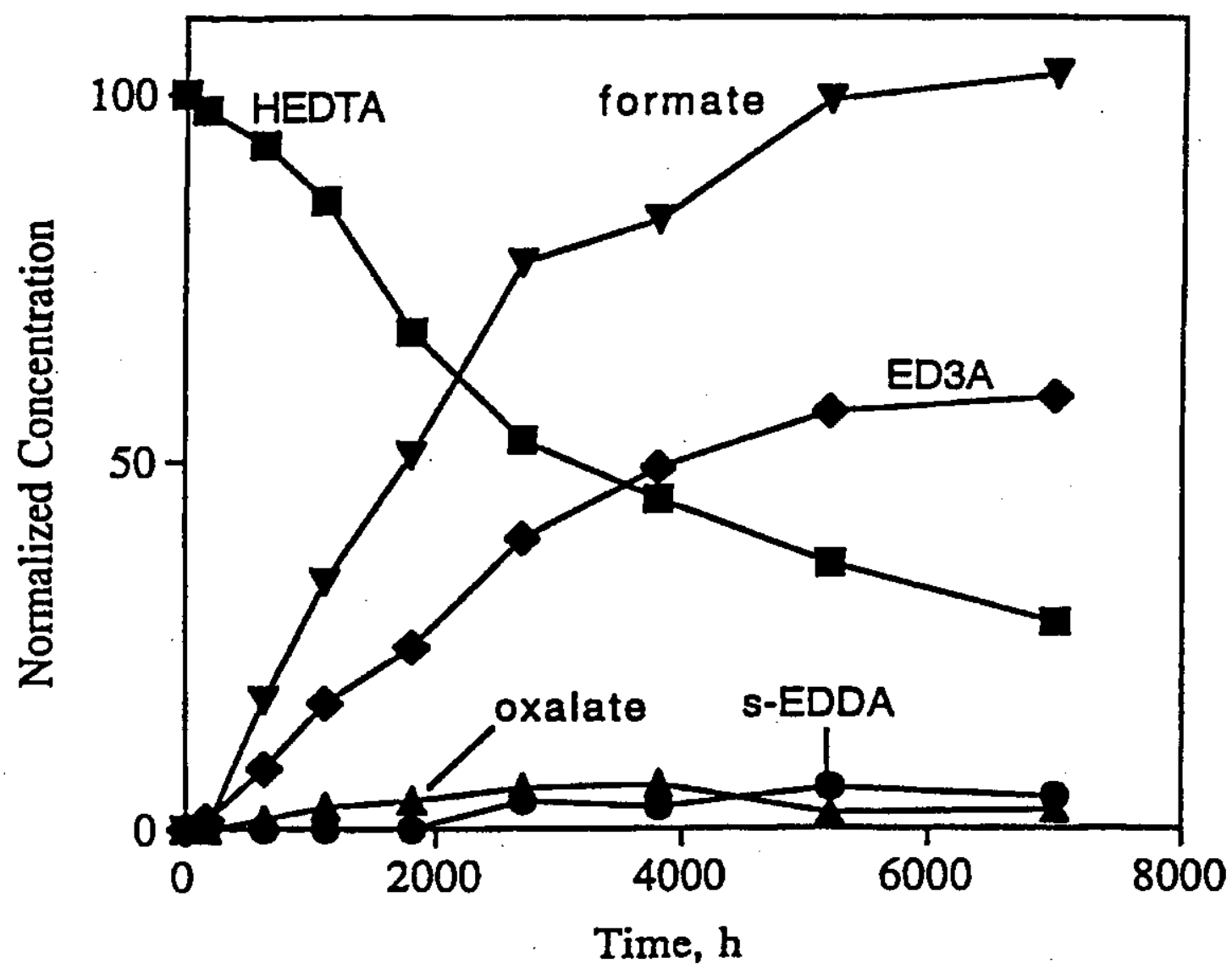

Table 3-1. Principal Products of the Radiolysis of Complexants in Simultants. (2 sheets)

\begin{tabular}{|c|c|c|c|c|}
\hline Compound & Relative Amount & Definitely Identified & Possibly Present & Absent \\
\hline \multirow{4}{*}{ EDTA } & Major & $\begin{array}{c}\text { ED3A, s-EDDA, IDA, } \\
\text { Formate }\end{array}$ & HEDTA \\
\cline { 2 - 5 } & Minor & $\begin{array}{c}\text { Acetate, Glycolate } \\
\text { Glycinate }\end{array}$ & $\begin{array}{c}\text { u-EDDA } \\
\text { NTA }\end{array}$ & \\
\hline \multirow{3}{*}{ HEDTA } & Major & $\begin{array}{c}\text { s-EDDA, IDA, } \\
\text { Formate }\end{array}$ & NTA & $\begin{array}{c}\text { EDTA, } \\
\text { ED3A }\end{array}$ \\
\cline { 2 - 5 } & Minor & Glycinate & u-EDDA & NTA \\
\hline \multirow{3}{*}{ u-EDDA } & Major & IDA, Formate & & \\
\cline { 2 - 5 } & Minor & Glycinate & & \\
\hline
\end{tabular}


Table 3-1. Principal Products of the Radiolysis of Complexants in Simultants. (2 sheets)

\begin{tabular}{|c|c|c|c|c|}
\hline Compound & Relative Amount & Definitely Identified & Possibly Present & Absent \\
\hline \multirow{3}{*}{ S-EDDA } & Major & IDA, Formate & EDMA & \\
\cline { 2 - 5 } & Minor & Glycinate & & \\
\hline \multirow{2}{*}{ NTA } & Major & IDA, Formate & & \\
\cline { 2 - 5 } & Minor & Glycinate & & \\
\hline IDA & Major & Glycinate, Formate & & Acetate, Glycolate \\
\hline Glycine & Major & Formate, Oxalate & & \\
\hline Glycolate & Major & Formate, Oxalate & & \\
\hline
\end{tabular}

Note: Information in this table is from D. M. Camaioni, W. D. Samuels, J. C. Lenihan, S. T. Sharma, A. K. Autrey, M. A. Lilga, M. O. Hogan, S. A. Clauss, K. L. Wahl, and J. A. Campbell, 1998, Organic Tanks Safety Program Waste Aging Studies Final Report, PNNL-11909, Pacific Northwest National Laboratory, Richland, Washington.

ED3A = ethylenediaminetriacetate ion. IDA = iminodiacetate ion.

EDMA = ethylenediaminemonoacetate ion. NTA $=$ nitrilotriacetate ion.

EDTA = ethylenediaminetetraacetate ion. $\quad$ s-EDDA $=$ symmetrical-ethylenediaminediacetate ion.

HEDTA $=$ hydroxyethylethylenediaminetriacetate ion. u-EDDA $=$ unsymmetrical-ethylenediaminediacetate ion.

The radiolytic and thermal reactions of the complexants and their remnants provide the same products, but in somewhat different amounts. Careful analytical work indicates many products are obtained in low yield. To illustrate, the radiolysis of HEDTA yields several compounds in which the hydroxyethyl fragment is preserved (Ashby et al. 1994; Camaioni et al. 1998):

$$
\begin{gathered}
\left.\left(\mathrm{O}_{2} \mathrm{CCH}_{2}\right) \mathrm{NHCH}_{2} \mathrm{CH}_{2} \mathrm{~N}\left(\mathrm{CH}_{2} \mathrm{CO}_{2}\right)^{-}\right) \mathrm{CH}_{2} \mathrm{CH}_{2} \mathrm{OH} \\
\left(\mathrm{OO}_{2} \mathrm{CCH}_{2}\right)_{2} \mathrm{NCH}_{2} \mathrm{CH}_{2} \mathrm{NHCH}_{2} \mathrm{CH}_{2} \mathrm{OH} \\
\left(\mathrm{O}_{2} \mathrm{CCH}_{2}\right) \mathrm{NHCH}_{2} \mathrm{CH}_{2} \mathrm{NHCH}_{2} \mathrm{CH}_{2} \mathrm{OH} \\
\mathrm{H}_{2} \mathrm{NCH}_{2} \mathrm{CH}_{2} \mathrm{NHCH}_{2} \mathrm{CH}_{2} \mathrm{OH} \\
\mathrm{N}\left(\mathrm{CH}_{2} \mathrm{CO}_{2}^{-}\right)_{2} \mathrm{CH}_{2} \mathrm{CH}_{2} \mathrm{OH} \\
\mathrm{NH}\left(\mathrm{CH}_{2} \mathrm{CO}_{2}^{-}\right) \mathrm{CH}_{2} \mathrm{CH}_{2} \mathrm{OH}
\end{gathered}
$$

Toste (1998) investigated the radiolysis and thermal decomposition of NTA. He did not establish the concentrations of IDA or the other simple carboxylate ions, but he did detect 


\section{RPP-6664 REV 0}

$\mathrm{N}$-(methylamino)iminodiacetate, and other related dimeric compounds related to this substance. ${ }^{1}$ Their chemical structures are as follows:

$$
\begin{gathered}
\mathrm{N}\left(\mathrm{CH}_{2} \mathrm{NH}_{2}\right)\left(\mathrm{CH}_{2} \mathrm{CO}_{2}^{-}\right)_{2} \\
\left(\mathrm{H}_{2} \mathrm{NCH}_{2}\right)\left(\mathrm{CH}_{3}\right) \mathrm{NCH}_{2} \mathrm{CH}_{2} \mathrm{~N}\left(\mathrm{CH}_{2} \mathrm{NH}_{2}\right)\left(\mathrm{CH}_{2} \mathrm{CO}_{2}{ }^{-}\right)
\end{gathered}
$$

The observations of Ashby et al. (1994), Camaioni et al. (1998), and Toste (1998) imply that the wastes contain a broad array of different compounds, some of which are present in significant amounts and others of which are present in very low concentrations. The results show that the degradation reactions of the complexants generally proceed sequentially by removing two carbon atom fragments. Some of the steps in the oxidative decomposition of EDTA are shown in Figure 3-3 to illustrate this concept. For clarity, the important byproducts of the reactions, oxalate, formate, and carbonate ion, are shown only in the final reaction in the figure. The products designated in bold face have been detected in tank waste or in simulants by several investigators (Campbell et al. 1994, 1995a, 1995b, 1996a, 1996b, 1997; Ashby et al. 1994; Barefield et al. 1995, 1996; Camaioni et al. 1996a, 1996b, 1997, 1998; Evans et al. 1999, Mahoney et al. 1999).

In conclusion, the results of the laboratory investigations of the complexants presented in this section mirror the results obtained in the characterization program discussed in Section 2.2

3.2.1.2 Relative Rates. The thermal reactions occur quite slowly and are difficult to investigate in the laboratory. Consequently, only a few rates and relative rates have been determined.

Barefield et al. $(1995,1996)$ observed that glycolate ion was thermally decomposed more rapidly than the other complexants in simulants at $90^{\circ} \mathrm{C}$ and $120^{\circ} \mathrm{C}$. They estimated the half life of this substance to be less than one year at $60^{\circ} \mathrm{C}$. Preliminary investigations by Camaioni et al. (1996a, 1996b, 1997) provided the order of reactivity:

$$
\text { Glycolate }>\text { HEDTA }>\text { Citrate }>>\text { EDDA }>\text { EDTA, Glycinate, IDA, and NTA }
$$

More recent study of the long-term thermal reactions of simulants confirmed the earlier observations by providing quantitative relative rates for the decomposition of the original four complexants (Camaioni et al. 1998; Camaioni and Autrey 2000):

$$
\text { Glycolate (1.6) > HEDTA (1.1) > Citrate (1.0) >> EDTA }
$$

The radiolytic reactions proceed much more rapidly and their relative rates can be readily determined by competition experiments. Magnetic resonance techniques were used in competition reactions with formate ion to determine the relative rates of disappearance of organic complexants and remnants during the radiolysis of 10 compounds. The experiments were conducted at $20^{\circ}$ to $25^{\circ} \mathrm{C}$ in simulants containing 2 moles per liter $(M)$ sodium hydroxide and either $3.75 \mathrm{M}$ sodium nitrate and $1.25 \mathrm{M}$ sodium nitrite or $2.00 \mathrm{M}$ sodium nitrate and $2.00 \mathrm{M}$ sodium nitrite (Camaioni et al. 1997, 1998). The averaged results are shown in Table 3-2.

\footnotetext{
1 The discussion in the article (Toste 1998) implies that $\mathrm{N}$-(methylamino)iminodiacetate was present in the NTA employed in the experiments. Consequently, its presence and the presence of dimeric substances in the reaction products may be an artifact. The conclusions presented in the text do not depend on this complication.
} 
Figure 3-3. Reaction Pathways for the Oxidation of Ethylenediaminetriacetate.

EDTA $\rightarrow$ N-MeIDA (N-methyl iminodiacetate)

EDTA $\rightarrow$ ED3A (ethylenediaminetriacetate)

EDTA $\rightarrow$ NTA (nitrilotriacetate) + IDA (iminodiacetate)

ED3A $\rightarrow$ u-ED2A (unsymmetric ethylenediaminediacetate)

ED3A $\rightarrow$ NTA + G (glycinate)

ED3A $\rightarrow \mathrm{N}-\mathrm{MeIDA}+\mathrm{N}-\mathrm{MeG}$ (N-methylglycine)

$\mathrm{ED} 3 \mathrm{~A} \rightarrow \mathrm{IDA}+\mathrm{N}$-EtG (N-ethylglycine)

ED3A $\rightarrow$ s-ED2A (symmetric ethylenediaminediacetate)

$\mathrm{ED} 3 \mathrm{~A} \rightarrow \mathrm{N}-\mathrm{Me}-\mathrm{u}-\mathrm{ED} 2 \mathrm{~A}$ (N-methyl unsymmetric ethylenediaminediacetate)

$\mathrm{u}-\mathrm{ED} 2 \mathrm{~A} \rightarrow \mathrm{IDA}+\mathbf{A}$ (acetate)

$\mathrm{u}-\mathrm{ED} 2 \mathrm{~A} \rightarrow \mathrm{N}-\mathrm{MeIDA}+$ methylamine

$\mathrm{u}-\mathrm{ED} 2 \mathrm{~A} \rightarrow$ IDA + ethylamine

$\mathrm{u}-\mathrm{ED} 2 \mathrm{~A} \rightarrow \mathrm{ED} 1 \mathrm{~A}$ (ethylenediaminemonoacetate)

$\mathrm{u}$-ED2A $\rightarrow \mathrm{N}$-methyl ethylenediaminemonoacetate

$\mathrm{s}-\mathrm{ED} 2 \mathrm{~A} \rightarrow \mathrm{N}$-methyl ethylenediaminemonoacetate

s-ED2A $\rightarrow$ ED1A

s-ED2A $\rightarrow$ IDA + G

$\mathrm{s}-\mathrm{ED} 2 \mathrm{~A} \rightarrow \mathrm{N}-\mathrm{MeG}$

NTA $\rightarrow$ N-MeIDA

$\mathrm{NTA} \rightarrow$ IDA + G

IDA $\rightarrow \mathrm{N}-\mathrm{MeG}$

IDA $\rightarrow \mathbf{G}$

$\mathrm{G} \rightarrow$ Oxalate, Formate, Carbonate 
Table 3-2. Relative Rates of Disappearance of Organic Complexants and Selected Derivatives During Radiolysis of Simulants at $20^{\circ} \mathrm{C}$ or $25^{\circ} \mathrm{C}$.

\begin{tabular}{|c|c|c|}
\hline Organic Compound & Relative Rate Per Molecule* & Number of Experiments \\
\hline EDTA & $6 \pm 2$ & 20 \\
\hline HEDTA & $13 \pm 6$ & 9 \\
\hline u-EDDA & $3 \pm 3$ & 3 \\
\hline s-EDDA & $13 \pm 2$ & 7 \\
\hline NTA & $8 \pm 2$ & 7 \\
\hline IDA & $12 \pm 3$ & 3 \\
\hline Glycinate & $7 \pm 1$ & 3 \\
\hline Glycolate & $5 \pm 1$ & 8 \\
\hline Formate & 1.00 & \\
\hline Citrate & $0.6 \pm 0.2$ & 8 \\
\hline Acetate & $0.4 \pm 0.4$ & 3 \\
\hline
\end{tabular}

Note: Information in this table is from:

- Camaioni, D. M., W. D. Samuels, J. C. Lenihan, A. K Sharma, M. O. Hogan, M. A. Lilga, S. A Clauss, K. L. Wahl, and J. A. Campbell, 1997, Organic Tanks Safety Program FY 97 Waste Aging Studies, PNNL-10794, Pacific Northwest National Laboratory, Richland, Washington.

- Camaioni, D. M., W. D. Samuels, J. C. Lenihan, A. K. Sharma, S. T. Autrey, M. A. Lilga, M. O. Hogan, S. A. Clauss, K. L. Wahl, and J. A. Campbell, 1998, Organic Tanks Safety Program Waste Aging Studies Final Report, PNNL-11909, Pacific Northwest National Laboratory, Richland, Washington.

*The value for formate ion is adopted as 1.0 .

EDTA = ethylenediaminetetraacetate ion. NTA $=$ nitrilotriacetate ion.

HEDTA $=$ hydroxyethylethylenediaminetriacetate ion. $s-E D D A=$ symmetrical-ethylenediaminediacetate ion.

IDA = iminodiacetate ion. u-EDDA $=$ unsymmetrical-ethylenediaminediacetate ion.

The nitrogen-containing members of the EDTA family are between 6 and 13 times more reactive than formate ion. Glycolate ion is also more reactive than formate ion, but citrate and acetate ion are less reactive. The most reactive compounds are about 35 times more reactive than the least reactive compound investigated. In addition, Meisel and Camaioni (1998) found that nitrogen dioxide reacts more rapidly with glycinate ion than formate ion and that nitrogen dioxide reacted more rapidly with IDA, NTA, and glycinate ion than with formate ion (Meisel et al. 2000).

The range of reactivity observed in the work with simulants is smaller than the range of reactivity exhibited by the complexants toward hydrogen atoms, hydroxyl radicals, or oxygen anion radical in alkaline solution. The results for the reactions with hydrogen atom are summarized in Table 3-3.

The differences are in accord with the concept that waste chemistry is not dominated by the radicals produced through the radiolysis of water but rather by the reactions of oxidizing radicals such as nitric oxide and nitrogen dioxide. 
Table 3-3. Relative Reactivity of Organic Compounds in Hydrogen Atom Abstraction Reactions in Homogeneous Alkaline Aqueous Solution at $25^{\circ} \mathrm{C}$.

\begin{tabular}{|c|c|}
\hline Compound or Anion & Relative Rate Per Molecule* \\
\hline HEDTA & 4.0 \\
\hline EDTA & 4.0 \\
\hline Cyclohexane & 2.0 \\
\hline Formate & 1.0 \\
\hline Butanol & 0.7 \\
\hline Glycolate & 0.4 \\
\hline Butyrate & 0.3 \\
\hline Succinate & 0.2 \\
\hline Acetate & 0.02 \\
\hline Citrate & 0.01 \\
\hline Oxalate & 0.001 \\
\hline
\end{tabular}

*The rate constants used to evaluate the relative rates of reaction are from Buxton, G. V., W. P. Greenstock, W. P. Helman, and A. B. Ross, 1988, "Critical Review of Rate Constants for Reactions of Hydrated Electrons, Hydrogen Atoms, and Hydroxyl Radicals in Aqueous Solution," J. Phys. Chem. Ref. Data, Vol. 17, p. 513.

EDTA $=$ ethylenediaminetetraacetate ion.

HEDTA = hydroxyethylethylenediaminetriacetate ion.

\subsubsection{Product Distributions and Relative Rates for Solvents}

3.2.2.1 Products. No targeted investigations were needed to define the products of the thermal reactions of the solvent molecules because the rates of the thermal reactions of the hydrocarbons are very slow and because the products of the thermal, hydrolytic reactions of the phosphate esters are very well established in the chemical literature (Cox and Ramsey 1964; Wolfenden et al. 1998). Trialkyl, dialkyl, and monoalkyl phosphates hydrolyze to liberate an alcohol and a less alkylated phosphate as shown in the equations:

$$
\begin{gathered}
\left(\mathrm{R}_{1} \mathrm{O}\right)_{3} \mathrm{PO}+\mathrm{NaOH} \rightarrow\left(\mathrm{R}_{1} \mathrm{O}\right)_{2} \mathrm{P}(=\mathrm{O}) \mathrm{ONa}+\mathrm{R}_{1} \mathrm{OH} \\
\left(\mathrm{R}_{1} \mathrm{O}\right)_{2} \mathrm{P}(=\mathrm{O}) \mathrm{ONa}+\mathrm{NaOH} \rightarrow\left(\mathrm{R}_{1} \mathrm{O}\right) \mathrm{P}(=\mathrm{O})(\mathrm{ONa})_{2}+\mathrm{R}_{1} \mathrm{OH} \\
\left(\mathrm{R}_{1} \mathrm{O}\right) \mathrm{P}(=\mathrm{O})(\mathrm{ONa})_{2}+\mathrm{NaOH} \rightarrow \mathrm{Na}_{3} \mathrm{PO}_{4}+\mathrm{R}_{1} \mathrm{OH}
\end{gathered}
$$

where " $R_{1}$ " represents either the butyl or 2-ethylhexyl group.

The hydrolysis of TBP forms 1-butanol, DBP, and monobutylphosphate ion (MBP) and phosphate ion. Sodium bis(2-ethylhexyl)phosphate forms 2-ethylhexanol and (2-ethylhexyl)phosphate ion and phosphate ion. The product distributions obtained in the radiolytic reactions of the phosphate esters have been investigated by several research teams because of their importance in the plutonium-uranium extraction (PUREX) process (Davis 1984). In targeted work, Camaioni et al. (1996a) investigated the radiolysis of DBP in alkaline solution in the presence and absence of sodium nitrate and sodium nitrite. 
The observations for DBP $(\boldsymbol{\bullet}), \operatorname{MBP}(\boldsymbol{\square})$, phosphate $(\bullet)$, other dialkyl phosphates $(\boldsymbol{\Delta})$, and other monoalkyl phosphates ( $)$ are shown in Figure 3-4.

Figure 3-4. Reaction Profile for the Radiolysis of Dibutyl Phosphate.

(Camaioni et al. 1996a)

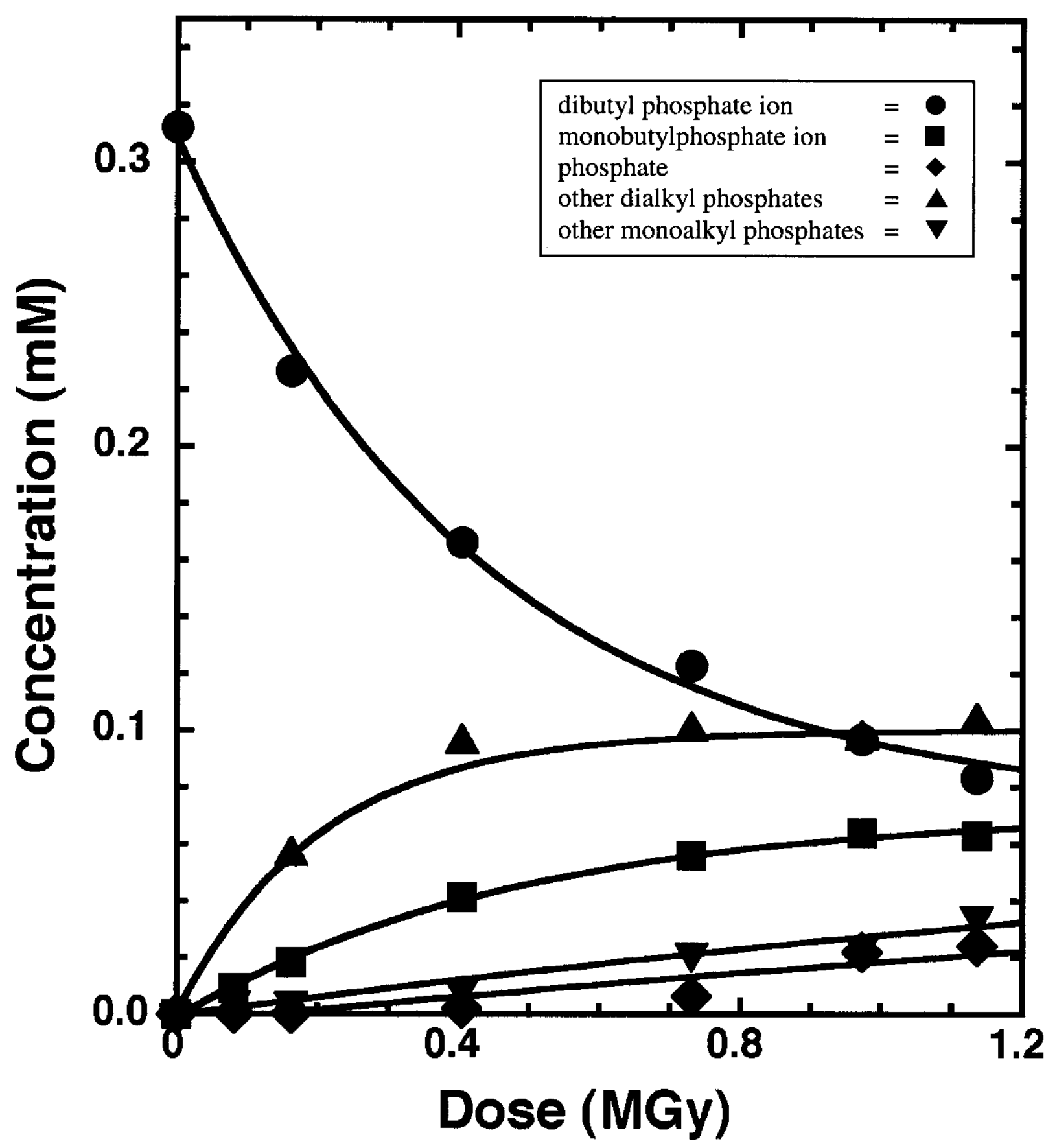

Camaioni et al. (1996a) accounted for phosphorous quantitatively and showed the product mixture contained residual DBP together with MBP, phosphate ion, and families of new dialkyl and monoalkyl phosphates shown in Figure 3-5. 
Figure 3-5. Phosphorous-Based Product Mixtures.

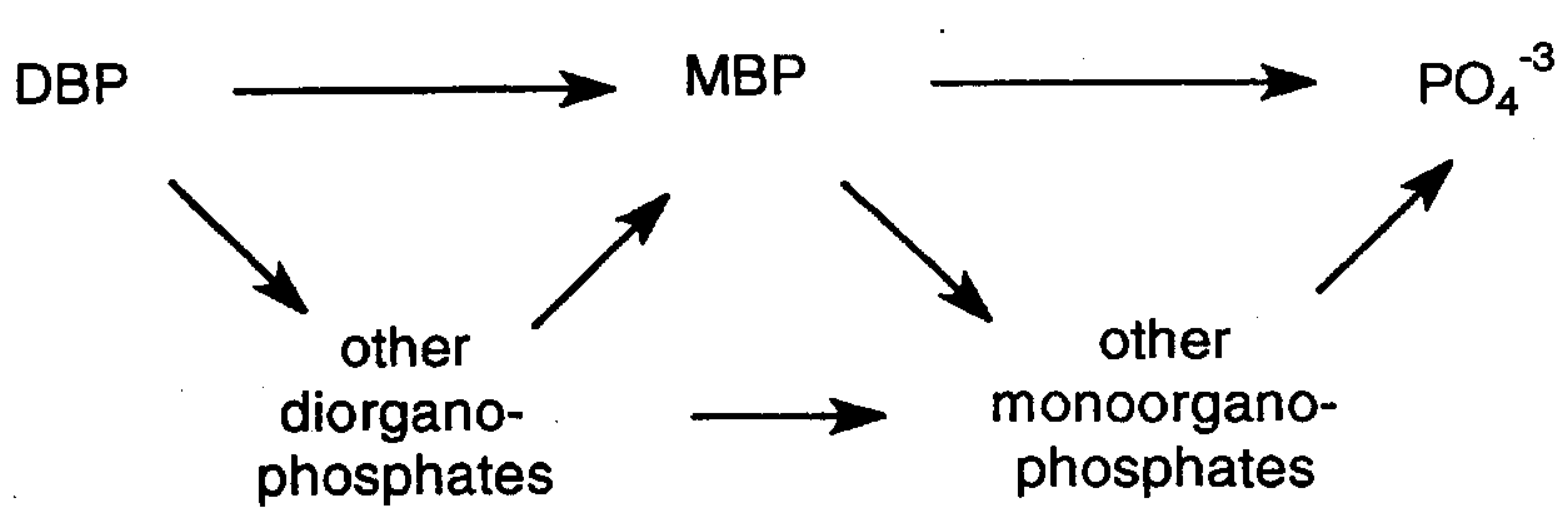

The new dialkyl and monoalkyl phosphates are derivatives of the original phosphates formed by the introduction of hydroxyl or carbonyl groups into the butyl groups of DBP and MBP during radiolysis. Two of the possible products are shown:

$$
\begin{gathered}
\left(\mathrm{CH}_{3} \mathrm{CH}_{2} \mathrm{CH}_{2} \mathrm{CH}(\mathrm{OH}) \mathrm{O}\right)(\mathrm{BuO}) \mathrm{P}(=\mathrm{O}) \mathrm{ONa} \\
\left(\mathrm{CH}_{3} \mathrm{CH}_{2} \mathrm{CH}_{2} \mathrm{C}(=\mathrm{O}) \mathrm{O}\right)(\mathrm{BuO}) \mathrm{P}(=\mathrm{O}) \mathrm{ONa}
\end{gathered}
$$

Camaioni et al. (1996a) also detected sodium acetate, formate, and oxalate among the reaction products, but the sum of the carbon contained in these products and in the phosphates was smaller than the amount of carbon in the starting material. This difference originates because alkanes and alkenes are also formed. Davis (1984) pointed out that the radiolysis of TBP produced methane, ethane, and propane and ethene and propene.

Camaioni et al. (1996a) also investigated the radiolysis of 1-butanol and sodium butyrate, two known reaction products, under the same conditions. These substances decomposed much more rapidly than the phosphate esters. The product mixture contained residual 1-butanol together with sodium formate, acetate, and propionate as well as sodium malate, malonate, and oxalate. These oxidized products account for less than $50 \%$ of the available carbon. Although the other products were not identified, related work described by Spinks and Woods (1990) established that inorganic carbonate ion is produced and that other oxidized and fragmented organic molecules are formed. They point out the radiolysis of low molecular weight alcohols in water and in other media provides high yields of hydrogen and the corresponding aldehyde, and lower yields of alkanes, cycloalkanes, alkenes and alkynes, and other oxygen-containing compounds. The information in the literature identifies MBP, DBP, TBP and 1-butanol as important sources of the fragmented molecules known to be in the wastes (i.e., methane, ethane, propane, butane, ethene, propene, the butenes, cyclopropane, butadiene, ethyne, propyne, the butynes, methanol, ethanol, 1-propanol and 2-propanol, butanal, acetone, and 2-butanone).

The products of the radiolysis reactions of the hydrocarbons have not been investigated in targeted studies because sufficient information is available in the chemical literature (Gyorgy 1981; Davis 1984; Spinks and Woods 1990; Tabata et al. 1991; Bugaenko et al. 1993) to guide the interpretation of the results obtained in the characterization program. In brief, the 


\section{RPP-6664 REV 0}

radiolysis of pure paraffinic hydrocarbons yields fragmented molecules and dimers together with hydrogen and other low molecular weight compounds. When the reactions are carried out in the presence of low concentrations of oxygen, the product spectrum changes and radiolysis provides fragmented alkanes and alkenes and oxidized molecules including alcohols, aldehydes and ketones, and carboxylic acids.

3.2.2.2 Relative Rates. Attempts to determine the relative reactivities of the paraffinic hydrocarbons quantitatively under the heterogeneous conditions prevailing in the waste tanks have not been completely successful (Camaioni et al. 1995, 1996b). However, the following relative reactivity pattern was observed in six experiments in which the recovery of dodecane was complete (Camaioni et al. 1996b):

\section{EDTA $>$ Stearate Ion $>>$ Dodecane}

This observation and the other work on sodium butyrate mentioned subsequently imply sodium butryate and sodium stearate and other soluble, hydrogen-rich sodium salts of the monocarboxylic acids undergo radiolysis under the conditions of interim storage, but that water-insoluble compounds, like dodecane, are much less reactive.

Much greater success has been realized in the investigations of the hydrolytic and radiolytic reactions of the phosphates. The chemical literature indicates that the rate constants for hydrolysis of dialkyl esters are several orders of magnitude smaller than the rate constants for the hydrolysis of the corresponding trialkyl esters, and the rate constants for the hydrolysis of monoalkyl esters are also several orders of magnitude smaller than the rate constants for the dialkyl esters (Cox and Ramsay 1964; Wolfenden et al. 1998). The rates of hydrolysis of TBP have been measured under heterogeneous conditions in the presence of $1 M$ sodium hydroxide at temperatures from $30^{\circ} \mathrm{C}$ to $100^{\circ} \mathrm{C}$ by Burger (1955). The observed rate data were fit to the following expression by Camaioni et al. (1996a:

$$
\ln (R)=54.8-2.55 \times 10^{4}(1 / T)+2.69 \times 10^{6}(1 / T)^{2}
$$

where " $T$ " is the temperature in $K$ and " $R$ " is the rate in milligrams of TBP hydrolyzed per liter per hour. The rate of disappearance of TBP was approximately $15 \mathrm{mg} / \mathrm{h}$ per liter of $1 M$ sodium hydroxide at $65^{\circ} \mathrm{C}$. The reaction rate was about $60 \%$ slower when kerosene, a simulant for the $\mathrm{NPH}$, was added to the reaction system. The slow reaction in the presence of kerosene can be reasonably attributed to the fact that TBP dissolves in kerosene, where, in the absence of hydroxide ion, hydrolysis does not occur. Camaioni et al. (1996a) investigated the hydrolysis of TBP and found sodium, calcium, iron (II), chromium (III), nickel, lead (II), zirconium (IV), nitrate, aluminate, and stearate ions had no appreciable influence on the reaction rate.

The rates of the hydrolytic reactions of the trialkyl and dialkyl phosphate esters differ greatly. The chemical literature and targeted investigations by Burger (1995) establish dialkyl phosphates like DBP and bis(2-ethylhexyl)phosphate react very slowly with water or sodium hydroxide.

The relative rates of the radiolytic reactions of butanol, sodium butyrate, sodium DBP, and sodium EDTA have been established. Camaioni et al. (1996a) showed that in simulants

$$
\text { Butanol }>\text { Butyrate }>\text { DBP }>\text { EDTA }
$$




\section{RPP-6664 REV 0}

The relative reactivity of sodium bis(2-ethylhexyl)phosphate has not been established. However, oil isolated from a layer of sludge in tank 241-C-106 contained

NPH/TBP/(2-ethylhexylphosphoric acid) in a ratio of 5/10/85 compared with a ratio of 40/28/4 in the original process solvent (Stauffer and Stock 1999). These observations also imply that there is a major difference between the radiolytic reactivity of bis(2-ethylhexyl)phosphate and the three butylphosphates. This difference apparently arises from the very low solubility of sodium bis(2-ethylhexyl)phosphate in aqueous solution.

In summary, the rate of hydrolysis of TBP in alkaline solution is sufficient to alter its concentration during interim storage, but the rates of hydrolysis of the dialkyl phosphate ions, DBP and bis(2-ethylhexyl)phosphate, and the monoalkyl phosphate ions, MBP and (2-ethylhexyl)phosphate, are negligible in the aqueous phase of the waste. The rates of radiolysis of the butanol and DBP, the two abundant products of hydrolysis, are larger than the rate of radiolytic decomposition of EDTA. Although direct evidence is lacking, sodium bis(2-ethylhexyl)phosphate apparently undergoes radiolysis much more slowly than the other compounds.

\subsection{REACTION PATHWAYS FOR ORGANIC OXIDATION}

Chemical reaction models and a quantitative kinetic reaction model are presented in this section to describe the oxidation reactions and to underpin the discussion of gas formation in Section 4.0. The radical reactions are discussed before the ionic organic reactions because many of the compounds produced through thermally or radiolytically initiated radical reactions are subsequently decomposed in the ionic processes.

\subsubsection{Radiolytic and Thermal Initiation}

The work with simulants and wastes indicates that the complexants oxidize by thermal and radiolytic processes. The chemical entities responsible for the initiation of the radiolysis reactions are well known and will be described as a prelude to the discussion of the initiation of the thermal reactions.

The radiation chemistry of the Hanford Site wastes is dictated by the relatively high concentrations of cesium- 137 and strontium- 90 . The alpha particle-producing nuclides are not abundant and their contribution to the radiation chemistry is small. Cesium-137 exists predominantly in aqueous solution and strontium-90 in insoluble sludges. These substances undergo radioactive decay producing beta and gamma radiation and electrons through several different reaction channels. The maximum energies associated with the more abundant beta and gamma particles are shown in the following equations (Spinks and Woods 1990; Meisel et al. 1993; Grove Engineering 1987):

$$
\begin{aligned}
& \text { strontium-90 } \rightarrow \text { yttrium-90 + beta }(0.546 \mathrm{eV}) \\
& \text { yttrium-90 } \rightarrow \text { zirconium- } 89+\text { beta }(2.284 \mathrm{eV})
\end{aligned}
$$




$$
\begin{gathered}
\text { cesium }-137 \rightarrow \text { barium }-137 \mathrm{~m}+2 \text { beta }(0.512 \mathrm{eV} \text { and } 1.173 \mathrm{eV}) \\
\text { barium }-137 \mathrm{~m} \rightarrow \text { barium }-137+5 \text { gamma }+5 \text { electrons }
\end{gathered}
$$

Strontium- 90 with a half life of 28 years emits a $0.546 \mathrm{MeV}$ beta particle having an average energy of $0.196 \mathrm{MeV}$, and the short-lived daughter yttrium-90 emits a $2.284 \mathrm{MeV}$ beta particle having an average energy of $0.934 \mathrm{MeV}$. The average energy deposited per disintegration is $1.13 \mathrm{MeV}$.

Cesium-137 with a half life of 30 years decays via two beta emissions. One occurs with a probability of 0.946 and has a maximum energy of $0.512 \mathrm{MeV}$ and an average energy of $0.157 \mathrm{MeV}$, and the other occurs with a probability of 0.054 and has a maximum energy of $1.173 \mathrm{MeV}$ and an average energy of $0.415 \mathrm{MeV}$. The average energy deposited during these two disintegration is $0.171 \mathrm{MeV}$.

The daughter barium-137m has a complex decay pattern yielding five gamma particles and five electrons. Most of the energy is obtained from a gamma emission pathway having a probability of 0.90 and an average energy of $0.662 \mathrm{MeV}$ and an electron emission pathway having a probability of 0.081 and an average energy of $0.624 \mathrm{MeV}$. The average energy deposited per disintegration is $0.630 \mathrm{MeV}$.

The average energy deposited per disintegration of cesium-137 and barium-137m is $0.85 \mathrm{MeV}$ according to Meisel et al. (1993) whereas the Grove Engineering (1987) projects the value to be $0.80 \mathrm{MeV}$.

Beta and gamma radiation at the energy emitted by cesium-137 and strontium- 90 have essentially the same consequences (Meisel et al. 1991a, 1991b, 1993), and the chemistry of the process can be investigated conveniently by using cobalt- 60 sources. The emitted particles transfer energy to water, producing electronically excited water molecules and ion pairs in widely separated spurs. The reaction cascade results in the prompt formation of solvated electrons, hydrogen atoms, and hydroxyl radicals in the initial reactions:

$$
\mathrm{H}_{2} \mathrm{O} \rightarrow \mathrm{e}\left(\mathrm{H}_{2} \mathrm{O}\right)+\mathrm{H}+\mathrm{OH}
$$

Gases are also generated and the organic constituents are oxidized when simulants and representative samples of the waste are heated in the absence of radiation. These thermal decomposition reactions proceed by free radical reactions and by ionic processes. It is relatively easy to isolate and to identify the chemical processes responsible for the ionic reactions. To illustrate, the high concentration of hydroxide ions in the waste is a major factor in the promotion of the ionic decomposition reactions of citrate ions in the absence of radiation, and the high concentrations of hydroxide and aluminate ions are important for the ionic decomposition of glycolate ions in the absence of radiation. These ionic processes are not sensitive to the concentration of oxygen and have significant activation energies.

The evidence for the occurrence of thermally initiated free radical processes is less direct, but it is compelling. First, thermal gas formation reactions have relatively high activation energies, implying that bond-breaking, free radical-forming reactions are required for initiation (Bryan and Pederson, 1994, 1995; Bryan et al. 1996, 1997; Person 1996, 1998). Second, the rates and product distribution observed for thermal reactions of complexants in simulants are very 
sensitive to oxygen (Barefield et al. 1995, 1996; Person 1996, 1998; Camaioni et al. 1995, 1996b, 1997, 1998). Ionic reactions are not usually sensitive to the oxygen content. Third, the reactions of nitrite ions often lead to the formation of radicals, including nitric oxide and nitrogen dioxide. These substances are known to be effective oxidants in the radiolytic reactions of the complexants and solvents. These considerations strongly suggest that the thermal reactions occur through radical processes that involve nitrite ion as well as through the ionic reactions outlined in the previous paragraphs.

3.3.1.1 A Quantitative Kinetic Model for the Initial Reactions. The rate constants for many elementary free radical reactions have been measured during the past 50 years. Many rate data have been critically examined and summarized by Buxton et al. (Buxton et al. 1988). In addition to this body of knowledge, targeted investigations (Meisel et al. 1991a, 1991b, 1993, 1997; Camaioni et al. 1995, 1996b, 1997, 1998; Camaioni and Autrey 2000; Fessenden et al. 2000) have provided the information necessary to construct a kinetic model to describe chemical transformations of the hydrogen atoms, hydroxyl radicals, and solvated electrons produced from the radiolysis of water in alkaline solutions with high concentrations of sodium nitrite and sodium nitrate. The quantitative kinetic reaction model, which remains under development and has been extended to describe the oxidation of formate and glycinate ion, includes more than 30 different chemical reactions, as shown in Table 3-4.

The model indicates the chemical composition is dictated by the rapid destruction of the hydrogen atoms and nitrate dianions, and these substances are rapidly replaced by oxidizing radicals, including nitric oxide and nitrogen dioxide. Hydrogen atom reacts rapidly with nitrite ion to form nitric oxide, and the solvated electron reacts with the nitrate ion to yield the dianion of nitrogen trioxide, which rapidly decomposes to form nitrogen dioxide:

$$
\begin{array}{ll}
\mathrm{H}+\mathrm{NO}_{2}^{-} \rightarrow \mathrm{NO}+\mathrm{OH}^{-} & \mathrm{k}=1.6 \times 10^{9} \mathrm{M}^{-1} \mathrm{~s}^{-1} \\
\mathrm{e}(\mathrm{aq})^{-}+\mathrm{NO}_{3}{ }^{-} \rightarrow \mathrm{NO}_{3}{ }^{2-} & \mathrm{k}=9.7 \times 10^{9} \mathrm{M}^{-1} \mathrm{~s}^{-1} \\
\mathrm{NO}_{3}{ }^{2-}+\mathrm{H}_{2} \mathrm{O} \rightarrow \mathrm{NO}_{2}+2 \mathrm{OH}^{-} & \mathrm{k}=5.5 \times 10^{4} \mathrm{~s}^{-1}
\end{array}
$$

where " $\mathrm{k}$ " is the reaction rate constant.

The half-life of the nitrate dianion in water is approximately 15 microseconds. However, the nitrate dianion is considerably more stable in alkaline solutions because of the favorable equilibrium constant for the reaction between the hydroxide ion and nitrogen dioxide (Meisel et al. 2000; Fessenden et al. 2000):

$$
2 \mathrm{HO}^{-}+\mathrm{NO}_{2} \rightarrow \mathrm{NO}_{3}{ }^{2-}+\mathrm{H}_{2} \mathrm{O}
$$

The substance is consumed in reactions with nitrogen dioxide and nitric oxide:

$$
\begin{gathered}
\mathrm{NO}_{3}{ }^{2-}+\mathrm{NO}_{2} \rightarrow \mathrm{NO}_{2}{ }^{-}+\mathrm{NO}_{3}{ }^{-} \\
\mathrm{NO}_{3}{ }^{2-}+\mathrm{NO} \rightarrow 2 \mathrm{NO}_{2}^{-}
\end{gathered}
$$


Table 3-4. Kinetic Reaction Model for Radiolysis in Aqueous Alkaline Solutions of Sodium Nitrite. (2 sheets)

\begin{tabular}{|c|c|c|c|c|}
\hline $\begin{array}{l}\text { Equation } \\
\text { Number }\end{array}$ & Reactants & Products & $\mathbf{k}\left(\mathrm{s}^{-1}\right)$ & Note \\
\hline 1 & & $\mathrm{NO}_{3}{ }^{2-}$ & $4.9 \times 10^{-7}$ & 2 \\
\hline 2 & & $\mathrm{OH}$ & $5.2 \times 10^{-7}$ & 2 \\
\hline 3 & & $\mathrm{H}$ & $1.0 \times 10^{-7}$ & 2 \\
\hline 4 & $\mathrm{NO}_{3}{ }^{2-}+\mathrm{H}_{2} \mathrm{O}$ & $\mathrm{NO}_{2}+{ }_{2} \mathrm{OH}^{-}$ & $5.5 \times 10^{4}$ & 3 \\
\hline 5 & $\mathrm{NO}_{3}^{2-}+\mathrm{NO}_{2}^{-}\left(+\mathrm{H}_{2} \mathrm{O}\right)$ & $\mathrm{NO}+\mathrm{NO}_{3}{ }^{-}\left({ }^{2}{ }_{2} \mathrm{OH}^{-}\right)$ & $2.0 \times 10^{4}$ & 4,5 \\
\hline 6 & $\mathrm{OH}+\mathrm{OH}^{-}$ & $\mathrm{O}^{-}+\mathrm{H}_{2} \mathrm{O}$ & $1.3 \times 10^{10}$ & 5 \\
\hline 7 & $\mathrm{OH}+\mathrm{NO}_{2}^{-}$ & $\mathrm{NO}_{2}+\mathrm{OH}^{-}$ & $1.0 \times 10^{10}$ & 3 \\
\hline 8 & $\mathrm{OH}+\mathrm{HCO}_{2}^{-}$ & $\mathrm{CO}_{2}^{-}+\mathrm{H}_{2} \mathrm{O}$ & $4.1 \times 10^{9}$ & 3 \\
\hline 9 & $\mathrm{H}+\mathrm{NO}_{2}^{-}$ & $\mathrm{NO}+\mathrm{OH}^{-}$ & $1.6 \times 10^{9}$ & 3,7 \\
\hline 10 & $\mathrm{H}+\mathrm{HCO}_{2}^{-}$ & $\mathrm{CO}_{2}^{-}+\mathrm{H}_{2}$ & $2.4 \times 10^{8}$ & 3 \\
\hline 11 & $\mathrm{O}^{-}+\mathrm{NO}_{2}^{-}\left(+\mathrm{H}_{2} \mathrm{O}\right)$ & $\mathrm{NO}_{2}+\mathrm{OH}^{-}\left(+\mathrm{OH}^{-}\right)$ & $3.1 \times 10^{8}$ & 3 \\
\hline 12 & $\mathrm{O}^{-}+\mathrm{HCO}_{2}^{-}$ & $\mathrm{CO}_{2}^{-}+\mathrm{OH}^{-}$ & $1.4 \times 10^{9}$ & 3 \\
\hline 13 & $\mathrm{NO}_{2}+\mathrm{HCO}_{2}^{-}$ & $\mathrm{CO}_{2}^{-}+\mathrm{NO}_{2}^{-}\left(+\mathrm{H}^{+}\right)$ & $1.0 \times 10^{1}$ & 5 \\
\hline 14 & $\mathrm{CO}_{2}^{-}+\mathrm{NO}_{2}^{-}\left(+\mathrm{H}_{2} \mathrm{O}\right)$ & $\mathrm{CO}_{2}^{-}+\mathrm{NO}\left({ }_{2} \mathrm{OH}^{-}\right)$ & $4.3 \times 10^{6}$ & 6 \\
\hline 15 & $\mathrm{CO}_{2}^{-}+\mathrm{NO}_{2}$ & $\mathrm{NO}_{2}^{-}+\mathrm{CO}_{2}$ & $3.0 \times 10^{9}$ & 9 \\
\hline 16 & $\mathrm{CO}_{2}^{-}+\mathrm{NO}$ & $\mathrm{CO}_{2}+\mathrm{NO}^{-}$ & $2.9 \times 10^{9}$ & 10 \\
\hline 17 & $\mathrm{NO}_{2}+\mathrm{NO}_{2}$ & $\mathrm{~N}_{2} \mathrm{O}_{4}$ & $4.5 \times 10^{8}$ & 11 \\
\hline 18 & $\mathrm{~N}_{2} \mathrm{O}_{4}$ & $\mathrm{NO}_{2}+\mathrm{NO}_{2}$ & $6.7 \times 10^{3}$ & 11 \\
\hline 19 & $\mathrm{~N}_{2} \mathrm{O}_{4}\left(+_{2} \mathrm{OH}^{-}\right)$ & $\mathrm{NO}_{2}^{-}+\mathrm{NO}_{3}^{-}\left(+\mathrm{H}_{2} \mathrm{O}\right)$ & $1.0 \times 10^{3}$ & 11 \\
\hline 20 & $\mathrm{NO}_{2}+\mathrm{NO}$ & $\mathrm{N}_{2} \mathrm{O}_{3}$ & $1.1 \times 10^{9}$ & 11 \\
\hline 21 & $\mathrm{~N}_{2} \mathrm{O}_{3}$ & $\mathrm{NO}_{2}+\mathrm{NO}$ & $8.0 \times 10^{4}$ & 11 \\
\hline 22 & $\mathrm{~N}_{2} \mathrm{O}_{3}+\left(+{ }_{2} \mathrm{OH}^{-}\right)$ & $\mathrm{NO}_{2}^{-}+\mathrm{NO}_{2}^{-}\left(+\mathrm{H}_{2} \mathrm{O}\right)$ & $5.3 \times 10^{2}$ & 11 \\
\hline 23 & $\mathrm{NO}^{-}+\mathrm{NO}$ & $\mathrm{N}_{2} \mathrm{O}_{2}^{-}$ & $1.7 \times 10^{9}$ & 11 \\
\hline 24 & $\mathrm{~N}_{2} \mathrm{O}_{2}^{-}$ & $\mathrm{NO}^{-}+\mathrm{NO}$ & $6.0 \times 10^{4}$ & 11 \\
\hline 25 & $\mathrm{~N}_{2} \mathrm{O}_{2}^{-}+\mathrm{NO}$ & $\mathrm{N}_{3} \mathrm{O}_{3}^{-}$ & $4.9 \times 10^{6}$ & 11 \\
\hline 26 & $\mathrm{~N}_{3} \mathrm{O}_{3}{ }^{-}$ & $\mathrm{N}_{2} \mathrm{O}+\mathrm{NO}_{2}$ & $8.7 \times 10^{1}$ & 11 \\
\hline 27 & $\mathrm{H}+\mathrm{OH}^{-}$ & $\mathrm{e}^{-}(\mathrm{aq})$ & $2.0 \times 10^{7}$ & 4,8 \\
\hline 28 & $\mathrm{e}^{-}(\mathrm{aq})+\mathrm{NO}_{3}$ & $\mathrm{NO}_{3}{ }^{2-}$ & $9.7 \times 10^{9}$ & 3 \\
\hline 29 & $\mathrm{Gly}^{-}+\mathrm{H}$ & $\mathrm{G}-+\mathrm{H}_{2}$ & $4.5 \times 10^{7}$ & 5 \\
\hline 30 & $\mathrm{Gly}^{-}+\mathrm{O}^{-}\left(+\mathrm{H}_{2} \mathrm{O}\right)$ & $\mathrm{I}+{ }_{2} \mathrm{OH}^{-}$ & $5.6 \times 10^{8}$ & 12 \\
\hline 31 & $\mathrm{Gly}^{-}+\mathrm{OH}$ & $\mathrm{I}+\mathrm{OH}^{-}$ & $5.3 \times 10^{9}$ & 13 \\
\hline 32 & $\mathrm{Gly}^{-}+\mathrm{NO}_{2}$ & $\mathrm{I}+\mathrm{NO}_{2}^{-}$ & $7.0 \times 10^{1}$ & 5 \\
\hline 33 & $\mathrm{I}$ & $\mathrm{A}+\mathrm{CO}_{2}$ & $3.0 \times 10^{6}$ & 5 \\
\hline 34 & $\mathrm{I}+\mathrm{OH}^{-}$ & $\mathrm{G}-+\mathrm{H}_{2} \mathrm{O}$ & $5.0 \times 10^{5}$ & 5 \\
\hline 35 & $\mathrm{~A}+\mathrm{NO}_{2}^{-}$ & $\mathrm{NO}^{-}+\mathrm{CH}_{2} \mathrm{O}\left(+\mathrm{NH}_{3}\right)$ & $1.0 \times 10^{6}$ & 5 \\
\hline 35 & $\mathrm{~A}+\mathrm{NO}_{2}$ & $\mathrm{NO}+\mathrm{CH}_{2} \mathrm{O}\left(+\mathrm{NH}_{3}\right)$ & $1.0 \times 10^{6}$ & 5 \\
\hline
\end{tabular}




\section{RPP-6664 REV 0}

Table 3-4. Kinetic Reaction Model for Radiolysis in Aqueous Alkaline Solutions of Sodium Nitrite. (2 sheets)

\begin{tabular}{|c|c|c|c|c|}
\hline $\begin{array}{l}\text { Equation } \\
\text { Number }\end{array}$ & Reactants? & Products & $k\left(s^{1}\right)$ & Note \\
\hline 36 & $\mathrm{~A}+\mathrm{NO}_{2}$ & $\mathrm{NO}+\mathrm{CH}_{2} \mathrm{O}\left(+\mathrm{NH}_{3}\right)$ & $1.0 \times 10^{6}$ & 5 \\
\hline 37 & $\mathrm{G}^{-}+\mathrm{NO}_{2}^{-}$ & $\mathrm{NO}^{+}+\mathrm{OCHCO}_{2}^{-}\left(+\mathrm{NH}_{3}\right)$ & $1.0 \times 10^{6}$ & 5 \\
\hline 37 & $\mathrm{G}+\mathrm{NO}_{2}$ & $\mathrm{NO}+\mathrm{OCHCO}_{2}^{-}\left(+\mathrm{NH}_{3}\right)$ & $1.0 \times 10^{6}$ & 5 \\
\hline
\end{tabular}

Note 1: The reactants that appear in the rate law are shown in the conventional manner; other substances that do not appear in the rate law but are necessary to balance the equation are shown in parentheses. These observations were originally documented in D. M. Camaioni, W. D. Samuels, J. C. Lenihan, S. T. Sharma, A. K. Autrey, M. A. Lilga, M. O. Hogan, S. A. Clauss, K. L. Wahl, and J. A. Campbell, 1998, Organic Tanks Safety Program Waste Aging Studies Final Report, PNNL-1 1909, Pacific Northwest National Laboratory, Richland, Washington.

Note 2: The rate parameters were assigned based on work reported by:

- Buxton, G. V., Greenstock, W. P., Helman, W. P., and A. B. Ross, 1988, "Critical Review of Rate Constants for Reactions of Hydrated Electrons, Hydrogen Atoms, and Hydroxyl Radicals in Aqueous Solution," J. Phys. Chem. Ref. Data, Vol. 17, p. 513.

- Meisel, D., H. Diamond, E. P. Horwitz, C. D. Jonah, M. S. Matheson, M. C. Sauer, Jr., and J. C. Sullivan, 1991a, Radiation Chemistry of Synthetic Waste, ANL-91/40, Argonne National Laboratory, Argonne, Illinois.

- Meisel, D., H. Diamond, E. P. Horwitz, C. D. Jonah, M. S. Matheson, M. C. Sauer, Jr., J. C. Sullivan, F Barnabas, E Cerny, and Y. D. Cheng, 1991b, Radiolytic Generation of Gases from Synthetic Waste, ANL-91/41, Argonne National Laboratory, Argonne, Illinois.

Note 3: Buxton, G. V., Greenstock, W. P., Helman, W. P., and A. B. Ross, 1988, "Critical Review of Rate Constants for Reactions of Hydrated Electrons, Hydrogen Atoms, and Hydroxyl Radicals in Aqueous Solution," J. Phys. Chem. Ref. Data, Vol. 17, p. 513.

Note 4: Meisel and coworkers have established the rate constant is $>5 \times 10^{4} \mathrm{M}^{-1} \mathrm{~s}^{-1}$ (Camaioni et al. 1998).

Note 5: The value has been assigned on the basis of experimental work by D. M. Camaioni, W. D. Samuels, J. C. Lenihan, S. T. Sharma, A. K. Autrey, M. A. Lilga, M. O. Hogan, S. A. Clauss, K. L. Wahl, and J. A. Campbell, 1998, Organic Tanks Safety Program Waste Aging Studies Final Report, PNNL-11909, Pacific Northwest National Laboratory, Richland, Washington.

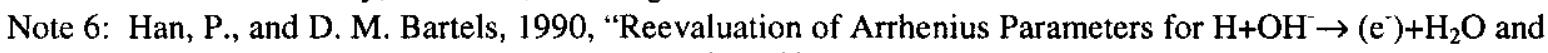
the Enthalpy and Entropy of Hydrated Electrons," J. Phys. Chem., Vol. 94, pp. 7294-7299.

Note 7: Mezyk, S. P. and D. M. Bartels, 1997, "Temperature Dependence of Hydrogen Atom Reaction with Nitrate and Nitrite Species in Aqueous Solution," J. Phys. Chem., A, Vol. 101, pp. 6233-6237.

Note 8: Unpublished work of Meisel and coworkers (Camaioni et al. 1998).

Note 9: Assigned rate constant.

Note 10: Czapski, G., J. Holeman, and B. H. J. Bielski, 1994, "Reactivity of Nitric Oxide with Short-Lived Radicals in Aqueous Solutions," J. Am. Chem. Soc., Vol. 116, pp. 11465-11469.

Note 11: Neta, P., R. E. Huie, and A. B. Ross, 1988, "Rate Constants for Reactions of Inorganic Radicals in Aqueous Solution," J. Phys. Chem. Ref. Data, Vol. 17, pp. 1027-1284.

Note 12: Neta, P., and R. H. Schuler, 1975, "Rate Constants for the Reaction of $\mathrm{O}^{-}$Radicals with Organic Substrates in Aqueous Solutions," J. Phys. Chem., Vol. 79, pp. 1-6.

Note 13: Lati, J., and D. Meyerstein, 1972, "The Reaction of Oxygen Anion Radical with the Aminoacetate Ion," Inorg. Chem., Vol. 11, pp. 2397-2401. 
At elevated $\mathrm{pH}$, the hydroxyl radical reacts with the hydroxide ion to produce water and the oxide anion radical. This anion radical is converted to nitrogen dioxide:

$$
\begin{array}{ll}
\mathrm{OH}+\mathrm{OH}^{-} \rightarrow \mathrm{H}_{2} \mathrm{O}+\mathrm{O}^{-} & \mathrm{k}=1.3 \times 10^{10} \mathrm{M}^{-1} \mathrm{~s}^{-1} \\
\mathrm{O}^{-}+\mathrm{NO}_{2}^{-}+\mathrm{H}_{2} \mathrm{O} \rightarrow \mathrm{NO}_{2}+2 \mathrm{OH}^{-} & \mathrm{k}=3.1 \times 10^{8} \mathrm{M}^{-1} \mathrm{~s}^{-1}
\end{array}
$$

At lower $\mathrm{pH}$, the hydroxyl radical reacts with nitrite ion to give nitrogen dioxide:

$$
\mathrm{OH}+\mathrm{NO}_{2}^{-} \rightarrow \mathrm{NO}_{2}+\mathrm{OH}^{-} \quad \mathrm{k}=1.0 \times 10^{10} \mathrm{M}^{-1} \mathrm{~s}^{-1}
$$

As a consequence of high sodium nitrite and sodium nitrate concentrations, the original very reactive components produce two oxidizing agents, nitric oxide and nitrogen dioxide. As shown in the equations, these substances recombine to give anhydrides that hydrolyze in aqueous solution to form nitrite or nitrate ion:

$$
\begin{gathered}
2 \mathrm{NO}_{2} \rightarrow \mathrm{N}_{2} \mathrm{O}_{4} \\
\mathrm{~N}_{2} \mathrm{O}_{4}+2 \mathrm{OH}^{-} \rightarrow \mathrm{NO}_{2}^{-}+\mathrm{NO}_{3}^{-}+\mathrm{H}_{2} \mathrm{O} \\
\mathrm{NO}+\mathrm{NO}_{2} \rightarrow \mathrm{N}_{2} \mathrm{O}_{3} \\
\mathrm{~N}_{2} \mathrm{O}_{3}+2 \mathrm{OH}^{-} \rightarrow 2 \mathrm{NO}_{2}^{-}+\mathrm{H}_{2} \mathrm{O}
\end{gathered}
$$

These reactions reduce the concentrations of nitric oxide and nitrogen dioxide, but analysis of the kinetics of the competitive processes indicates the steady-state concentrations of these oxidizing radicals are more than sufficient to dictate the chemistry.

Extensive information about the radiolysis of water provides a sound technical basis for the establishment of the rate constants for the initiation reactions in the model. There is much less information available about the thermal chemistry of nitrite ion under the complex reaction conditions applicable for Hanford Site wastes. The free radical reaction and the ionic reactions occur competitively, but pathways of initiation of the free radical reactions have not been established, and the thermal reaction has not been explicitly modeled. However, the thermally initiated radical process is, like radiolysis, an oxidation reaction, and in the absence of definite evidence, it is reasonable to postulate that nitric oxide and nitrogen dioxide also participate in the thermally initiated processes. Thus, although the initiation reactions in the thermal reaction cannot be quantitatively analyzed, the ensuing radiolytic and thermal decomposition reactions are similar.

3.3.1.2 A Quantitative Model for the Oxidation of Formate and Glycinate Ions. The quantitative kinetic reaction model has been extended to include evaluation of the rate of oxidation of formate and glycinate ions (Camaioni et al. 1998; Meisel et al. 2000). The chemical reactions are shown in Figure 3-6.

The reaction model for the oxidation of the formate ion includes abstraction reactions with the hydrogen atom and the hydroxyl radical and its anion. The electron transfer reaction is formulated to proceed exclusively with nitrogen dioxide to yield an anion radical pair that 


\section{RPP-6664 REV 0}

decomposes by proton transfer to yield the anion of carbon dioxide. The rapid reactions in which this anion is converted into carbon dioxide and carbonate ion are not shown in Figure 3-6.

The reaction model for the oxidation of the glycinate ion includes reactions with the same hydrogen abstracting reagents, each of which can form two different radicals. The electron transfer occurs with the hydroxyl radical and nitrogen dioxide to yield two different anion zwitterion pairs. The pairs decompose either to form the same radicals obtained in the abstraction reactions or into the aminomethyl radical and carbon dioxide.

Although the rate constants for the competing reactions of the hydroxyl radical and its anion with the inorganic constituents are very large, the rate constants for their reactions with organic molecules are also very large, as illustrated for the hydrogen atom abstraction reaction of formate ion by hydrogen atom (Buxton et al. 1988) and the electron transfer reaction of hydroxyl radical with glycinate ion (Buxton et al. 1988; Bonifacic' et al. 1998):

$$
\begin{array}{ll}
\mathrm{H}+\mathrm{HCO}_{2}^{-} \rightarrow \mathrm{H}_{2}+\mathrm{CO}_{2}^{-} & \mathrm{k}=1.4 \times 10^{9} \mathrm{M}^{-1} \mathrm{~s}^{-1} \\
\mathrm{OH}+\mathrm{H}_{2} \mathrm{NCH}_{2} \mathrm{CO}_{2}^{-} \rightarrow \mathrm{OH}^{-}+\mathrm{H}_{2} \mathrm{~N}^{+} \mathrm{CH}_{2} \mathrm{CO}_{2}^{-} & \mathrm{k}=5.3 \times 10^{9} \mathrm{M}^{-1} \mathrm{~s}^{-1}
\end{array}
$$

Preliminary tests of the quantitative kinetic reaction model have been carried out. The model successfully explains the experimental observations for the decomposition of formate ion (see Figure 3-7). The experimental datum (Lilga et al. 1996) for the reaction with $0.1 M$ sodium nitrate, $0.03 \mathrm{M}$ sodium nitrite $2.00 \mathrm{M}$ sodium hydroxide is shown by the open circle, and the experimental data (Camaioni et al. 1998) for the reactions with $3.75 \mathrm{M}$ sodium nitrate, $1.25 \mathrm{M}$ sodium nitrite, and $2.00 \mathrm{M}$ sodium hydroxide are shown by closed circles. The agreement between the experimental observations and the predictions of the model shown by the cross in Figure 3-7 is very good.

The kinetic model accounts for the large dependence on the concentrations of sodium nitrite and sodium formate. The large differences in the generation efficiency $(G)$ values shown in Figure 3-7 arise because of differences in the relative concentrations of the reactive radicals. The reaction proceeds predominantly with oxygen anion radicals when the concentrations of formate and nitrite ions are both low. Under other conditions, reactions with hydroxyl radical, oxygen anion radical, and nitrogen dioxide each contribute significantly to the oxidation. The results for the formate ion are compatible with the formulation of the reaction as a competitive process in which several radicals participate in hydrogen atom abstraction reactions and electron transfer reactions.

The kinetic model has also been used to describe the oxidation of the glycinate ion, an important substance produced from the EDTA family of complexants. Recent investigations of the radiolytic reactions of the glycinate ion (Bonifacic' et al. 1998; Camaioni et al. 1998) conclude that the reaction occurs predominantly by electron transfer reactions with the hydroxyl radical and nitrogen dioxide to provide the intermediate anion zwitterion pair shown in Figure 3-6. 
Figure 3-6. Hydrogen Atom Abstraction and Electron Transfer Reactions in Kinetic Model during Radiolysis of Formate and Glycinate Ions in Aqueous Alkaline Solutions of Sodium Nitrite and Sodium Nitrate.

\begin{tabular}{|c|}
\hline $\begin{array}{c}\text { Formate Ion } \\
\text { Through Hydrogen Atom Abstraction } \\
\mathrm{HCO}_{2}^{-}+\mathrm{H} \rightarrow \mathrm{H}_{2}+\mathrm{CO}_{2}^{-} \\
\mathrm{HCO}_{2}^{-}+\mathrm{OH} \rightarrow \mathrm{H}_{2} \mathrm{O}+\mathrm{CO}_{2}^{-} \\
\mathrm{HCO}_{2}^{-}+\mathrm{O}^{-} \rightarrow \mathrm{OH}^{-}+\mathrm{CO}_{2}^{-} \\
\text {Through Electron Transfer } \\
\mathrm{HCO}_{2}^{-}+\mathrm{NO}_{2} \rightarrow \mathrm{ONO}, \mathrm{HCO}_{2} \\
\mathrm{ONO}^{-} \mathrm{HCO}_{2} \rightarrow \mathrm{ONOH}+\mathrm{CO}_{2}^{-}\end{array}$ \\
\hline $\begin{array}{c}\text { Glycinate Ion } \\
\text { Through Hydrogen Atom Abstraction } \\
\mathrm{H}_{2} \mathrm{NCH}_{2} \mathrm{CO}_{2}^{-}+\mathrm{H} \rightarrow \mathrm{H}_{2}+\mathrm{H}_{2} \mathrm{NCHCO}_{2}^{-} \\
\mathrm{H}_{2} \mathrm{NCH}_{2} \mathrm{CO}_{2}^{-}+\mathrm{H} \rightarrow \mathrm{H}_{2}+\mathrm{HNCH}_{2} \mathrm{CO}_{2}^{-} \\
\mathrm{H}_{2} \mathrm{NCH}_{2} \mathrm{CO}_{2}^{-}+\mathrm{OH} \rightarrow \mathrm{H}_{2} \mathrm{O}+\mathrm{H}_{2} \mathrm{NCHCO}_{2}^{-} \\
\mathrm{H}_{2} \mathrm{NCH}_{2} \mathrm{CO}_{2}^{-}+\mathrm{OH} \rightarrow \mathrm{H}_{2} \mathrm{O}+\mathrm{HNCH}_{2} \mathrm{CO}_{2}^{-} \\
\mathrm{H}_{2} \mathrm{NCH}_{2} \mathrm{CO}_{2}^{-}+\mathrm{O}^{-} \rightarrow \mathrm{OH}^{-}+\mathrm{H}_{2} \mathrm{NCHCO}_{2}^{-} \\
\mathrm{H}_{2} \mathrm{NCH}_{2} \mathrm{CO}_{2}^{-}+\mathrm{O}^{-} \rightarrow \mathrm{OH}^{-}+\mathrm{HNCH}_{2} \mathrm{CO}_{2}^{-} \\
\text {Through Electron Transfer }^{-} \\
\mathrm{H}_{2} \mathrm{NCH}_{2} \mathrm{CO}_{2}^{-}+\mathrm{NO}_{2} \rightarrow \mathrm{ONO}^{-}, \mathrm{H}_{2} \mathrm{~N}^{+} \mathrm{CH}_{2} \mathrm{CO}_{2}^{-} \\
\mathrm{ONO}^{-}, \mathrm{H}_{2} \mathrm{~N}^{+} \mathrm{CH}_{2} \mathrm{CO}_{2}^{-} \rightarrow \mathrm{ONOH}^{-}+\mathrm{HNCH}_{2} \mathrm{CO}_{2}^{-} \\
\mathrm{ONO}^{-}, \mathrm{H}_{2} \mathrm{~N}^{+} \mathrm{CH}_{2} \mathrm{CO}_{2}^{-} \rightarrow \mathrm{ONOH}^{-}+\mathrm{H}_{2} \mathrm{NCHCO}_{2}^{-} \\
\mathrm{ONO}^{-}, \mathrm{H}_{2} \mathrm{~N}^{+} \mathrm{CH}_{2} \mathrm{CO}_{2}^{-} \rightarrow \mathrm{NO}_{2}^{-}+\mathrm{H}_{2} \mathrm{NCH}_{2}+\mathrm{CO}_{2} \\
\mathrm{H}_{2} \mathrm{NCH}_{2} \mathrm{CO}_{2}^{-}+\mathrm{OH}^{-} \rightarrow \mathrm{OH}^{-}+\mathrm{H}_{2} \mathrm{~N}^{+} \mathrm{CH}_{2} \mathrm{CO}_{2}^{-} \\
\mathrm{OH}^{-} \mathrm{H}_{2} \mathrm{~N}^{+} \mathrm{CH}_{2} \mathrm{CO}_{2}^{-} \rightarrow \mathrm{H}_{2} \mathrm{O}+\mathrm{HNCH}_{2} \mathrm{CO}_{2}^{-} \\
\mathrm{OH}^{-}, \mathrm{H}_{2} \mathrm{~N}^{+} \mathrm{CH}_{2} \mathrm{CO}_{2}^{-} \rightarrow \mathrm{H}_{2} \mathrm{O}+\mathrm{H}_{2} \mathrm{NCHCO}_{2}^{-} \\
\mathrm{OH}^{-}, \mathrm{H}_{2} \mathrm{~N}^{+} \mathrm{CH}_{2} \mathrm{CO}_{2}^{-} \rightarrow \mathrm{OH}^{-}+\mathrm{H}_{2} \mathrm{NCH}_{2}+\mathrm{CO}_{2}\end{array}$ \\
\hline
\end{tabular}




\section{RPP-6664 REV 0}

Figure 3-7. Comparison of the Experimental Results for the Radiolysis of Formate Ion with the Predictions of a Kinetic Model.

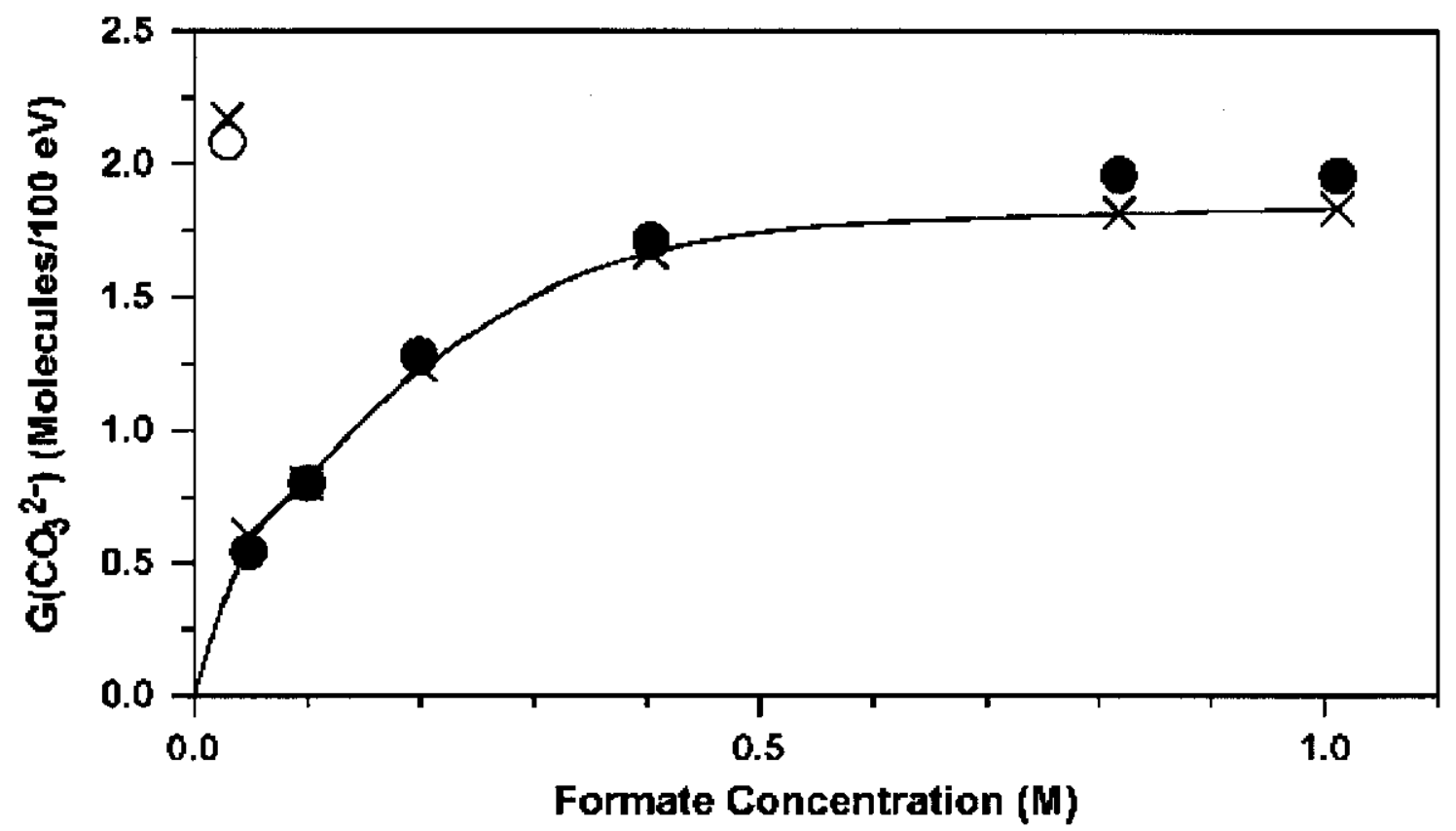

The rate constant for the decomposition of this substance to the aminomethyl radical and carbon dioxide is greater than $10^{8} \mathrm{~s}^{-1}$, however, the rate of conversion of the zwitterion into the nitrogen-centered radical in an acid-base reaction is also very fast. The nitrogen-centered radical is formed in preference to the more thermodynamically stable carbon-centered radical.

The model accounts for the several different observations:

1. The oxidation reactions yield about twice as much formate and carbonate ion as oxalate ion

2. The $\mathrm{G}$ value depends on the sodium nitrite concentration

3. The decomposition of glycinate ion can be initiated by nitrogen dioxide and oxygen anion radical

4. The reaction is more rapid with low concentrations of sodium nitrite

5. Oxygen anion radicals dominate hydrogen abstraction reactions at high concentrations of sodium nitrite.

The results for glycinate ion are compatible with the formulation of the reaction as a competitive process in which several radicals participate in hydrogen atom abstraction and electron transfer reactions.

The concept that two reaction channels, hydrogen atom abstraction and electron transfer, are available for the initiation of the oxidation reactions will be used to formulate a more general 
chemical model for the free radical oxidation reactions of the complexants in the following sections.

\subsubsection{Radical Reactions of the Ethylenediaminetetraacetate Family}

The relative rates of oxidation and the products of the reactions of the EDTA family were discussed in Section 2.1. The most important initiation reactions involving either hydrogen atom abstraction, principally by the hydroxyl radical and its anion, or electron transfer by the hydroxyl radical and nitrogen dioxide were introduced in Section 3.3.1.2. The subsequent reactions leading to product formation are examined in this section. The reactions of glycinate ion, which is structurally the simplest member of the family, are discussed to describe the general reaction patterns of the complexants. The reaction pathways for the NPHs and the phosphate esters are discussed in subsequent sections.

3.3.2.1 Initiation by Hydrogen Atom Abstraction. The hydrogen abstraction reactions from the two possible positions in glycinate ion are shown in the following equations:

$$
\begin{aligned}
& \mathrm{A}+\mathrm{H}_{2} \mathrm{NCH}_{2} \mathrm{CO}_{2}^{-} \rightarrow \mathrm{AH}+\mathrm{H}_{2} \mathrm{NCHCO}_{2}^{-} \\
& \mathrm{A}+\mathrm{H}_{2} \mathrm{NCH}_{2} \mathrm{CO}_{2}^{-} \rightarrow \mathrm{AH}+\mathrm{HNCH}_{2} \mathrm{CO}_{2}{ }^{-}
\end{aligned}
$$

The reagent, "A," represents the entire family of available free radical reagents including the hydrogen atom, hydroxyl radical, oxygen anion radical, nitric oxide, nitrogen dioxide, the carbon-centered and nitrogen-centered radicals in the reaction system, and inorganic substances. The corresponding products, "AH," are hydrogen, water, hydroxide ion, and so forth. The organic products are the nitrogen-centered and carbon-centered derivatives of glycinate ion. The bond dissociation energy of the carbon-hydrogen bond $\left(363 \mathrm{~kJ} \mathrm{~mol}^{-1}\right)$ is much smaller than that of the carbon-nitrogen $\left(406 \mathrm{~kJ} \mathrm{~mol}^{-1}\right)$ bond, and the formation of the carbon-centered radical is the thermodynamically favored reaction.

The kinetic model discussed in the previous section is based on rate constants for the reactions of the hydrogen atom, the hydroxyl radical and its anion, nitric oxide, and nitrogen dioxide. The rate constants for the reaction with the hydrogen atom are large, but the concentration of hydrogen atom is low. Consequently, molecular hydrogen is not produced in abundance by abstraction reactions. On the other hand, the steady-state concentrations and reactivity of the hydroxyl radical and its anion are sufficient to make hydrogen atom abstraction reactions from glycinate ion and the other members of the EDTA family plausible. The rate constants for the abstraction reactions of nitric oxide and nitrogen dioxide with glycinate ion have not been measured, but these constants are certain to be many orders of magnitude smaller than the rate constants for the reactions with the hydrogen atom, hydroxyl radical and its anion, and other carbon-centered and nitrogen-centered organic radicals. The reactions between glycinate ions and other members of the EDTA family with carbon-centered radicals produce carbon-centered radicals (Bonifacic' et al. 1998). The kinetic reaction models imply neither nitric oxide nor nitrogen dioxide participate extensively in hydrogen atom abstraction reactions. 
Representative products of the hydrogen atom abstraction reactions of glycolate, citrate, EDTA, and glycinate ions are shown in Table 3-5.

3.3.2.2 Initiation by Electron Transfer. The electron transfer initiation reactions of the glycinate ion provide the neutral zwitterion:

$$
\mathrm{A}+\mathrm{H}_{2} \mathrm{NCH}_{2} \mathrm{CO}_{2}^{-} \rightarrow \mathrm{A}^{-}+\mathrm{H}_{2} \mathrm{~N}^{+} \mathrm{CH}_{2} \mathrm{CO}_{2}^{-}
$$

Table 3-5. The Radicals Produced from Glycolate, Citrate, Ethylenediaminetetraacetate, and Glycinate Ions by Hydrogen Atom Abstraction.

\begin{tabular}{|c|c|}
\hline Complexant & Radical \\
\hline Glycolate & $\mathrm{HOCHCO}_{2}{ }^{-}$ \\
\hline Citrate & $\mathrm{HOC}\left(\mathrm{CH}_{2} \mathrm{CO}_{2}\right)\left(\mathrm{CO}_{2}{ }^{-}\right)\left(\mathrm{CHCO}_{2}{ }^{-}\right)$ \\
\hline EDTA & $\left(\mathrm{CO}_{2} \mathrm{CCH}_{2}\right)_{2} \mathrm{NCH}_{2} \mathrm{CH}_{2} \mathrm{~N}_{\left(\mathrm{CH}_{2} \mathrm{CO}_{2}{ }^{-}\right)\left(\mathrm{CHCO}_{2}{ }^{-}\right)}$ \\
& $\left(\mathrm{O}_{2} \mathrm{CCH}_{2}\right)_{2} \mathrm{NCH}_{2} \mathrm{CHN}_{\left(\mathrm{CH}_{2} \mathrm{CO}_{2}\right)_{2}}$ \\
\hline \multirow{2}{*}{ Glycinate } & $\mathrm{H}_{2} \mathrm{NCHCO}_{2}{ }^{-}$ \\
& $\mathrm{HNCH}_{2} \mathrm{CO}_{2}^{-}$ \\
\hline
\end{tabular}

EDTA $=$ ethylenediaminetetraacetate.

The reagent, "A," represents the same family of available free radical reagents discussed in Section 3.3.2.1. The corresponding products, " $\mathrm{A}$;", are the hydride ion, hydroxide ion, oxide ion, nitroxyl anion, nitrite ion, and so forth. Few rate constants for the relevant electron transfer reactions have been measured, but elementary considerations of the thermodynamic requirements for electron transfer from many of these substances eliminate their serious consideration. For example, neither the transfer of the electron from the hydrogen atom to form the hydride ion nor from a carbon-centered radical to form a carbanion is thermodynamically reasonable. In contrast, experimental work with the glycinate ion and EDTA strongly infers that the hydroxyl radical and nitrogen dioxide react by electron transfer to provide pairs containing the zwitterion and the hydroxide ion and nitrite ion, respectively (Bonifacic' et al. 1998; Hobel and von Sonntag 1998; Camaioni et al. 1998).

The zwitterionic intermediate may decompose in a unimolecular process to form a primary radical and liberate carbon dioxide or produce two ionic intermediates:

$$
\begin{gathered}
\mathrm{H}_{2} \mathrm{~N}^{+} \mathrm{CH}_{2} \mathrm{CO}_{2}^{-} \rightarrow \mathrm{H}_{2} \mathrm{NCH}_{2}+\mathrm{CO}_{2} \\
\mathrm{H}_{2} \mathrm{~N}^{+} \mathrm{CH}_{2} \mathrm{CO}_{2}^{-} \rightarrow \mathrm{H}_{2} \mathrm{~N}^{+}=\mathrm{CH}_{2}+\mathrm{CO}_{2}^{-}
\end{gathered}
$$

The reaction leading to the aminomethyl radical and carbon dioxide is thermodynamically much more favorable than the reaction leading to the ionic products. The rate constants for the decomposition of the zwitterion of glycinate is greater than $10^{8} \mathrm{~s}^{-1}$ (Bonifacic' et al. 1998). Values greater than $10^{6} \mathrm{~s}^{-1}$ have been reported for the decomposition of other amino acids 


\section{RPP-6664 REV 0}

(Su et al. 1997). The decarboxylation channel is therefore an important process, particularly for the nitrogen-containing complexants in the waste, leading to a family of primary free radicals.

The primary radicals formed through the electron transfer and decarboxylation are shown in Table 3-6.

Table 3-6. The Radicals Produced from Glycolate, Citrate, Ethylenediaminetetraacetate, and Glycinate Ions by Electron Transfer and Decarboxylation.

\begin{tabular}{|c|c|}
\hline Complexant & Radical \\
\hline Glycolate & $\mathrm{HOCH}_{2}$ \\
\hline Citrate & $\mathrm{HOC}\left(\mathrm{CH}_{2} \mathrm{CO}_{2}{ }^{-}\right)\left(\mathrm{CO}_{2}{ }^{-}\right) \mathrm{CH}_{2}$ \\
\hline EDTA & $\left(\mathrm{O}_{2} \mathrm{CH}_{2}\right)_{2} \mathrm{NCH}_{2} \mathrm{CH}_{2} \mathrm{~N}_{\left(\mathrm{CH}_{2} \mathrm{CO}_{2}{ }^{-}\right)}$ \\
\hline Glycinate & $\mathrm{NH}_{2} \mathrm{CH}_{2}$ \\
\hline
\end{tabular}

EDTA $=$ Ethylenediaminetetraacetate.

A second reaction channel is available to the zwitterion ion. As shown in Figure 3-6, the electron transfer reaction produces an anion radical pair consisting of the basic hydroxide ion and the acidic zwitterion. Proton transfer from carbon and nitrogen can occur to provide the carbon-centered and nitrogen-centered radicals:

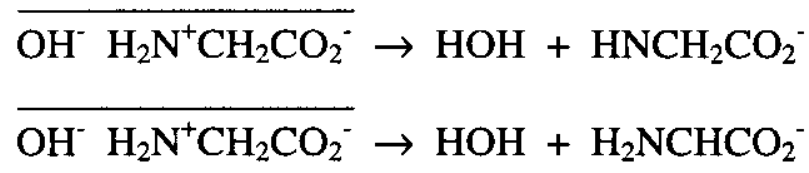

Experimental work with glycinate ion strongly suggests the nitrogen-centered radical is formed preferentially even though it is the thermodynamically less stable radical.

Nitrogen-centered radicals cannot be produced in this manner from the EDTA zwitterion or the other tertiary amines, for example HEDTA and NTA. The acid-base reactions of these substances lead exclusively to the formation of carbon-centered radicals as illustrated by the reaction of EDTA:

$$
\begin{gathered}
\overline{\mathrm{OH}^{-}\left(\mathrm{O}_{2} \mathrm{CH}_{2}\right)_{2} \mathrm{NCH}_{2} \mathrm{CH}_{2} \mathrm{~N}^{+}\left(\mathrm{CH}_{2} \mathrm{CO}_{2}^{-}\right)_{2}} \rightarrow\left(\mathrm{O}_{2} \mathrm{CH}_{2}\right)_{2} \mathrm{NCH}_{2} \mathrm{CHN}\left(\mathrm{CH}_{2} \mathrm{CO}_{2}^{-}\right)_{2} \\
+\left(\mathrm{O}_{2} \mathrm{CH}_{2}\right)_{2} \mathrm{NCH}_{2} \mathrm{CHN}\left(\mathrm{CH}_{2} \mathrm{CO}_{2}^{-}\right)\left(\mathrm{CHCO}_{2}^{-}\right)+\mathrm{HOH}
\end{gathered}
$$

In conclusion, it is notable that the high alkalinity of the waste provides a reaction medium enabling the formation of carbon-centered and nitrogen-centered free radicals from the complexants containing nitrogen atoms by quite indirect electron transfer routes involving radicals that may otherwise be incapable of hydrogen atom abstraction reactions.

3.3.2.3 Propagation Reactions. The radical intermediates formed from the complexants either by hydrogen atom abstraction, electron transfer, or decarboxylation combine with the array of radicals and certain ions in the reaction medium. The principal reactions occur with nitric oxide and nitrogen dioxide, possibly hydroxyl radicals, as well as with the highly abundant nitrite ion, 


\section{RPP-6664 REV 0}

to form new covalent bonds. The bimolecular radical reactions of the glycolate radical are shown to illustrate this chemistry:

$$
\begin{aligned}
\mathrm{HOCHCO}_{2}^{-}+\mathrm{NO} & \rightarrow \mathrm{HOCH}(\mathrm{NO}) \mathrm{CO}_{2}^{-} \\
\mathrm{HOCHCO}_{2}^{-}+\mathrm{NO}_{2} & \rightarrow \mathrm{HOCH}\left(\mathrm{NO}_{2}\right) \mathrm{CO}_{2}^{-} \\
\mathrm{HOCHCO}_{2}^{-}+\mathrm{NO}_{2} & \rightarrow \mathrm{HOCH}(\mathrm{ONO}) \mathrm{CO}_{2}^{-} \\
\mathrm{HOCHCO}_{2}^{-}+\mathrm{OH} & \rightarrow \mathrm{HOCH}(\mathrm{OH}) \mathrm{CO}_{2}^{-}
\end{aligned}
$$

The reactions with nitrous oxide and nitrogen dioxide are favored by the relatively high concentrations of these substances in the waste even though the rate constants for the reactions are rather small. In contrast, the reactions between the organic free radicals and the hydroxyl radical are disfavored because the concentrations of both substances are very small.

The organic radicals presumably also react with nitrite ion (Leffler 1993). This process is favored by the very high concentration of nitrite ion in the waste:

$$
\mathrm{HOCHCO}_{2}{ }^{-}+\mathrm{NO}_{2}{ }^{-} \rightarrow \mathrm{HOCH}\left(\mathrm{NO}_{2}{ }^{-}\right) \mathrm{CO}_{2}{ }^{-}
$$

Electron transfer to one of the numerous acceptor molecules, "A," provides the same product as reaction between the free radical and nitrogen dioxide:

$$
\mathrm{A}+\mathrm{HOCH}\left(\mathrm{NO}_{2}{ }^{-}\right) \mathrm{CO}_{2}{ }^{-} \rightarrow \mathrm{A}^{-}+\mathrm{HOCH}\left(\mathrm{NO}_{2}\right) \mathrm{CO}_{2}^{-}
$$

Consequently, each radical shown in Tables 3-5 and 3-6 can produce these four compounds leading to a very large array of products. The products from glycolate, citrate, EDTA, and glycinate ion are summarized in Table 3-7.

Table 3-7. Intermediate Products of the Recombination Reactions of Radicals Derived from Glycolate, Citrate, Ethylenediaminetetraacetate, and Glycinate Ions. (2 sheets)

\begin{tabular}{|ll|}
\hline \multicolumn{2}{|c|}{ Trom Glycolate } \\
\hline $\mathrm{HOCH}(\mathrm{OH}) \mathrm{CO}_{2}^{-}$ & $\mathrm{HOCH}_{2} \mathrm{OH}$ \\
\hline $\mathrm{HOCH}(\mathrm{ONO}) \mathrm{CO}_{2}^{-}$ & $\mathrm{HOCH}_{2} \mathrm{ONO}$ \\
\hline $\mathrm{HOCH}\left(\mathrm{NO}_{2}\right) \mathrm{CO}_{2}^{-}$ & $\mathrm{HOCH}_{2} \mathrm{NO}_{2}$ \\
\hline $\mathrm{HOCH}(\mathrm{NO}) \mathrm{CO}_{2}^{-}$ & $\mathrm{HOCH}_{2} \mathrm{NO}$ \\
\hline
\end{tabular}

\begin{tabular}{|ll|}
\hline \multicolumn{3}{|c|}{ From Citrate } \\
\hline $\mathrm{HOC}\left(\mathrm{CH}_{2} \mathrm{CO}_{2}^{-}\right)\left(\mathrm{CO}_{2}^{-}\right)\left(\mathrm{CH}(\mathrm{OH}) \mathrm{CO}_{2}^{-}\right)$ & $\mathrm{HOC}\left(\mathrm{CH}_{2} \mathrm{CO}_{2}^{-}\right)\left(\mathrm{CO}_{2}^{-}\right)\left(\mathrm{CH}_{2} \mathrm{OH}\right)$ \\
\hline $\mathrm{HOC}\left(\mathrm{CH}_{2} \mathrm{CO}_{2}^{-}\right)\left(\mathrm{CO}_{2}^{-}\right)\left(\mathrm{CH}(\mathrm{ONO}) \mathrm{CO}_{2}^{-}\right)$ & $\mathrm{HOC}\left(\mathrm{CH}_{2} \mathrm{CO}_{2}^{-}\right)\left(\mathrm{CO}_{2}^{-}\right)\left(\mathrm{CH}_{2} \mathrm{ONO}\right)$ \\
\hline $\mathrm{HOC}\left(\mathrm{CH}_{2} \mathrm{CO}_{2}^{-}\right)\left(\mathrm{CO}_{2}^{-}\right)\left(\mathrm{CH}\left(\mathrm{NO}_{2}\right) \mathrm{CO}_{2}^{-}\right)$ & $\mathrm{HOC}\left(\mathrm{CH}_{2} \mathrm{CO}_{2}^{-}\right)\left(\mathrm{CO}_{2}^{-}\right)\left(\mathrm{CH}_{2} \mathrm{NO}_{2}\right)$ \\
\hline $\mathrm{HOC}\left(\mathrm{CH}_{2} \mathrm{CO}_{2}{ }^{-}\right)\left(\mathrm{CO}_{2}^{-}\right)\left(\mathrm{CH}(\mathrm{NO}) \mathrm{CO}_{2}^{-}\right)$ & $\mathrm{HOC}\left(\mathrm{CH}_{2} \mathrm{CO}_{2}{ }^{-}\right)\left(\mathrm{CO}_{2}^{-}\right)\left(\mathrm{CH}_{2} \mathrm{NO}\right)$ \\
\hline
\end{tabular}

\begin{tabular}{|c|}
\hline From Glycinate \\
\hline $\mathrm{H}_{2} \mathrm{NCH}(\mathrm{OH}) \mathrm{CO}_{2}^{-}$ \\
\hline $\mathrm{H}_{2} \mathrm{NCH}(\mathrm{ONO}) \mathrm{CO}_{2}^{-}$ \\
\hline $\mathrm{H}_{2} \mathrm{NCH}\left(\mathrm{NO}_{2}\right) \mathrm{CO}_{2}^{-}$ \\
\hline $\mathrm{H}_{2} \mathrm{NCH}\left(\mathrm{NO}^{-} \mathrm{CO}_{2}^{-}\right.$ \\
\hline
\end{tabular}

\begin{tabular}{|c|}
\hline \\
\hline$\left(\mathrm{O}_{2} \mathrm{CCH}_{2}\right)_{2} \mathrm{NCH}_{2} \mathrm{CH}_{2} \mathrm{~N}\left(\mathrm{CH}_{2} \mathrm{CO}_{2}\right)\left(\mathrm{CH}(\mathrm{OH}) \mathrm{CO}_{2}{ }^{-}\right)$ \\
\hline$\left(\mathrm{O}_{2} \mathrm{CCH}_{2} \mathrm{NCH}_{2} \mathrm{CH}_{2} \mathrm{~N}_{2}\left(\mathrm{CH}_{2} \mathrm{CO}_{2}\right)\left(\mathrm{CH}(\mathrm{NO}) \mathrm{CO}_{2}{ }^{-}\right)\right.$ \\
\hline$\left(\mathrm{O}_{2} \mathrm{CCH}_{2}\right)_{2} \mathrm{NCH}_{2} \mathrm{CH}_{2} \mathrm{~N}\left(\mathrm{CH}_{2} \mathrm{CO}_{2}\right)\left(\mathrm{CH}\left(\mathrm{NO}_{2}\right) \mathrm{CO}_{2}\right)$ \\
\hline$\left(\mathrm{O}_{2} \mathrm{CCH}_{2}\right)_{2} \mathrm{NCH}_{2} \mathrm{CH}_{2} \mathrm{~N}\left(\mathrm{CH}_{2} \mathrm{CO}_{2}\right)\left(\mathrm{CH}(\mathrm{NO}) \mathrm{CO}_{2}\right)$ \\
\hline
\end{tabular}

\begin{tabular}{|c|}
\hline $\mathrm{HONHCH}$ \\
\hline $\mathrm{CO}_{2}^{-}$ \\
\hline $\mathrm{ONONHCH}_{2} \mathrm{CO}_{2}^{-}$ \\
\hline $\mathrm{O}_{2} \mathrm{NNNHCH}_{2} \mathrm{CO}_{2}$ \\
\hline $\mathrm{ONNHCH}_{2} \mathrm{CO}_{2}$ \\
\hline
\end{tabular}

\begin{tabular}{|c|}
\hline$\left(\mathrm{O}_{2} \mathrm{CCH}_{2}\right)_{2} \mathrm{NCH}_{2} \mathrm{CH}(\mathrm{OH}) \mathrm{N}\left(\mathrm{CH}_{2} \mathrm{CO}_{2}\right)_{2}$ \\
\hline$\left.\left(\mathrm{O}_{2} \mathrm{CCH}_{2}\right)_{2} \mathrm{NCH}_{2} \mathrm{CH}(\mathrm{ONO}) \mathrm{N}_{(2} \mathrm{CH}_{2} \mathrm{CO}_{2}^{-}\right)_{2}$ \\
\hline$\left.\left(\mathrm{O}_{2} \mathrm{CCH}_{2}\right)_{2} \mathrm{NCH}_{2} \mathrm{CH}\left(\mathrm{NO}_{2}\right) \mathrm{N}_{2} \mathrm{CH}_{2} \mathrm{CO}_{2}\right)_{2}$ \\
\hline$\left(\mathrm{O}_{2} \mathrm{CCH}_{2}\right)_{2} \mathrm{NCH}_{2} \mathrm{CH}(\mathrm{NO}) \mathrm{N}\left(\mathrm{CH}_{2} \mathrm{CO}_{2}\right)_{2}$ \\
\hline
\end{tabular}


Table 3-7. Intermediate Products of the Recombination Reactions of Radicals Derived from Glycolate, Citrate, Ethylenediaminetetraacetate, and Glycinate Ions. (2 sheets)

\begin{tabular}{|c|c|}
\hline $\mathrm{H}_{2} \mathrm{NCHOH}$ & $\left(\mathrm{O}_{2} \mathrm{CCH}_{2}\right)_{2} \mathrm{NCH}_{2} \mathrm{CH}_{2} \mathrm{~N}\left(\mathrm{CH}_{2} \mathrm{CO}_{2}\right)\left(\mathrm{CH}_{2} \mathrm{OH}\right)$ \\
\hline $\mathrm{H}_{2} \mathrm{NCHONO}$ & $\left(\mathrm{O}_{2} \mathrm{CCH}_{2}\right)_{2} \mathrm{NCH}_{2} \mathrm{CH}_{2} \mathrm{~N}_{\left(\mathrm{CH}_{2} \mathrm{CO}_{2}{ }^{-}\right)\left(\mathrm{CH}_{2} \mathrm{ONO}\right)}$ \\
\hline $\mathrm{H}_{2} \mathrm{NCHNO}_{2}$ & $\left(\mathrm{O}_{2} \mathrm{CCH}_{2}\right)_{2} \mathrm{NCH}_{2} \mathrm{CH}_{2} \mathrm{~N}_{\left(\mathrm{CH}_{2} \mathrm{CO}_{2}{ }^{-}\right)\left(\mathrm{CH}_{2} \mathrm{NO}_{2}\right)}$ \\
\hline $\mathrm{H}_{2} \mathrm{NCHNO}$ & $\left(\mathrm{O}_{2} \mathrm{CCH}_{2}\right)_{2} \mathrm{NCH}_{2} \mathrm{CH}_{2} \mathrm{~N}_{\left(\mathrm{CH}_{2} \mathrm{CO}_{2}{ }^{-}\right)\left(\mathrm{CH}_{2} \mathrm{NO}\right)}$ \\
\hline
\end{tabular}

EDTA $=$ ethylenediaminetetraacetate.

\subsubsection{Radical Reactions of the Hydrocarbons}

3.3.3.1 Initiation Reactions. The radiolytic reactions of the water-insoluble hydrocarbons take place in the organic layers and micelles. The radiolysis of the hydrocarbons began during the PUREX process and has continued during interim storage. Specific transformations occurring during the PUREX process have been discussed by Davis (1984), and the chemical transformations of hydrocarbons during radiolysis have been discussed by Gyorgy (1981), Spinks and Woods (1990), Tabata et al. (1991), and Bugaenko et al. (1993). Targeted studies have not been carried out because the information in the literature is quite complete.

Hydrocarbon radiolysis begins with the formation of electronically excited molecules and ions (Spinks and Woods 1990; Bugaenko et al. 1993). The formation of an excited state of dodecane and an excited radical cation of dodecane is shown in the first equation to illustrate the process.

$$
\mathrm{C}_{12} \mathrm{H}_{26}+\text { radiation } \rightarrow\left[\mathrm{C}_{12} \mathrm{H}_{26}\right]^{*}+\left[\mathrm{C}_{12} \mathrm{H}_{26}{ }^{+}\right]^{*}
$$

The electronically excited molecules and ions undergo carbon-carbon and carbon-hydrogen bond scission as illustrated for one of the many possible reaction channels (Spinks and Woods 1990) in the next equation:

$$
\left[\mathrm{C}_{12} \mathrm{H}_{26}{ }^{+}\right]^{*} \rightarrow \mathrm{H}^{+}+\text {alkyl radicals }
$$

The original NPH mixtures contained high concentrations of undecane, dodecane, tridecane, and tetradecane with smaller amounts of many different methyl derivatives, for example 2-, 3-, 4-, 5and 6-methyldodecane, and alkyl cyclopentanes, cyclohexanes, and decalins in the same boiling range. The radiolysis of this family of hydrocarbons provides a very broad family of alkyl radicals since each hydrocarbon can be converted to several free radicals. The six radicals obtained from dodecane are shown:

$\mathrm{CH}_{3}\left(\mathrm{CH}_{2}\right)_{5} \mathrm{CH}_{2} \mathrm{CH}_{2} \mathrm{CH}_{2} \mathrm{CH}_{2} \mathrm{CH}_{2} \mathrm{CH}_{2}$

$\mathrm{CH}_{3}\left(\mathrm{CH}_{2}\right)_{5} \mathrm{CH}_{2} \mathrm{CH}_{2} \mathrm{CH}_{2} \mathrm{CH}_{2} \mathrm{CHCH}_{3}$

$\mathrm{CH}_{3}\left(\mathrm{CH}_{2}\right)_{5} \mathrm{CH}_{2} \mathrm{CH}_{2} \mathrm{CH}_{2} \mathrm{CHCH}_{2} \mathrm{CH}_{3}$

$\mathrm{CH}_{3}\left(\mathrm{CH}_{2}\right)_{5} \mathrm{CH}_{2} \mathrm{CH}_{2} \mathrm{CHCH}_{2} \mathrm{CH}_{2} \mathrm{CH}_{3}$

$\mathrm{CH}_{3}\left(\mathrm{CH}_{2}\right)_{5} \mathrm{CH}_{2} \mathrm{CHCH}_{2} \mathrm{CH}_{2} \mathrm{CH}_{2} \mathrm{CH}_{3}$

$\mathrm{CH}_{3}\left(\mathrm{CH}_{2}\right)_{5} \mathrm{CHCH}_{2} \mathrm{CH}_{2} \mathrm{CH}_{2} \mathrm{CH}_{2} \mathrm{CH}_{3}$ 


\section{RPP-6664 REV 0}

The same radicals are produced when the excited molecules decompose by the loss of a hydrogen atom or an alkyl radical. The radiolysis of a complex mixture of hydrocarbons produces a complex mixture of alkyl radicals. The same large group of alkyl radicals is formed by the reactions of the hydrocarbons with the hydrogen atoms and hydroxyl radicals formed through the radiolysis of water.

3.3.3.2 Propagation Reactions. Alkyl radicals decompose by beta scission (Leffler 1993) to form an alkene and a hydrogen atom as illustrated for the 2-dodecanyl radical:

$$
\mathrm{CH}_{3}\left(\mathrm{CH}_{2}\right)_{6} \mathrm{CH}_{2} \mathrm{CH}_{2} \mathrm{CH}_{2} \mathrm{CHCH}_{3} \rightarrow \mathrm{H}+\mathrm{CH}_{3}\left(\mathrm{CH}_{2}\right)_{6} \mathrm{CH}_{2} \mathrm{CH}_{2} \mathrm{CH}_{2} \mathrm{CH}=\mathrm{CH}_{2}
$$

They may also form an alkyl free radical and an alkene as illustrated for the reactions of the 2- and 3-dodecanyl radicals:

$$
\begin{gathered}
\mathrm{CH}_{3}\left(\mathrm{CH}_{2}\right)_{6} \mathrm{CH}_{2} \mathrm{CH}_{2} \mathrm{CH}_{2} \mathrm{CHCH}_{3} \rightarrow \mathrm{CH}_{3}\left(\mathrm{CH}_{2}\right)_{6} \mathrm{CH}_{2} \mathrm{CH}_{2}+\mathrm{CH}_{2}=\mathrm{CHCH}_{3} \\
\mathrm{CH}_{3}\left(\mathrm{CH}_{2}\right)_{6} \mathrm{CH}_{2} \mathrm{CH}_{2} \mathrm{CHCH}_{2} \mathrm{CH}_{3} \rightarrow \mathrm{CH}_{3}\left(\mathrm{CH}_{2}\right)_{6} \mathrm{CH}_{2}+\mathrm{CH}_{2}=\mathrm{CHCH}_{2} \mathrm{CH}_{3} \\
\mathrm{CH}_{3}\left(\mathrm{CH}_{2}\right)_{6} \mathrm{CH}_{2} \mathrm{CH}_{2} \mathrm{CHCH}_{2} \mathrm{CH}_{3} \rightarrow \mathrm{CH}_{3}\left(\mathrm{CH}_{2}\right)_{8} \mathrm{CH}=\mathrm{CH}_{2}+\mathrm{CH}_{3}
\end{gathered}
$$

The products obtained from dodecane through these reactions include the entire homologous series of linear radicals beginning with methyl radical and extending to the 1-undecanyl radical and the entire family of alkenes, beginning with ethene and extending to 1-dodecene.

The alkyl radicals also abstract hydrogen atoms from other alkanes. The reactions of the alkyl radicals noted in the previous paragraph (i.e., methyl, ethyl, propyl, butyl, pentyl, hexyl, and so forth) produce the corresponding alkanes methane, ethane, propane, butane, pentane, hexane, and so forth to give a homologous series of alkanes.

Radical reactions generally occur without structural rearrangement, and the original normal hydrocarbons of the NPH yield homologous series of normal radicals, alkanes, and alkenes. The beta scission reactions lead to products in which the original NPH molecule is fragmented into lower molecular weight alkanes and alkenes.

Radiolysis of the waste also yields transient radicals, including the hydroxyl radical, nitric oxide, and nitrogen dioxide. As already discussed in Section 3.3.2.3, these substances combine with radicals to produce other families of oxidized intermediate compounds. The homologous series of alkyl radicals, represented by " $\mathrm{RCH}_{2}$," produce $\mathrm{C}$-nitroso and $\mathrm{C}$-nitro compounds and a homologous series of alcohols and nitrite esters:

$$
\begin{aligned}
\mathrm{RCH}_{2}+\mathrm{OH} & \rightarrow \mathrm{RCH}_{2} \mathrm{OH} \\
\mathrm{RCH}_{2}+\mathrm{NO}_{2} & \rightarrow \mathrm{RCH}_{2} \mathrm{ONO} \\
\mathrm{RCH}_{2}+\mathrm{NO} & \rightarrow \mathrm{RCH}_{2} \mathrm{NO} \\
\mathrm{RCH}_{2}+\mathrm{NO}_{2} & \rightarrow \mathrm{RCH}_{2} \mathrm{NO}_{2}
\end{aligned}
$$

The reactions with nitric oxide and nitrogen dioxide predominate because the concentration of hydroxyl radical is very low (Camaioni and Autrey 2000). 


\section{RPP-6664 REV 0}

In summary, the families of alkyl radicals form families of alcohols, nitrite esters, and nitro compounds, many of which occur in homologous series. The net result is that the original NPHs are fragmented into lower molecular weight alkanes and oxidized. As these reactions proceed, the molecular dimensions are reduced and the reaction products are more water soluble and more volatile than the original hydrocarbons.

\subsubsection{Radical Reactions of the Phosphate Esters}

3.3.4.1 Initiation Reactions. As indicated in Section 3.2.2, the radiolysis of TBP has been extensively investigated (Davis 1984). Camaioni et al. investigated the radiolysis of sodium DBP in alkaline solution (Camaioni et al. 1996a). Their observations, which are illustrated in Figure 3-4, and other work in the literature (Davis 1984) indicate that the butyl groups of the phosphate esters are oxidized to produce new families of dialkyl and monoalkyl phosphates together with other organic compounds derived from the fragmentation of the butyl groups. Targeted investigations of the radiolysis of sodium bis(2-ethylhexyl)phosphate have not been carried out. But it is evident from the persistence of the molecule in the waste that the radiolysis proceeds very slowly, presumably because the sodium bis(2-ethylhexyl)phosphate is so insoluble in water (Stauffer and Stock 1999).

The radiolytic reactions of the phosphate esters that lead to oxidized intermediate phosphate esters and fragmented molecules can be formulated in exactly the same way as the reactions of the complexants and hydrocarbons (Davis 1984). The direct radiolytic reactions proceed through excited molecules and ions. In addition, other radical reactions are initiated by electron transfer and by hydrogen atom abstraction reactions.

The electronically excited cation radical formed from TBP and the related neutral radical formed from bis(2-ethylhexyl)phosphate anion provide direct pathways to important products:

$$
\begin{aligned}
& \left.\left(\mathrm{CH}_{3} \mathrm{CH}_{2} \mathrm{CH}_{2} \mathrm{CH}_{2} \mathrm{O}\right)_{3} \mathrm{P}(=\mathrm{O}) \rightarrow\left(\mathrm{CH}_{3} \mathrm{CH}_{2} \mathrm{CH}_{2} \mathrm{CH}_{2} \mathrm{O}\right)_{3} \mathrm{P}(=\mathrm{O})\right]^{+} \\
& \left(\mathrm{CH}_{3}\left(\mathrm{CH}_{2}\right)_{3} \mathrm{CH}\left(\mathrm{CH}_{2} \mathrm{CH}_{3}\right) \mathrm{CH}_{2} \mathrm{O}\right)_{2} \mathrm{P}(=\mathrm{O}) \mathrm{O}^{-} \rightarrow\left(\mathrm{CH}_{3}\left(\mathrm{CH}_{2}\right)_{3} \mathrm{CH}\left(\mathrm{CH}_{2} \mathrm{CH}_{3}\right) \mathrm{CH}_{2} \mathrm{O}\right)_{2} \mathrm{P}(=\mathrm{O}) \mathrm{O}
\end{aligned}
$$

These substances have a diverse chemistry, and only two reaction channels will be outlined here. Proton loss from the excited cation radical of TBP provides four radicals.

$$
\begin{aligned}
& \left.\left(\mathrm{C}_{4} \mathrm{H}_{9} \mathrm{O}\right)_{3} \mathrm{P}(=\mathrm{O})\right]^{+} \rightarrow \mathrm{H}^{+}+\left(\mathrm{CH}_{3} \mathrm{CH}_{2} \mathrm{CH}_{2} \mathrm{CH}_{2} \mathrm{O}\right)_{2}\left(\mathrm{CH}_{3} \mathrm{CH}_{2} \mathrm{CH}_{2} \mathrm{CHO}\right) \mathrm{P}(=\mathrm{O}) \\
& \left.\left(\mathrm{C}_{4} \mathrm{H}_{9} \mathrm{O}\right)_{3} \mathrm{P}(=\mathrm{O})\right]^{+} \rightarrow \mathrm{H}^{+}+\left(\mathrm{CH}_{3} \mathrm{CH}_{2} \mathrm{CH}_{2} \mathrm{CH}_{2} \mathrm{O}\right)_{2}\left(\mathrm{CH}_{3} \mathrm{CH}_{2} \mathrm{CHCH}_{2} \mathrm{O}\right) \mathrm{P}(=\mathrm{O}) \\
& \left.\left(\mathrm{C}_{4} \mathrm{H}_{9} \mathrm{O}\right)_{3} \mathrm{P}(=\mathrm{O})\right]^{+} \rightarrow \mathrm{H}^{+}+\left(\mathrm{CH}_{3} \mathrm{CH}_{2} \mathrm{CH}_{2} \mathrm{CH}_{2} \mathrm{O}\right)_{2}\left(\mathrm{CH}_{3} \mathrm{CHCH}_{2} \mathrm{CH}_{2} \mathrm{O}\right) \mathrm{P}(=\mathrm{O}) \\
& \left.\left(\mathrm{C}_{4} \mathrm{H}_{9} \mathrm{O}\right)_{3} \mathrm{P}(=\mathrm{O})\right]^{+} \rightarrow \mathrm{H}^{+}+\left(\mathrm{CH}_{3} \mathrm{CH}_{2} \mathrm{CH}_{2} \mathrm{CH}_{2} \mathrm{O}\right)_{2}\left(\mathrm{CH}_{2} \mathrm{CH}_{2} \mathrm{CH}_{2} \mathrm{CH}_{2} \mathrm{O}\right) \mathrm{P}(=\mathrm{O})
\end{aligned}
$$

The unimolecular and bimolecular reactions of these substances will be examined in the next section.

Proton loss does not occur with the neutral radical obtained from the bis(2-ethylhexyl)phosphate anion. The nature of the compounds that emerged from tank 241-C-106 during sluicing implies that the principal reaction of the initial radical is beta scission to from the alkoxy radical: 


\section{RPP-6664 REV 0}

\section{$\left(\mathrm{CH}_{3}\left(\mathrm{CH}_{2}\right)_{3} \mathrm{CH}\left(\mathrm{CH}_{2} \mathrm{CH}_{3}\right) \mathrm{CH}_{2} \mathrm{O}\right)_{2} \mathrm{P}(=\mathrm{O}) \mathrm{O} \rightarrow \mathrm{CH}_{3}\left(\mathrm{CH}_{2}\right)_{3} \mathrm{CH}_{2} \mathrm{CH}\left(\mathrm{CH}_{2} \mathrm{CH}_{3}\right) \mathrm{CH}_{2} \mathrm{O}$}

The alkoxy radical decomposes to provide the 3-heptanyl radical and formaldehyde as described in the next section (Stauffer and Stock 1999).

3.3.4.2 Propagation Reactions. The chemistry of the radicals produced by the radiolysis of the phosphate esters follows the same pathways outlined for the complexants and hydrocarbons. The beta scission reactions of the radicals derived from TBP lead to simple alkenes and alkyl radicals and new phosphate esters. Many different compounds can form, as illustrated in the following equations, which show the formation of four new phosphate esters, the methyl radical, and butene from one of the four possible initial radicals:

$$
\begin{gathered}
\left(\mathrm{CH}_{3} \mathrm{CH}_{2} \mathrm{CH}_{2} \mathrm{CH}_{2} \mathrm{O}\right)_{2}\left(\mathrm{CH}_{3} \mathrm{CH}_{2} \mathrm{CHCH}_{2} \mathrm{O}\right) \mathrm{P}(=\mathrm{O}) \rightarrow \\
\left(\mathrm{CH}_{3} \mathrm{CH}_{2} \mathrm{CH}_{2} \mathrm{CH}_{2} \mathrm{O}\right)_{2}\left(\mathrm{CH}_{3} \mathrm{CH}=\mathrm{CHCH}_{2} \mathrm{O}\right) \mathrm{P}(=\mathrm{O}) \\
\left(\mathrm{CH}_{3} \mathrm{CH}_{2} \mathrm{CH}_{2} \mathrm{CH}_{2} \mathrm{O}\right)_{2}\left(\mathrm{CH}_{3} \mathrm{CH}_{2} \mathrm{CH}=\mathrm{CHO}\right) \mathrm{P}(=\mathrm{O}) \\
\left.\mathrm{CH}_{3}+\left(\mathrm{CH}_{3} \mathrm{CH}_{2} \mathrm{CH}_{2} \mathrm{CH}_{2} \mathrm{O}\right)_{2} \mathrm{CH}_{2}=\mathrm{CHCH}_{2} \mathrm{O}\right) \mathrm{P}(=\mathrm{O}) \\
\mathrm{CH}_{3} \mathrm{CH}_{2} \mathrm{CH}=\mathrm{CH}_{2}+\left(\mathrm{CH}_{3} \mathrm{CH}_{2} \mathrm{CH}_{2} \mathrm{CH}_{2} \mathrm{O}\right)_{2} \mathrm{PO}_{2}
\end{gathered}
$$

In addition, alcohols, nitro compounds, and nitrite esters are formed in the reactions of the radicals derived from TBP, with reactive inorganic radicals produced during radiolysis. These intermediate compounds are shown in Table 3-8.

Table 3-8. Intermediate Products of the Reactions of Radicals Derived from Tributyl Phosphate.

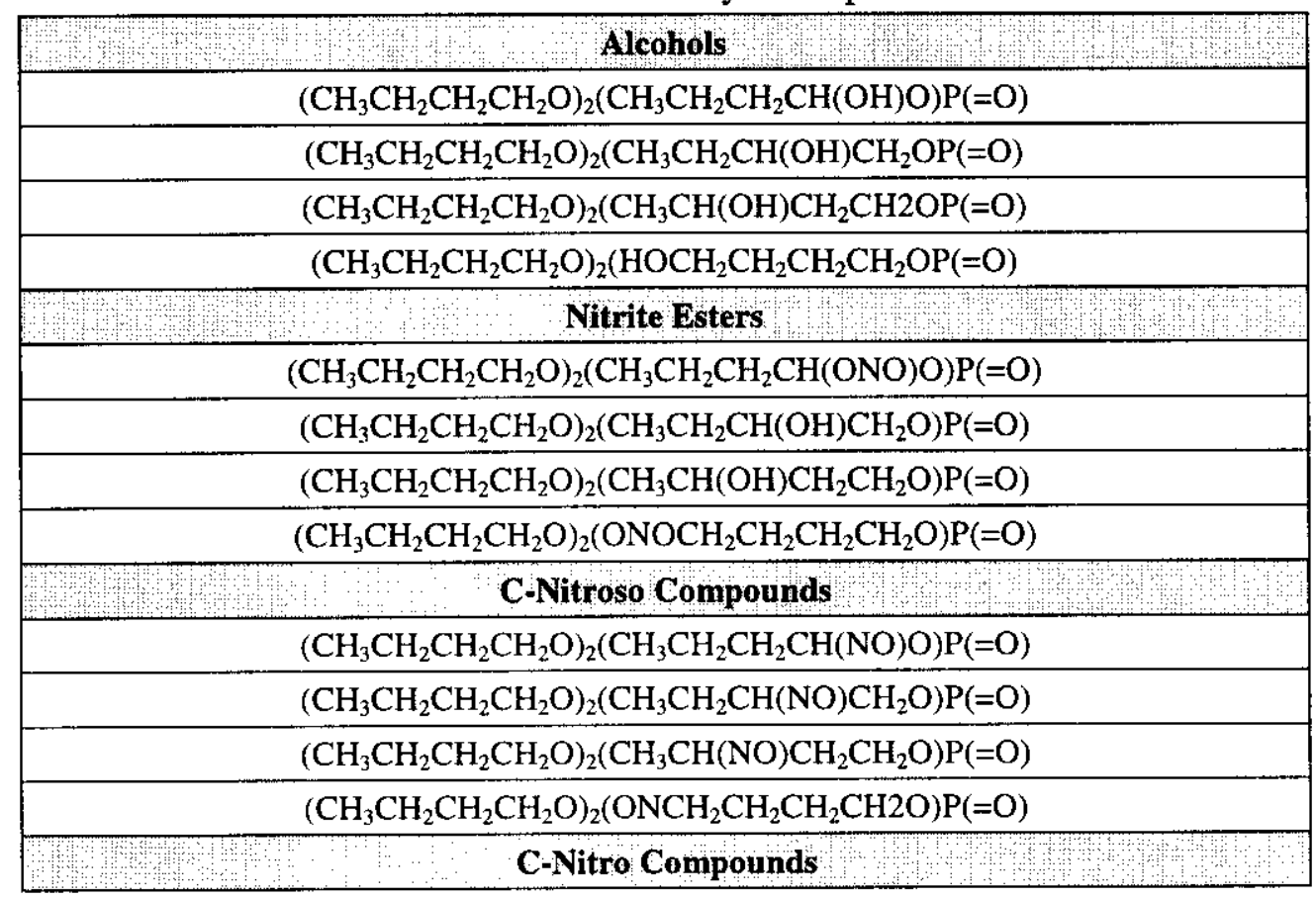




\section{RPP-6664 REV 0}

Table 3-8. Intermediate Products of the Reactions of Radicals Derived from Tributyl Phosphate.

\begin{tabular}{|c|}
\hline$\left(\mathrm{CH}_{3} \mathrm{CH}_{2} \mathrm{CH}_{2} \mathrm{CH}_{2} \mathrm{O}\right)_{2}\left(\mathrm{CH}_{3} \mathrm{CH}_{2} \mathrm{CH}_{2} \mathrm{CH}\left(\mathrm{NO}_{2}\right) \mathrm{OP}(=\mathrm{O})\right.$ \\
\hline$\left(\mathrm{CH}_{3} \mathrm{CH}_{2} \mathrm{CH}_{2} \mathrm{CH}_{2} \mathrm{O}\right)_{2}\left(\mathrm{CH}_{3} \mathrm{CH}_{2} \mathrm{CH}\left(\mathrm{NO}_{2}\right) \mathrm{CH}_{2} \mathrm{OP}(=\mathrm{O})\right.$ \\
\hline$\left(\mathrm{CH}_{3} \mathrm{CH}_{2} \mathrm{CH}_{2} \mathrm{CH}_{2} \mathrm{O}\right)_{2}\left(\mathrm{CH}_{3} \mathrm{CH}\left(\mathrm{NO}_{2}\right) \mathrm{CH}_{2} \mathrm{CH}_{2} \mathrm{O}\right) \mathrm{P}(=\mathrm{O})$ \\
\hline$\left(\mathrm{CH}_{3} \mathrm{CH}_{2} \mathrm{CH}_{2} \mathrm{CH}_{2} \mathrm{O}\right)_{2}\left(\mathrm{O}_{2} \mathrm{NCH}_{2} \mathrm{CH}_{2} \mathrm{CH}_{2} \mathrm{CH}_{2} \mathrm{O}\right) \mathrm{P}(=\mathrm{O})$ \\
\hline
\end{tabular}

The radical derived from the bis(2-ethylhexyl)phosphate anion decomposes through beta scission to yield an alkoxy radical:

$$
\left(\mathrm{CH}_{3} \mathrm{CH}_{2} \mathrm{CH}_{2} \mathrm{CH}_{2} \mathrm{CH}\left(\mathrm{CH}_{2} \mathrm{CH}_{3}\right) \mathrm{CH}_{2} \mathrm{O}\right)_{2} \mathrm{P}(=\mathrm{O}) \mathrm{O} \rightarrow
$$

$$
\mathrm{CH}_{3} \mathrm{CH}_{2} \mathrm{CH}_{2} \mathrm{CH}_{2} \mathrm{CH}\left(\mathrm{CH}_{2} \mathrm{CH}_{3}\right) \mathrm{CH}_{2} \mathrm{O}+\left(\mathrm{CH}_{3} \mathrm{CH}_{2} \mathrm{CH}_{2} \mathrm{CH}_{2} \mathrm{CH}\left(\mathrm{CH}_{2} \mathrm{CH}_{3}\right) \mathrm{CH}_{2} \mathrm{O}\right) \mathrm{PO}_{2}
$$

The alkoxy radical can decompose to 3-heptanyl radical and formaldehyde (Leffler 1993):

$$
\mathrm{CH}_{3} \mathrm{CH}_{2} \mathrm{CH}_{2} \mathrm{CH}_{2} \mathrm{CH}\left(\mathrm{CH}_{2} \mathrm{CH}_{3}\right) \mathrm{CH}_{2} \mathrm{O} \rightarrow \mathrm{CH}_{3} \mathrm{CH}_{2} \mathrm{CH}_{2} \mathrm{CH}_{2} \mathrm{CHCH}_{2} \mathrm{CH}_{3}+\mathrm{CH}_{2} \mathrm{O}
$$

Hydrogen atom loss produces the 3-heptanyl radical, which gives the 2- and 3-heptenes:

$$
\begin{aligned}
& \mathrm{CH}_{3} \mathrm{CH}_{2} \mathrm{CH}_{2} \mathrm{CH}_{2} \mathrm{CHCH}_{2} \mathrm{CH}_{3} \rightarrow \mathrm{H}+\mathrm{CH}_{3} \mathrm{CH}_{2} \mathrm{CH}_{2} \mathrm{CH}_{2} \mathrm{CH}=\mathrm{CHCH}_{3} \\
& \mathrm{CH}_{3} \mathrm{CH}_{2} \mathrm{CH}_{2} \mathrm{CH}_{2} \mathrm{CHCH}_{2} \mathrm{CH}_{3} \rightarrow \mathrm{H}+\mathrm{CH}_{3} \mathrm{CH}_{2} \mathrm{CH}_{2} \mathrm{CH}=\mathrm{CHCH}_{2} \mathrm{CH}_{3}
\end{aligned}
$$

1,4-Hydrogen atom transfer leads to the 2-heptanyl radical(Leffler 1993):

$$
\mathrm{CH}_{3} \mathrm{CH}_{2} \mathrm{CH}_{2} \mathrm{CH}_{2} \mathrm{CHCH}_{2} \mathrm{CH}_{3} \rightarrow \mathrm{CH}_{3} \mathrm{CHCH}_{2} \mathrm{CH}_{2} \mathrm{CH}_{2} \mathrm{CH}_{2} \mathrm{CH}_{3}
$$

The 2-heptanyl radical leads to the 1- and 2-heptenes. Reactions of these intermediate radicals with the inorganic reagents provide the array of products shown in Table 3-9. 
Table 3-9. Intermediate Products of the Reactions of 2- and 3-Heptanyl

Radicals Derived from Sodium bis(2-Ethylhexyl)phosphate.

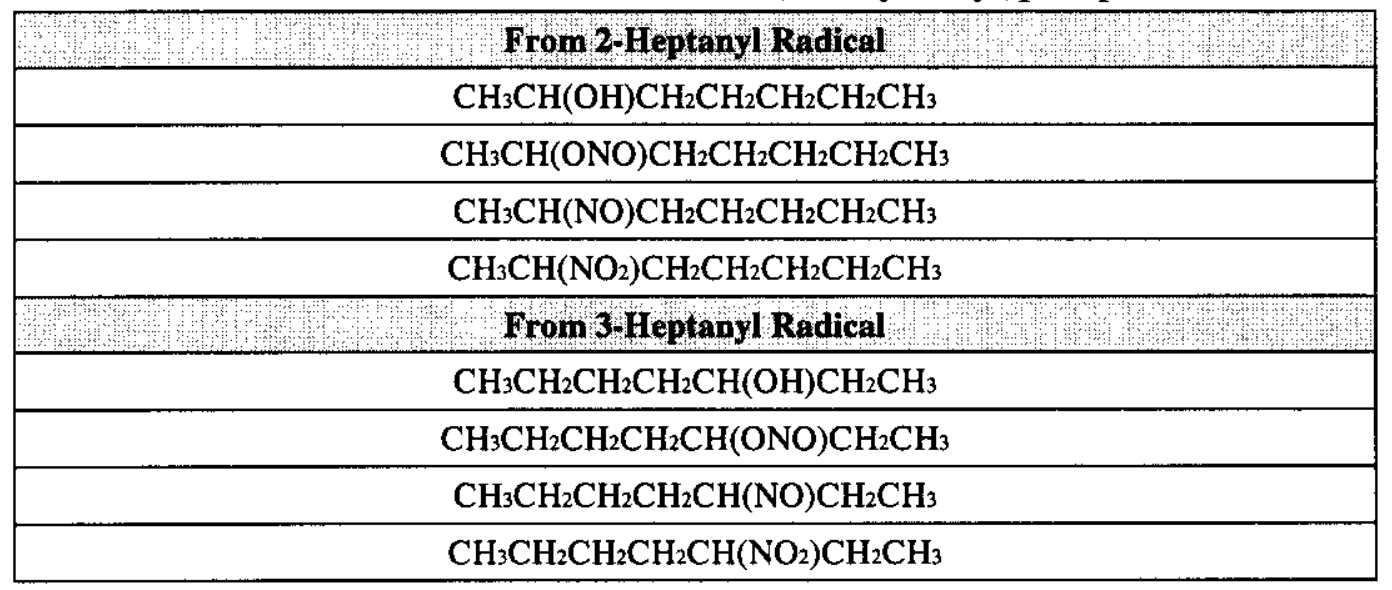

Significant quantities of 1-butanol are formed during the hydrolysis of TBP. Camaioni et al. (1996a) have investigated the radiolysis of this compound. Their work and other work in the literature (Spinks and Woods 1990) imply that the same kinds of intermediates (i.e., alcohols, nitroso and nitro compounds) are produced from this compound.

In summary, the radiolysis of the butyl and 2-ethylhexyl phosphates provide oxidized phosphate esters, 1-butene, the 1-, 2-, and 3-heptenes, and an array of oxidized intermediates. The origins of other reaction products of special interest are discussed by Stauffer and Stock (1999).

\subsubsection{Reaction Pathways of Organic Intermediates}

Other reaction pathways contribute to gas formation and the oxidation of the organic solvents and complexants. The original complexants undergo certain base-catalyzed reactions, and many of the intermediate organic reaction products shown in Tables 3-7, 3-8, and 3-9 react with water and are transformed into other more stable compounds. The intermediates with two electronegative substituents bonded to one tetrahedral carbon atom are converted in reactions with water into new substances in which the hydroxyl, nitro, and nitroso groups are converted to carbonyl or carboxyl groups (Jencks 1969; Lowry and Richardson 1987; Carey and Sundberg 1990; March 1992). These reaction sequences and other ionic conversion reactions are outlined in this section.

3.3.5.1 Reactions of Nitrate and Nitrite Esters and 1,2-Diols. Nitrite esters can be formed by the reactions discussed in Section 3.3.4. However, the reactions responsible for the formation of the nitrate esters that are found in many wastes have not been established by laboratory work. These esters could be produced in reactions between nitrogen trioxide and the organic radicals, through reactions between alkylperoxy radicals and nitrogen dioxide, or through reactions between the alcohols and dinitrogen trioxide and dinitrogen tetraoxide. The latter reaction is discussed here. As shown in the chemical model for radiolysis in Table 3-4, hydroxide ion reacts with dinitrogen trioxide and dinitrogen tetraoxide to form nitrous and nitric acid: 


\section{RPP-6664 REV 0}

$$
\begin{aligned}
\mathrm{HO}^{-}+\mathrm{ONONO} & \rightarrow \mathrm{HONO}+\mathrm{ONO}^{-} \\
\mathrm{HO}^{-}+\mathrm{O}_{2} \mathrm{NONO} & \rightarrow \mathrm{HONO}_{2}+\mathrm{ONO}^{-}
\end{aligned}
$$

Similar reactions with the alkoxide ions, "RO", which are in equilibrium with the alcohols, "ROH," are therefore plausible pathways for the formation of nitrite and nitrate esters. The concept that these substances are formed by the reactions of the alcohols is compatible with the fact that butyl derivatives are especially prevalent. These substances would result from the reactions of 1-butanol, the abundant product of hydrolysis of the butylphosphates:

$$
\begin{aligned}
\mathrm{RCH}_{2} \mathrm{OH}+\mathrm{HO}^{-} & \rightarrow \mathrm{RCH}_{2} \mathrm{O}^{-}+\mathrm{H}_{2} \mathrm{O} \\
\mathrm{RCH}_{2} \mathrm{O}^{-}+\mathrm{ONONO} & \rightarrow \mathrm{RCH}_{2} \mathrm{ONO}+\mathrm{ONO}^{-} \\
\mathrm{RCH}_{2} \mathrm{O}^{-}+\mathrm{O}_{2} \mathrm{NONO} & \rightarrow \mathrm{RCH}_{2} \mathrm{ONO}_{2}+\mathrm{ONO}^{-}
\end{aligned}
$$

The rate constants for the hydrolysis of primary alkyl nitrates and nitrites are approximately $5 \times 10^{-4} \mathrm{~L} \mathrm{~mole}^{-1} \mathrm{~s}^{-1}$ (Oae et al. 1978; Challis and Shuker 1979; Camaioni and Autrey 2000).

$$
\begin{aligned}
& \mathrm{RCH}_{2} \mathrm{ONO}+\mathrm{OH}^{-} \rightarrow \mathrm{RCH}_{2} \mathrm{OH}+\mathrm{NO}_{2}^{-} \\
& \mathrm{RCH}_{2} \mathrm{ONO}_{2}+\mathrm{OH}^{-} \rightarrow \mathrm{RCH}_{2} \mathrm{OH}+\mathrm{NO}_{3}^{-}
\end{aligned}
$$

This formulation suggests the nitrite and nitrate esters are formed and hydrolyzed in a dynamic reaction system under the conditions of interim storage.

Many of the nitrite esters shown in Tables 3-7, 3-8, and 3-9 have an additional hydroxyl group bonded to the same carbon atom. The hydrolytic reactions of these compounds, for example the derivatives of glycolate and glycinate ions, produce other unstable intermediates:

$$
\begin{aligned}
\mathrm{HOCH}(\mathrm{ONO}) \mathrm{CO}_{2}^{-}+\mathrm{OH}^{-} & \rightarrow \mathrm{HOCH}(\mathrm{OH}) \mathrm{CO}_{2}^{-}+\mathrm{NO}_{2}^{-} \\
\mathrm{HOCH}_{2} \mathrm{ONO}+\mathrm{OH}^{-} & \rightarrow \mathrm{HOCH} \mathrm{OH}_{2}+\mathrm{NO}_{2}^{-} \\
\mathrm{H}_{2} \mathrm{NCH}(\mathrm{ONO}) \mathrm{CO}_{2}^{-}+\mathrm{OH}^{-} & \rightarrow \mathrm{H}_{2} \mathrm{NCH}(\mathrm{OH}) \mathrm{CO}_{2}^{-}+\mathrm{NO}_{2}^{-} \\
\mathrm{H}_{2} \mathrm{NCH}_{2} \mathrm{ONO}+\mathrm{OH}^{-} & \rightarrow \mathrm{H}_{2} \mathrm{NCH}_{2} \mathrm{OH}+\mathrm{NO}_{2}^{-}
\end{aligned}
$$

The two nitrite esters provided by glycolate ion are hydrolyzed to diols with both hydroxyl groups on the same carbon atom. The two nitrite esters formed from glycinate yield compounds with an amino group and a hydroxyl group bonded to the same carbon atom as illustrated by the reactions of the two glycinate ions. These compounds undergo hydrolysis to liberate the amine and formaldehyde (Lowry and Richardson 1987; Carey and Sundberg 1990; March 1992). Formaldehyde and glyoxalate ions are obtained from the compounds under discussion.

$$
\begin{aligned}
\mathrm{HOCH}(\mathrm{OH}) \mathrm{CO}_{2}^{-} & \rightarrow \mathrm{OCHCO}_{2}^{-}+\mathrm{H}_{2} \mathrm{O} \\
\mathrm{HOCH} \mathrm{OH}_{2} & \rightarrow \mathrm{CH}_{2} \mathrm{O}+\mathrm{H}_{2} \mathrm{O} \\
\mathrm{H}_{2} \mathrm{NCH}(\mathrm{OH}) \mathrm{CO}_{2}^{-} & \rightarrow \mathrm{OCHCO}_{2}^{-}+\mathrm{NH}_{3} \\
\mathrm{H}_{2} \mathrm{NCH}_{2} \mathrm{OH} & \rightarrow \mathrm{CH}_{2} \mathrm{O}+\mathrm{NH}_{3}
\end{aligned}
$$


The recombination reactions of the primary radicals from HEDTA and EDTA introduce hydroxyl groups directly or indirectly through the nitrite esters. These substances exhibit the same chemistry.

$$
\begin{gathered}
\left(\mathrm{O}_{2} \mathrm{CCH}_{2}\right)_{2} \mathrm{NCH}_{2} \mathrm{CH}_{2} \mathrm{~N}\left(\mathrm{CH}_{2} \mathrm{CO}_{2}^{-}\right)\left(\mathrm{CH}_{2} \mathrm{ONO}\right)+\mathrm{OH}^{-} \rightarrow \\
\left(\mathrm{O}_{2} \mathrm{CCH}_{2}\right)_{2} \mathrm{NCH}_{2} \mathrm{CH}_{2} \mathrm{~N}\left(\mathrm{CH}_{2} \mathrm{CO}_{2}^{-}\right)\left(\mathrm{CH}_{2} \mathrm{OH}\right)+\mathrm{NO}_{2}^{-} \\
\left(\mathrm{O}_{2} \mathrm{CCH}_{2}\right)_{2} \mathrm{NCH}_{2} \mathrm{CH}_{2} \mathrm{~N}\left(\mathrm{CH}_{2} \mathrm{CO}_{2}^{-}\right)\left(\mathrm{CH}_{2} \mathrm{OH}\right) \rightarrow \\
\mathrm{CH}_{2} \mathrm{O}+\left({ }^{-} \mathrm{O}_{2} \mathrm{CCH}_{2}\right)_{2} \mathrm{NCH}_{2} \mathrm{CH}_{2} \mathrm{NH}\left(\mathrm{CH}_{2} \mathrm{CO}_{2}^{-}\right)
\end{gathered}
$$

The illustration shows the conversion of EDTA into ED3A and formaldehyde. Formaldehyde is formed from many different complexants and their remnants.

Another well-known reaction occurs in competition with the simple hydrolysis reaction. At high $\mathrm{pH}$, hydroxide ion abstracts a proton from the primary carbon to provide an aldehyde directly from the nitrite esters (Lowry and Richardson 1987; Carey and Sundberg 1990; March 1992) in a reaction that liberates the nitrosyl anion:

$$
\mathrm{RCH}_{2} \mathrm{ONO}+\mathrm{OH}^{-} \rightarrow \mathrm{RCHO}+\mathrm{NO}^{-}+\mathrm{H}_{2} \mathrm{O}
$$

When there is a second electronegative group on the reactive carbon atom, the reaction of the nitrite ester provides the formate ion:

$$
\mathrm{HOCH}_{2} \mathrm{ONO}+2 \mathrm{OH}^{-} \rightarrow \mathrm{HCO}_{2}^{+}+\mathrm{NO}^{-}+2 \mathrm{H}_{2} \mathrm{O}
$$

3.3.5.2 Ionic Base-Catalyzed Oxidation Reactions of Aldehydes. Hydroxide ion-catalyzed transformations of aldehydes are an important source of hydrogen in Hanford Site wastes. Ashby et al. $(1993,1994)$ and Barefield et al. $(1995,1996)$ have described the importance of this variant of the Cannizzaro reaction (Lowry and Richardson 1987; Carey and Sundberg 1990; March 1992) for the production of hydrogen and sodium formate from formaldehyde:

$$
\begin{gathered}
\mathrm{H}_{2} \mathrm{CO}+\mathrm{OH}^{-} \rightarrow \mathrm{H}_{2} \mathrm{COH}\left(\mathrm{O}^{-}\right)+\mathrm{H}_{2} \mathrm{O} \\
\mathrm{H}_{2} \mathrm{COH}\left(\mathrm{O}^{-}\right)+\mathrm{OH}^{-} \rightarrow \mathrm{H}_{2} \mathrm{C}\left(\mathrm{O}^{-}\right)_{2}+\mathrm{H}_{2} \mathrm{O} \\
\mathrm{H}_{2} \mathrm{C}\left(\mathrm{O}^{-}\right)_{2}+\mathrm{H}_{2} \mathrm{O} \rightarrow \mathrm{HCO}_{2}^{-}+\mathrm{OH}^{-}+\mathrm{H}_{2}
\end{gathered}
$$

Formaldehyde, as discussed in the previous section, is an important product of the fragmentation reactions of the complexants. This substance is readily hydrated in aqueous solution, and the protons of the hydrate are sufficiently acidic to be removed by hydroxide ion to form a dianion. The reaction between this anion and water to form hydrogen and the formate ion is the dominant decomposition pathway for formaldehyde in strongly alkaline solutions (Ashby et al. 1993). 


\section{RPP-6664 REV 0}

The hydrate from glyoxalate ion undergoes the same reactions as formaldehyde and also provides hydrogen. The diol can produce hydrogen directly without forming the aldehyde, as shown in the equations describing the entire reaction sequence:

$$
\begin{aligned}
& \mathrm{HOCHCO}_{2}{ }^{-}+\mathrm{NO}_{2} \rightarrow \mathrm{HOCH}(\mathrm{ONO}) \mathrm{CO}_{2}{ }^{-} \\
& \mathrm{HOCH}(\mathrm{ONO}) \mathrm{CO}_{2}^{-}+\mathrm{H}_{2} \mathrm{O} \rightarrow \mathrm{HONO}+\mathrm{HOCH}(\mathrm{OH}) \mathrm{CO}_{2}^{-} \\
& \mathrm{HOCH}(\mathrm{OH}) \mathrm{CO}_{2}^{-}+\mathrm{OH}^{-} \rightarrow \mathrm{HOCH}\left(\mathrm{O}^{-}\right) \mathrm{CO}_{2}^{-}+\mathrm{H}_{2} \mathrm{O} \\
& \mathrm{HOCH}\left(\mathrm{O}^{-}\right) \mathrm{CO}_{2}^{-}+\mathrm{OH}^{-} \rightarrow \mathrm{HC}\left(\mathrm{O}^{-}\right)_{2} \mathrm{CO}_{2}^{-}+\mathrm{H}_{2} \mathrm{O} \\
& \mathrm{HC}\left(\mathrm{O}^{-}\right)_{2} \mathrm{CO}_{2}^{-}+\mathrm{H}_{2} \mathrm{O} \rightarrow{ }^{-} \mathrm{O}_{2} \mathrm{CCO}_{2}^{-}+\mathrm{OH}^{-}+\mathrm{H}_{2}
\end{aligned}
$$

Similarly, the aldehydes derived from the oxidation of the NPHs also participate in reactions that lead to the formation of hydrogen and sodium carboxylates:

$$
\begin{gathered}
\mathrm{RCH}_{2} \mathrm{ONO}+\mathrm{OH}^{-} \rightarrow \mathrm{RCHO}+\mathrm{NO}^{-}+\mathrm{H}_{2} \mathrm{O} \\
\mathrm{RCHO}+\mathrm{OH}^{-} \rightarrow \mathrm{RCHOH}\left(\mathrm{O}^{-}\right) \\
\mathrm{RCHOH}\left(\mathrm{O}^{-}\right)+\mathrm{OH}^{-} \rightarrow \mathrm{RCH}\left(\mathrm{O}_{2}^{-}\right)_{2}+\mathrm{H}_{2} \mathrm{O} \\
\mathrm{RCH}\left(\mathrm{O}^{-}\right)_{2}+\mathrm{H}_{2} \mathrm{O} \rightarrow \mathrm{RCO}_{2}^{-}+\mathrm{OH}^{-}+\mathrm{H}_{2}
\end{gathered}
$$

The reactions of the aldehydes, especially formaldehyde, with sodium hydroxide, rather than hydrogen atom abstraction reactions, are principally responsible for hydrogen generation in the waste.

Citrate ion and certain intermediate compounds undergo another type of base-catalyzed fragmentation. Study of the decomposition of the citrate ion in alkaline simulants in the absence of radiation has shown that it slowly undergoes fragmentation to acetate and oxalate ion (Ashby et al. 1994; Barefield et al. 1995, 1996). Little gas is formed, and the reaction is not catalyzed by sodium aluminate. These observations are accommodated by the formulation of the base-catalyzed thermal process as a reverse Claisen reaction (Lowry and Richardson 1987; Carey and Sundberg 1990; March 1992). The thermal relative rate data imply this reaction proceeds much more slowly than the decomposition of the glycolate ion in simulated waste.

$$
\begin{gathered}
\mathrm{HOC}\left(\mathrm{CH}_{2} \mathrm{CO}_{2}^{-}\right)_{2} \mathrm{CO}_{2}^{-}+\mathrm{OH}^{-} \rightarrow \mathrm{H}_{2} \mathrm{O}+{ }^{-} \mathrm{O}_{2} \mathrm{CCH}_{2} \mathrm{C}(=\mathrm{O}) \mathrm{CO}_{2}{ }^{-}+\mathrm{CH}_{3} \mathrm{CO}_{2}{ }^{-} \\
\mathrm{O}_{2} \mathrm{CCH}_{2} \mathrm{C}(=\mathrm{O}) \mathrm{CO}_{2}^{-}+\mathrm{OH}^{-} \rightarrow \mathrm{H}_{2} \mathrm{O}+{ }^{-} \mathrm{O}_{2} \mathrm{CCO}_{2}^{-}+\mathrm{CH}_{3} \mathrm{CO}_{2}{ }^{-}
\end{gathered}
$$

The reaction sequence accounts for the formation of acetate ions in the wastes. In principle, other appropriately constituted hydroxy compounds produced during thermal or radiolytic reactions could also undergo this reaction. However, virtually all these intermediates are polyfunctional molecules with alternative reaction paths.

3.3.5.3 Ionic Oxidation Reactions Catalyzed by Aluminate Ion. Delegard (1980, 1987) pointed out that the decomposition reactions of the organic complexants were promoted by aluminate, hydroxide, and nitrite ion. Ashby et al. (1994) and Barefield et al. $(1995,1996)$ also 


\section{RPP-6664 REV 0}

observed that the thermal reactions of glycolate ion were catalyzed by nitrite, aluminate, and hydroxide ions. The nature of the catalysis has not been established and several interpretations have been advanced for it. It has been suggested that nitrite esters nitrosate the complexants to provide nitroso compounds through ionic reaction pathways. (Barefield et al. 1995, 1996).

These reactions are usually formulated as NO transfer reactions between an inorganic ester and a carbanion to produce a $\mathrm{C}$-nitroso compound and liberate an alkoxide ion as outlined for the reaction of the anion of nitromethane with methyl nitrite:

$$
\begin{gathered}
\mathrm{CH}_{3} \mathrm{NO}_{2}+\mathrm{OH}^{-} \rightarrow \mathrm{H}_{2} \mathrm{O}+\mathrm{CH}_{2} \mathrm{NO}_{2}^{-} \\
\mathrm{CH}_{2} \mathrm{NO}_{2}^{-}+\mathrm{CH}_{3} \mathrm{ONO} \rightarrow \mathrm{ONCH}_{2} \mathrm{NO}_{2}^{-}+\mathrm{CH}_{3} \mathrm{O}^{-}
\end{gathered}
$$

Touser (1953) discussed the structural requirements for the reaction and pointed out that electron-withdrawing groups were required for nitrosation by nitrite esters. This structural requirement implies that carbanions need to be formed. However, the negatively charged complexants are very weak carbon acids and the concentrations of the required carbanions are very low. Also, the nitrite esters are hydrolyzed in alkaline solution maintaining their concentrations at low levels. It seems doubtful that $\mathrm{C}$-nitrosation reaction of a complexant could be accomplished under these circumstances with such low concentrations of the carbanions and the nitrite esters.

Other difficulties associated with the formulation of the reaction as a bimolecular nitrosation process have been discussed by Camaioni and Autrey (2000). Their work favors an alternative formulation that could account for the oxidation of glycolate ion. The chemistry is reminiscent of the Tischenko reaction (Jencks 1969; March 1992) and the Oppenauer oxidation (March 1992) in which the oxidation reduction reaction is accomplished by hydrogen transfer. The simultaneous bonding of a hydroxyl group of the organic complexant and nitrite ion to an aluminate ion provides a reasonable pathway for the assembly of the required reagents. The transfer of a hydrogen from the organic molecule to the nitrite ion in a conventional six-membered transition state accomplishes the oxidation-reduction reaction (Stock 1992). The reaction of glycolate ion is formulated to illustrate the process in the following equations, where " $L$ " is used to represent the other ligands on the aluminum atom.

$$
\begin{gathered}
\mathrm{L}_{2} \mathrm{Al}^{-}(\mathrm{OH})_{2}+\mathrm{NO}_{2}^{-} \rightarrow \mathrm{L}_{2} \mathrm{Al}^{-}(\mathrm{ONO})(\mathrm{OH})+\mathrm{HO}^{-} \\
\mathrm{O}_{2} \mathrm{CCH}_{2} \mathrm{OH}+\mathrm{L}_{2} \mathrm{Al}^{-}(\mathrm{ONO})(\mathrm{OH}) \rightarrow \mathrm{L}_{2} \mathrm{Al}^{-}(\mathrm{ONO})\left(\mathrm{OCH}_{2} \mathrm{CO}_{2}^{-}\right)+\mathrm{H}_{2} \mathrm{O} \\
\mathrm{L}_{2} \mathrm{Al}^{-}(\mathrm{ONO})\left(\mathrm{OCH}_{2} \mathrm{CO}_{2}{ }^{-}\right) \rightarrow \mathrm{OHCCO}_{2}^{-}+\mathrm{L}_{2} \mathrm{AlO}^{-}+\mathrm{NOH}
\end{gathered}
$$

This reaction sequence provides a pathway for the transformation of a hydroxyl group in a complexant, intermediate, or remnant into a carbonyl group. The occurrence of this reaction may contribute to the relatively rapid disappearance of glycolate ion from the waste (Barefield et al. 1995, 1996). However, the available evidence suggests the thermal oxidation reaction of HEDTA does not proceed in this way.

3.3.5.4 Reactions of C-Nitroso Compounds. Inasmuch as nitric oxide is ubiquitous in the wastes, the reaction pathway leading to C-nitroso compounds has been postulated as an important reaction pathway (Meisel et al. 1991a, 1991b, 1993, 1997, 2000; Camaioni et al. 1997, 1998). The products of these reactions rearrange to oximes that hydrolyze providing a carbonyl 
compound and hydroxylamine (Jencks 1969; Lowry and Richardson 1987; Carey and Sundberg 1990; March 1992). The conversions of the nitroso compounds obtained from a paraffinic hydrocarbon and glycolate and glycinate ions illustrate the chemistry:

$$
\begin{aligned}
& \mathrm{RCH}_{2} \mathrm{NO} \rightarrow \mathrm{RCH}=\mathrm{NOH} \\
& \mathrm{RCH}=\mathrm{NOH}+\mathrm{H}_{2} \mathrm{O} \rightarrow \mathrm{RCHO}+\mathrm{NH}_{2} \mathrm{OH} \\
& \mathrm{RCH}(\mathrm{NO}) \mathrm{CH}_{3} \rightarrow \mathrm{RC}(=\mathrm{NOH}) \mathrm{CH}_{3} \\
& \mathrm{RC}(=\mathrm{NOH}) \mathrm{CH}_{3}+\mathrm{H}_{2} \mathrm{O} \rightarrow \mathrm{RC}(=\mathrm{O}) \mathrm{CH}_{3}+\mathrm{NH}_{2} \mathrm{OH} \\
& \mathrm{HOCH}(\mathrm{NO}) \mathrm{CO}_{2}^{-} \rightarrow \mathrm{HOC}(=\mathrm{NOH}) \mathrm{CO}_{2}{ }^{-} \\
& \mathrm{HOC}(=\mathrm{NOH}) \mathrm{CO}_{2}^{-}+\mathrm{OH}^{-} \rightarrow \mathrm{O}_{2} \mathrm{CCO}_{2}^{-}+\mathrm{NH}_{2} \mathrm{OH} \\
& \mathrm{HOCH}_{2} \mathrm{NO} \rightarrow \mathrm{HOCH}(=\mathrm{NOH}) \\
& \mathrm{HOCH}(=\mathrm{NOH})+\mathrm{OH}^{-} \rightarrow \mathrm{HCO}_{2}^{-}+\mathrm{NH}_{2} \mathrm{OH} \\
& \mathrm{H}_{2} \mathrm{NCH}(\mathrm{NO}) \mathrm{CO}_{2}^{-} \rightarrow \mathrm{H}_{2} \mathrm{NC}(=\mathrm{NOH}) \mathrm{CO}_{2}^{-} \\
& \mathrm{H}_{2} \mathrm{NC}(=\mathrm{NOH}) \mathrm{CO}_{2}^{-}+\mathrm{OH}^{-} \rightarrow \mathrm{H}_{2} \mathrm{NC}(=\mathrm{O}) \mathrm{CO}_{2}^{-}+\mathrm{NH}_{2} \mathrm{O}^{-} \\
& \mathrm{H}_{2} \mathrm{NC}(=\mathrm{O}) \mathrm{CO}_{2}^{-}+\mathrm{NH}_{2} \mathrm{O}^{-}+\mathrm{H}_{2} \mathrm{O} \rightarrow{ }^{-} \mathrm{O}_{2} \mathrm{CCO}_{2}^{-}+\mathrm{NH}_{3}+\mathrm{NH}_{2} \mathrm{OH} \\
& \mathrm{H}_{2} \mathrm{NCH}_{2} \text { (NO) } \rightarrow \mathrm{H}_{2} \mathrm{NCH}(=\mathrm{NOH}) \\
& \mathrm{H}_{2} \mathrm{NCH}(=\mathrm{NOH})+\mathrm{OH}^{-} \rightarrow \mathrm{H}_{2} \mathrm{NCH}(=\mathrm{O})+\mathrm{NH}_{2} \mathrm{O}^{-} \\
& \mathrm{H}_{2} \mathrm{NCH}(=\mathrm{O})+\mathrm{NH}_{2} \mathrm{O}^{-}+\mathrm{H}_{2} \mathrm{O} \rightarrow \mathrm{HCO}_{2}^{-}+\mathrm{NH}_{2} \mathrm{OH}+\mathrm{NH}_{3}
\end{aligned}
$$

Isomerization to the more thermodynamically stable oxime occurs in the first step. Hydrolysis is shown in the next one or two reactions. The hydrocarbons provide aldehydes or ketones. But some complexants yield amides, hydroxamate ions, or their analogues. Barefield et al. (1995) note that benzylhydroxamate hydrolyzes slowly (Brendt and Fuller 1966), whereas the simplest hydroxamate, the hydroxamate of formate ion, hydrolyzes in minutes in $2.0 \mathrm{M}$ sodium hydroxide at $60^{\circ} \mathrm{C}$ :

$$
\mathrm{HCONHOH}+\mathrm{H}_{2} \mathrm{O} \rightarrow \mathrm{HCO}_{2}^{-}+\mathrm{NH}_{2} \mathrm{OH}
$$

The simplest amide, formamide, is also rapidly decomposed in alkaline solution.

In a targeted investigation, Ashby et al. (1994) showed that formadehyde reacted rapidly with hydroxylamine to form the expected oxime and that this compound then reacted to form sodium cyanide, which subsequently gave formate ion and ammonia:

$$
\begin{aligned}
& \mathrm{H}_{2} \mathrm{CO}+\mathrm{NH}_{2} \mathrm{OH} \rightarrow \mathrm{H}_{2} \mathrm{C}=\mathrm{NOH}+\mathrm{H}_{2} \mathrm{O} \\
& \mathrm{H}_{2} \mathrm{C}=\mathrm{NOH}+\mathrm{NaOH} \rightarrow \mathrm{NaCN}+2 \mathrm{H}_{2} \mathrm{O} \\
& \mathrm{NaCN}+2 \mathrm{H}_{2} \mathrm{O} \rightarrow \mathrm{Na}^{+}+\mathrm{HCO}_{2}^{-}+\mathrm{NH}_{3}
\end{aligned}
$$

The reactions of the oxidized paraffinic hydrocarbons proceed at least in part in this way to form the homologous series of nitriles observed in the wastes. 
Whether the reaction occurs by dehydration or by hydrolysis, the main carbon-containing products of the complexants are oxalate or formate ions. The gas-forming reactions of hydroxylamine are discussed later in this document, but it is pertinent to note that the nitrogen atom from the complexant evolves as ammonia, and the nitrogen atom from nitrous oxide (i.e. nitrite ion) becomes the nitrogen atom in hydroxylamine.

3.3.5.5 Reactions of C-Nitro Compounds. The C-nitro compounds formed during the radical reactions also contain two electronegative atoms bonded to a tetrahedral carbon atom and are therefore susceptible to the decomposition reactions discussed for other substances with two electronegative groups. However, the nitro compounds also contain acidic hydrogen atoms that can be abstracted by the hydroxide ions in the alkaline waste (Lowry and Richardson 1987; Carey and Sundberg 1990; March 1992). The anionic substances are quite reactive and readily undergo several different reactions.

The decomposition of the nitro compound in aqueous media provides an oxidized organic product with a carbonyl group and the reduced nitrosyl anion, which spontaneously produces nitrous oxide (Noland, 1955; Hawthorne 1957; Pinnick 1990; March 1992). This reaction usually is carried out in acidic solution, but there are many examples of the reaction in alkaline media (Pinnick 1990). The reaction is usually formulated as shown in the equations illustrating the chemistry of the paraffinic hydrocarbons and the complexants:

$$
\begin{aligned}
& \mathrm{RCH}_{2} \mathrm{NO}_{2}+\mathrm{OH}^{-} \rightarrow \mathrm{RCHNO}_{2}^{-}+\mathrm{H}_{2} \mathrm{O} \\
& \mathrm{RCHNO}_{2}^{-}+\mathrm{H}_{2} \mathrm{O} \rightarrow \mathrm{RCHO}+\mathrm{NO}^{-}+\mathrm{H}_{2} \mathrm{O} \\
& \mathrm{RCH}\left(\mathrm{NO}_{2}\right) \mathrm{CH}_{3}+\mathrm{OH}^{-} \rightarrow \mathrm{RC}\left(\mathrm{NO}_{2}{ }^{-}\right) \mathrm{CH}_{3}+\mathrm{H}_{2} \mathrm{O} \\
& \mathrm{RC}\left(\mathrm{NO}_{2}{ }^{-}\right) \mathrm{CH}_{3}+\mathrm{H}_{2} \mathrm{O} \rightarrow \mathrm{RC}(=\mathrm{O}) \mathrm{CH}_{3}+\mathrm{NO}^{-}+\mathrm{H}_{2} \mathrm{O} \\
& \mathrm{HOCH}\left(\mathrm{NO}_{2}\right) \mathrm{CO}_{2}^{-}+\mathrm{OH}^{-} \rightarrow \mathrm{HOC}\left(\mathrm{NO}_{2}^{-}\right) \mathrm{CO}_{2}^{-}+\mathrm{H}_{2} \mathrm{O} \\
& \mathrm{HOC}\left(\mathrm{NO}_{2}{ }^{-}\right) \mathrm{CO}_{2}{ }^{-}+\mathrm{OH}^{-} \rightarrow{ }^{-} \mathrm{O}_{2} \mathrm{CCO}_{2}^{-}+\mathrm{NO}^{-}+\mathrm{H}_{2} \mathrm{O} \\
& \mathrm{HOCH}_{2} \mathrm{NO}_{2}+\mathrm{OH}^{-} \rightarrow \mathrm{HOCH}\left(\mathrm{NO}_{2}{ }^{-}\right)+\mathrm{H}_{2} \mathrm{O} \\
& \mathrm{HOCH}\left(\mathrm{NO}_{2}{ }^{-}\right)+\mathrm{OH}^{-} \rightarrow \mathrm{HCO}_{2}^{-}+\mathrm{NO}^{-}+\mathrm{H}_{2} \mathrm{O} \\
& \mathrm{H}_{2} \mathrm{NCH}\left(\mathrm{NO}_{2}\right) \mathrm{CO}_{2}^{-}+\mathrm{OH}^{-} \rightarrow \mathrm{H}_{2} \mathrm{NC}\left(\mathrm{NO}_{2}{ }^{-}\right) \mathrm{CO}_{2}^{-}+\mathrm{H}_{2} \mathrm{O} \\
& \mathrm{H}_{2} \mathrm{NC}\left(\mathrm{NO}_{2}{ }^{-}\right) \mathrm{CO}_{2}^{-} \rightarrow \mathrm{H}_{2} \mathrm{NC}(=\mathrm{O}) \mathrm{CO}_{2}^{-}+\mathrm{NO}^{-} \\
& \mathrm{H}_{2} \mathrm{NC}(=\mathrm{O}) \mathrm{CO}_{2}^{-}+\mathrm{OH}^{-} \rightarrow{ }^{-} \mathrm{O}_{2} \mathrm{CCO}_{2}^{-}+\mathrm{NH}_{3}+\mathrm{H}_{2} \mathrm{O} \\
& \mathrm{H}_{2} \mathrm{NCH}_{2}(\mathrm{NO})+\mathrm{OH}^{-} \rightarrow \mathrm{H}_{2} \mathrm{NCH}\left(\mathrm{NO}_{2}{ }^{-}\right)+\mathrm{H}_{2} \mathrm{O} \\
& \mathrm{H}_{2} \mathrm{NCH}\left(\mathrm{NO}_{2}{ }^{-}\right) \rightarrow \mathrm{H}_{2} \mathrm{NCH}(=\mathrm{O})+\mathrm{NO}^{-} \\
& \mathrm{H}_{2} \mathrm{NCH}(=\mathrm{O})+\mathrm{OH}^{-} \rightarrow \mathrm{HCO}_{2}^{-}+\mathrm{NH}_{3}
\end{aligned}
$$

The chemistry of the nitrosyl anion, which leads directly to nitrous oxide, is discussed in Section 4.3.

An early review of the chemistry of aliphatic nitro compounds indicates that the anions readily undergo nitrosation (Touser 1953). Secondary nitro compounds yield C-nitroso compounds. The primary nitro compounds also yield C-nitroso compounds, but these substances convert to 
oxime derivatives. The products of the complexants have several electronegative groups bonded to a single carbon and are unstable in alkaline solution, as illustrated for the secondary C-nitro derivative of glycolate ion and the primary C-nitro derivative of EDTA:

$$
\begin{gathered}
\mathrm{HOC}\left(\mathrm{NO}_{2}{ }^{-}\right) \mathrm{CO}_{2}{ }^{-}+\mathrm{NO} \rightarrow \mathrm{HOC}(\mathrm{NO})\left(\mathrm{NO}_{2}{ }^{-}\right) \mathrm{CO}_{2}^{-} \\
\left(\mathrm{O}_{2} \mathrm{CCH}_{2}\right)_{2} \mathrm{NCH}_{2} \mathrm{CH}_{2} \mathrm{~N}\left(\mathrm{CH}_{2} \mathrm{CO}_{2}{ }^{-}\right)\left(\mathrm{CHNO}_{2}{ }^{-}\right)+\mathrm{NO} \rightarrow \\
\left(\mathrm{O}_{2} \mathrm{CCH}_{2}\right)_{2} \mathrm{NCH}_{2} \mathrm{CH}_{2} \mathrm{~N}\left(\mathrm{CH}_{2} \mathrm{CO}_{2}^{-}\right)\left(\mathrm{CH}(\mathrm{NO}) \mathrm{NO}_{2}{ }^{-}\right) \\
\left(\mathrm{O}_{2} \mathrm{CCH}_{2}\right)_{2} \mathrm{NCH}_{2} \mathrm{CH}_{2} \mathrm{~N}\left(\mathrm{CH}_{2} \mathrm{CO}_{2}{ }^{-}\right)\left(\mathrm{CH}(\mathrm{NO}) \mathrm{NO}_{2}{ }^{-}\right) \rightarrow \\
\left.\left(\mathrm{O}_{2} \mathrm{CCH}_{2}\right)_{2} \mathrm{NCH}_{2} \mathrm{CH}_{2} \mathrm{~N}\left(\mathrm{CH}_{2} \mathrm{CO}_{2}{ }^{-}\right)(\mathrm{C}=\mathrm{NOH}) \mathrm{NO}_{2}{ }^{-}\right)
\end{gathered}
$$

These substances are hydrolyzed to form oxidized molecules containing carbonyl groups and reduced inorganic nitrogen derivatives. The $C$-nitration of glycolate ion followed by C-nitrosation and electron transfer would convert glycolate ion into oxalate ion and hydroxylamine. The same sequence of reactions would convert the EDTA derivative into ED3A, carbonate ion, and hydroxylamine.

Investigations of the chemistry of nitrogen dioxide and nitric oxide have demonstrated that the salt of nitromethane reacts with both substances in alkaline solution to form even more oxidized products with two nitro groups or one nitro and one nitroso group bonded to the same carbon atom (Reszka et al. 1996). This work suggests that the nitro compounds formed in the Hanford Site waste may react similarly because of the high concentrations of nitric oxide and nitrogen dioxide. However, no compounds with two nitro groups, or two nitroso groups, or one nitroso group and one nitro group have been detected in the dome spaces of the 110 waste tanks that have been investigated.

The chemistry of substances produced in these reactions has not specifically been investigated. However, it is evident that the initial products, which are anion radicals, would have a rich chemistry in the aqueous alkaline waste solutions. For example, the decomposition of the anion radical formed by the loss of nitrite ion would provide a nitroso derivative related to the oxime discussed in the previous section. Simple electron transfer converts the products into molecules with three electronegative atoms bonded to the same reactive carbon atom. Such compounds should have relatively short lifetimes in the waste, and since the reactive carbon atom in these substances is in the oxidation state of the carbon atom in a carboxyl group, hydrolysis would produce a carboxylate anion.

3.3.5.6 Reactions of Compounds with Oxidized Amino Groups. Although nitrogen-centered radicals do not form from the original complexants, they can be obtained from remnants such as IDA and glycinate ion, which have primary and secondary amino groups. Recombination reactions of the nitrogen-centered radicals with nitrite ion, nitric oxide, nitrogen dioxide, and hydroxyl radicals provide the oxidized intermediate organic compounds with $\mathrm{N}$-oxygen and $\mathrm{N}$-nitrogen bonds shown in Tables 3-7, 3-8, and 3-9.

Although there have been no targeted investigations to define the behavior of these substances in Hanford Site waste, studies of their chemistry in the chemical literature imply they are not stable in alkaline solutions. The nitrite ester obtained in the reaction with nitrogen dioxide is 
hydrolyzed to the hydroxyl amine. This behavior is illustrated by the reactions of the glycinate derivatives in the following equations:

$$
\mathrm{ONONHCH}_{2} \mathrm{CO}_{2}^{-}+\mathrm{OH}^{-} \rightarrow \mathrm{ONO}^{-}+\mathrm{HONHCH}_{2} \mathrm{CO}_{2}^{-}
$$

The $\mathrm{N}$-hydroxyl compound obtained in this reaction is also produced in the recombination reaction with hydroxyl radical. These hydroxylamines are converted in an alkaline solution into imines that hydrolyze to form ammonia and aldehydes:

$$
\begin{gathered}
\mathrm{HONHCH}_{2} \mathrm{CO}_{2}^{-} \rightarrow \mathrm{H}_{2} \mathrm{O}+\mathrm{HN}=\mathrm{CHCO}_{2}^{-} \\
\mathrm{HN}=\mathrm{CHCO}_{2}^{-}+\mathrm{H}_{2} \mathrm{O} \rightarrow \mathrm{NH}_{3}+\mathrm{O}=\mathrm{CHCO}_{2}^{-}
\end{gathered}
$$

The $\mathrm{N}$-nitroso compound is converted into glycolate ion and nitrogen through several proton transfer reactions to eventually provide the diazohydroxide and diazonium hydroxide shown in the equations:

$$
\begin{gathered}
\mathrm{ONNHCH}_{2} \mathrm{CO}_{2}^{-} \rightarrow \mathrm{HON}=\mathrm{NCH}_{2} \mathrm{CO}_{2}^{-} \\
\mathrm{HON}=\mathrm{NCH}_{2} \mathrm{CO}_{2}^{-} \rightarrow \mathrm{HO}^{-}+\mathrm{N}_{2}^{+} \mathrm{CH}_{2} \mathrm{CO}_{2}^{-} \\
\mathrm{N}_{2}^{+} \mathrm{CH}_{2} \mathrm{CO}_{2}^{-}+\mathrm{OH}^{-} \rightarrow \mathrm{N}_{2}+\mathrm{HOCH}_{2} \mathrm{CO}_{2}^{-}
\end{gathered}
$$

The related decomposition of the N-nitro compound, which begins with the removal of the acidic proton from nitrogen, provides glycolate ion and nitrous oxide:

$$
\begin{gathered}
\mathrm{O}_{2} \mathrm{NNHCH}_{2} \mathrm{CO}_{2}^{-}+\mathrm{HO}^{-} \rightarrow \mathrm{H}_{2} \mathrm{O}+\mathrm{O}_{2} \mathrm{~N}=\mathrm{NCH}_{2} \mathrm{CO}_{2}^{-} \\
\mathrm{O}_{2} \mathrm{~N}=\mathrm{NCH}_{2} \mathrm{CO}_{2}^{-} \rightarrow \mathrm{HO}^{-}+\mathrm{O}=\mathrm{NN}=\mathrm{CHCO}_{2}^{-} \\
\left.\mathrm{O}=\mathrm{NN}=\mathrm{CHCO}_{2}^{-}+\mathrm{H}_{2} \mathrm{O} \rightarrow \mathrm{N}_{2} \mathrm{O}+\mathrm{H}\right) \mathrm{CH}_{2} \mathrm{CO}_{2}^{-}
\end{gathered}
$$

The highly unsaturated intermediates would react very rapidly with nitric oxide and nitrogen dioxide. These reaction pathways eventually lead to the same more highly oxidized substances, glyoxalate and oxalate ion, as formed in the other oxidation reactions of carbon.

\subsection{SUMMARY}

The results of the fundamental and targeted investigations provide a framework for the definition of the reaction pathways by which the organic complexants and solvents are oxidized. Indeed, the work has resulted in the formulation of a chemical model with relatively long sequences of chemical reactions that eventually lead to carbonate ion as the final product of organic oxidation. Insofar as the gases are concerned, hydrogen is a byproduct of the chemistry in which the inorganic oxidants are reduced to form nitrogen-containing gases.

The chemical model for the oxidation reactions of the organic molecules centers on three distinctly different initiation processes. Two initiation pathways involve radicals produced by the radiolysis of concentrated aqueous solutions of sodium nitrite and nitrate or by the thermal 


\section{RPP-6664 REV 0}

decomposition of chemical substances in the waste. The initial radiolytic processes have negligible activation energies, but the thermally initiated reactions have high activation energies. The reactive inorganic radicals either abstract a hydrogen atom or an electron from the organic constituents to produce free radicals. The organic radicals subsequently recombine with nitric oxide, nitrogen dioxide, and other substances to form more oxidized organic intermediates. The third initiation pathway involves reactions between the ionic inorganic substances present in the waste and the organic molecules. These reactions, which are temperature dependent, also lead to oxidized organic intermediates.

Many of the intermediate organic compounds, particularly the nitrite and nitrate esters and the $\mathrm{C}$-nitroso and $\mathrm{C}$-nitro compounds, provided by three different initiation pathways are more reactive than the original solvents and complexants. Consequently, the intermediates undergo additional reactions to give relatively stable remnant molecules including NTA, IDA, and glycinate ion, formate, and oxalate ion in the case of the complexants, and homologous families of alkanes, alkenes, alcohols, aldehydes and ketones, and nitriles in the case of the solvents. The entire family of organic intermediates and the metastable end products are susceptible to the same sets of initiation reactions as the original complexants and solvents.

The chemical model, some elements of which have been presented in a quantitative format, is fully consistent with the results of characterization work establishing the presence of remnant molecules and metastable end products of the oxidation reaction in tank waste, as well as with the fundamental and targeted investigations carried out in the laboratory. Finally, it is gratifying that some elements of the chemical model have been incorporated into predictive quantitative models. 
RPP-6664 REV 0

\subsection{GAS FORMATION}

\subsection{INTRODUCTION}

As discussed in Section 1.0, hydrogen, nitrogen, nitrous oxide, and ammonia are found in the dome spaces of waste tanks and in the condensed wastes (Johnson et al. 1997; Shekarriz et al. 1997; McCain 1999; Mahoney et al. 1999, 2000). Hydrogen is slowly produced as a byproduct of the corrosion of the steel tank walls. Hydrogen and the other gases also are formed as a consequence of radiolysis and the ensuing oxidation reactions of the organic constituents in the waste that were examined in Section 2.0. Nitrogen and nitrous oxide are formed principally from the inorganic oxidants as byproducts of the oxidation of organic constituents. Ammonia is produced from the nitrogen-containing complexants and from the inorganic oxidants. These conclusions are based upon studies of the chemical behavior of the complexants in well-defined reactions conducted by university and national laboratory teams and upon targeted investigations of the processes governing gas formation in complex simulants and very heterogeneous wastes (Ashby et al. 1993, 1994; Barefield et al. 1995, 1996; Bryan et al. 1996, 1997; Camaioni et al. 1998; Camaioni and Autrey 2000; Delegard 1980, 1987; Johnson et al. 1997; King et al. 1997; King and Bryan 1999; Meisel et al. 1991a, 1991b, 1993, 1997, 2000; Person 1996, 1998). Observations that provide insight into the factors governing gas-forming reactions during interim storage and operations are examined in this section. The empirical findings establishing the origins of hydrogen and the nitrogen-containing gases are discussed in Sections 4.2 and 4.3; the rates and activation parameters for gas generation in waste are examined in Section 4.4; and the chemical origins of the gas are discussed in Section 4.5. The relationship between gas formation and organic compound oxidation is examined in Section 4.6. The reactions between the gases and gas solubility are described in Sections 4.7 and 4.8 .

\subsection{ORIGINS OF HYDROGEN}

\subsubsection{Hydrogen from the Corrosion of Steel}

Mild steel readily corrodes in acidic and neutral solutions, and the corrosion rates could exceed $0.025 \mathrm{~mm} / \mathrm{yr}$ (1 mil/yr) (Pourbaix 1974; Elmore 1997). However, the rate of corrosion occurs much more slowly at high $\mathrm{pH}$. Conservative estimates suggest the corrosion rate is $0.0025 \mathrm{~mm} / \mathrm{yr}$ (0.1 mil/yr) (Hopkins 1994, 1995; Hu et al. 1997; Anantatmula 1999). Experimental work in which the steels used in the double-shell tanks were placed in contact with simulated waste and irradiated suggests the rate is between $0.00050 \mathrm{~mm} / \mathrm{yr}$ and $0.00075 \mathrm{~mm} / \mathrm{yr}(0.02 \mathrm{mil} / \mathrm{yr}$ and $0.03 \mathrm{mil} / \mathrm{yr}$ ) (Strachan 1994). Knowledge of the rate of corrosion coupled with the stoichoimetric relationship between iron oxidation and hydrogen generation provides an approach with which to estimate the amount of hydrogen generated by corrosion:

$$
\mathrm{Fe}+2 \mathrm{H}_{2} \mathrm{O} \rightarrow \mathrm{Fe}(\mathrm{OH})_{2}+\mathrm{H}_{2}
$$

The amount of hydrogen generated by corrosion is sometimes a small fraction of the total amount of hydrogen generated in a tank. For tank $241-S Y-101$, it is about $3 \%$ of the total. 


\section{RPP-6664 REV 0}

However, this fraction is highly variable because the rates of the thermal and radiolytic generation of hydrogen, as discussed in Section 5.0, vary substantially. When the conditions are unfavorable for the formation of hydrogen from water or organic molecules, corrosion can become the dominant reaction for hydrogen formation.

\subsubsection{Hydrogen from the Radiolysis of Water}

Molecular hydrogen and six other reactive substances are formed during the radiolysis of water (Spinks and Woods 1990). The observations in Table 4-1 indicate that the yields of these substances change during the early stages of the reaction.

Table 4-1. Generation Efficiency Values in Molecules per100 Electron-Volts for the Initial Products of the Radiolysis of Pure Water.

\begin{tabular}{|l|c|c|}
\hline \multicolumn{1}{|c|}{ Product } & G Value at 1 picosecond & G Value at 100 nanoseconds \\
\hline Solvated electron & 4.78 & 2.70 \\
\hline Proton & 4.78 & 2.70 \\
\hline Hydrogen atom & 0.62 & 0.61 \\
\hline Hydroxyl radical & 5.70 & 2.87 \\
\hline Hydrogen & 0.15 & 0.45 \\
\hline Hydrogen peroxide & no data & 0.61 \\
\hline Hydroperoxy radical & no data & 0.026 \\
\hline
\end{tabular}

Note: Information in this table is from Spinks, J. T. W., and R. J. Woods, 1990, An Introduction to Radiation Chemistry, John Wiley and Sons, New York.

$\mathrm{G}=$ molecules $/ 100 \mathrm{eV}$.

Hydrogen generation efficiency $-\mathrm{G}\left(\mathrm{H}_{2}\right)$ - has been determined for many different conditions. The $G$ value for pure water is 0.45 (Spinks and Woods 1990). However, hydrogen atoms and solvated electrons are consumed in the presence of nitrate and nitrate ions, and the yield of molecular hydrogen is reduced considerably in the presence of these substances. An empirical expression for $\mathrm{G}\left(\mathrm{H}_{2}\right)$ for radiolysis in sodium nitrate and sodium nitrate solutions was given by Tabata et al. (1991):

$$
\mathrm{G}\left(\mathrm{H}_{2}\right)=0.45-0.31\left[\mathrm{NO}_{2}{ }^{-}\right]^{1 / 3}-0.41\left[\mathrm{NO}_{3}{ }^{-}\right]^{1 / 3}
$$

$\mathrm{Hu}(2000)$ examined the applicability of this expression for the calculation of hydrogen generation from tank 241-AY-102, which does not contain organic waste, and found the equation overestimated the hydrogen yield. The coefficients appropriate for the waste in tank 241-AY-102 are shown in the following equation:

$$
\mathrm{G}\left(\mathrm{H}_{2}\right)=0.45-0.56\left[\mathrm{NO}_{2}{ }^{-}\right]^{1 / 3}-0.43\left[\mathrm{NO}_{3}{ }^{-1 / 3}\right.
$$

Meisel et al. (1991a, 1991b, 1993, 1997) reported that $\mathrm{G}\left(\mathrm{H}_{2}\right)$ for a waste simulant containing sodium nitrite and sodium nitrate, but no organic compounds, was 0.031 . 


\section{RPP-6664 REV 0}

\subsubsection{Hydrogen from Organic Compounds}

Meisel et al. (1991a, 1991b, 1993) also observed that hydrogen yields were enhanced in the presence of organic compounds. Investigations of the complexants and their remnants revealed a linear relationship between $\mathrm{G}\left(\mathrm{H}_{2}\right)$ and the number of carbon-hydrogen and nitrogen-hydrogen bonds in the complexants (see Figure 4-1).

Figure 4-1. The Relationship Between Hydrogen Generation Efficiency and the Number of Carbon-Hydrogen and Nitrogen-Hydrogen Bonds in Organic Complexants.

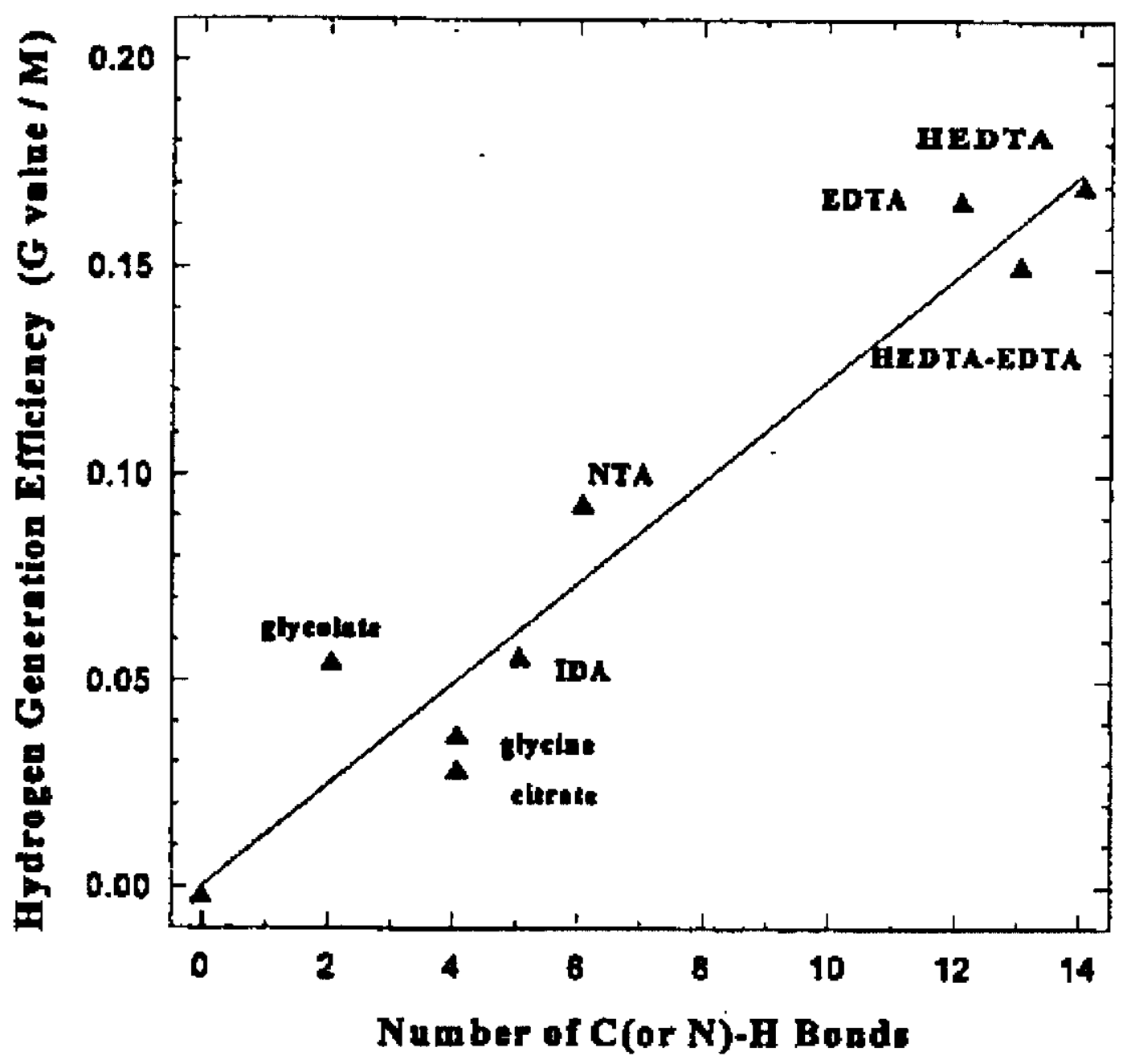

The analytical expression describing the hydrogen yield for simulants rich in nitrate and nitrite ions has a first-order dependence on the concentration of the organic constituents:

$$
\mathrm{G}\left(\mathrm{H}_{2}\right)=0.031+0.013 \mathrm{n}_{(\mathrm{CH}+\mathrm{NH})}[\text { complexant concentration] }
$$

where $\mathrm{n}_{(\mathrm{CH}+\mathrm{NH})}$ is the sum of carbon-hydrogen and nitrogen-hydrogen bonds in the molecule, and the complexant concentration is given in moles per liter. This empirical correlation has been widely employed in models describing the generation of hydrogen. 


\section{RPP-6664 REV 0}

\subsection{ORIGINS OF NITROGEN-CONTAINING GASES}

Three nitrogen-containing gases, nitrous oxide, nitrogen, and ammonia, evolve from the Hanford Site wastes. Other nitrogen-containing gases, such as nitric oxide and nitrogen dioxide, also are formed, but these reactive substances are consumed within the waste under the present storage conditions. The $\mathrm{G}$ values for the formation of nitrous oxide, nitrogen, and ammonia in Hanford Site waste simulants have not been investigated to the same extent as those for hydrogen. The available results for nitrous oxide and nitrogen are shown in Tables 4-2 and 4-3.

Table 4-2. Generation Efficiency Values in Molecules per100 Electron-Volts for the Formation of Nitrous Oxide in Waste Simulants.

\begin{tabular}{|c|c|c|c|c|}
\hline Organic Compound & $\begin{array}{c}\text { Concentration } \\
(\mathbf{M})\end{array}$ & $\begin{array}{c}\mathbf{G}\left(\mathbf{N}_{\mathbf{2}} \mathbf{O}\right) \\
\mathbf{a t} \mathbf{3 0}\end{array}$ & $\begin{array}{c}\mathbf{G}\left(\mathbf{N}_{\mathbf{2}} \mathbf{O}\right) \\
\mathbf{a t} \mathbf{6 0} \mathbf{C}\end{array}$ & Note \\
\hline None & 0.00 & 0.00 & 0.00 & 1 \\
\hline Glycolate & 0.30 & 0.42 & 0.86 & 1 \\
\hline Citrate & 0.17 & 0.045 & 0.064 & 1 \\
\hline EDTA & 0.085 & 0.60 & 1.10 & 1 \\
\hline HEDTA & 0.085 & 0.50 & 0.77 & 1 \\
\hline NTA & 0.17 & 0.56 & 0.48 & 1 \\
\hline IDA & 0.17 & 0.76 & 0.94 & 1 \\
\hline Glycine & 0.30 & 0.15 & 0.47 & 1 \\
\hline Simulant POC & & 0.49 & 0.87 & 1,3 \\
\hline Simulant POI & & 0.48 & 1.06 & 1,4 \\
\hline Simulant PAS & & 0.17 & & 2,5 \\
\hline
\end{tabular}

Note 1: Meisel, D., H. Diamond, E. P. Horwitz, C. D. Jonah, M. S. Matheson, M. C. Sauer, Jr., and J. C. Sullivan, 1991a, Radiation Chemistry of Synthetic Waste, ANL-91/40, Argonne National Laboratory, Argonne, Illinois.

Note 2: Camaioni, D. M., W. D. Samuels, S. A. Clauss, J. C. Lenihan, K. L. Wahl, J. A. Campbell, and W. J. Shaw, 1995, Organic Tanks Safety Program FY95 Waste Aging Studies, PNL-10794, Pacific Northwest Laboratory, Richland, Washington.

Note 3: The POC simulant contains the sodium salts of $0.065 \mathrm{M}$ EDTA, $0.065 \mathrm{M}$ HEDTA, and $0.1 \mathrm{M}$ citrate ion.

Note 4: The POI simulant was prepared by irradiating (31.5 Mrad) and degassing the POC simulant.

Note 5: The PAS simulant contains the sodium salts of 0.02M EDTA, $0.11 \mathrm{M}$ HEDTA, and $0.12 \mathrm{M}$ citrate, and $0.30 \mathrm{M}$ glycolate.

$$
\begin{array}{llll}
\text { EDTA } & =\text { ethylenediaminetetraacetate ion. } & M & =\text { moles per liter. } \\
\text { HEDTA } & =\text { hydroxyethylethylenediaminetriacetate ion. } & \text { NTA } & =\text { nitrilotriacetate ion. } \\
\text { IDA } & =\text { iminodiacetate ion. }
\end{array}
$$




\section{RPP-6664 REV 0}

Table 4-3. Generation Efficiency Values in Molecules per 100 Electron-Volts for the Formation of Nitrogen in Waste Simulants.

\begin{tabular}{|c|c|c|c|}
\hline Experimental Sample & $\begin{array}{l}\text { Temperature } \\
\text { (C) }\end{array}$ & $\mathbf{G}\left(\mathbf{N}_{2}\right)$ & Note \\
\hline Simulant without organic compounds in $\mathrm{N}_{2} \mathrm{O}$ & 30 & $0.0018 \pm 0.0005$ & 1 \\
\hline $\begin{array}{l}\text { Simulant with } 0.065 M \text { EDTA, } 0.065 M \\
\text { M HEDTA, and } 0.1 M \text { citrate ion in } \mathrm{N}_{2} \mathrm{O}\end{array}$ & 30 & $0.012 \pm 0.002$ & 1 \\
\hline Simulant POI & 60 & 0.13 & 1,4 \\
\hline $\begin{array}{l}\text { Simulant with } 0.065 M \text { EDTA, } 0.065 M \\
\text { HEDTA, and } 0.1 M \text { citrate ion in argon }\end{array}$ & 30 & $0.014 \pm 0.002$ & 1 \\
\hline Simulant with $0.3 M$ glycine in argon & 60 & 0.07 & 1 \\
\hline Simulant PAS & N/A & 0.08 & $2,3,4$ \\
\hline
\end{tabular}

Note 1: Meisel, D., H. Diamond, E. P. Horwitz, C. D. Jonah, M. S. Matheson, M. C. Sauer, Jr., and

J. C. Sullivan, 1991a, Radiation Chemistry of Synthetic Waste, ANL-91/40, Argonne National Laboratory, Argonne, Illinois.

Note 2: Camaioni, D. M., W. D. Samuels, S. A. Clauss, J. C. Lenihan, K. L. Wahl, J. A. Campbell, and W. J. Shaw, 1995, Organic Tanks Safety Program FY95 Waste Aging Studies, PNL-10794, Pacific Northwest Laboratory, Richland, Washington.

Note 3: The reaction was examined at $50^{\circ} \mathrm{C}, 70^{\circ} \mathrm{C}$, and $90^{\circ} \mathrm{C}$.

Note 4: The POC simulant contains the sodium salts of $0.065 M$ EDTA, $0.065 M$ HEDTA, and $0.1 M$ citrate ion. The POI simulant was prepared by irradiating $(31.5 \mathrm{Mrad})$ and degassing the POC simulant. The PAS simulant contains the sodium salts of $0.02 M$ EDTA, $0.11 \underline{M}$ HEDTA, and $0.12 M$ citrate, and $0.30 M$ glycolate.

$$
\begin{aligned}
& \text { EDTA }=\text { ethylenediaminetetraacetate ion. } \quad M=\text { moles per liter. } \\
& \text { HEDTA }=\text { hydroxyethylethylenediaminetriacetate ion. } \quad \text { N/A }=\text { not applicable. } \\
& \text { IDA = iminodiacetate ion. NTA }=\text { nitrilotriacetate ion. }
\end{aligned}
$$

Meisel et al. (1991a, 1991b, 1993) found that nitrous oxide was not formed in simulants when organic compounds were excluded. Evaluation of the analytical procedures suggests $\mathrm{G}$ values as low as 0.001 can be measured. They found $\mathrm{G}\left(\mathrm{N}_{2} \mathrm{O}\right)$ increased appreciably when organic complexants were present, but the different complexants showed significant differences in the $\mathrm{G}$ values, as shown in Table 4-2. The large yield of nitrous oxide obtained with the glycolate ion indicates that the nitrogen atoms in nitrous oxide are provided by the nitrogen atoms in the inorganic constituents. This observation was confirmed by the study of nitrogen-15-labeled glycine. It was found that not more than $2.6 \%$ of the nitrogen in nitrous oxide was obtained from the organic amino group. This work with the inorganic reagents also indicated that the nitrite ion was much more reactive than the nitrate ion and was the principal source of both nitrogen atoms in the gas.

Although the presence of organic compounds was necessary for the formation of nitrous oxide, Meisel et al. (1991a, 1991b, 1993) found that the relationship between the yields of the gas and the concentrations of the organic constituents was complex. There was no simple empirical relationship between $\mathrm{G}\left(\mathrm{N}_{2} \mathrm{O}\right)$ and the concentration of the organic compounds. The problem was acerbated by the finding that $\mathrm{G}\left(\mathrm{N}_{2} \mathrm{O}\right)$ depended upon the dose rate at $30^{\circ} \mathrm{C}$. In addition, the $\mathrm{G}$ values at $30^{\circ} \mathrm{C}$ and at $60^{\circ} \mathrm{C}$ differ significantly, suggesting that temperature-dependent chemical processes not requiring radiation influence the chemical outcome. 


\section{RPP-6664 REV 0}

The $\mathrm{G}\left(\mathrm{N}_{2}\right)$ values summarized in Table 4-3 indicate that the inorganic constituents are converted into nitrogen in very low yield in the absence of organic compounds. The nitrogen yield increases by a factor of 10 in the presence of organic complexants, but $\mathrm{G}\left(\mathrm{N}_{2}\right)$ is only $10 \%$ of $\mathrm{G}\left(\mathrm{N}_{2} \mathrm{O}\right)$ under these reaction conditions. There is no major difference in $\mathrm{G}\left(\mathrm{N}_{2}\right)$ for the reaction in solutions saturated with nitrous oxide or saturated with argon, indicating nitrous oxide is not the source of the nitrogen. The $\mathrm{G}$ value for nitrogen, like the $\mathrm{G}$ value for nitrous oxide, apparently depends on the dose rate and increases with temperature. The close relationship between the results for nitrous oxide and nitrogen suggests that nitrogen also is obtained from the inorganic oxidants rather than from the nitrogen in the organic complexants.

The $\mathrm{G}$ value for ammonia has been reported for the same simulant used in the determination of the $G$ values for nitrous oxide and nitrogen. The results are shown in Figure 4-2. Camaioni et al. (1998) also measured the yields of ammonia during the thermal decomposition and radiolysis of simulants. The yields of ammonia have not been converted into $\mathrm{G}$ values. Ammonia was not observed when the waste containing only nitrogen-free complexants, glycolate, and citrate ion was irradiated. The limited set of measurements suggests that $\mathrm{G}\left(\mathrm{NH}_{3}\right)$ is less than 0.001 and that the ammonia formed during the irradiation arose principally from the nitrogen in the complexants rather than from the nitrogen in the inorganic constituents. Investigations of the thermal reaction of HEDTA, however, indicated more ammonia was formed during the decomposition reaction than could be accounted for by the amount of HEDTA that had reacted (Barefield et al. 1995, 1996). Other work that is discussed subsequently indicates that the decomposition of hydroxylamine produces ammonia, and since the nitrogen atom in this molecule arises from nitrite ion, a portion of the ammonia generated in the waste must originate from the inorganic oxidants.

Barefield et al. $(1995,1996)$ investigated the composition of the gases produced during the thermal decomposition of glycolate ions and HEDTA in a waste simulant at $90^{\circ} \mathrm{C}$ and $120^{\circ} \mathrm{C}$. The results are displayed in Table 4-4 and Figure 4-3.

The observations in Figure 4-3, which are normalized to 100 initial moles of HEDTA, indicate that the yields of the nitrogen-containing gases greatly exceed the yield of hydrogen. As already mentioned, ammonia is a major product of the reaction with HEDTA, and the high yield relative to the amount of HEDTA, ED3A, and EDDA remaining at the end of the reaction strongly implies that a portion of the ammonia must be formed from the inorganic constituents.

In summary, the nitrogen atoms in the complexants are released as ammonia. Additional ammonia arises from the reduction of nitrite ion. The nitrogen atoms in nitrogen and nitrous oxide arise almost exclusively from nitrite ion. No well-defined $G$ values have been determined for the nitrogen gases. Some $\mathrm{G}$ values depend on the dose rate, and others depend on the temperature. These observations are clearly related to the complex nature of the temperature-dependent chemical reactions that simultaneously are responsible for the generation of the nitrogen-containing gases and the oxidation of the organic molecules. 


\section{RPP-6664 REV 0}

Figure 4-2. Ammonia G Values for the Radiation of a Waste Simulant.

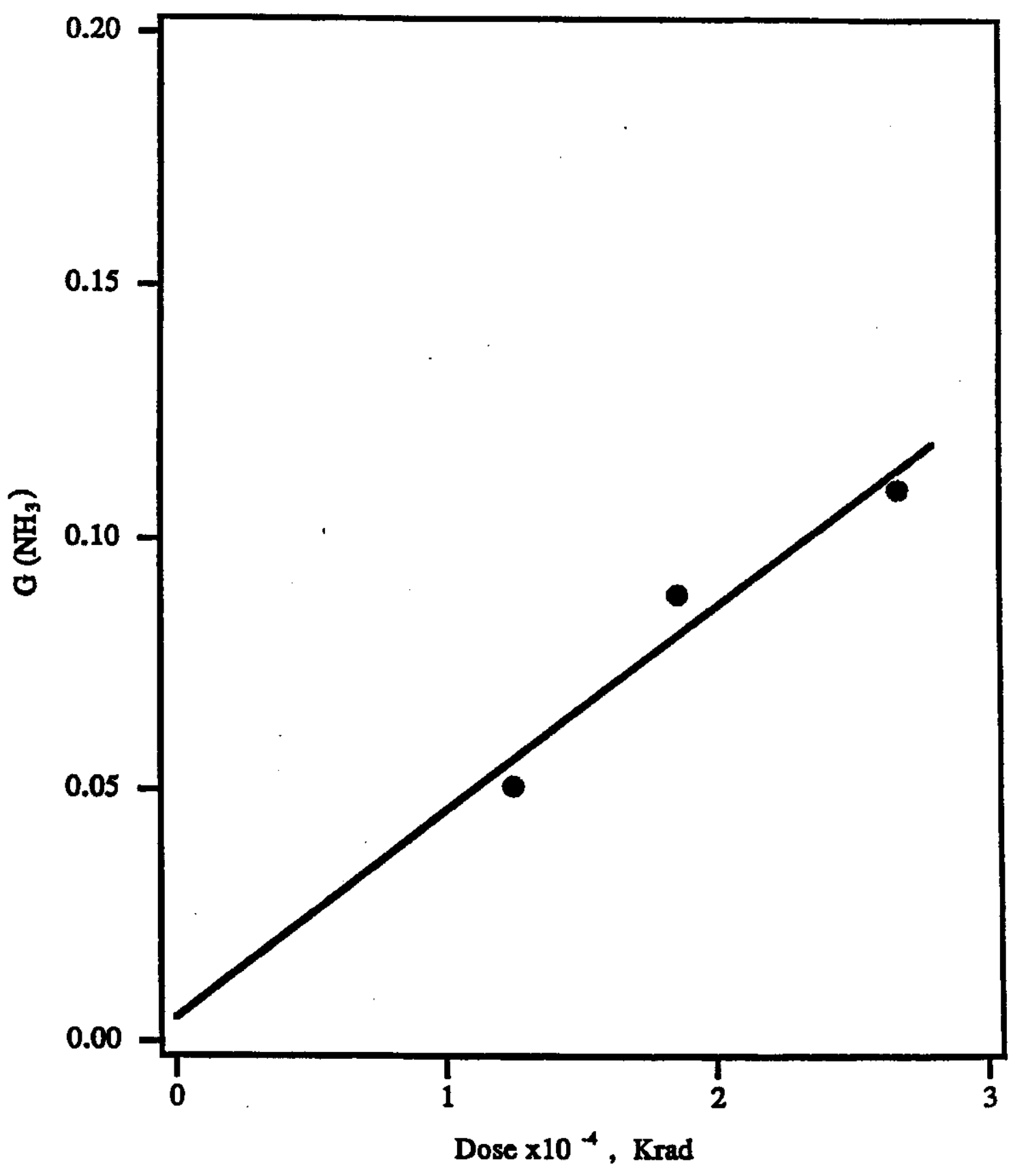




\section{RPP-6664 REV 0}

Table 4-4. Generation of Hydrogen, Nitrogen, and Nitrous Oxide during the Thermal Decomposition of Glycolate in a Simulant.

\begin{tabular}{|c|c|c|}
\hline Gas & $\begin{array}{l}\text { At } 90 \text { C } \\
\text { After } 1,922 \text { Hours } \\
\text { (Moles } 100 \text { Moles Glycolate) }\end{array}$ & $\begin{array}{l}\text { At } 120 \% \mathrm{C} \\
\text { after 1,203 Hours } \\
\text { (Moles/100 Moles Glycolate) }\end{array}$ \\
\hline Hydrogen & 13 & 57 \\
\hline Nitrogen & 24 & 36 \\
\hline Nitrous oxide & 20 & 35 \\
\hline
\end{tabular}

Note: Information in this table is from:

- Barefield, E. K., D. Boatright, A. Desphande, R. Doctorovich, C. L. Liotta, H. M. Neumann, and

S. Seymore, 1995, Mechanisms of Gas Generation from Simulated SY Tank Farm Wastes: FY 1994

Progress Report, PNL-10822, Pacific Northwest Laboratory, Richland, Washington.

Barefield, E. K., D. Boatright, A. Desphande, R. Doctorovich, C. L. Liotta, H. M. Neumann, and S. Seymore, 1996, Mechanisms of Gas Generation from Simulated SY Tank Farm Wastes: FY 1995 Progress Report,

PNL-11247, Pacific Northwest Laboratory, Richland, Washington.

Figure 4-3. Generation of Hydrogen, Nitrogen, Nitrous Oxide, and Ammonia during the Thermal Decomposition of

Hydroxyethylethylenediaminetriacetate

Ion at $90^{\circ} \mathrm{C}$ in a Simulant.

(Barefield et al. 1995, 1996)

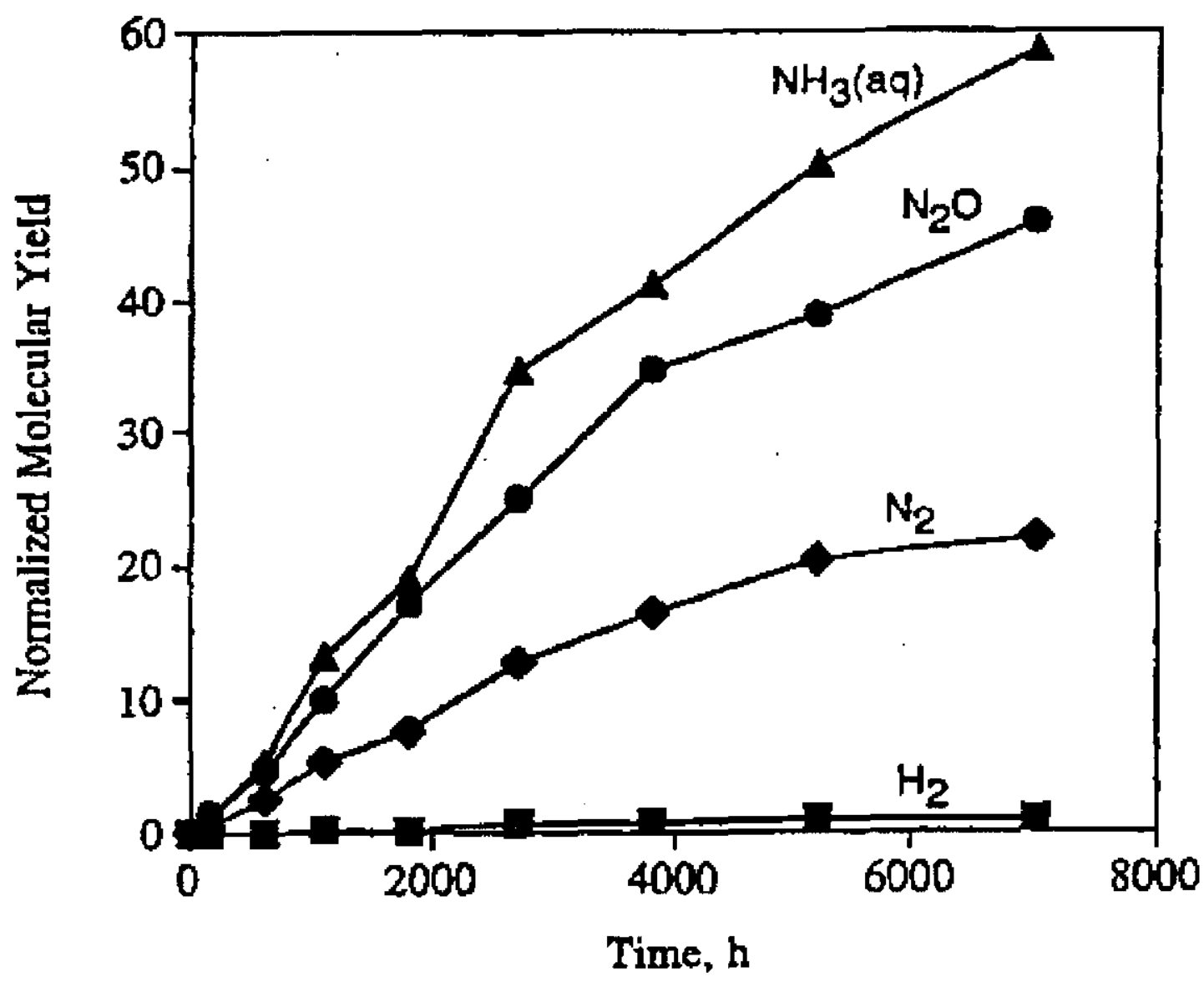




\subsection{LABORATORY INVESTIGATIONS OF WASTE}

Several investigators (Person 1996, 1998; Bryan and Pederson 1995; Pederson and Bryan 1996; Bryan et al. 1996; King et al. 1997; Bryan and King 1998; King and Bryan 1998, 1999) have studied the radiolytic and thermal rates of gas generation in waste samples from different tanks representing different kinds of waste in different configurations. The properties of these waste samples are summarized in Table 4-5, and the results of the investigation of gas formation in the samples are presented in Tables 4-6 and 4-7.

Table 4-5. Average Temperature, Dose Rate, Reactive Carbon Content, and Waste Weight for Selected Waste Tanks.

\begin{tabular}{|c|c|c|c|c|}
\hline Sample & $\begin{array}{l}\text { Temperature } \\
\text { (C) }\end{array}$ & $\begin{array}{l}\text { Dose Rate } \\
\text { (R/h) }\end{array}$ & $\begin{array}{c}\text { Reactive Carbon } \\
\text { (wt\%) }\end{array}$ & $\begin{array}{l}\text { Weight } \\
\text { (kg) }\end{array}$ \\
\hline 241-A-101, Nonconvective layer & 58 & 411 & 0.24 & $2.98 \mathrm{E}+06$ \\
\hline 241-AN-105, Liquid & 41 & 547 & 0.18 & $1.29 \mathrm{E}+06$ \\
\hline 241-AW-101, Convective layer & 37 & 786 & 0.29 & $4.04 \mathrm{E}+06$ \\
\hline $241-S-102$ & 41 & 207 & 0.14 & $3.95 \mathrm{E}+06$ \\
\hline $241-S-106$ & 25 & 177 & 0.10 & $3.09 \mathrm{E}+06$ \\
\hline 241-SY-103, Convective layer & 32 & 443 & 0.74 & $2.05 \mathrm{E}+06$ \\
\hline 241-U-103 & 29 & 449 & 0.60 & $3.02 \mathrm{E}+06$ \\
\hline
\end{tabular}

Note: Information in this table is from

- Person, J. C., 1998, Gas Generation in Tank 241-AN-105 Waste With and Without Oxygen Reactions, HNF-2038, Numatec Hanford Corp. for Fluor Daniel Hanford, In., Richland, Washington.

- King, C. M. and S. A. Bryan, 1999, Thermal and Radiolytic Gas Generation Tests on Material from Tank 241-U-103, 241-AW-101, 241-S-106, and 241-S-102: Status Report, PNNL-12181, Pacific Northwest National Laboratory, Richland, Washington.

Table 4-6. Experimentally Measured Activation Parameters and Generation Efficiency Values for Gas Generation for Selected Waste Samples. (2 sheets)

\begin{tabular}{|c|c|c|c|}
\hline Selected Waste Sample & $\begin{array}{r}\mathbf{E}_{\mathrm{A}} \\
(\mathbf{k J} / \mathbf{m o l}) \\
\end{array}$ & $(\mathrm{mol} / \mathrm{kg} / \mathrm{day})$ & $\begin{array}{l}\text { G Value } \\
\text { (molecules } 100 \mathrm{eV} \text { ) }\end{array}$ \\
\hline \multicolumn{4}{|c|}{ Results for Hydrogen* } \\
\hline 241-A-101, Nonconvective layer & $101(8)$ & 23(3) & $0.0051(0.0004)$ \\
\hline 241-AN-105, Liquid & $87(4)$ & 19(3) & 0.06000 \\
\hline 241-AW-101, Convective layer & $102(3)$ & $25(1)$ & $0.101(0.001)$ \\
\hline $241-S-102$ & $80(19)$ & $15(6)$ & $0.017(0.0004)$ \\
\hline 241-S-106 & $73(6)$ & $12(2)$ & $0.0048(0.0006)$ \\
\hline 241-SY-101, Composite & 94 & 21 & Not measured \\
\hline 241-SY-103 & $91(9)$ & $21(3)$ & 0.14000 \\
\hline 241-U-103 & $91(24)$ & $108(22)$ & 0.00600 \\
\hline
\end{tabular}




\section{RPP-6664 REV 0}

Table 4-6. Experimentally Measured Activation Parameters and Generation Efficiency Values for Gas Generation for Selected Waste Samples. (2 sheets)

\begin{tabular}{|c|c|c|c|}
\hline Selected Waste Sample & $\begin{array}{c}\mathrm{E}_{\mathrm{A}} \\
(\mathrm{kJ} / \mathrm{mol})\end{array}$ & $\begin{array}{l}\ln \mathrm{A} \\
(\mathrm{mol} / \mathrm{kg} / \mathrm{day})\end{array}$ & $\begin{array}{l}\text { G Value } \\
\text { (molecules/100eV) }\end{array}$ \\
\hline \multicolumn{4}{|c|}{ Results for Nitrous Oxide* } \\
\hline 241-A-101, Nonconvective layer & $77(27)$ & 13(9) & $0.0038(0.0004)$ \\
\hline 241-AN-105, Liquid & $107(9)$ & 25 & 0.04 \\
\hline 241-AW-101, Convective layer & $131(20)$ & $33(7)$ & $0.0189(0.0001)$ \\
\hline $241-S-102$ & $87(7)$ & $17(2)$ & $0.009(0.003)$ \\
\hline 241-S-106 & $62(47)$ & $8(16)$ & $0.00013(0.00008)$ \\
\hline 241-SY-101, Composite & 95 & 22 & Not measured \\
\hline 241-SY-103 & $117(9)$ & $29(3)$ & 0.036 \\
\hline 241-U-103 & $108(22)$ & $24(7)$ & $0.019(3)$ \\
\hline \multicolumn{4}{|c|}{ Results for Nitrogen* } \\
\hline 241-A-101, Nonconvective layer & $118(18)$ & $28(6)$ & $0.0020(0.0004)$ \\
\hline 241-AN-105, Liquid & $136(8)$ & 34 & 0.03 \\
\hline 241-AW-101, Convective Layer & $126(15)$ & $31(5)$ & $0.011(0.001)$ \\
\hline $241-S-102$ & $65(39)$ & $9(12)$ & $0.010(0.003)$ \\
\hline 241-S-106 & $95(28)$ & $19(9)$ & $0.0049(0.0004)$ \\
\hline 241-SY-101, Composite & 91 & 22 & Not measured \\
\hline 241-SY-103 & $84(10)$ & $17(3)$ & 0.036 \\
\hline 241-U-103 & $88(34)$ & $18(11)$ & $0.012(3)$ \\
\hline \multicolumn{4}{|c|}{ Results for Methane* } \\
\hline 241-A-101, Nonconvective layer & $125(32)$ & $28(10)$ & $0.00021(0.00004)$ \\
\hline 241-AN-105, Liquid & $141(7)$ & 33 & 0.00080 \\
\hline 241-AW-101, Convective layer & $138(6)$ & $33(2)$ & $0.00106(0.0002)$ \\
\hline $241-S-102$ & $127(33)$ & $29(11)$ & $0.0005(0.0002)$ \\
\hline $241-S-106$ & $104(8)$ & $21(3)$ & $0.00031(0.00003)$ \\
\hline 241-SY-101, Composite & 145 & 136 & Not measured \\
\hline 241-SY-103 & $146(18)$ & $34(6)$ & 0.03600 \\
\hline 241-U-103 & $156(8)$ & $40(3)$ & $0.0022(3)$ \\
\hline
\end{tabular}

Note: Information in this table is from

- Person, J. C., 1998, Gas Generation in Tank 241-AN-105 Waste With and Without Oxygen Reactions, HNF-2038, Numatec Hanford Corporation. Richland, Washington.

- King, C. M., and S. A. Bryan, 1999, Thermal and Radiolytic Gas Generation Tests on Material from Tank 24I-U-103, 24I-AW-J01, 24I-S-106, and 24I-S-102: Status Report, PNNL-12181, Pacific Northwest National Laboratory, Richland, Washington.

*The uncertainties in parentheses were assessed by Bryan et al. and are discussed in the original reports. Bryan and King (1998), Bryan and Pederson $(1994,1995)$, and Bryan et al. $(1996,1997)$. 
Table 4-7. Experimentally Measured Gas Generation Rates for Selected Waste Samples.

\begin{tabular}{|c|c|c|c|}
\hline Sample, & $\begin{array}{l}\text { Total Rate } \\
\text { (molday) }\end{array}$ & $\begin{array}{l}\text { Radiolytic Rate } \\
\text { (mol/kg/day) }\end{array}$ & $\begin{array}{l}\text { Thermal Rate } \\
\text { (mol/kg/day) }\end{array}$ \\
\hline \multicolumn{4}{|c|}{ Results for Hydrogen } \\
\hline 241-A-101, Nonconvective layer & 1.13 & $5.1 \mathrm{E}-8$ & 3.3E-7 \\
\hline 241-AN-105, Liquid & 13.00 & $8.8 \mathrm{E}-07$ & $6.9 \mathrm{E}-7$ \\
\hline 241-AW-101, Convective layer & 10.00 & $2.0 \mathrm{E}-6$ & $4.9 \mathrm{E}-7$ \\
\hline $241-S-102$ & 1.00 & $1.6 \mathrm{E}-7$ & $8.6 \mathrm{E}-8$ \\
\hline $241-S-106$ & 0.19 & $2.1 \mathrm{E}-8$ & $3.9 \mathrm{E}-8$ \\
\hline 241-SY-103 & 3.80 & $1.5 \mathrm{E}-6$ & $3.0 \mathrm{E}-7$ \\
\hline $241-\mathrm{U}-103$ & 0.48 & $7.1 \mathrm{E}-8$ & 8.7E-8 \\
\hline \multicolumn{4}{|c|}{ Results for Nitrous Oxide } \\
\hline 241-A-101, Nonconvective layer & 0.73 & $3.8 \mathrm{E}-8$ & $2.1 \mathrm{E}-7$ \\
\hline 241-AN-105, Liquid & 5.70 & $5.7 \mathrm{E}-7$ & $1.27 \mathrm{E}-7$ \\
\hline 241-AW-101, Convective layer & 1.60 & $3.7 \mathrm{E}-7$ & $3.0 \mathrm{E}-7$ \\
\hline $241-S-102$ & 0.40 & $5.0 \mathrm{E}-8$ & $4.0 \mathrm{E}-8$ \\
\hline $241-S-106$ & 0.20 & $5.7 \mathrm{E}-10$ & $6.3 \mathrm{E}-8$ \\
\hline $241-S Y-103$ & 0.90 & $3.6 \mathrm{E}-7$ & $6.0 \mathrm{E}-8$ \\
\hline $241-\mathrm{U}-103$ & 0.65 & $2.1 \mathrm{E}-7$ & $8.4 \mathrm{E}-9$ \\
\hline \multicolumn{4}{|c|}{ Results for Nitrogen } \\
\hline 241-A-101, Nonconvective layer & 0.59 & $2.0 \mathrm{E}-8$ & $1.8 \mathrm{E}-7$ \\
\hline 241-AN-105, Liquid & 3.50 & $4.0 \mathrm{E}-7$ & $1.8 \mathrm{E}-8$ \\
\hline 241-AW-101, Convective layer & 1.00 & $2.1 \mathrm{E}-7$ & $2.7 \mathrm{E}-8$ \\
\hline $241-S-102$ & 0.20 & $5.0 \mathrm{E}-8$ & $6.0 \mathrm{E}-9$ \\
\hline $241-S-106$ & 0.08 & $2.2 \mathrm{E}-8$ & $4.9 \mathrm{E}-9$ \\
\hline 241-SY-103 & 2.00 & $1.2 \mathrm{E}-7$ & $7.0 \mathrm{E}-7$ \\
\hline $241-\mathrm{U}-103$ & 0.60 & $1.4 \mathrm{E}-7$ & $6.0 \mathrm{E}-8$ \\
\hline \multicolumn{4}{|c|}{ Results for Methane } \\
\hline 241-A-101, Nonconvective layer & 0.06 & $2.1 \mathrm{E}-9$ & $1.7 \mathrm{E}-8$ \\
\hline 241-AN-105, Liquid & 0.0009 & $1.0 \mathrm{E}-8$ & $1.0 \mathrm{E}-9$ \\
\hline 241-AW-101, Convective layer & 0.09 & $2.1 \mathrm{E}-8$ & $2.2 \mathrm{E}-9$ \\
\hline $241-S-102$ & 0.019 & $2.7 \mathrm{E}-9$ & $2.2 \mathrm{E}-9$ \\
\hline $241-S-106$ & 0.007 & $1.4 \mathrm{E}-9$ & $8.5 \mathrm{E}-10$ \\
\hline $241-S Y-103$ & 0.08 & $3.0 \mathrm{E}-8$ & $4.0 \mathrm{E}-11$ \\
\hline 241-U-103 & 0.07 & $2.4 \mathrm{E}-8$ & 1.6E-10 \\
\hline
\end{tabular}

Note: Information in this table is from

- King C. M., and S. A. Bryan, 1999, Thermal and Radiolytic Gas Generation Tests on Material from Tank 241-U-103, 241-AW-101, 241-S-106, and 241-S-102: Status Report, PNNL-12181, Pacific Northwest National Laboratory, Richland, Washington. 
The kinetic observations for the thermal generation of hydrogen, nitrous oxide, nitrogen, and methane show that generation of these gases is temperature dependent, and the rate data for these gases are described by an Arrhenius ${ }^{2}$ relationship:

$$
\text { Rate }=A \times \exp \left(-E_{A}(\text { thermal }) / R T\right)
$$

where "Rate" is the observed rate of formation of gas in moles/kg-day, " $E_{A}($ thermal)" is the activation energy for the thermal reaction in $\mathrm{kJ} / \mathrm{mol}$, " $\mathrm{R}$ " is the gas constant, and " $\mathrm{T}$ " is the temperature in degrees Kelvin.

The observed thermal activation energies for hydrogen formation range from $73 \mathrm{~kJ} / \mathrm{mol}$ to $101 \mathrm{~kJ} / \mathrm{mol}$ with an average of $89 \mathrm{~kJ} / \mathrm{mol}$. The values for nitrous oxide and nitrogen are comparable, with ranges from $77 \mathrm{~kJ} / \mathrm{mol}$ to $131 \mathrm{~kJ} / \mathrm{mol}$ and $65 \mathrm{~kJ} / \mathrm{mol}$ to $126 \mathrm{~kJ} / \mathrm{mol}$, respectively. The activation energies for the three gases reflect the observation that the proportions of the different gases change in an inconsistent manner when the temperature changes. The activation energy for methane formation is significantly larger than the activation energies for the formation of the other gases, with a range from $125 \mathrm{~kJ} / \mathrm{mol}$ to $156 \mathrm{~kJ} / \mathrm{mol}$.

When gas generation is dominated by thermal processes, it is difficult to determine experimentally whether the radiolytic generation rate is or is not temperature dependent. Laboratory work indicates that radiolytic hydrogen generation in tank 241-SY-103 is not temperature dependent, but hydrogen generation rates for waste samples from tanks 241-A-101, 241-AW-101, 241-S-106, and 241-U-103 depend on the reaction temperature (Pederson and Bryan 1996; King and Bryan 1998, 1999). The observed activation energies for hydrogen formation are shown in Table 4-8.

Table 4-8. Arrhenius Parameters for Hydrogen Formation During Radiolysis.

\begin{tabular}{|l|c|c|}
\hline \multirow{2}{*}{$\begin{array}{c}\text { Sample } \\
\text { 241-A-101, Nonconvective Layer }\end{array}$} & $\begin{array}{c}\mathbf{E}_{\mathbf{A}}(\mathbf{R a d}) \\
(\mathbf{k J} / \mathbf{m o l})\end{array}$ & $\begin{array}{c}\text { Uncertainty } \\
\mathbf{k} / \mathbf{m o l})\end{array}$ \\
\hline $241-\mathrm{AW}-101$, Convective layer & 51 & 2 \\
\hline $241-\mathrm{S}-102$ & 39 & 7 \\
\hline $241-\mathrm{S}-106$ & 48 & 3 \\
\hline $241-\mathrm{U}-103$ & 60 & 2 \\
\hline
\end{tabular}

The investigations of tank waste parallel the results obtained in work with simulants. Meisel et al. (1993) observed that the $\mathrm{G}$ values for hydrogen generation were temperature dependent for all complexants except sodium citrate, and Camaioni et al. (1996b) reported similar observations for another simulant. The activation energies ranged from $4 \mathrm{~kJ} / \mathrm{mol}$ to $39 \mathrm{~kJ} / \mathrm{mol}$.

\footnotetext{
${ }^{2}$ The Arrhenius equation is customarily expressed by using the observed rate constant for the process rather than the by using the observed rate of the process, but it is not possible to define a conventional rate constant for the complex wastes. The use of rate data yields the same activation energy as would be obtained by the use of the rate constant, but the magnitude and units of the related " $\mathrm{A}$ " values differ importantly.
} 


\section{RPP-6664 REV 0}

The chemical models presented elsewhere in this report account for the temperature dependence of the radiolytic reaction. This process is initiated by the temperature-independent radiolysis of the aqueous solution of sodium nitrite and sodium nitrate. The reagents formed in that reaction convert the organic molecules into other intermediate compounds that subsequently decompose to form the gases. The chemical reactions responsible for the formation and decomposition of the organic intermediates are complex, temperature-dependent processes, including the multistep formation of hydrogen from formaldehyde and the formation of nitrous oxide from hydroxylamine. The chemical models also account for the larger activation energy of the thermal reactions. These processes are necessarily initiated by chemical reactions with high activation energies such as the formation of nitric oxide and nitrogen dioxide from the inorganic constituents.

\subsection{CHEMICAL PATHWAYS TO GASEOUS PRODUCTS}

General features of the oxidation-reduction cascade are discussed in Section 4.5.1. A chemical model describing the reaction pathways by which hydrogen and the nitrogen-containing gases are produced is discussed in Sections 4.5.2 and 4.5.3. The chemistry of methane formation is examined in Section 4.5.4 and the role of oxygen in this chemistry is considered in Section 4.5.5.

\subsubsection{The Oxidation-Reduction Cascade}

As the complexants and solvents are oxidized below the surface of the waste in the absence of oxygen (air), the nitrite ion is reduced to ammonia, nitrous oxide, and nitrogen. Hydrogen is a byproduct of the oxidation-reduction reactions between the organic complexants and nitrite ions. This feature has been demonstrated in several ways. For example, the hydrogen to (nitrogen + nitrous oxide) mole ratios are less than one for the thermal decomposition of complexants in simulants and for the retained gases (Ashby et al. 1994; Barefield et al. 1995, 1996; Camaioni et al. 1997; Shekarriz et al. 1997, Mahoney et al. 1999). Other laboratory work also points to the selective formation of nitrogen-containing gases. Hydroxylamine, an important intermediate responsible for gas formation decomposes rapidly to produce nitrogen, nitrous oxide, and ammonia but provides no hydrogen (Barefield et al. 1995, 1996).

The stoichiometry of the reactions provides insight concerning this feature of the chemistry (Person 1996, 1998). Six electrons are produced during the oxidation of sodium glycolate to sodium carbonate in an alkaline solution:

$$
9 \mathrm{NaOH}+\mathrm{HOCH}_{2} \mathrm{CO}_{2} \mathrm{Na} \rightarrow 2 \mathrm{Na}_{2} \mathrm{CO}_{3}+6 \mathrm{H}_{2} \mathrm{O}+6 \mathrm{Na}^{+}+6 \mathrm{e}^{-}
$$

The related reduction reactions for the conversion of water to hydrogen and for the conversion of nitrogen dioxide to nitrous oxide, ammonia, and nitrogen are shown in the next set of equations.

$$
\begin{gathered}
2 \mathrm{e}^{-}+2 \mathrm{Na}^{+}+2 \mathrm{H}_{2} \mathrm{O} \rightarrow \mathrm{H}_{2}+2 \mathrm{NaOH} \\
6 \mathrm{e}^{-}+6 \mathrm{Na}^{+}+3 \mathrm{H}_{2} \mathrm{O}+2 \mathrm{NO}_{2} \rightarrow \mathrm{N}_{2} \mathrm{O}+6 \mathrm{NaOH}
\end{gathered}
$$




\section{RPP-6664 REV 0}

$$
\begin{aligned}
& 7 \mathrm{e}^{-}+7 \mathrm{Na}^{+}+5 \mathrm{H}_{2} \mathrm{O}+\mathrm{NO}_{2} \rightarrow \mathrm{NH}_{3}+7 \mathrm{NaOH} \\
& 8 \mathrm{e}^{-}+8 \mathrm{Na}^{+}+4 \mathrm{H}_{2} \mathrm{O}+2 \mathrm{NO}_{2} \rightarrow \mathrm{N}_{2}+8 \mathrm{NaOH}
\end{aligned}
$$

The oxidation of 1 mole of sodium glycolate is equivalent to the formation of 3 moles of hydrogen, 1 mole of nitrous oxide, and somewhat less than 1 mole of ammonia or nitrogen. Inasmuch as the volumes of nitrogen and nitrous oxide produced during thermal and radiolytic reactions of waste are comparable to or exceed the volume of hydrogen formed in the same waste, it is apparent that the electron transfer reactions of the inorganic nitrogen compounds dominate the chemistry.

\subsubsection{Hydrogen Formation}

4.5.2.1 Hydrogen Atom Abstraction Reaction. Molecular hydrogen can be formed in Hanford Site wastes via reactions in which a hydrogen atom abstracts a second hydrogen atom from an organic compound. Hydrogen atoms are formed initially as a primary product of the radiolysis of water and subsequently by beta scission reactions of intermediate organic radicals. Such radical reactions are initiated by radiolysis at all temperatures. They are also initiated by the radicals formed during the thermal reactions of waste components, through reactions with activation energies near $100 \mathrm{~kJ} / \mathrm{mol}$. However, the yields of hydrogen atoms from the radiolysis of the sodium nitrate- and sodium nitrite-rich Hanford Site wastes are small because hydrogen atoms are very rapidly scavenged in reactions with the inorganic constituents, as shown by the kinetic reaction model shown in Section 2.2 and by empirical expressions of Tabata et al. (1991) and Hu (2000). Consequently, Camaioni et al. (1998) and Meisel et al. (1997, 2000) have concluded that little hydrogen is formed by this reaction path. Rather, they attribute hydrogen gas formation in alkaline aqueous solution to base-catalyzed ionic reactions of formaldehyde and other aldehydes as originally proposed by the group at the Georgia Institute of Technology (Ashby et al. 1993).

However, the formation of molecular hydrogen through hydrogen atom abstraction reactions is probably a relatively more important process for the radiolysis of hydrocarbons and phosphate esters in organic phases. The $\mathrm{G}$ values for the generation of hydrogen from hydrocarbons in hydrocarbons are comparable with the $\mathrm{G}$ values for the disappearance of the hydrocarbons (Spinks and Woods 1990). Although organic oils have separated from the wet wastes in only a few tanks, it is pertinent that hydrogen was generated very rapidly in tank 241-C-106, which contained an organic oil suspended in a layer of sludge before sluicing in 1998 and 1999.

4.5.2.2 Base-Catalyzed Ionic Oxidation Reactions. As discussed previously, formaldehyde is believed to be an important intermediate product of the fragmentation reactions of the complexants. The hydroxide ion-catalyzed transformations of this aldehyde and other aldehydes are the most important sources of hydrogen in Hanford Site wastes. Ashby et al. $(1993,1994)$ and Barefield et al. $(1995,1996)$ described the importance of this variant of the Cannizzaro reaction (Lowry and Richardson 1987; Carey and Sundberg 1990; March 1992) for the production of hydrogen and sodium formate from formaldehyde in waste. The initial work was confirmed by Karpoor et al. (1995). 


\section{RPP-6664 REV 0}

Formaldehyde is readily hydrated in an aqueous solution, and the protons of the hydrate are sufficiently acidic to be removed by the hydroxide ion to form a dianion. The reaction between this anion and water to form hydrogen is the dominant decomposition pathway for formaldehyde in strongly alkaline solutions (Ashby et al. 1993). The rate of the reaction depends on the concentration of hydroxide ion since the reaction proceeds by the removal of the hydridic hydrogen of the dianion of the dihydrate:

$$
\begin{gathered}
\mathrm{H}_{2} \mathrm{CO}+\mathrm{OH}^{-} \rightarrow \mathrm{H}_{2} \mathrm{COH}\left(\mathrm{O}^{-}\right) \\
\mathrm{H}_{2} \mathrm{COH}\left(\mathrm{O}^{-}\right)+\mathrm{OH}^{-} \rightarrow \mathrm{H}_{2} \mathrm{C}\left(\mathrm{O}^{-}\right)_{2}+\mathrm{H}_{2} \mathrm{O} \\
\mathrm{H}_{2} \mathrm{C}\left(\mathrm{O}^{-}\right)_{2}+\mathrm{H}_{2} \mathrm{O} \rightarrow \mathrm{HCO}_{2}^{-}+\mathrm{OH}^{-}+\mathrm{H}_{2}
\end{gathered}
$$

Hydrogen can also be obtained from the glycolate ion through similar chemistry. The radical reactions described in the previous section, either directly through the reaction with hydroxy radical or indirectly through the O-nitro compound, oxidize the radical produced from glycolate ion to the hydrate. This hydrate undergoes the same reactions as formaldehyde and provides hydrogen:

$$
\begin{gathered}
\mathrm{HOCHCO}_{2}^{-}+\mathrm{OH} \rightarrow \mathrm{HOCH}(\mathrm{OH}) \mathrm{CO}_{2}^{-} \\
\mathrm{HOCHCO}_{2}^{-}+\mathrm{NO}_{2} \rightarrow \mathrm{HOCH}(\mathrm{ONO}) \mathrm{CO}_{2}^{-} \\
\mathrm{HOCH}(\mathrm{ONO}) \mathrm{CO}_{2}^{-}+\mathrm{H}_{2} \mathrm{O} \rightarrow \mathrm{HONO}+\mathrm{HOCH}(\mathrm{OH}) \mathrm{CO}_{2}^{-} \\
\mathrm{HOCH}(\mathrm{OH}) \mathrm{CO}_{2}^{-}+\mathrm{OH}^{-} \rightarrow \mathrm{HOCH}\left(\mathrm{O}^{-}\right) \mathrm{CO}_{2}^{-}+\mathrm{H}_{2} \mathrm{O} \\
\mathrm{HOCH}\left(\mathrm{O}^{-}\right) \mathrm{CO}_{2}^{-}+\mathrm{OH}^{-} \rightarrow \mathrm{HC}\left(\mathrm{O}^{-}\right)_{2} \mathrm{CO}_{2}^{-}+\mathrm{H}_{2} \mathrm{O} \\
\mathrm{HC}\left(\mathrm{O}^{-}\right)_{2} \mathrm{CO}_{2}^{-}+\mathrm{H}_{2} \mathrm{O} \rightarrow \mathrm{O}_{2} \mathrm{CCO}_{2}^{-}+\mathrm{OH}^{-}+\mathrm{H}_{2}
\end{gathered}
$$

Reactions of this kind, rather than hydrogen atom abstraction reactions, are primarily responsible for the hydrogen formed from organic complexants in aqueous solution.

\subsubsection{Formation of Nitrogen-Containing Gases}

The reaction cascades discussed in Section 4.5.1 result in the reduction of the nitrite ion to form reactive inorganic intermediates including the nitrosyl anion and hydroxylamine. These intermediates are responsible for the eventual formation of nitrous oxide, nitrogen, and a portion of the ammonia. For example, the ionic aluminate ion-catalyzed decomposition of HEDTA,

$$
\begin{gathered}
\left(\mathrm{O}_{2} \mathrm{CCH}_{2}\right)_{2} \mathrm{NCH}_{2} \mathrm{CH}_{2} \mathrm{~N}\left(\mathrm{CH}_{2} \mathrm{CO}_{2}\right) \mathrm{CH}_{2} \mathrm{CH}_{2} \mathrm{OAl}^{-}(\mathrm{OH})_{2}(\mathrm{ONO})+\mathrm{H}_{2} \mathrm{O} \\
\left(\mathrm{O}_{2} \mathrm{CCH}_{2}\right)_{2} \mathrm{NCH}_{2} \mathrm{CH}_{2} \mathrm{~N}\left(\mathrm{CH}_{2} \mathrm{CO}_{2}^{-}\right) \mathrm{CH}_{2} \mathrm{CHO}+\mathrm{Al}(\mathrm{OH})_{4}^{-}+\mathrm{NOH}
\end{gathered}
$$

the base-catalyzed decomposition of the C-nitro compounds,

$$
\begin{gathered}
\mathrm{HOCH}_{2} \mathrm{NO}_{2}+\mathrm{OH}^{-} \rightarrow \mathrm{HOCH}\left(\mathrm{NO}_{2}{ }^{-}\right)+\mathrm{H}_{2} \mathrm{O} \\
\mathrm{HOCH}\left(\mathrm{NO}_{2}{ }^{-}\right)+\mathrm{OH}^{-} \rightarrow \mathrm{HCO}_{2}^{-}+\mathrm{NO}^{-}+\mathrm{H}_{2} \mathrm{O}
\end{gathered}
$$




\section{RPP-6664 REV 0}

and the base-catalyzed decomposition of hydroxylamine provide either nitrosyl anion or the protonated neutral molecule.

The oximes produced following the nitrosation of the glycolate, glycinate, and the other complexants and solvents hydrolyze to give hydroxylamine or its anion as one of the products:

$$
\begin{gathered}
\mathrm{HOC}(=\mathrm{NOH}) \mathrm{CO}_{2}^{-}+\mathrm{OH}^{-} \rightarrow \mathrm{O}_{2} \mathrm{CCO}_{2}^{-}+\mathrm{NH}_{2} \mathrm{OH} \\
\mathrm{H}_{2} \mathrm{NC}(=\mathrm{NOH}) \mathrm{CO}_{2}^{-}+\mathrm{H}_{2} \mathrm{O} \rightarrow \mathrm{H}_{2} \mathrm{NC}(=\mathrm{O}) \mathrm{CO}_{2}^{-}+\mathrm{NH}_{2} \mathrm{OH} \\
\mathrm{RCH}=\mathrm{NOH}+\mathrm{H}_{2} \mathrm{O} \rightarrow \mathrm{RCHO}+\mathrm{NH}_{2} \mathrm{OH}
\end{gathered}
$$

The chemistry of these intermediates and the reaction pathways for gas formation are examined in the following sections. The presence of oxygen can alter these reaction pathways to favor the formation of hydrogen and suppress the formation of nitrogenous gases, as discussed in Section 4.5.5.

4.5.3.1 Pathways to Nitrous Oxide from the Nitrosyl Anion. The nitrosyl anion is isoelectronic with oxygen and has a triplet ground state and novel chemical properties (Meisel et al. 1991a, 1991b, 1993; Janaway et al. 1997). The substance readily dimerizes to form the hyponitrite dianion, which exists in solution in equilibrium with the acid forms (Cotton and Wilkinson 1988; Barefield et al. 1995).

$$
\begin{gathered}
2 \mathrm{NO}^{-} \rightarrow{ }^{-} \mathrm{ONNO}^{-} \\
\mathrm{ONNO}^{-}+\mathrm{H}_{2} \mathrm{O} \rightarrow{ }^{-} \mathrm{ONNOH}+\mathrm{HO}^{-} \\
{ }^{-} \mathrm{ONNOH}+\mathrm{H}_{2} \mathrm{O} \rightarrow \mathrm{HONNOH}^{-} \mathrm{HO}^{-}
\end{gathered}
$$

Investigations of this substance (Buchholz and Powell 1963; Hughes and Stedman 1963) indicate that it decomposes in $2.0 \mathrm{M}$ sodium hydroxide solution at $60^{\circ} \mathrm{C}$ with a 4-hour half life (Barefield et al. 1995) to form nitrous oxide:

$$
{ }^{-} \mathrm{ONNOH} \rightarrow \mathrm{N}_{2} \mathrm{O}+\mathrm{HO}^{-}
$$

The nitrosyl anion also combines with the nitrite ion to produce the related hyponitrate dianion, which also equilibrates with the acid forms (Cotton and Wilkinson 1988):

$$
\begin{gathered}
\mathrm{NO}^{-}+\mathrm{NO}_{2}^{-} \rightarrow \mathrm{ONNO}^{-} \\
\mathrm{ONNO}_{2}^{-}+\mathrm{H}_{2} \mathrm{O} \rightarrow \mathrm{HONNO}_{2}^{-}+\mathrm{HO}^{-} \\
\mathrm{HONNO}_{2}^{-}+\mathrm{H}_{2} \mathrm{O} \rightarrow \mathrm{HONNO}_{2} \mathrm{H}+\mathrm{HO}^{-}
\end{gathered}
$$

The hyponitrates are more stable than the hyponitrites (Bonner and Ravid 1975; Hughes and Wimbeldon 1966) and have a half life of about 380 hours in $2.0 \mathrm{M}$ sodium hydroxide at $60^{\circ} \mathrm{C}$ (Barefield et al. 1995). Decomposition in alkaline solution apparently occurs by dissociation to nitrite ion and nitrosyl anion:

$$
{ }^{-} \mathrm{NNO}_{2}^{-} \rightarrow \mathrm{NO}^{-}+\mathrm{NO}_{2}^{-}
$$




\title{
RPP-6664 REV 0
}

The nitrosyl anion either recombines with the nitrite ion to reform the original dianion or with another nitrosyl anion to produce the hyponitrite ion, which decomposes to nitrous oxide.

4.5.3.2 Pathways to Nitrous Oxide, Nitrogen, and Ammonia from Hydroxylamine. Hydroxylamine, which is obtained by the hydrolysis of oximes and hydroximates, appears to be a key intermediate in the generation of gases from Hanford Site wastes. Once formed, the compound relatively rapidly decomposes in catalyzed and uncatalyzed reactions to form nitrogen, ammonia, and nitrous oxide (Meisel et al. 1993, Barefield et al. 1995, 1996). Hydrogen is not usually formed in the reactions of hydroxylamine (Barefield et al. 1996).

Hydroxylamine is formed from the complexants and solvents in the wastes in several different ways. The underlying chemistry, which was outlined in Section 3.3, postulates that nitroso compounds are produced by radical recombination reactions, as shown for one of the radicals produced by ED3A:

\section{$\mathrm{R}_{2} \mathrm{NCH}_{2} \mathrm{CH}_{2} \mathrm{~N}\left(\mathrm{CH}_{2} \mathrm{CO}_{2}^{-}\right)\left(\mathrm{CHCO}_{2}{ }^{-}\right)+\mathrm{NO} \rightarrow$ $\mathrm{R}_{2} \mathrm{NCH}_{2} \mathrm{CH}_{2} \mathrm{~N}\left(\mathrm{CH}_{2} \mathrm{CO}_{2}^{-}\right)\left(\mathrm{CH}(\mathrm{NO}) \mathrm{CO}_{2}{ }^{-}\right)$}

Such substances isomerize into oximes and subsequently undergo hydrolysis to form a carbonyl compound and hydroxylamine:

\author{
$\mathrm{R}_{2} \mathrm{NCH}_{2} \mathrm{CH}_{2} \mathrm{~N}\left(\mathrm{CH}_{2} \mathrm{CO}_{2}^{-}\right)\left(\mathrm{CH}(\mathrm{NO}) \mathrm{CO}_{2}{ }^{-}\right) \rightarrow$ \\ $\mathrm{R}_{2} \mathrm{NCH}_{2} \mathrm{CH}_{2} \mathrm{~N}\left(\mathrm{CH}_{2} \mathrm{CO}_{2}^{-}\right)\left(\mathrm{C}(=\mathrm{NOH}) \mathrm{CO}_{2}{ }^{-}\right)$ \\ $\mathrm{R}_{2} \mathrm{NCH}_{2} \mathrm{CH}_{2} \mathrm{~N}\left(\mathrm{CH}_{2} \mathrm{CO}_{2}^{-}\right)\left(\mathrm{C}(=\mathrm{NOH}) \mathrm{CO}_{2}{ }^{-}\right)+\mathrm{H}_{2} \mathrm{O} \rightarrow$ \\ $\mathrm{R}_{2} \mathrm{NCH}_{2} \mathrm{CH}_{2} \mathrm{~N}\left(\mathrm{CH}_{2} \mathrm{CO}_{2}{ }^{-}\right)\left(\mathrm{COCO}_{2}^{-}\right)+\mathrm{H}_{2} \mathrm{NOH}$
}

The nitrogen atom (shown in bold) from nitric oxide, which originates from the nitrite ion, is converted into the reduced nitrogen atom in hydroxylamine. The organic hydrogen atom (shown in bold) in the original complexant eventually appears as a hydroxylic hydrogen atom in hydroxylamine or in water. This oxidation reaction sequence circumvents the conversion of an organic hydrogen atom into molecular hydrogen.

The decomposition of hydroxylamine proceeds readily in waste simulants to give nitrous oxide, nitrogen, and ammonia (Meisel et al. 1993). Other laboratory work indicates that hydroxylamine is not stable in alkaline solutions, and many cations accelerate its decomposition (Van Der Puy 1985; Van Der Puy and Dimmit 1985). Lunak and Veprek-Siska (1974) determined the order of catalytic reactivity for the common cations:

$$
\mathrm{Fe}(\text { II })>\mathrm{Ni}(\mathrm{II})>\mathrm{Cu}(\mathrm{II})>\mathrm{Co}(\mathrm{II})>\mathrm{Ag}(\mathrm{II})>\mathrm{Zn} \text { (II) }
$$

When pure hydroxylamine is dissolved in pure water containing $1 M$ reagent-grade sodium hydroxide, the compound is converted into ammonia and nitrogen with only small amounts of nitrous oxide, but no hydrogen, in 30 hours (Barefield et al. 1995, 1996). Under other conditions, the reaction proceeds more rapidly, and considerably more nitrous oxide is formed (Bonner et al. 1978). Apparently, nitrosyl anion is produced, and it has several different decomposition pathways, as discussed in Section 4.5.3.1. 


\section{RPP-6664 REV 0}

The reaction pathways by which hydroxylamine decomposes have not been definitely established. Barefield et al. (1996) have tentatively proposed that the reactions of hydroxylamine in an alkaline solution proceed via a novel pair of intermediates, nitrene and the nitrosyl anion, both of which they propose are formed from hydroxylamine in the presence of the hydroxide ion. The initial acid-base equilibria and nitrene formation are shown in the next equations:

$$
\begin{gathered}
\mathrm{HONH}_{2}+\mathrm{OH}^{-} \rightarrow \mathrm{H}_{2} \mathrm{NO}^{-}+\mathrm{HOH} \\
\mathrm{HONH}_{2}+\mathrm{OH}^{-} \rightarrow \mathrm{HONH}^{-}+\mathrm{HOH} \\
\mathrm{HONH}^{-} \rightarrow \mathrm{NH}+\mathrm{OH}^{-}
\end{gathered}
$$

Barefield et al. (1996) also propose that the nitrene abstracts a hydride ion from the hydroxylamine anion to produce the amide anion, which instantly protonates to form ammonia and HNO, which according to this formulation reacts with the anion of hydroxylamine to produce an adduct that dehydrates to give nitrogen:

$$
\begin{gathered}
\mathrm{NH}+\mathrm{H}_{2} \mathrm{NO}^{-} \rightarrow \mathrm{H}_{2} \mathrm{~N}^{-}+\mathrm{HNO} \\
\mathrm{H}_{2} \mathrm{~N}^{-}+\mathrm{HOH} \rightarrow \mathrm{NH}_{3}+\mathrm{OH}^{-} \\
\mathrm{H}_{2} \mathrm{NO}^{-}+\mathrm{NO}^{-} \rightarrow \mathrm{H}_{2} \mathrm{~N}^{-}\left(\mathrm{O}^{-}\right) \mathrm{NO}^{-} \rightarrow \mathrm{N}_{2}+2 \mathrm{OH}^{-}
\end{gathered}
$$

This formulation accounts for the two principal products, ammonia and nitrogen, observed in the work with pure compounds. It also accounts for the fact that nitrous oxide is obtained only in the later stages of the reaction with pure compounds and in the complex waste mixtures. In the early stages of the reaction, nitrosyl anion is scavenged by the reaction with the anion of hydroxylamine, but as the concentration of the starting material is depleted, dimerization becomes competitive and nitrous oxide is formed. This is one of several branch points in which the product distribution is dictated by the differences in the concentrations of the reagents and in the rate constants for competing bimolecular reactions.

Nast and Foppl (1948) and Barefield et al. (1996) indicate that the stoichiometry of the reaction for the formation of hyponitrite from hydroxylamine in basic solution is shown below:

$$
4 \mathrm{NH}_{2} \mathrm{OH}+2 \mathrm{OH}^{-} \rightarrow 2 \mathrm{NH}_{3}+\mathrm{N}_{2} \mathrm{O}_{2}{ }^{2-}+4 \mathrm{H}_{2} \mathrm{O}
$$

The half-life of $\mathrm{N}_{2} \mathrm{O}_{2}{ }^{2-}$ was calculated from information in the chemical literature by Ashby et al. (1994) to be 600 hours at $25^{\circ} \mathrm{C}$ in $1 M \mathrm{NaOH}$. Since the $\mathrm{N}_{2} \mathrm{O}_{2}{ }^{2-}$ anion decomposes predominantly to yield nitrous oxide, the ratio of nitrogen to nitrous oxide formed from the decomposition of hydroxylamine in alkaline solutions decreased with increased reaction time (Barefield et al. 1996).

The chemistry in the waste is much more complex because other substances compete for these reactive intermediates, but the suggestion that nitrene is a reactive intermediate capable of hydride abstraction provides a possible explanation, in the absence of other plausible alternatives, for the formation of ammonia from hydroxylamine. Nitrosyl anion and its conjugate acid appear to be very important initial products of the reduction of the nitrite ion. 


\section{RPP-6664 REV 0}

Only a few specific alternatives have been proposed for the formation of nitrogen from hydroxylamine in alkaline solutions. Van Der Puy and Dimmit (1985) have suggested that metal ions oxidize hydroxylamine and produce a radical, $\mathrm{H}_{2} \mathrm{NO}$, that dimerizes:

$$
\begin{gathered}
\mathrm{H}_{2} \mathrm{NOH}+\mathrm{M}^{\mathrm{n}+} \rightarrow \mathrm{H}_{2} \mathrm{NO}+\mathrm{M}^{(\mathrm{n}-1)+}+\mathrm{H}^{+} \\
2 \mathrm{H}_{2} \mathrm{NO} \rightarrow \mathrm{NH}(\mathrm{OH}) \mathrm{NH}(\mathrm{OH}) \\
\mathrm{NH}(\mathrm{OH}) \mathrm{NH}(\mathrm{OH}) \rightarrow \mathrm{N}_{2}+\mathrm{H}_{2} \mathrm{O}
\end{gathered}
$$

While specific investigations of this reaction pathway have not been undertaken, the oxidationreduction reactions of nitrogen-containing ligands coordinated to transition metals has received considerable attention. It is very well established that nitrogen oxide fragments coordinate to transition metals (Cotton and Wilkinson 1988); that the compounds with coordinated nitrosyl ligands are in acid-base equilibrium with corresponding compounds with coordinated nitro ligands (Assefa and Stanbury 1997; MacNeil et al. 1997); and that oxidation-reduction reactions proceed relatively readily. For example, the nitrosyl group in the ruthenium bipyridine (bpy) complex is oxidized to a nitro group:

$$
\text { cis- }\left[\mathrm{Ru}(\text { bpy })_{2}\left(\mathrm{NH}_{3}\right) \mathrm{NO}\right]^{3+}+\mathrm{H}_{2} \mathrm{O} \rightarrow \text { cis- }\left[\mathrm{Ru}(\mathrm{bpy})_{2}\left(\mathrm{NH}_{3}\right) \mathrm{NO}_{2}\right]^{+}+2 \mathrm{H}^{+}
$$

Coordinated ammonia molecules in other complexes have been oxidized to coordinated nitrosyl in aqueous solution (Assefa and Stanbury 1997). Further, dinitrogen formation was observed in the reactions of molecules with coordinated nitrosyl ligands. Thus, transition metal coordination complexes can accelerate the rates of conversion of nitrogen oxide considerably over rates that could be achieved in homogeneous solution in the absence of these reagents. Since the Hanford Site wastes are known to contain iron, chromium, nickel, and traces of many other potentially catalytic transition metal ions, these reaction pathways may also contribute to the formation of the nitrogenous gases. However, Van Der Puy and Dimmit (1985) have pointed out that the reactions occur readily even in the absence of complex ligands.

4.5.3.3 Ammonia from Organic Sources. Hanford Site tank wastes originally contained large quantities of both EDTA and HEDTA (Webb et al. 1995). The characterization work discussed in Section 2.2 has shown that these two nitrogen-containing complexants have been substantially converted into other nitrogen-containing compounds, including ED3A, NTA, and IDA, or completely degraded to oxalate, formate, and carbonate ions during the years of storage. The chemical reaction pathways for the formation of these compounds and other intermediate oxidation products were discussed in Section 2.2. These molecules are systematically oxidized and fragmented until the tertiary nitrogen atom in the original complexant is converted into a primary nitrogen atom in an intermediate such as u-EDTA or glycine. The nitrogen atoms in the substances with primary amino groups can be rather directly converted into ammonia by additional oxidative reactions that produce an amide, nitrile, or cyanate.

$\begin{array}{llllll}\text { EDTA } \rightarrow & \text { NTA } \rightarrow & \text { IDA } \rightarrow & \text { Glycinate } & \rightarrow & \text { Ammonia } \\ \text { Tertiary } & \text { Tertiary } & \text { Secondary } & \text { Primary } & & \\ \text { Amine } & \text { Amine } & \text { Amine } & \text { Amine } & & \end{array}$




\section{RPP-6664 REV 0}

4.5.3.3.1 Ammonia from Amides. One pathway for ammonia production is through a primary amide. As already discussed, HEDTA and EDTA are oxidized in a step-wise manner that eventually converts the original tertiary amines into primary amines. The exact pathway by which these processes occur has not been established. However, a two-step process, in which a methylene group of the original complex is oxidized to a carbonyl group to form an amide and the amide is then hydrolyzed to fragment the molecule, provides a reasonable chemical explanation. In this reaction sequence, the tertiary amino group is converted into a secondary amino group and then into a primary amino group. These initial products undergo the same reactions and eventually provide ammonia. The initial oxidation reactions are illustrated in the following equations for three different methylene groups of HEDTA and two different methylene groups in ED3A where " $\mathrm{R}$ " is used in these equations to represent the other carboxymethyl groups, $\mathrm{CH}_{2} \mathrm{CO}_{2}{ }^{-}$:

$$
\begin{aligned}
\mathrm{R}_{2} \mathrm{NCH}_{2} \mathrm{CH}_{2} \mathrm{~N}\left(\mathrm{CH}_{2} \mathrm{CO}_{2}{ }^{-}\right) \mathrm{CH}_{2} \mathrm{CH}_{2} \mathrm{OH} & \rightarrow \mathrm{R}_{2} \mathrm{NCH}_{2} \mathrm{CON}\left(\mathrm{CH}_{2} \mathrm{CO}_{2}{ }^{-}\right) \mathrm{CH}_{2} \mathrm{CH}_{2} \mathrm{OH} \\
\mathrm{R}_{2} \mathrm{NCH}_{2} \mathrm{CH}_{2} \mathrm{~N}\left(\mathrm{CH}_{2} \mathrm{CO}_{2}{ }^{-}\right) \mathrm{CH}_{2} \mathrm{CH}_{2} \mathrm{OH} & \rightarrow \mathrm{R}_{2} \mathrm{NCH}_{2} \mathrm{CH}_{2} \mathrm{~N}\left(\mathrm{COCO}_{2}{ }^{-}\right) \mathrm{CH}_{2} \mathrm{CH}_{2} \mathrm{OH} \\
\mathrm{R}_{2} \mathrm{NCH}_{2} \mathrm{CH}_{2} \mathrm{~N}\left(\mathrm{CH}_{2} \mathrm{CO}_{2}{ }^{-}\right) \mathrm{CH}_{2} \mathrm{CH}_{2} \mathrm{OH} & \rightarrow \mathrm{R}_{2} \mathrm{NCH}_{2} \mathrm{CH}_{2} \mathrm{~N}\left(\mathrm{CH}_{2} \mathrm{CO}_{2}{ }^{-}\right) \mathrm{COCH}_{2} \mathrm{OH} \\
\mathrm{R}_{2} \mathrm{NCH}_{2} \mathrm{CH}_{2} \mathrm{NH}\left(\mathrm{CH}_{2} \mathrm{CO}_{2}{ }^{-}\right) & \rightarrow \mathrm{R}_{2} \mathrm{NCH}_{2} \mathrm{CH}_{2} \mathrm{NH}\left(\mathrm{COCO}_{2}{ }^{-}\right) \\
\mathrm{R}_{2} \mathrm{NCH}_{2} \mathrm{CH}_{2} \mathrm{NH}\left(\mathrm{CH}_{2} \mathrm{CO}_{2}{ }^{-}\right) & \rightarrow \mathrm{R}_{2} \mathrm{NCH}_{2} \mathrm{CONH}\left(\mathrm{CH}_{2} \mathrm{CO}_{2}{ }^{-}\right)
\end{aligned}
$$

The hydrolysis reactions of these compounds provide primary or secondary amines:

$$
\begin{aligned}
& \mathrm{R}_{2} \mathrm{NCH}_{2} \mathrm{CON}\left(\mathrm{CH}_{2} \mathrm{CO}_{2}{ }^{-}\right) \mathrm{CH}_{2} \mathrm{CH}_{2} \mathrm{OH} \rightarrow \mathrm{R}_{2} \mathrm{NCH}_{2} \mathrm{CO}_{2}^{-}+\mathrm{HN}\left(\mathrm{CH}_{2} \mathrm{CO}_{2}{ }^{-}\right) \mathrm{CH}_{2} \mathrm{CH}_{2} \mathrm{OH} \\
& \mathrm{R}_{2} \mathrm{NCH}_{2} \mathrm{CH}_{2} \mathrm{~N}\left(\mathrm{COCO}_{2}{ }^{-}\right) \mathrm{CH}_{2} \mathrm{CH}_{2} \mathrm{OH} \rightarrow \mathrm{R}_{2} \mathrm{NCH}_{2} \mathrm{CH}_{2} \mathrm{NHCH}_{2} \mathrm{CH}_{2} \mathrm{OH}+{ }^{-} \mathrm{O}_{2} \mathrm{CCO}_{2}^{-} \\
& \mathrm{R}_{2} \mathrm{NCH}_{2} \mathrm{CH}_{2} \mathrm{~N}\left(\mathrm{CH}_{2} \mathrm{CO}_{2}{ }^{-}\right) \mathrm{COCH}_{2} \mathrm{OH} \rightarrow \mathrm{R}_{2} \mathrm{NCH}_{2} \mathrm{CH}_{2} \mathrm{NH}\left(\mathrm{CH}_{2} \mathrm{CO}_{2}{ }^{\circ}\right)+{ }^{-} \mathrm{O}_{2} \mathrm{CCH}_{2} \mathrm{OH} \\
& \mathrm{R}_{2} \mathrm{NCH}_{2} \mathrm{CH}_{2} \mathrm{NH}\left(\mathrm{COCO}_{2}^{-}\right) \rightarrow \mathrm{R}_{2} \mathrm{NCH}_{2} \mathrm{CH}_{2} \mathrm{NH}_{2}+{ }^{-} \mathrm{O}_{2} \mathrm{CCO}_{2}^{-} \\
& \mathrm{R}_{2} \mathrm{NCH}_{2} \mathrm{CONH}\left(\mathrm{CH}_{2} \mathrm{CO}_{2}^{-}\right) \rightarrow \mathrm{R}_{2} \mathrm{NCH}_{2} \mathrm{CO}_{2}^{-}+\mathrm{H}_{2} \mathrm{NCH}_{2} \mathrm{CO}_{2}^{-}
\end{aligned}
$$

The reactions eventually lead to primary amines as shown in the last two equations. Glycine is an important intermediate in the chemistry inasmuch as it can be envisioned as a product of many reactions. Glycine does not accumulate in the waste (Campbell et al. 1995a, 1995b, 1996a, $1996 \mathrm{~b}$ ) presumably because it is destroyed about five times more rapidly than the formate ion during radiolysis (Camaioni et al. 1997, 1998; Camaioni and Autrey 2000). However, it was readily detected as an intermediate in laboratory studies of the long-term decomposition of HEDTA in simulated waste (Barefield et al. 1995, 1996) and in investigations of the radiolysis of HEDTA, EDTA, NTA, and IDA (Camaioni et al. 1997, 1998). Plausible reaction paths that accommodate these observations are shown in the following equations:

$$
\begin{gathered}
\mathrm{R}_{2} \mathrm{NCH}_{2} \mathrm{CH}_{2} \mathrm{NH}_{2} \rightarrow \mathrm{R}_{2} \mathrm{NCH}_{2} \mathrm{CONH}_{2} \\
\mathrm{R}_{2} \mathrm{NCH}_{2} \mathrm{CONH}_{2} \rightarrow \mathrm{R}_{2} \mathrm{NCH}_{2} \mathrm{CO}_{2}^{-}+\mathrm{NH}_{3}
\end{gathered}
$$




\section{$\mathrm{H}_{2} \mathrm{NCH}_{2} \mathrm{CO}_{2}^{-} \rightarrow \mathrm{H}_{2} \mathrm{NCOCO}_{2}^{-}$ \\ $\mathrm{H}_{2} \mathrm{NCOCO}_{2}^{-} \rightarrow \mathrm{NH}_{3}+{ }^{-} \mathrm{O}_{2} \mathrm{CCO}_{2}^{-}$}

The reaction processes describe sequences for the conversion of HEDTA and EDTA into the remnants that are observed in waste and in simulants. The low concentrations of ammonia in the waste coupled with the high activation energy for the reaction of ammonia with the carboxylate ion prevent the reconstitution of the amides. This chemistry and the constant evolution of ammonia from the waste drive these reactions forward.

4.5.3.3.2 Ammonia from Nitriles. Primary oximes and primary amides can be converted into nitriles by dehydration reactions in the alkaline wastes. Barefield et al. (1995, 1996) found small concentrations of nitriles in long-term studies of the decomposition pathways of HEDTA in simulated wastes. Simple aliphatic nitriles with more than four carbon atoms have been detected in the dome space of many Hanford Site tanks (Huckaby et al. 1996; Stock and Huckaby 2000). Although these substances are apparently derived from NPHs, their existence in the waste provides a good precedent for the formation of other nitriles from the nonvolatile complexants.

The path to ammonia through the nitrile is illustrated in the following equations by the oxidation and dehydration of $\mathrm{u}-\mathrm{ED} 2 \mathrm{~A}$ and the subsequent hydrolysis of the nitrile

$$
\begin{gathered}
\mathrm{R}_{2} \mathrm{NCH}_{2} \mathrm{CH}_{2} \mathrm{NH}_{2} \rightarrow \mathrm{R}_{2} \mathrm{NCH}_{2} \mathrm{CONH}_{2} \\
\mathrm{R}_{2} \mathrm{NCH}_{2} \mathrm{CONH}_{2} \rightarrow \mathrm{R}_{2} \mathrm{NCH}_{2} \mathrm{CN}+\mathrm{H}_{2} \mathrm{O} \\
\mathrm{R}_{2} \mathrm{NCH}_{2} \mathrm{CN}+\mathrm{H}_{2} \mathrm{O}+\mathrm{OH}^{-} \rightarrow \mathrm{R}_{2} \mathrm{NCH}_{2} \mathrm{CO}_{2}^{-}+\mathrm{NH}_{3}
\end{gathered}
$$

where $\mathrm{R}=\mathrm{CH}_{2} \mathrm{CO}_{2}^{-}$.

The oxidation, dehydration, and hydrolysis reactions of the nitroso compounds, nitriles, and the amides are closely related processes. Similar intermediates are involved in the reactions of this family of compounds. Specifically, an aldoxime can be dehydrated to produce the nitrile, and the initial product of hydrolysis of the nitrile is the corresponding amide. This reaction pattern is best illustrated by the reactive intermediates obtained from an NPH:

$$
\begin{gathered}
\mathrm{AlkylCH}_{2} \mathrm{CHNO} \rightarrow \mathrm{AlkylCH}_{2} \mathrm{CH}=\mathrm{NOH} \rightarrow \mathrm{AlkylCH}_{2} \mathrm{CN} \\
\mathrm{AlkylCH}_{2} \mathrm{CN} \rightarrow \mathrm{AlkylCH}_{2} \mathrm{CONH}_{2} \rightarrow \mathrm{AlkylCH}_{2} \mathrm{CO}_{2}+\mathrm{NH}_{3}
\end{gathered}
$$

Ashby et al. (1994) demonstrated the reality of this pathway by showing that the aldoxime of formaldehyde was converted first into sodium cyanide, and that the sodium cyanide then formed sodium formate and ammonia.

In summary, ammonia is produced from tertiary amines such as EDTA and HEDTA by oxidation-hydrolysis sequences that eventually provide an intermediate with a primary amino group. Repetition of the reaction sequence gives a primary amide. Such compounds either hydrolyze directly to produce ammonia or are converted to a nitrile that subsequently hydrolyzes 
by a similar reaction pathway to form ammonia. Solvent molecules react in a similar fashion. In this instance, the nitrile is formed by the dehydration of the oxime.

4.5.3.3.3 Ammonia from Cyanate Anions. Ammonia can be formed via the decomposition of cyanate anion, $\mathrm{OCN}^{*}$. The cyanate ion can be formed in the wastes by the dehydration of the adduct of the nitrosyl anion and formaldehyde:

$$
\mathrm{H}_{2} \mathrm{CO}+\mathrm{NO}^{-} \rightarrow \mathrm{ONCH}_{2} \mathrm{O}^{-} \rightarrow \mathrm{OCN}^{-}+\mathrm{H}_{2} \mathrm{O}
$$

The cyanate anion decomposes in both acidic and alkaline aqueous solutions to yield ammonia and carbon dioxide (Cotton and Wilkinson 1988). March (1992) and Barefield et al. (1995, 1996) suggest the reaction proceeds through the hydroxamate ion:

$$
\mathrm{OCN}^{-}+2 \mathrm{H}_{2} \mathrm{O} \rightarrow\left[\mathrm{H}_{2} \mathrm{NC}(=\mathrm{O}) \mathrm{O}^{-}\right]+\mathrm{H}_{2} \mathrm{O} \rightarrow \mathrm{CO}_{3}^{-2}+\mathrm{NH}_{3}
$$

Urea also is listed as a decomposition product of the cyanate anion in aqueous solutions (Windholz et al. 1976). This compound is readily hydrolyzed in alkaline solutions to liberate ammonia and carbonate ions.

\subsubsection{Methane and Volatile Organic Compound Formation}

Methane and other volatile organic compounds emerge from the waste with the other permanent gases. Methane and possibly ethane can be obtained from the complexants, but the reaction pathways for their formation are limited because the original complexants contain neither methyl nor ethyl groups and the routes for the formation of the methyl and ethyl radicals necessary for the formation of methane are circuitous. The most direct route from the original complexants to methane is through the acetate ion, which is produced during the base-catalyzed decomposition of the citrate ion.

$$
\mathrm{HOC}\left(\mathrm{CH}_{2} \mathrm{CO}_{2}^{-}\right)_{2} \mathrm{CO}_{2}^{-} \rightarrow \rightarrow \mathrm{CH}_{3} \mathrm{CO}_{2}^{-} \rightarrow \rightarrow \mathrm{CH}_{3} \rightarrow \mathrm{CH}_{4}
$$

The N-methyl compounds produced during the decomposition of EDTA and HEDTA and dimethyl amine, which can also originate from these complexants, are possible sources of methane:

$$
\begin{gathered}
\mathrm{EDTA} \rightarrow \rightarrow\left(\mathrm{O}_{2} \mathrm{CCH}_{2}\right)_{2} \mathrm{CH}_{2} \mathrm{CH}_{2} \mathrm{NHCH}_{3} \rightarrow \rightarrow \mathrm{CH}_{3} \rightarrow \mathrm{CH}_{4} \\
\left(\mathrm{O}_{2} \mathrm{CCH}_{2}\right)_{2} \mathrm{CH}_{2} \mathrm{CH}_{2} \mathrm{NHCH}_{3} \rightarrow \rightarrow \mathrm{CH}_{3} \mathrm{NHCH}_{3} \rightarrow \rightarrow \mathrm{CH}_{3} \rightarrow \mathrm{CH}_{4}
\end{gathered}
$$

In contrast, methane, ethane, and the other volatile organic compounds such as propane, butane, ethene, propene, and butene arise very directly during the oxidation reactions of the phosphate esters and NPHs. The alkyl radicals formed in the course of their reactions fragment to form alkenes and alkyl radicals. The alkyl radicals either react with a nitrogen oxide or abstract a hydrogen atom from another molecule to produce the alkane. 


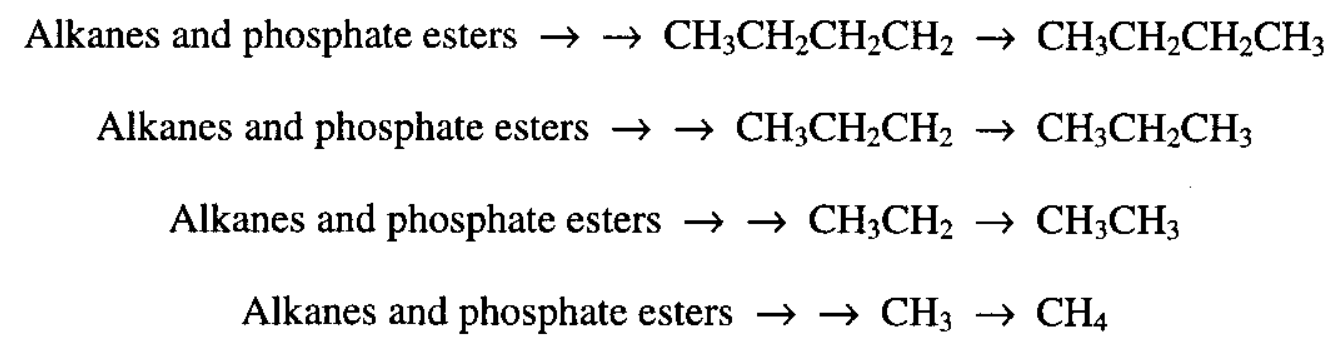

The diverse mixture of solvent molecules leads to a diverse mixture of alkyl radicals and alkanes. However, there are other pathways to radicals with one to four carbon atoms, and the predominant products - methane, ethane, propane and butane - are generally detectable in the emerging gases together with the corresponding low molecular weight alkenes and the other oxidized products.

\subsubsection{Role of Oxygen}

Oxygen plays a significant role in the chemistry of Hanford Site wastes. Results from the Retained Gas Sampling Program indicate that oxygen produced by the radiolysis of water is consumed. In laboratory work, the addition of oxygen results in changes in reaction rates and product distributions. While there are significant quantitative differences in the results obtained in different laboratories, the published reports affirm that oxygen importantly influences the rate of decomposition of organic complexants and significantly alters the product distribution by increasing the relative rate of formation of hydrogen and sodium oxalate and by decreasing the relative rate of formation of sodium formate and nitrogenous gases (Barefield et al. 1995, 1996; Person 1996, 1998; Camaioni et al. 1996b, 1997; Pederson and Bryan 1996). The available data indicate that oxygen has essentially the same influence on thermal and radiolytic reactions. Some illustrative results are examined in this section.

The potential impact of oxygen on the course of the reactions is highlighted in the Georgia Institute of Technology study of the decomposition of HEDTA at $120^{\circ} \mathrm{C}$ (Barefield et al. 1996). As shown in Table 4-9, experiments were conducted under argon and contrasted with the results obtained under oxygen. Measurements at other times and temperatures indicate the same general trends.

Oxygen slows the thermal and radiolytic conversion of organic complexants. Oxygen also decreases the yields of the three nitrogen-containing gases and reduces the consumption of the nitrite ion. Oxygen increases the rate of hydrogen formation significantly. In the example shown in Table 4-9, hydrogen production is increased by a factor of 8 . Oxygen decreases the yield of the formate ion, but increases the yield of the oxalate ion. 
Table 4-9. Moles of Decomposition Product per 100 Moles of Hydroxyethylethylenediaminetriacetate after 200 Hours in Simulated Hanford Site Waste at $120^{\circ} \mathrm{C}$.

\begin{tabular}{|c|c|c|c|c|c|c|c|c|}
\hline Gas & HEDTA & ED3A & Oxalate & Formate & $\mathbf{H}_{\mathbf{2}}$ & $\mathbf{N}_{\mathbf{2}}$ & $\mathbf{N}_{\mathbf{2}} \mathbf{O}$ & $\mathbf{N H}_{\mathbf{3}}$ \\
\hline $\mathrm{Ar}$ & 42 & 46 & 4 & 75 & 1 & 11 & 32 & 40 \\
\hline $\mathrm{Ar}$ & 45 & 46 & & 72 & 1 & 9 & 30 & \\
\hline $\mathrm{O}_{2}$ & 86 & 7 & 8 & 15 & 8 & $<1$ & $<1$ & 4 \\
\hline
\end{tabular}

Note: Information in this table is from

- Barefield, E. K., D. Boatright, A. Desphande, R. Doctorovich, C. L. Liotta, H. M. Neumann, and S. Seymore, 1996, Mechanisms of Gas Generation from Simulated SY Tank Farm Wastes: FY 1995 Progress Report, PNL-11247, Pacific Northwest Laboratory, Richland, Washington.

ED3A = ethylenediaminetriacetate ion.

HEDTA = hydroxyethylethylenediaminetriacetate ion .

As already mentioned, observations from the different laboratories are quantitatively different, but there is generally good agreement concerning the major features of the work and the role of oxygen in gas generation (Barefield et al. 1995, 1996; Pederson and Bryan 1996; Camaioni et al. 1995, 1996b; Person 1996, 1998). Collectively, the observations indicate that the usual radiation-promoted, base-catalyzed reactions provide more highly oxidized organic products when oxygen is present. This change is accompanied by a large decrease in the yields of ammonia, nitrogen, and nitrous oxide.

In view of the fact that oxygen in an alkaline solution is known to convert alcohols to ketones and carboxylate anions (Lowry and Richardson 1987; Carey and Sundberg 1990; March 1992), the major change in the reaction pathway is not surprising. However, the finding that the dihydrogen yield increases by almost a factor of 10 (Barefield et al. 1996) may not have been anticipated.

The chemical reactions between oxygen and nitric oxide and their elementary derivatives have been investigated with some intensity during the past decade because of their roles in biological systems. Nevertheless, many uncertainties remain, and the simple interpretation that is outlined here is probably naïve. In any event, oxygen reacts with the radicals and atoms produced in radiolytic and thermal reactions, converting them to new materials that possess higher oxidation potentials. The most important reaction of this type is the reaction of oxygen with nitrosyl anions to form peroxynitrite ions, which rearrange to nitrate anions (Stern et al. 1996):

$$
\begin{gathered}
\mathrm{O}_{2}+\mathrm{NO}^{-} \rightarrow{ }^{-} \mathrm{OONO} \\
{ }^{-} \mathrm{OONO} \rightarrow \mathrm{NO}_{3}^{-}
\end{gathered}
$$

The lifetime for conversion of peroxynitrite ion to nitrite is approximately 1 second in neutral solution when dissolved oxygen is present (Fukuto and Ignarro 1997).

Oxygen also reacts directly with the intermediate organic radicals discussed in Section 2.2 to form hydroperoxides, which are eventually converted into the same oxidized organic substances 
obtained by the other reactions. However, oxidation in the presence of oxygen negates the reaction pathways involving the nitrogen oxides and curtails the formation of $\mathrm{C}$ - and $\mathrm{N}$-nitroso and nitro compounds and thereby reduces the formation of nitrogen-containing gases. The hydroperoxide pathways are illustrated for a radical derived from HEDTA to show the behavior of the complexants and solvents:

$$
\begin{gathered}
\mathrm{RN}\left(\mathrm{CH}_{2} \mathrm{CO}_{2}^{-}\right) \mathrm{CHCH}_{2} \mathrm{OH}+\mathrm{O}_{2} \rightarrow \mathrm{RN}\left(\mathrm{CH}_{2} \mathrm{CO}_{2}{ }^{-}\right) \mathrm{CH}(\mathrm{OO}) \mathrm{CH}_{2} \mathrm{OH} \\
\mathrm{RN}\left(\mathrm{CH}_{2} \mathrm{CO}_{2}{ }^{-}\right) \mathrm{CH}(\mathrm{OO}) \mathrm{CH}_{2} \mathrm{OH}+\mathrm{HDonor} \rightarrow \mathrm{RN}\left(\mathrm{CH}_{2} \mathrm{CO}_{2}{ }^{-}\right) \mathrm{CH}(\mathrm{OOH}) \mathrm{CH}_{2} \mathrm{OH}+\text { Radical } \\
\mathrm{RN}\left(\mathrm{CH}_{2} \mathrm{CO}_{2}{ }^{-}\right) \mathrm{CH}(\mathrm{OOH}) \mathrm{CH}_{2} \mathrm{OH}+\mathrm{O}_{2}+\mathrm{OH}^{-} \rightarrow \mathrm{RN}\left(\mathrm{CH}_{2} \mathrm{CO}_{2}{ }^{-}\right) \mathrm{C}(\mathrm{O}) \mathrm{CO}_{2}^{-}+3 \mathrm{H}_{2} \mathrm{O} \\
\mathrm{RN}^{-}\left(\mathrm{CH}_{2} \mathrm{CO}_{2}{ }^{-}\right) \mathrm{C}(\mathrm{O}) \mathrm{CO}_{2}{ }^{-}+\mathrm{OH}^{-} \rightarrow \mathrm{RNH}\left(\mathrm{CH}_{2} \mathrm{CO}_{2}{ }^{-}\right)+{ }^{-} \mathrm{O}_{2} \mathrm{CCO}_{2}{ }^{-}
\end{gathered}
$$

The greater potential for oxidation is illustrated in the laboratory investigations by the higher relative yield of oxalate ion and the lower relative yield of nitrogen-containing gases.

The increased amount of hydrogen formed in the simulants and the wastes in the presence of oxygen is especially interesting. The results in Table 4-9 show 8 moles of hydrogen and 15 moles of formate ion are formed in the presence of oxygen. If formate ion comes from the available formaldehyde, then the reaction pathway that leads to hydrogen in the presence of oxygen is about $50 \%$ efficient. Previous studies in less complex solutions have found that formaldehyde, sodium hydroxide, and sodium peroxide provide hydrogen with $100 \%$ efficiency (Abel 1956; Coffey 1965). It therefore seems reasonable to suggest that the role of oxygen in the alkaline solutions is to provide the same intermediate that is responsible for the formation of hydrogen from formaldehyde. As already discussed, Ashby et al. (1993, 1994) proposed that the intermediate in the absence of oxygen was $\mathrm{H}_{2} \mathrm{C}(\mathrm{O}-)_{2}$ and suggested that hydrogen was formed by the reaction of this dianion with water. The reactions in the presence of oxygen can be formulated in the same manner except with the hydroperoxide anion replacing the hydroxide ion:

$$
\begin{gathered}
\mathrm{H}_{2} \mathrm{CO}+\mathrm{HOO}^{-} \rightarrow \mathrm{H}_{2} \mathrm{C}\left(\mathrm{O}^{-}\right)(\mathrm{OOH}) \\
\mathrm{H}_{2} \mathrm{C}\left(\mathrm{O}^{-}\right)(\mathrm{OOH})+\mathrm{HO}^{-} \rightarrow \mathrm{H}_{2} \mathrm{C}\left(\mathrm{O}^{-}\right)\left(\mathrm{OO}^{-}\right)+\mathrm{H}_{2} \mathrm{O} \\
\mathrm{H}_{2} \mathrm{C}\left(\mathrm{O}^{-}\right)\left(\mathrm{OO}^{-}\right)+\mathrm{H}_{2} \mathrm{O} \rightarrow \mathrm{HC}(\mathrm{O})\left(\mathrm{OO}^{-}\right)+\mathrm{H}_{2}+\mathrm{OH}^{-}
\end{gathered}
$$

The greater efficiency of this process in the presence of peroxides may be understood quite readily on the basis of the much more favorable formation constants for the tetrahedral intermediates. That is, other factors being equal, the equilibrium concentration of $\mathrm{H}_{2} \mathrm{C}\left(\mathrm{O}^{-}\right)(\mathrm{OOH})$ exceeds the concentration of $\mathrm{H}_{2} \mathrm{C}\left(\mathrm{O}^{-}\right)(\mathrm{OH})$. It is well known that the $\mathrm{HOO}^{-}$ anion is more nucleophilic than the $\mathrm{HO}^{-}$anion (Jencks 1969; March 1992). Perhaps even more important is the fact that the hydroperoxyl proton is a much stronger acid than the hydroxyl proton by approximately four orders of magnitude. Consequently, there is a major advantage for the formation of the important dianion $\mathrm{H}_{2} \mathrm{C}\left(\mathrm{O}^{-}\right)\left(\mathrm{OO}^{-}\right)$from which hydrogen is produced by the reaction with water.

The results of the laboratory investigations are in reasonable accord with the investigations of the waste. For example, laboratory work has established that the oxygen-forming intermediate 


\section{RPP-6664 REV 0}

atoms and radicals produced during radiolysis are rapidly consumed (Meisel et al. 1991a, 1991b, 1993, 2000; Fessenden et al. 2000), and work with the waste has shown that the dioxygen content in the lower portions of the waste is small (Shekarriz et al. 1997; Mahoney et al. 1999). It is also known that freshly cored samples of waste from tank 241-SY-101 react with oxygen (Person 1996, 1998). The thermal aging investigations (Barefield et al. 1995, 1996) and radiolytic aging experiments in the presence of air (Camaioni et al. 1995, 1996b, 1997; Camaioni and Autrey 2000) show sodium carbonate and sodium oxalate as the most abundant products. The observations imply that the chemistry in the plausibly more oxygen-rich upper regions of the waste may differ from the chemistry of the waste in the oxygen-poor lower regions of the waste, but the concept has not been verified during analytical investigations of the composition of the waste.

In summary, oxygen can alter the course of thermal and radiolytic reactions. Hydrogen is formed more rapidly, and the organic products of the reactions are more completely oxidized than the products of the conventional reaction, providing sodium oxalate rather than sodium formate.

\subsection{EQUIVALENCE OF ORGANIC OXIDATION AND GAS FORMATION}

Camaioni et al. (1998) have discussed the rates of oxidation of organic compounds in waste, and Person $(1996,1998)$ has examined the equivalence between the rate of oxidation of the organic complexants and the rate of gas formation. Gas formation and the destruction of the complexants are coupled oxidation-reduction reactions. Half reactions illustrating the most important processes are shown in the following equations.

$$
\begin{gathered}
2 \mathrm{H}_{2} \mathrm{O}+2 \mathrm{e}^{-} \rightarrow \mathrm{H}_{2}+2 \mathrm{OH}^{-} \\
2 \mathrm{NO}_{2}^{-}+3 \mathrm{H}_{2} \mathrm{O}+4 \mathrm{e}^{-} \rightarrow \mathrm{N}_{2} \mathrm{O}+6 \mathrm{OH}^{-} \\
2 \mathrm{NO}_{2}^{-}+4 \mathrm{H}_{2} \mathrm{O}+6 \mathrm{e}^{-} \rightarrow \mathrm{N}_{2}+8 \mathrm{OH}^{-} \\
\mathrm{NO}_{2}^{-}+5 \mathrm{H}_{2} \mathrm{O}+6 \mathrm{e}^{-} \rightarrow \mathrm{NH}_{3}+7 \mathrm{OH}^{-} \\
2 \mathrm{NO}_{2}+3 \mathrm{H}_{2} \mathrm{O}+6 \mathrm{e}^{-} \rightarrow \mathrm{N}_{2} \mathrm{O}+6 \mathrm{OH}^{-} \\
2 \mathrm{NO}_{2}+4 \mathrm{H}_{2} \mathrm{O}+8 \mathrm{e}^{-} \rightarrow \mathrm{N}_{2}+8 \mathrm{OH}^{-} \\
\mathrm{NO}_{2}+5 \mathrm{H}_{2} \mathrm{O}+7 \mathrm{e}^{-} \rightarrow \mathrm{NH}_{3}+7 \mathrm{OH}^{-}
\end{gathered}
$$

The reduction of water and of nitrite ions and nitrogen dioxide requires from two to eight electrons. As noted previously, the reduction reactions of nitrite ion and nitrogen dioxide that form the nitrogen-containing gases require from two to four times more electrons than are required by the reduction of water that forms hydrogen.

The oxidation of the glycinate ion is shown to illustrate the electron transfers required for the oxidation of a typical organic fragment. Oxidation resulting in the formation of the oxalate ion, 


\section{RPP-6664 REV 0}

which can occur by the processes described earlier, is shown in the first equation. Oxidation resulting in fragmentation to form formate and carbonate ions is shown in the second equation. Each process provides four electrons per mole of glycinate ion.

$$
\begin{gathered}
5 \mathrm{OH}^{-}+\mathrm{H}_{2} \mathrm{NCH}_{2} \mathrm{CO}_{2}^{-} \rightarrow \mathrm{NH}_{3}+\mathrm{O}_{2} \mathrm{CCCO}_{2}^{-}+3 \mathrm{H}_{2} \mathrm{O}+4 \mathrm{e}^{-} \\
6 \mathrm{OH}^{-}+\mathrm{H}_{2} \mathrm{NCH}_{2} \mathrm{CO}_{2}^{-} \rightarrow \mathrm{NH}_{3}+\mathrm{CO}_{3}^{2-}+\mathrm{HCO}_{2}^{-}+3 \mathrm{H}_{2} \mathrm{O}+4 \mathrm{e}^{-}
\end{gathered}
$$

Analysis of the reaction pathways for gas formation suggests that hydrogen is often formed from formaldehyde, an intermediate in the oxidation of the glycinate ion. Two electrons are transferred in the process that yields hydrogen as well as formate and carbonate ions.

$$
4 \mathrm{OH}^{-}+\mathrm{H}_{2} \mathrm{NCH}_{2} \mathrm{CO}_{2}{ }^{-} \rightarrow \mathrm{NH}_{3}+\mathrm{CO}_{3}{ }^{2-}+\mathrm{HCO}_{2}^{-}+\mathrm{H}_{2} \mathrm{O}+\mathrm{H}_{2}+2 \mathrm{e}^{-}
$$

In principle, information about the rates at which the organic compounds react can provide information about the rates at which the gases are formed. Person $(1996,1998)$ has specifically discussed the rates of oxidation implied by the observed rates of gas formation. His work is complemented by the work of Camaioni et al. (Camaioni et al. 1998; Camaioni and Autrey 2000 ), who examined the rates of oxidation.

The application of these concepts can be conveniently illustrated by a discussion of the rate of gas formation in tank 241-SY-101. Before the waste transfers that occurred in 2000, tank 241-SY-101 produced about 20 moles of nitrogen, 40 moles of hydrogen, and 40 moles of nitrous oxide per day. The yearly rate of gas production was 7,300 moles of nitrogen, 14,600 moles of nitrous oxide, and 14,600 moles of hydrogen. The amounts of nitrogen and nitrous oxide formed from nitrite ions require the transfer of 102,000 moles of electrons. The formation of hydrogen requires the transfer of an additional 29,200 moles of electrons. The rate of gas formation required the transfer of approximately 117,000 moles of electrons per year from the organic complexants.

Adopting the viewpoint that the oxidation reaction is initiated in $50 \%$ of the reactions by hydrogen atom abstraction and in the other $50 \%$ by electron transfer yields the following:

$$
\begin{gathered}
5 \mathrm{OH}^{-}+\mathrm{H}_{2} \mathrm{NCH}_{2} \mathrm{CO}_{2}^{-} \rightarrow \mathrm{NH}_{3}+\mathrm{O}_{2} \mathrm{CCCO}_{2}^{-}+3 \mathrm{H}_{2} \mathrm{O}+4 \mathrm{e}^{-} \\
4 \mathrm{OH}^{-}+\mathrm{H}_{2} \mathrm{NCH}_{2} \mathrm{CO}_{2}^{-} \rightarrow \mathrm{NH}_{3}+\mathrm{CO}_{3}{ }^{2-}+\mathrm{HCO}_{2}{ }^{-}+\mathrm{H}_{2} \mathrm{O}+\mathrm{H}_{2}+2 \mathrm{e}^{-}
\end{gathered}
$$

This reaction system requires the oxidation of about 40,000 moles of carboxymethyl groups each year. The reaction system outlined here would provide about 20,000 moles of oxalate, 20,000 moles of formate ions, and 20,000 moles of carbonate ions per year. The formation of these three substances reduces the fuel value of the waste, but only the formation of carbonate ions reduces the TOC content. The calculated change in TOC is modest at about $0.04 \mathrm{~g} / \mathrm{L}$ per year.

A comparison of the waste composition that was predicted for tank 241-SY-101 circa 1980 by Agnew et al. (1997) and the composition of the waste circa 1995 as observed by Campbell et al. (1995a, 1995b, 1996a, 1996b, 1997) is shown in Table 4-10. The comparison provides support for the relationship between organic oxidation and gas formation. 
Table 4-10. The Organic Content of the Waste in Tank 241-SY-101 in 1980 and in 1995 in Thousands of Moles.

\begin{tabular}{|c|c|c|}
\hline Organic lon & Hanford Defined Waste Model & Analysis \\
Circa 1980 & Circa 1995 $^{\mathbf{b}}$ \\
\hline EDTA & 109 & 89 \\
\hline HEDTA & 207 & 0 \\
\hline ED3A & 0 & 21 \\
\hline NTA & 0 & 27 \\
\hline IDA & 0 & 134 \\
\hline Glycolate & 580 & 81 \\
\hline Citrate & 164 & 30 \\
\hline Acetate & 40 & 121 \\
\hline Formate & 0 & 574 \\
\hline Oxalate & 0 & 1,050 \\
\hline Succinate & 0 & 9 \\
\hline
\end{tabular}

${ }^{\mathrm{a}}$ Agnew, S. F., R. A. Corbin, T. B. Duran, K. A. Jurgenson, J. Fitzpatrick, B. L. Young, J. Boyer, and T. P. Ortiz, 1997, Hanford Tank Chemical and Radionuclide Inventories: Hanford Defined Wastes (HDW) Model, Rev. 4, WHC-SD-WM-TI-615, Westinghouse Hanford Company, Richland, Washington.

'Infomation from the following reports:

- Campbell, J. A., R. M. Bean, K. L. Wahl, G. M. Mong, K. E. Bell, K. B. Werner, A. D. Rice, R. J. Ray, D. B. Bechtold, B. R. Wels, R. W. Schroeder, J. W. Ball, B. D. Valenzuela, J. M. Frye, S. L. Fitzgerald, P. P. Bachelor, B. Griffin, R. K. Fuller, A. B. Benally, and S. M. Parong, 1995a, Waste Tank Analytical Safety Project. Analysis of Samples from Hanford Waste Tanks 241-C-102, 241-BY-108, and 241-C-103, PNNL-10531, Pacific Northwest National Laboratory, Richland, Washington.

- Campbell, J. A., S. A. Clauss, V. Hoopes, J. Rau, K. L. Wahl, B. D. Lerner, K. E. Grant, G. M. Mong, and R. Scheele, 1995b, Flammable Gas Program Organic Analysis and Analytical Methods Development: FY 1995 Progress Report, PNNL-10776, Pacific Northwest National Laboratory, Richland, Washington.

- Campbell, J. A., K. L Wahl, S. A. Clauss, K. E. Grant, V. Hoopes, G. M. Mong, J. Rau, and R. Steele, 1996a, Organic Tanks Safety Program: Advanced Organic Analysis FY 1996 Progress Report, PNNL-11309, Pacific Northwest National Laboratory, Richland, Washington.

- Campbell, J. A., S. A. Clauss, K. E. Grant, V. Hoopes, G. M. Mong, J. Rau, R. Steele, and K. H. Wahl, 1996b, Flammable Gas Safety Program: Actual Waste Organic Analysis FY 1996 Progress Report, PNNL-11307, Pacific Northwest National Laboratory, Richland, Washington.

- Campbell, J. A., S. A. Clauss, K. E. Grant, V. Hoopes, G. M. Mong, R. Steele, D. Bellofatto, and A. Sharma, 1997, Organic Analysis Progress Report FY 1997, PNNL-11738, Pacific Northwest National Laboratory, Richland, Washington.

$\mathrm{ED} 3 \mathrm{~A}=$ ethylenediaminetriacetate ion. EDTA = ethylenediaminetetraacetate ion. HEDTA $=$ hydroxyethylethylenediaminetriacetate ion.
IDA $=$ iminodiacetate ion.

NTA $=$ nitrilotriacetate ion.

The TOC content decreased only from about $64,000 \mathrm{~kg}$ to $60,000 \mathrm{~kg}$, but the distribution of carbon in the waste changed appreciably, with large reductions in the concentrations of the original complexants and the formation of relatively large amounts of acetate, formate, and oxalate ions as well as remnants of the nitrogen-containing complexants. The Hanford defined 
waste approach implies that the tank originally contained about 2,700 kilomoles of carboxymethyl groups. The analytical results imply that 1,500 kilomoles of these groups were oxidized, at a rate of approximately 100,000 moles per year, to formate, oxalate, and carbonate ions in the 15-year interval.

The rate of oxidation implied in Table 4-10 is considerably larger than the rate of oxidation implied by the present rate of gas formation. The rate of gas formation necessarily decreases with time as the radiation intensity, the temperature, and the abundance of organic hydrogen systematically decrease, reducing the rates of oxidation and gas formation. Moreover, evaporator operations, which would have enhanced the oxidation rate, are not considered in the analysis.

Person (1998) applied these concepts to evaluate the rate of disappearance of the organic compounds in tank 241-AN-105. His findings are summarized in Table 4-11.

Table 4-11. Predicted Rates of Oxidation of Organic Carbon to Oxalate and Carbonate Ion in Tank 241-AN-105 Based upon Observed Rates of Gas Generation.

\begin{tabular}{|c|c|c|}
\hline $\begin{array}{r}\text { Estimate 1. Oxidation rate of } 72 \text { eq/day from observed rate of gas generation for which the } \\
\text { minimum G value for equivalent gas reduction is } 0.06 \text { molecules/100 eV. }\end{array}$ & $\begin{array}{c}\text { Oxalate } \\
\text { Carbonate }\end{array}$ \\
\hline Rate (kmole TOC/yr) & 13.1 & 8.7 \\
\hline Half-life (years) & 51.8 & 77.7 \\
\hline Estimate 2. Oxidation rate of 175 eq/day from observed thermal rate of gas generation for \\
which the G value for equivalent reduction is 1.8 molecules/100 eV.* \\
\hline Rate (kmole TOC/yr) & 32.0 & 21.3 \\
\hline Half-life (years) & 21.2 & 31.8 \\
\hline
\end{tabular}

Note: Information in this table is from Person, J. C., 1998, Gas Generation in Tank 241-AN-105 Waste With and Without Oxygen Reactions, HNF-2038, Numatec Hanford Corp. for Fluor Daniel Hanford, Inc., Richland, Washington.

* Camaioni, D. M., W. D. Samuels, J. C. Linehan, S. A. Clauss, A. K. Sharma, K. L. Wahl, and J. A. Campbell, 1996b, FY 1996 Waste Aging Studies, PNNL-11312, Pacific Northwest National Laboratory, Richland, Washington.

$\mathrm{G}=$ generation efficiency in moles $/ 100 \mathrm{eV}$.

TOC $=$ total organic carbon.

The large differences between the observed gas generation rates and the observed oxidation rates imply that the gas generation rates can only be used to estimate the minimum rate of oxidation of the organic constituents.

As previously mentioned, Pederson and Bryan (1996) compared the observed radiolytic rate of hydrogen formation in tank 241-SY-103 with the rate of hydrogen formation anticipated from the application of the Meisel equation. They also reported that the predicted value was considerably smaller than the observed value. 


\section{RPP-6664 REV 0}

\subsection{REACTIONS OF GASES IN WASTE}

Gases are retained in some Hanford Site waste for years. Consequently, radiolytic and thermal reactions of the gases with each other and with the other constituents of the waste have been investigated to determine whether those chemical reactions alter the composition of the mixtures. Bryan and Pederson (1995) investigated the decomposition of nitrous oxide to produce nitrogen and oxygen; the reaction between nitrogen and hydrogen to form ammonia as the principal product; the reaction between nitrous oxide and hydrogen to form ammonia, nitrogen, and nitrogen dioxide; and the decomposition of ammonia. They conducted tests with the gases alone and with the gases in contact with dried and moist simulated waste. The thermal reactions were investigated in the temperature range from $60^{\circ} \mathrm{C}$ to $150^{\circ} \mathrm{C}$ in the absence of radiation. The radiolysis reactions were carried out with a radiation dose of about $10^{7} \mathrm{R}$, which is equivalent to 1 year of storage in tank 241-SY-101.

The thermal and combined thermal and radiolytic decomposition of nitrous oxide was investigated, and no detectable decomposition occurred when the pure gas was heated for 150 hours at $150^{\circ} \mathrm{C}$. This observation is in accord with earlier studies of the thermal decomposition of nitrous oxide (Preston and Cvetanovic 1972) implying that $1 \%$ of nitrous oxide decomposes after 1,000 hours at $400{ }^{\circ} \mathrm{C}$.

Nitrous oxide decomposed when heated at between $60^{\circ} \mathrm{C}$ and $150{ }^{\circ} \mathrm{C}$ in the presence of dried and moist simulated waste. There was no clear dependence on the temperature. Between $0.4 \%$ and $1.1 \%$ of the nitrous oxide was consumed in 150 hours at $120^{\circ} \mathrm{C}$ in the presence of moist simulant, and between $1.2 \%$ and $1.5 \%$ was consumed in the presence of dry simulant.

Nitrous oxide also decomposes during radiolysis. The $\mathrm{G}$ values for the decomposition of nitrous oxide and the formation of nitrogen, oxygen, and other nitrogen oxides obtained by Harteck and Dondes (1956) at $25^{\circ} \mathrm{C}$ and by Bryan and Pederson (1995) at between $60^{\circ} \mathrm{C}$ and $150{ }^{\circ} \mathrm{C}$ for the pure substance are shown in Figure 4-4. The radiolysis reaction also was investigated in the presence of dry and moist waste simulants (Bryan and Pederson 1995). Nitrogen was the major product of the reaction under these conditions; nitrogen dioxide and the other oxides were apparently consumed in the waste. 
Figure 4-4. Generation Efficiency Values for the Decomposition of Nitrous Oxide and Product Formation at Temperatures Ranging from $25^{\circ} \mathrm{C}$ to $150^{\circ} \mathrm{C}$.

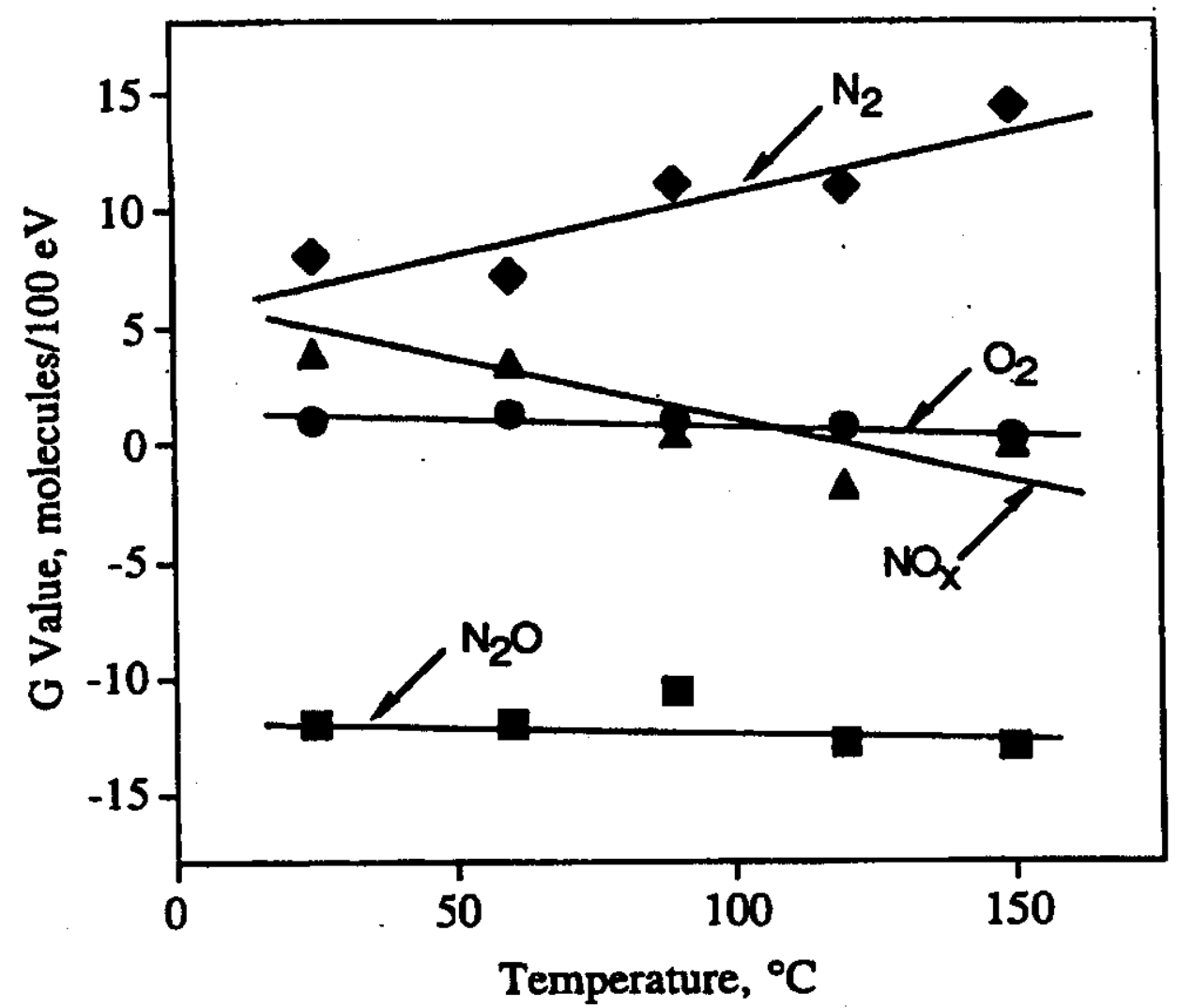

The experimentally determined $\mathrm{G}$ value of -12 molecules $/ 100 \mathrm{eV}$ for $\mathrm{N}_{2} \mathrm{O}$ is applicable for the consumption of nitrous oxide by radiation at high and low temperatures. This value indicates that $0.9 \%$ nitrous oxide would be consumed in 1 year at a dose rate of $1,000 \mathrm{R} / \mathrm{h}$. Bryan and Pederson (1995) conclude that the gas phase decomposition of nitrous oxide is of minor importance in waste.

The thermal and radiolytic reactions of mixtures of nitrous oxide and hydrogen also were investigated (Bryan and Pederson 1995, Pederson and Bryan 1996). The thermal decomposition of nitrous oxide in mixtures of the pure gases in argon occurred much more rapidly in the presence of hydrogen, as was expected based on prior work by Hertzberg and Zlochower (1994). Typically $5 \%$ of the nitrous oxide was consumed in 150 hours in reactions conducted between $60^{\circ} \mathrm{C}$ and $150^{\circ} \mathrm{C}$ that produced nitrogen and ammonia as the principal gaseous products along with small amounts of oxygen.

The radiolytic reaction also was investigated over a large temperature range. Hydrogen doubled the rate of decomposition of nitrous oxide in the absence of the simulated waste. However, when the reactions were conduced in the presence of dry and moist wastes, hydrogen did not enhance the rate of decomposition of nitrous oxide. The disappearance of the original gases and the formation of nitrogen are compatible with the formulation of a simple reaction:

$$
\mathrm{N}_{2} \mathrm{O}+\mathrm{H}_{2} \rightarrow \mathrm{N}_{2}+\mathrm{H}_{2} \mathrm{O}
$$




\section{RPP-6664 REV 0}

The $G$ values for the decomposition of hydrogen and nitrous oxide and the formation of nitrogen, oxygen, and ammonia are shown in Figure 4-5. The experimental $\mathrm{G}$ values for hydrogen and nitrous oxide shown in Figure 4-5 were used to estimate the consumption of nitrous oxide by radiation. The calculation indicated approximately $2.2 \%$ of the available nitrous oxide in a mixture containing $30 \%$ nitrogen, $30 \%$ hydrogen, $30 \%$ nitrous oxide, and $10 \%$ ammonia would be consumed in 1 year at a dose rate of $1,000 \mathrm{R} / \mathrm{h}$. Although the reaction rate is slow, the decomposition reaction of nitrous oxide could alter the composition of the mixture of gases that had been retained in the waste for decades.

The formation of ammonia from its elements and its rate of decomposition also were investigated in the gas phase and in the presence of simulated waste. Only traces of ammonia were detected in thermal reactions of a mixture containing $5 \%$ hydrogen and $95 \%$ nitrogen at $150{ }^{\circ} \mathrm{C}$ in the presence of the simulant. The synthesis of ammonia from these elements, which requires very specific catalysts and occurs at high pressures and temperatures (Thomas and Thomas 1969; Bottomley and Burns 1979), does not take place in the environment of waste.

The radiolytic experiments revealed that ammonia was formed from the elements but that the $G$ value decreased with total dose, as shown in Figure 4-6. The observations presented in this figure are in good agreement with previous findings indicating that ammonia is formed radiolytically from the elements but also decomposes to them even more rapidly (Spinks and Woods 1990).

Bryan and Pederson (1995) investigated the thermal and radiolytic decomposition of ammonia in the presence of waste simulants. The amount of nitrogen found in the experiments implied that about $10 \%$ of the original ammonia decomposed at $60^{\circ} \mathrm{C}$ in 150 hours. The observed decomposition rate is orders of magnitude greater than the rate anticipated for a thermal reaction, indicating the involvement of the components of the simulant or catalysis by the walls of the vessel.

The radiolytic decomposition reaction of ammonia is temperature dependent (Spinks and Woods 1990; Bryan and Pederson 1995) and is more rapid in the presence of moist simulant. At $60{ }^{\circ} \mathrm{C}, \mathrm{G}\left(-\mathrm{NH}_{3}\right)$ is 6.4 molecules $/ 100 \mathrm{eV}$ for dry simulant and 15.2 molecules $/ 100 \mathrm{eV}$ for moist simulant. The $\mathrm{G}$ value observed for the dry simulant is comparable to the $\mathrm{G}$ value observed for the reaction in the gas phase by Sorokin and Pshezhetskii (1964). The $G$ value may be enhanced in the moist simulant by reactions in the liquid phase (Pederson and Bryan 1996).

Clearly, the observed ammonia yields represent a balance between ammonia formation, for which $\mathrm{G}\left(\mathrm{NH}_{3}\right)$ ranges from 0.7 to 1.5 molecules $/ 100 \mathrm{eV}$, and its decomposition to hydrogen and nitrogen, for which $\mathrm{G}\left(-\mathrm{NH}_{3}\right)$ ranges from 6.3 to 15.2 molecules $/ 100 \mathrm{eV}$. The application of this finding suggests that, on balance, $0.2 \%$ to $0.4 \%$ of the retained ammonia in tank 241-SY-101 would be consumed in 1 year for a radiation dose of $1,000 \mathrm{R} / \mathrm{h}$. 
Figure 4-5. Generation Efficiency Values for the Decomposition of Nitrous Oxide and Hydrogen and Product Formation at Temperatures Ranging from $60^{\circ} \mathrm{C}$ to $150^{\circ} \mathrm{C}$.

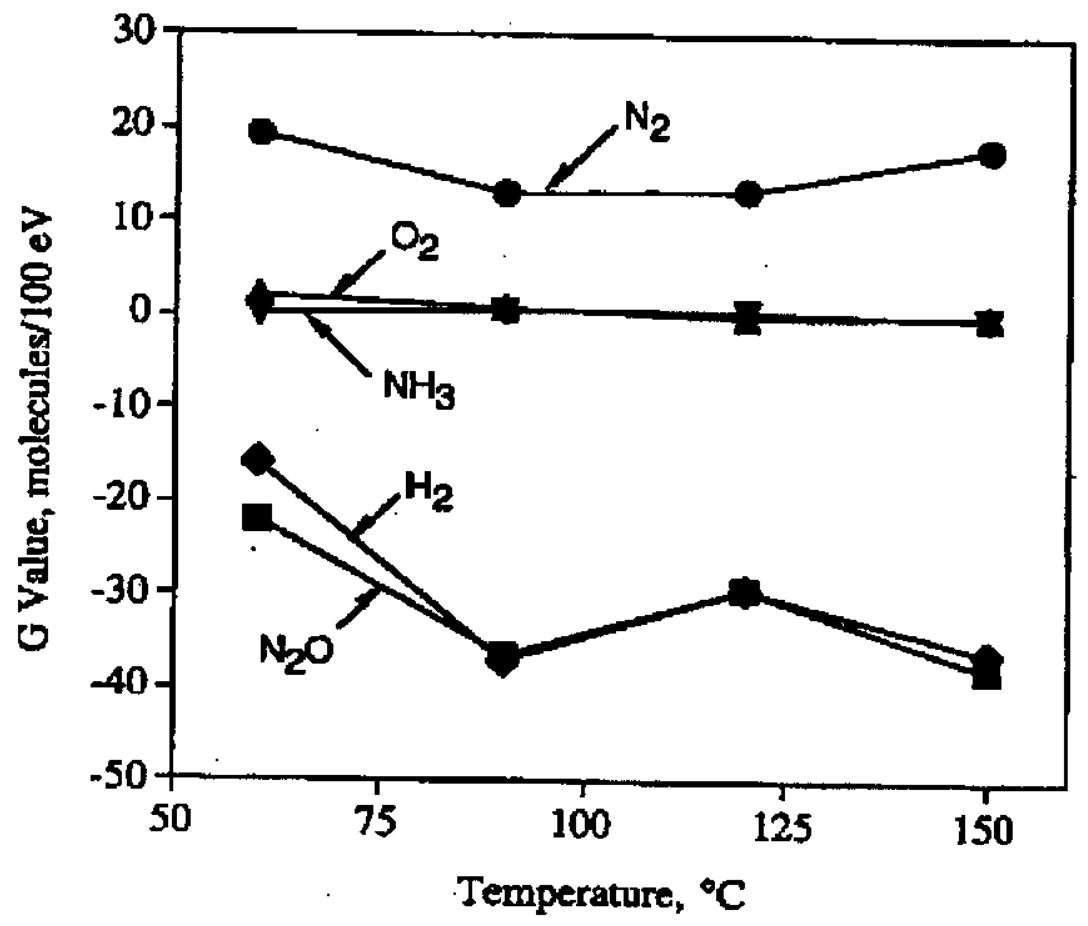

Figure 4-6. The Relationship between the Generation Efficiency of Ammonia and the Total Dose for the Formation of Ammonia from Hydrogen and Nitrogen at $90^{\circ} \mathrm{C}$.

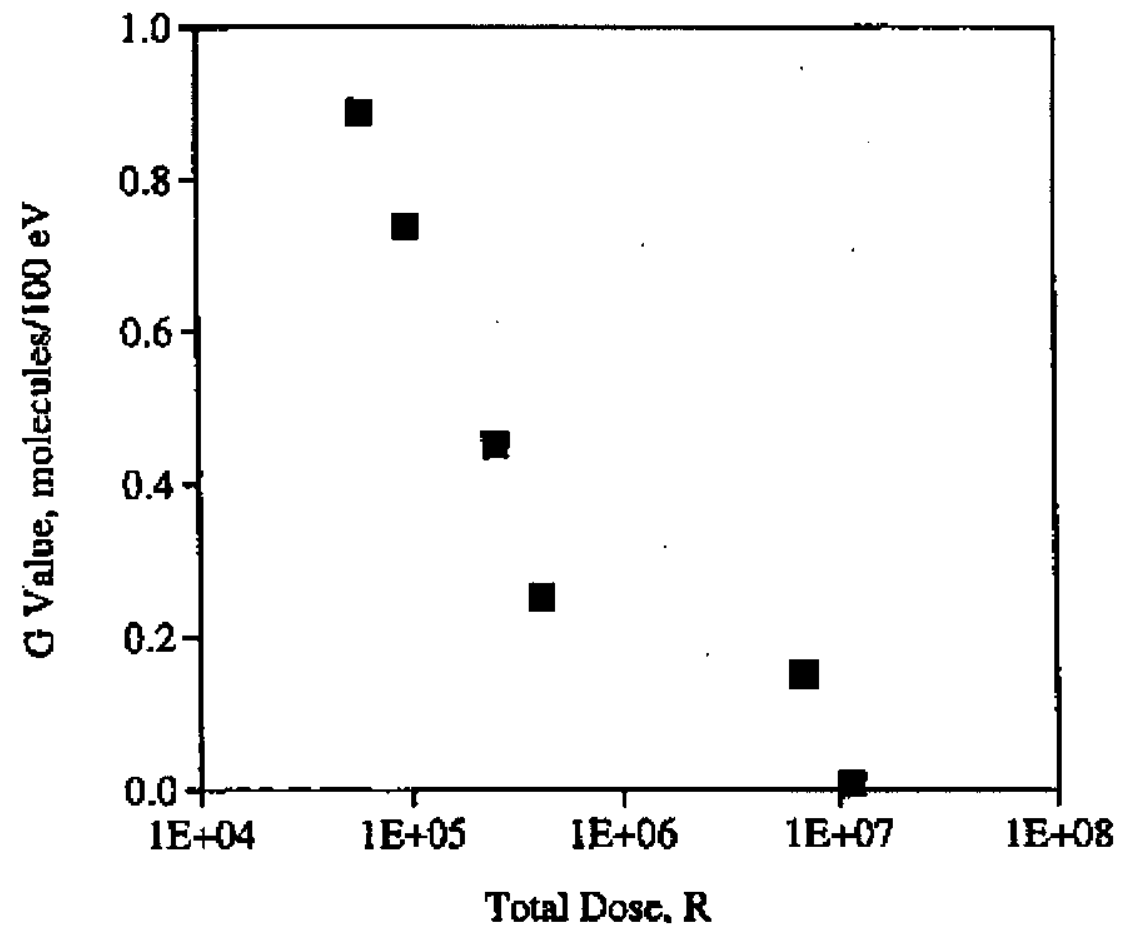




\section{RPP-6664 REV 0}

The laboratory work implies that the thermal and radiolytic decomposition reactions of nitrous oxide and ammonia in the gas phase are very slow. However, the work also suggests that the radiolysis of ammonia occurs at a somewhat more rapid rate in liquid waste simulants. Inasmuch as nitrous oxide and ammonia both are soluble in water and especially because ammonia is so abundant, even very slow reactions of these compounds may alter the composition of gaseous mixtures that have been retained for many years. Although the available evidence is not definitive, it is intriguing that the gases retained in nonconvective wastes for many years, as tabulated in Section 4.8, have high hydrogen-to-nitrous oxide ratios and their hydrogen-to-nitrogen ratios approach the three-to-one ratio in ammonia.

In summary, the thermolytic and radiolytic decomposition reactions of retained gases are slow. The reactions do not appear to influence the gas composition in convective waste where the rates of gas formation and release occur more rapidly. However, when the retained gas concentration is high and the gas is retained in the waste for years, as they are in many nonconvective wastes, the slow reactions of nitrogen, nitrous oxide, and ammonia may alter the gas composition.

\subsection{SOLUBILITY OF GASES}

The complexity of the waste and its high salt concentrations obviate the confident use of conventional physical models for the prediction of gas solubility. Consequently, empirical investigations of gas solubility were undertaken in 1994 and 1995 to assess the solubility of ammonia, oxygen, hydrogen, nitrogen, nitrous oxide, and methane in simulated waste mixtures (Norton and Pederson 1994, 1995), and studies of the solubility of ammonia have continued (Hedengren et al. 2000). The experimental results obtained in these investigations have been employed in conjunction with the Schumpe ion interaction model (Hermann et al. 1995; Hedengren et al. 2000) to estimate gas solubility in the liquid phases of the waste (Reynolds 1992; Mahoney et al. 1999).

The necessary Henry's Law constants, $K_{H}$, are defined by the following equation:

$$
\mathrm{K}_{\mathrm{H}}=\mathrm{m}_{\mathrm{i}} / \mathrm{P}_{\mathrm{i}}
$$

where $m_{i}$ is the concentration of a gas dissolved in the liquid phase in moles per kilogram of solvent, and $P_{i}$ is the partial pressure of the gas in atmospheres. Table 4-12 provides a comparison of the Henry's Law constants for pure water and the Henry's Law constants that were evaluated for the waste that was in tank 241-SY-101 in 1994 using measurements of simulants. 
Table 4-12. Henry's Law Constants Appropriate for Gases in the Liquid Phase of Tank 241-SY-101 Based on Experimental Measurements with Simulants and the Schumpe Model.

\begin{tabular}{|c|c|c|c|c|c|c|}
\hline \multirow{2}{*}{$\begin{array}{l}\text { Temp } \\
\text { (C) }\end{array}$} & \multicolumn{6}{|c|}{$\begin{array}{l}\text { Henry's Law Constant } \\
\text { (mol/kg water-atm) }\end{array}$} \\
\hline & Oxygen & Nitrogen & Hydrogen & Methane & $\begin{array}{l}\text { Nitrous } \\
\text { Oxide }\end{array}$ & Ammonia \\
\hline \multicolumn{7}{|c|}{ For Water" } \\
\hline 25 & $1.3 \mathrm{E}-03$ & $6.5 \mathrm{E}-04$ & $7.8 \mathrm{E}-04$ & $1.4 \mathrm{E}-03$ & $2.5 \mathrm{E}-02$ & 27 \\
\hline \multicolumn{7}{|c|}{ For Waste } \\
\hline 20 & $1.5 \mathrm{E}-05$ & $4.8 \mathrm{E}-06$ & $2.3 \mathrm{E}-05$ & $6.3 \mathrm{E}-06$ & $5.8 \mathrm{E}-04$ & 1.1 \\
\hline 35 & $1.2 \mathrm{E}-05$ & $3.9 \mathrm{E}-06$ & $2.2 \mathrm{E}-05$ & $4.9 \mathrm{E}-06$ & $3.9 \mathrm{E}-04$ & 5.7 \\
\hline 50 & $1.0 \mathrm{E}-05$ & $3.5 \mathrm{E}-06$ & $2.1 \mathrm{E}-05$ & $4.2 \mathrm{E}-06$ & $2.8 \mathrm{E}-04$ & 3.2 \\
\hline
\end{tabular}

Note: Information in this table is from:

- Norton, J. D., and L. R. Pederson, 1994, Ammonia in Simulated Hanford Double-Shell Tank Wastes: Solubility and Effects on Surface Tension, PNL-10173, Pacific Northwest Laboratory, Richland, Washington.

- Norton, J. D., and L. R. Pederson, 1995, Solubilities of Gases in Simulated Tank 241-SY-10I Wastes, PNL-10785, Pacific Northwest Laboratory, Richland, Washington.

*Information for water added.

These constants illustrate the general trends in solubility. The solubility of methane is depressed by a factor of more than 1,000 , and the solubility of oxygen, nitrogen, and nitrous oxide are depressed about 100 -fold. The solubility of hydrogen and ammonia are less impacted by salts, therefore their Henry' Law constants are only about five times smaller than the values in pure water. Recent measurements of ammonia solubility in high concentration salt simulants have been reported (Hedengren et al. 2000). These variations are the consequence of chemical interactions between gases and water in the presence and absence of the ionic atmosphere. Nitrous oxide is the most soluble permanent gas in the waste. It is about 20 times more soluble than hydrogen and about 100 times more soluble than nitrogen. Hydrogen is about five times more soluble than nitrogen. Methane, which is the most soluble organic hydrocarbon is about as soluble as diatomic nitrogen gas.

The practical application of Henry's law requires that each Henry's Law constant be evaluated for each waste type on the basis of the chemical composition and temperature. Mahoney et al. (2000) have acknowledged the uncertainty in the approach and have used the methodology to estimate a low and a high value for the amount of dissolved gas in the different layers of waste that were examined during the Retained Gas Sampling Program. The results are summarized in Table 4-13. 


\section{RPP-6664 REV 0}

The total quantity of each permanent gas in the convective and supernatant layers is small, usually less than $1 \%$ of the volume of the layer. The high and low solubility limits projected for nitrous oxide generally exceed the total quantity of this gas in the convective layer and establish that most of this gas is in solution. Hydrogen and nitrogen are much less soluble than nitrous oxide. The liquid layers are presumably saturated with these gases and the low and high solubility limits suggest between $1 \%$ and $10 \%$ of the total amount of each of these gases is in solution.

The total amount of gas in the nonconvective layers is much greater than the amount in the convective layer. Inasmuch as there is less liquid available for the dissolution of the gas, much less gas is in solution, and the fraction of the gas in solution is far smaller than in the convective layer. The amounts of hydrogen and nitrogen that are in solution in the nonconvective layers range from about 0.01 to 0.001 of the total amount of each gas. However, about $10 \%$ to $20 \%$ of nitrous oxide is found in the liquid phase of the nonconvective layer.

Few crusts have been investigated. The limited results imply that the gases in the crust are distributed in much the same manner as in the nonconvective layer with nitrous oxide distributed between the liquid and solid phases and nitrogen and hydrogen predominantly in the gaseous state.

Gas solubility plays an important role in determining the way in which the several gases are stored within the waste, the absolute and relative rates of their migration through the different layers, and the ongoing chemical reactions that can change the composition of the gas. In particular the relatively high solubility of nitrous oxide in the liquid phases of the waste allows this gas to accumulate in convective liquid phases and provides a pathway for the migration of this substance through the wet wastes that is not available for the migration of hydrogen and nitrogen. The differences in the hydrogen-to-nitrous oxide ratios for the retained gases from the convective and nonconvective portions of the waste are compatible with greater mobility of nitrous oxide. 


\section{RPP-6664 REV 0}

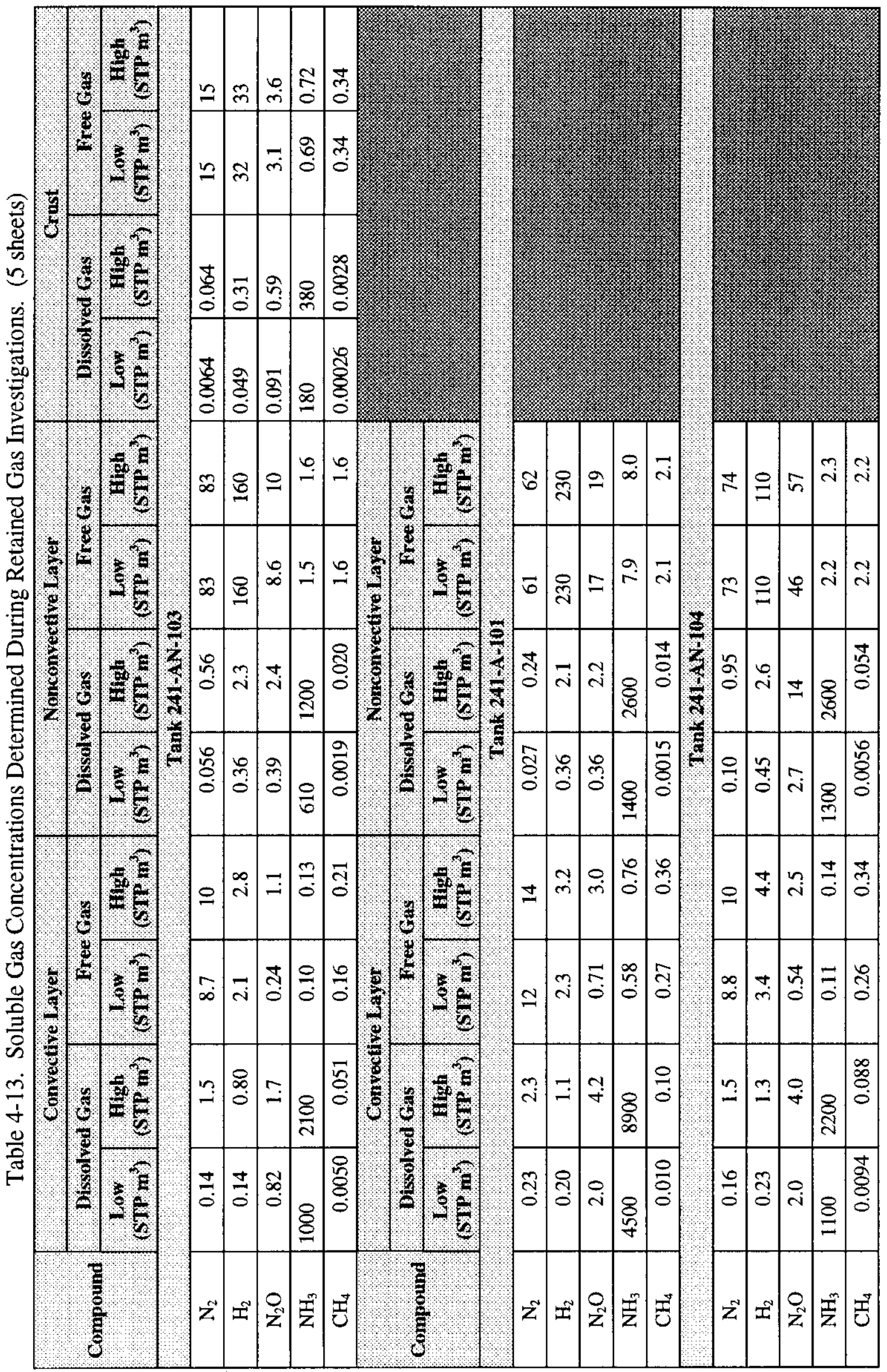


RPP-6664 REV 0

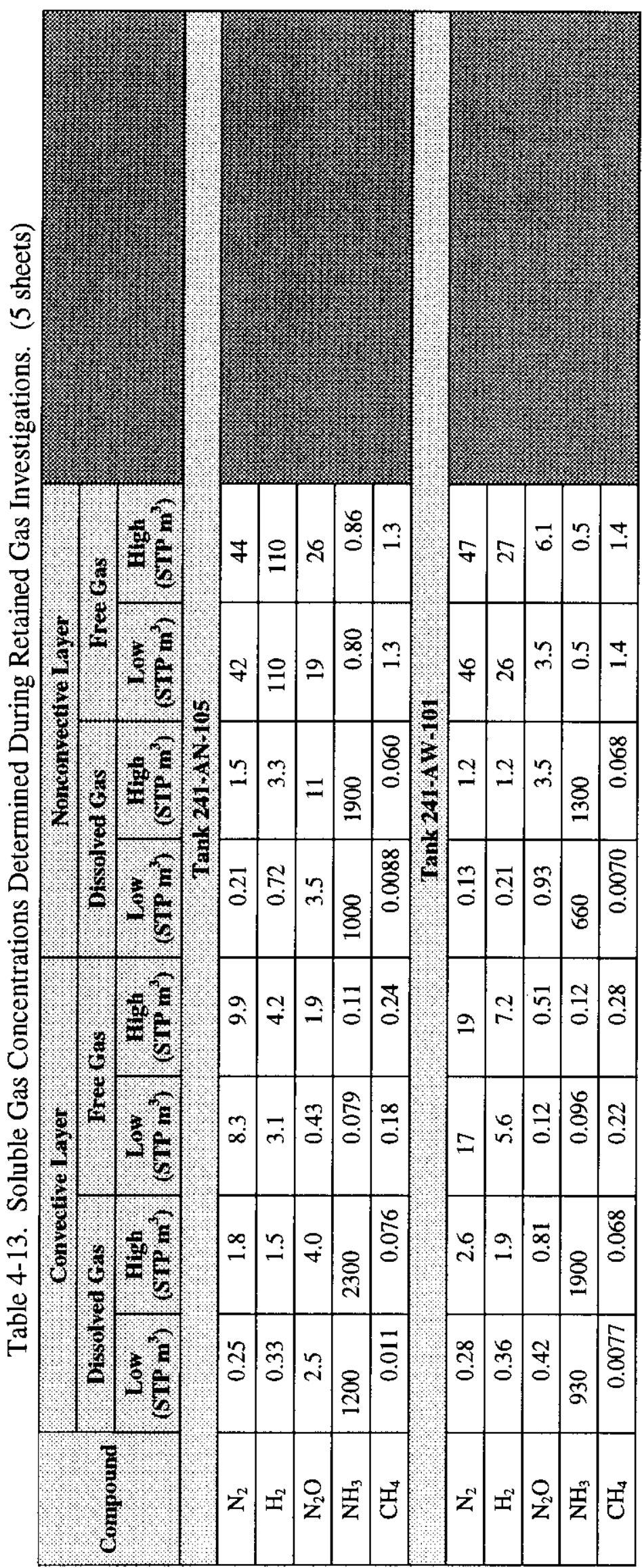




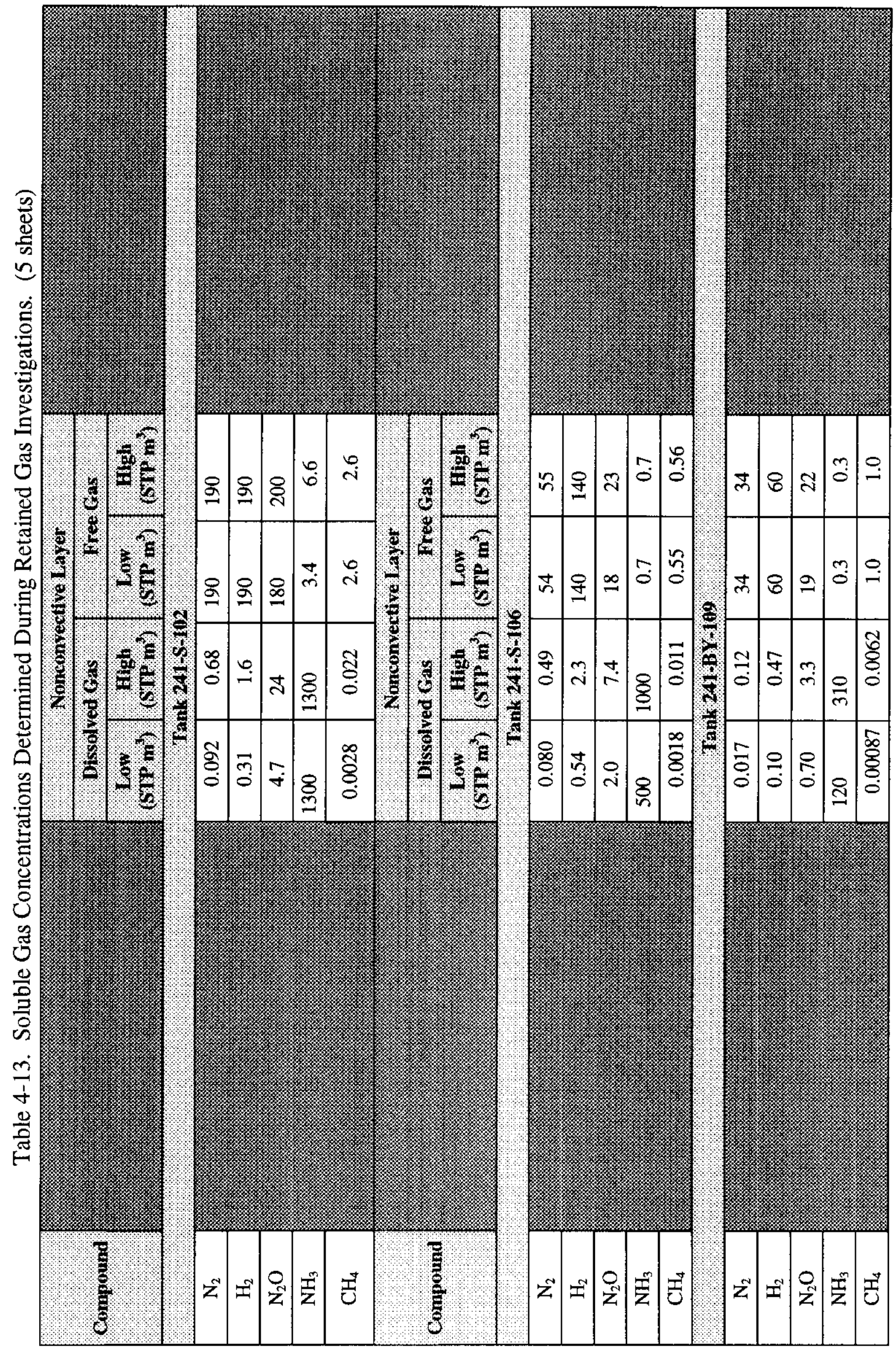




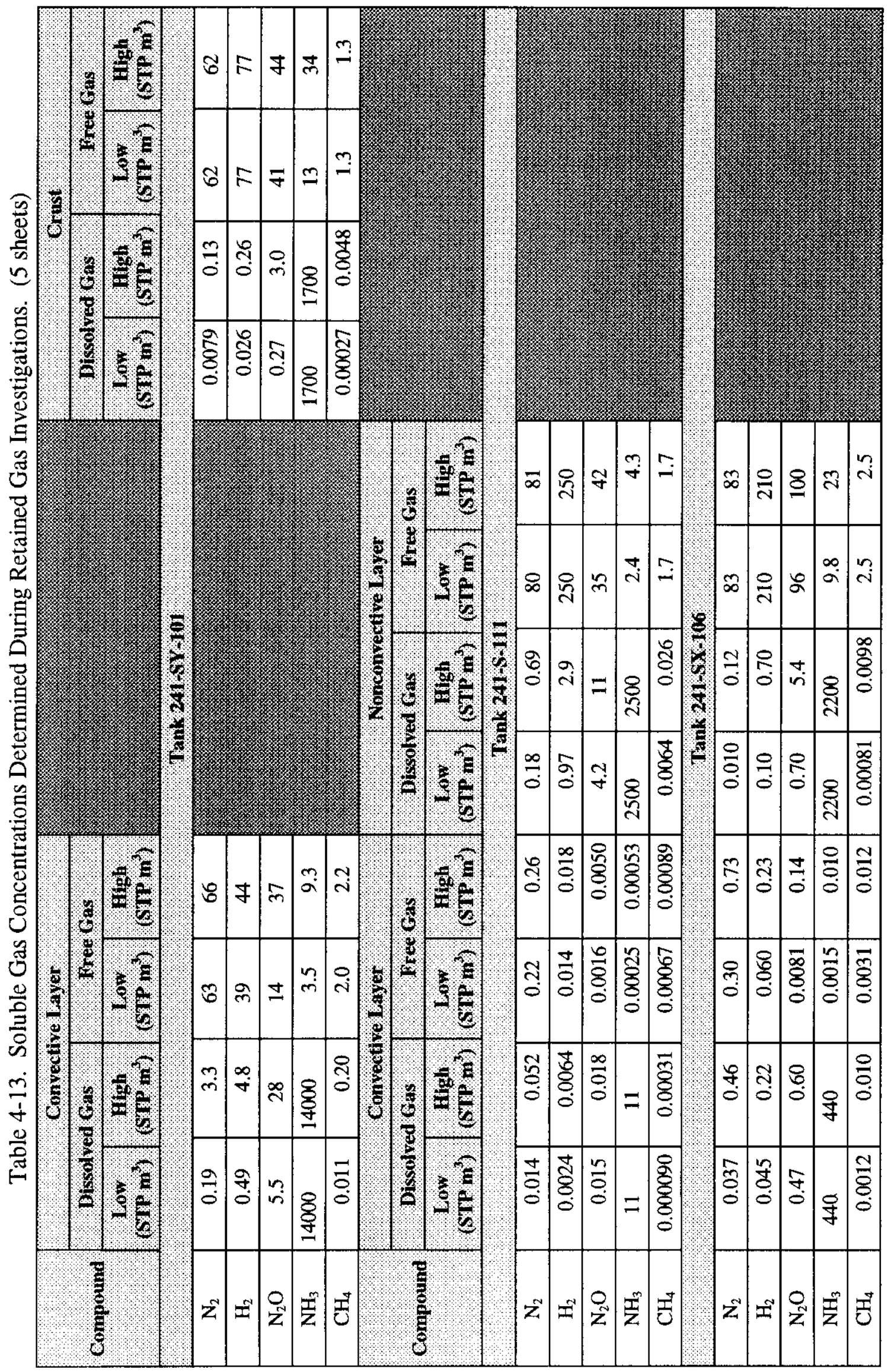


RPP-6664 REV 0

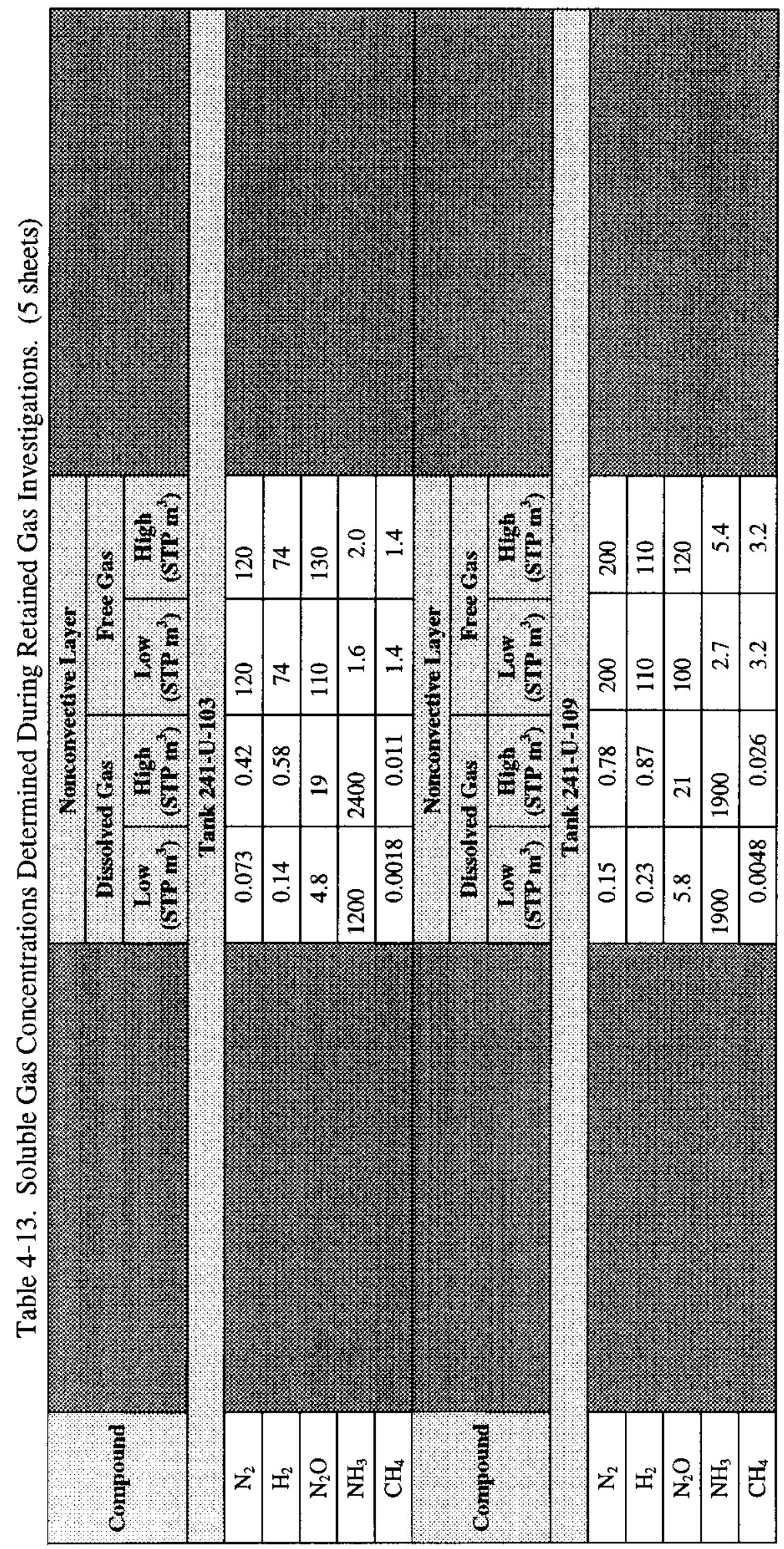


RPP-6664 REV 0

This page intentionally left blank. 
RPP-6664 REV 0

\subsection{MODELS FOR GAS GENERATION}

Several investigators (Hopkins 1994, 1995; Graves 1994; Pederson and Bryan 1996; Hu 1997, 2000) have developed empirical models to estimate the hydrogen generation rate from tank wastes as a function of temperature and waste composition. The models have been systematically improved by the investigators as the quality and quantity of the technical information discussed in the previous sections has become available. For example, the necessary kinetic gas generation parameters used in the most recent models were determined by Person, Bryan, King, and Pederson in laboratory tests with waste samples. This information was not available when the reports by Hopkins $(1994,1995)$ and Graves (1994) were prepared. Although the essential concepts have not changed, laboratory work differentiating the radiolytic and thermal rates, elaborating the chemical origins of the gas, and establishing the concentration dependencies and reactivity patterns of the organic molecules has provided a much better basis for the development of predictive models for hydrogen generation than was available when the first models were presented. $\mathrm{Hu}(2000)$ employed this information and devised a general model for the calculation of hydrogen generation rates. This model, which is discussed in Section 5.3, provides hydrogen generation rates that are generally within a factor of 2.5 of the rates observed in the field.

The technical basis for the current model is described chronologically. The early models are briefly presented in Section 5.1, and the more general, current model is described in Section 5.2.

\subsection{PRELIMINARY ASSESSMENTS OF HYDROGEN GENERATION RATE}

Hopkins (1994, 1995), Graves (1994), and Pederson and Bryan (1996) have described empirical models for the calculation of the hydrogen generation rates. The early models are based on the concept that the observed hydrogen generation rate in one tank together with information about the total organic content of the waste, its temperature, and other related observations can be used to calculate the hydrogen generation rate for another configuration of the waste in a different tank.

\subsubsection{Thermal Generation Rates}

Hopkins (1994) used the hydrogen generation rate observed for the waste in tank 241-SY-101 as a reference point. He adopted the concept that the thermal rate of hydrogen generation depended upon the total organic and aluminum content of the waste. Differences in waste temperature were accounted for using Equation 5.1 if the waste was cooler than that in tank 241-SY-101 and Equation 5.2 if the waste was warmer:

$$
\begin{gathered}
\mathrm{r}_{\mathrm{t}, \mathrm{X}}=\mathrm{r}_{\mathrm{t}, \mathrm{SY}-101}\left([\mathrm{TOC}]_{\mathrm{X}}[\mathrm{Al}]_{\mathrm{X}}\right) /\left([\mathrm{TOC}]_{\mathrm{SY}-101}[\mathrm{Al}]_{\mathrm{SY}-101}\right) \times \exp \left\{-26.0\left(1 / \mathrm{T}_{\mathrm{X}}-1 / \mathrm{T}_{\mathrm{SY}-101}\right)\right\} \\
\text { for } \mathrm{T}_{\mathrm{X}}<320 \mathrm{~K}
\end{gathered}
$$




$$
\begin{aligned}
& \mathrm{r}_{\mathrm{t}, \mathrm{X}}=\mathrm{r}_{\mathrm{t}, \mathrm{SY}-101}\left([\mathrm{TOC}]_{\mathrm{X}}[\mathrm{Al}]_{\mathrm{X}}\right) /\left([\mathrm{TOC}]_{\mathrm{SY}-101}[\mathrm{Al}]_{\mathrm{SY}-101}\right) \times \exp \left\{-90.0\left(1 / \mathrm{T}_{\mathrm{X}}-1 / \mathrm{T}_{\mathrm{SY}-101}\right)\right\} \\
& \text { for } \mathrm{T}_{\mathrm{X}}>320 \mathrm{~K}
\end{aligned}
$$

where $r_{t}$ is the rate for thermal generation of hydrogen per unit waste, " $X$ " is the waste for which the rate is being calculated, SY-101 is the known rate for tank 241-SY-101, [TOC] and [Al] are the TOC and aluminum contents of the waste in weight percent, and $\mathrm{T}$ is the absolute temperature in degrees kelvin.

An activation energy of $26 \mathrm{~kJ} / \mathrm{mol}$ was used for estimating generation rates at temperatures less than $47^{\circ} \mathrm{C}(320 \mathrm{~K})$, which is the temperature of the waste in tank $241-\mathrm{SY}-101$. The low activation energy, while much smaller than the values observed in any laboratory tests with either simulated or actual wastes, was selected to provide conservatism (Hopkins 1994). The hydrogen generation rate in tank 241-SY-101 was given by Hopkins (1994) as $2.37 \times 10^{-4} \mathrm{ft}^{3}$ hydrogen per $\mathrm{ft}^{3}$ of waste per day $\left(5.76 \times 10^{-9}\right.$ mole hydrogen per liter waste per minute, or $5.27 \times 10^{-6}$ moles hydrogen per kilogram of waste per day), assuming a waste density of $1.59 \mathrm{~g} / \mathrm{cm}^{3}$.

Graves (1994) adopted the hydrogen generation rate reported by Meisel et al. (1993) for a simulant containing water, sodium nitrite, sodium nitrate, sodium aluminate, sodium hydroxide, $0.065 M$ EDTA, $0.65 M$ HEDTA, and $0.10 M$ sodium citrate (simulant POI) at $90^{\circ} \mathrm{C}$. The simulant is identical to simulant SY1-SIM used by Bryan and Pederson (1994) and virtually identical to simulant SY1-SIM-91B-NC used at the Georgia Institute of Technology. The model used by Graves (1994) depended on the organic content of the waste but did not include the aluminum concentration. The concept that gas generation occurred predominantly in the liquid portion of the waste was explicitly included. An Arrhenius expression with an activation energy of $40.9 \mathrm{~kJ} / \mathrm{mol}$, the activation energy reported by Meisel et al. (1993) for hydrogen generation by glycolate ion, was used to describe the temperature dependence, as shown in Equation 5.3:

$$
\mathrm{r}_{\mathrm{t}, \mathrm{X}}=\mathrm{r}_{\mathrm{t}, \mathrm{POI}}\left([\mathrm{TOC}]_{\mathrm{X}} \alpha_{\mathrm{L}, \mathrm{X}}\right) /\left([\mathrm{TOC}]_{\mathrm{POI}} \alpha_{\mathrm{L}, \mathrm{POI}}\right) \mathrm{x} \exp \left\{-40.9\left(1 / \mathrm{T}_{\mathrm{X}}-1 / \mathrm{T}_{\mathrm{SY}-101}\right)\right\}
$$

where $r_{t}$, is the rate for thermal generation of hydrogen per unit waste, " $\mathrm{X}$ " is the waste for which the rate is being calculated, $\mathrm{POI}$ is the known rate for simulant POI, [TOC] is the TOC in weight percent, $\alpha_{\mathrm{L}}$ is the volume percent liquid in the waste, which was taken to be $100 \%$ for the simulant, and $\mathrm{T}$ is the absolute temperature of the waste in degrees kelvin.

The hydrogen generation rate determined by Meisel et al. (1993) for simulant POI at $60{ }^{\circ} \mathrm{C}$ is $8.3 \times 10^{-9}$ moles per minute per liter based upon a density of $1.2 \mathrm{~g} / \mathrm{cm}^{3}$.

Pederson and Bryan (1996) used kinetic parameters obtained in laboratory tests with waste samples from tank 241-SY-103 as a basis for estimating generation rates for other tanks. They obtained very good agreement between estimated hydrogen generation rates and the field observations reported by Wilkins (1995). A modified expression for estimating the thermal component of hydrogen generation based these observations and the results for tank 241-SY-103 is given in Equation 5.4:

$$
\mathrm{r}_{\mathrm{t}, \mathrm{X}}=\mathrm{r}_{\mathrm{t}, \mathrm{SY}-103}\left([\mathrm{TOC}]_{\mathrm{X}}[\mathrm{Al}]_{\mathrm{X}}\right) /\left([\mathrm{TOC}]_{\mathrm{SY}-103}[\mathrm{Al}]_{\mathrm{SY}-103}\right) \times \exp \left\{-91.0\left(1 / \mathrm{T}_{\mathrm{X}}-1 / \mathrm{T}_{\mathrm{SY}-103}\right)\right\}
$$


where $r_{t}$ is the rate for thermal generation of hydrogen per unit waste, "X" is the waste for which the rate is being calculated, SY-103 is the known rate for tank 241-SY-103, [TOC] and [Al] are the TOC and aluminum concentrations in weight percent for the waste and tank 241-SY-103, and $T$ is the absolute temperature of the waste in degrees kelvin.

This rate expression is identical in form to the rate expression proposed by Hopkins $(1994,1995)$ except for the use of tank 241-SY-103 waste rather than tank 241-SY-101 waste as the reference point. The thermally activated hydrogen generation rate for tank $241-S Y-103$ was measured by Bryan et al. (1996) to be $3.5 \times 10^{-7} \mathrm{~mol} / \mathrm{kg}$-day at $31.7^{\circ} \mathrm{C}$. The concentrations of TOC and aluminate ion in the convective layer are 0.74 weight percent and 2.8 weight percent, respectively (Wilkins 1995). Pederson and Bryan (1996) and Hu (1997) tested this model for gas generation. They found that the predicted thermal hydrogen generation rates were within a factor of three of the rates observed in laboratory tests.

\subsubsection{Radiolytic Rates}

Hopkins $(1994,1995)$ and Graves (1994) based their estimate of the radiolytic hydrogen generation rate on the results of Meisel et al. (1991a, 1991b, 1993), who found that the hydrogen yield increased approximately linearly with the concentration of carbon-hydrogen and nitrogenhydrogen bonds in work with simulants. The relationship is shown in Equation 5.5:

$$
\mathrm{G}\left(\mathrm{H}_{2}\right)=0.031+0.013 \mathrm{n}_{(\mathrm{CH}+\mathrm{NH})}[\text { complexant concentration] }
$$

where $\mathrm{n}_{(\mathrm{CH}+\mathrm{NH})}$ is the sum of the carbon-hydrogen and nitrogen-hydrogen bonds in the molecule and the complexant concentration is given in moles per liter. This relationship has been employed in the models describing the generation of hydrogen in the Hanford Site waste.

Hopkins $(1994,1995)$ estimated the radiolytic $\mathrm{G}$ value for tank $241-\mathrm{SY}-101$ to be 0.100 molecules $/ 100 \mathrm{eV}$. Graves (1994) arrived at a similar G value, 0.0977 molecules/100 eV. These apparent $\mathrm{G}$ values were based upon the cesium and strontium contents and the observed hydrogen generation rate. It is pertinent that these values are about twice the value implied by Equation 5.4 for tank 241-SY-101 waste under the assumption that all the organic carbon in the tank is present in HEDTA. Difficulties of this kind prompted additional laboratory and field work to better establish the factors governing hydrogen generation and led to the investigations of gas generation in different tank wastes.

Bryan et al. (1996) determined $\mathrm{G}\left(\mathrm{H}_{2}\right)$ was $0.14 \pm 0.02$ molecules/100 eV for the convective layer of tank 241-SY-103. The organic molecules in this liquid layer are complexants and their soluble remnants, and the TOC is $0.74 \mathrm{wt} \%$ (Campbell et al. 1996a, 1996b). The hydrogen yield due to radiolytic reactions involving organic solutes can be estimated by subtracting the $\mathrm{G}\left(\mathrm{H}_{2}\right)$ value for radiolysis of a simulated waste containing no organic solutes $(0.031$ molecules $/ 100 \mathrm{eV})$ from the total $\mathrm{G}\left(\mathrm{H}_{2}\right)$ value for the waste $(0.14 \pm 0.02$ molecules $/ 100 \mathrm{eV})$, which yields 0.11 molecules of hydrogen per $100 \mathrm{eV}$. Normalizing to the organic carbon content, the radiolytic yield of hydrogen from an organic source is $0.11 / 0.74$, or $0.15 \pm 0.05$ molecules of hydrogen per $100 \mathrm{eV}$ per gram TOC, assuming a $20 \%$ relative uncertainty in the TOC concentration. The chemical information and the empirical observations are consistent with the formula shown in 
Equation 5.6 for radiolytic hydrogen generation in a waste containing high concentrations of nitrate and nitrite ion and reactive organic compounds:

$$
\mathrm{G}\left(\mathrm{H}_{2}\right)=0.031+0.15[\mathrm{TOC}]
$$

The hydrogen production rate predicted by Equation 5.6 requires information about the concentrations of reactive organic molecules. The concentrations of the reactive organic molecules (i.e., EDTA, HEDTA) are not usually available. However, the necessary reactive carbon concentrations can be estimated from the difference between the measured TOC content and the oxalate ion content. Pederson and Bryan (1996) and $\mathrm{Hu}(1997)$ used this approach to calculate the radiolytic rates of hydrogen generation observed in laboratory experiments. They found the calculated rates were within a factor of three of the observed rates.

\subsection{CURRENT ASSESSMENTS OF HYDROGEN GENERATION RATE}

The approaches used by Hopkins (1994), Graves (1994), and Pederson and Bryan (1996) laid the basis for the more recent, more general, empirical model advanced by $\mathrm{Hu}(2000)$. The earlier models were based on the concept that the results for one simulant or one tank could be used as a basis for the prediction of the hydrogen generation rates for many other tanks. Hu (2000) sought a more general approach that excluded the dependence on the rate data for a single tank or simulant and reevaluated the factors governing the thermal and radiolytic generation of hydrogen. Although the agreement between the predicted and observed rates is only modestly better than was realized in the prior work, the new approach is more complete and more general. The development of the terms for the empirical estimation of hydrogen generation by thermal chemical reactions, radiolytic processes, and corrosion are discussed in Sections 5.2.1, 5.2.2 and 5.2.3. The application of the model to tank waste is presented in Section 5.3.

\subsubsection{Thermal Generation Rates}

The information presented in the previous sections indicates the thermal rate of hydrogen generation depends on the product of an empirically determined constant, the concentrations of the organic constituents and the aluminate ion, and the exponential Arrhenius term, as outlined in Equation 5.7:

$$
\text { Rate }=\text { constant } \mathrm{x} \text { [organic compounds][aluminate ion }] \mathrm{x} \exp \left(-\mathrm{E}_{\mathrm{A}} / \mathrm{RT}\right)
$$

As discussed in previous sections, Delegard (1980), Ashby et al. (1994), Bryan and Pederson (1994), and others have found first-order kinetic dependencies of hydrogen generation on hydroxide, aluminate, nitrite, and organic solute concentrations in studies with simulated wastes. However, it would be inappropriate to employ the concentrations of these four constituents in rate equations because the concentration dependencies sometimes are applicable only for selected, sometime narrow, concentration ranges. For example, first-order dependence on the nitrite ion concentration holds for concentrations up to approximately $0.5 \mathrm{M}$; for higher concentrations, gas generation rates are essentially independent of changes in the nitrite ion concentration (Delegard 1980). Most Hanford Site waste mixtures contain well over 0.5M 
sodium nitrite, and the existing differences in the high nitrite ion concentrations would not alter the reaction rate. There are some notable exceptions: the calculation of the hydrogen generation rates for the wastes from tanks 241-T-104 and 241-T-110, which contain low concentrations of sodium nitrite and sodium nitrite, need to be addressed separately.

$\mathrm{Hu}(2000)$ reexamined the available information and reaffirmed the first-order dependence on the TOC content. The dependence on the aluminate ion content was less clear. However, Person (1996) had examined the relationship between the hydrogen generation rate and the concentration of possible reagents by diluting tank 241-SY-101 samples with sodium hydroxide solutions. The sodium hydroxide concentration of the diluent was chosen such that the sodium hydroxide concentration in the waste sample remained unchanged after dilution. Person (1996) found that dilution of core composite samples to $65 \%$ of the original concentration slowed the initial rate of gas generation to $52 \%$ of that determined for the undiluted sample. If the rate law had only one term with a first-order dependence, for example the organic carbon content, dilution to $65 \%$ of the original concentration should lower the gas generation rate to $65 \%$ of the rate for the undiluted sample. If the rate law exhibited first-order dependencies on the concentrations of two constituents, plausibly aluminate ion and TOC, the rate should decrease to $(0.65)^{2}$, or $42 \%$, of the rate for the undiluted sample. Similarly, for first-order dependencies on three constituents, the rate of gas generation should decrease to $(0.65)^{3}$, or $27 \%$, of the value for the undiluted waste. The finding that the rate decreased by $52 \%$ is most consistent with the hypothesis that thermal gas generation reaction rates depend on the concentrations of two components. Inasmuch as Delegard (1980) found gas generation rates to be insensitive to the nitrite ion concentration at the concentration of that component found in tank 241-SY-101, Person's (1996) investigation identifies soluble organic compounds and aluminate ions as components on which thermal gas generation rates directly depend. $\mathrm{Hu}(2000)$ exploited this information to reformulate Equation 5.7 to include a first-order dependence on TOC and a four-tenths-order dependence on the aluminum content to obtain Equation 5.8:

$$
\text { Rate }=\text { constant } \times \text { [organic compounds][aluminate ion] }{ }^{0.4} \times \exp -\mathrm{E}_{\mathrm{A}} / \mathrm{RT}
$$

The reactive organic complexants responsible for thermal hydrogen generation are very soluble in the aqueous phases of the waste (Barney 1995, 1996, 1997), and the reactions responsible for hydrogen generation therefore occur predominantly in the aqueous supernatant layer and in the aqueous portions of the saltcakes and sludges rather than in the solid phases. $\mathrm{Hu}(2000)$ calculated the rate of reaction in the aqueous portion of the solid and in the liquid supernatant by using the measured concentrations of the organic constituents and aluminate ion in these waste components and by estimating the liquid portion of the saltcakes and sludges from the measured water content.

The relationship between the thermal hydrogen generation rates measured in the laboratory and the concentrations of the organic compounds and aluminate ion in the liquid portion of the waste is shown in Figure 5-1. This figure shows the relationships that occur when the organic constituents are assigned a first-order dependence, aluminate ion is assigned a four-tenths-order dependence, and the reaction is presumed to occur exclusively in the liquid phase. Statistical analyses of the information ( $\mathrm{Hu} \mathrm{2000)} \mathrm{imply} \mathrm{that} \mathrm{the} \mathrm{excellent} \mathrm{relationship} \mathrm{is} \mathrm{realized} \mathrm{because}$ the reaction is presumed to occur exclusively in the liquid phase with a first order-dependence on the organic content rather than because the aluminate ion is assigned a fractional-order dependence. 


\section{RPP-6664 REV 0}

Figure 5-1. Relationship between the Rate for Hydrogen Generation and the Total Organic Carbon and Aluminate Ion Concentrations.

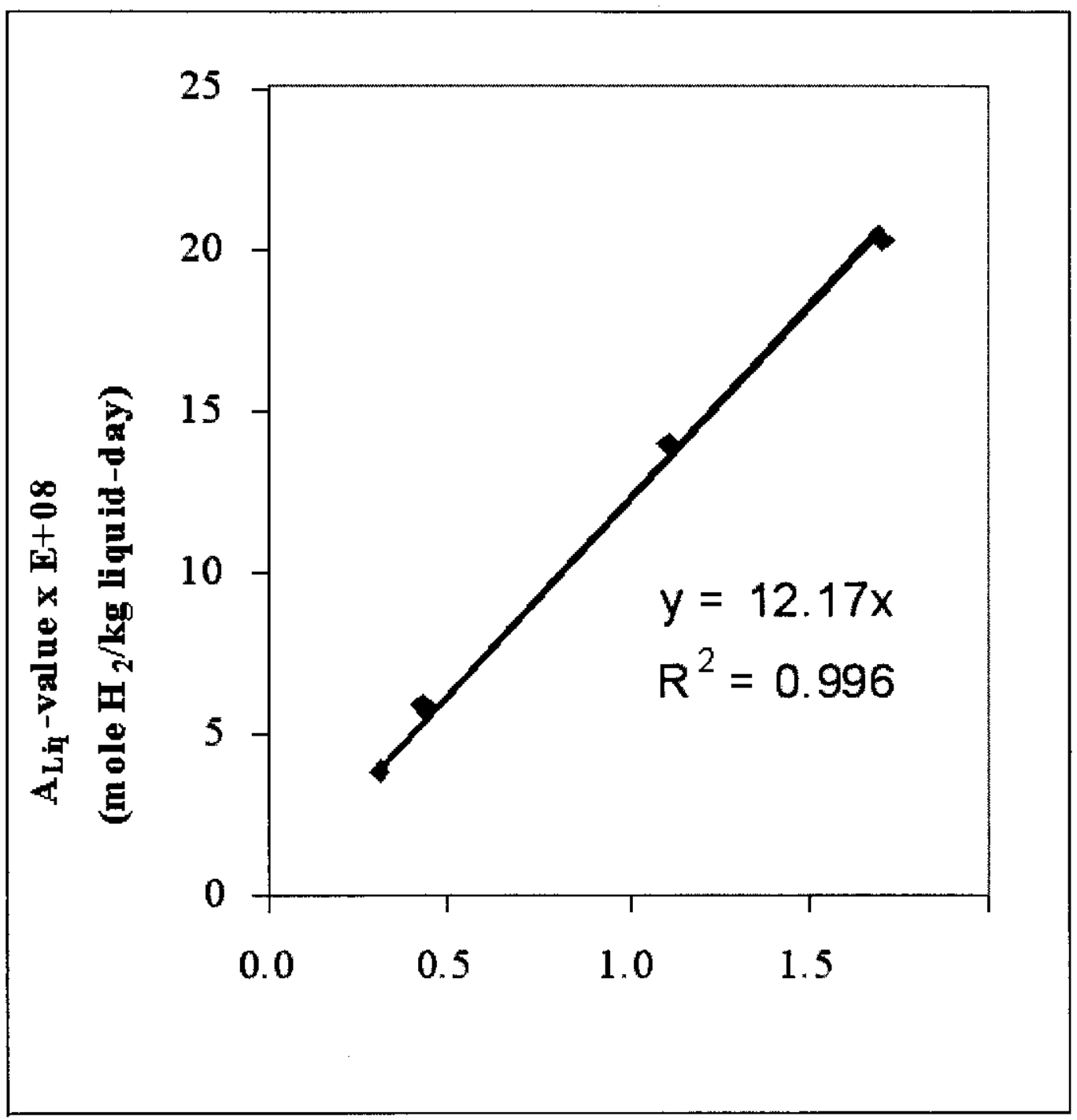

The hydrogen-generating capacity of a waste is not necessarily related to the TOC content because organic constituents in an aged waste containing appreciable amounts of oxalate ion are much less reactive than the organic contents of a less-aged waste with hydrogen-rich complexants. Inasmuch as the total organic content of the liquid is employed in the $\mathrm{Hu}(2000)$ analysis and sodium oxalate is essentially insoluble in the liquid, it is unnecessary to correct for the oxalate ion content. Not unexpectedly, $\mathrm{Hu}$ (2000) found that statistical treatments suggested that there were inherent differences in the reactivity of the organic compounds in different wastes and that this factor could be significant in determining the hydrogen generation rate. The organic reactivity ratio ranged from about 0.2 to 1.0 , with higher values for the wastes in double-shell tanks than for the wastes in single-shell tanks. This finding prompted the introduction of an organic reactivity factor, $\mathrm{r}_{\mathrm{f}}$. Statistical analyses indicated $\mathrm{r}_{\mathrm{f}}$ was 0.4 for single-shell tanks and 0.7 for double-shell tanks. 


\section{RPP-6664 REV 0}

The final equation for the empirical prediction of the thermal hydrogen generation rate is shown in Equation 5.9:

$$
\text { Thermal hydrogen generation rate }=a_{t h m} \times r_{f} \times[T O C][A l]^{0.4} \times L_{f} \exp \left(E_{\text {Athm }} / R T\right)
$$

where the thermal generation rate is given in moles of hydrogen generated per kilogram of waste per day, $\mathrm{a}_{\mathrm{thm}}$ is the empirically determined thermal generation rate $\left(2.76 \times 10^{-9} \mathrm{~mole} / \mathrm{kg}\right.$-day), $r_{f}$ is a factor adjusting for differences in organic reactivity $(0.4$ for single-shell tanks and 0.7 for double-shell tanks), [TOC] and [Al] are the measured organic and aluminum contents in weight percent in the liquid phase of the layer under consideration, $\mathrm{E}_{\mathrm{Athm}}$ is the measured thermal activation energy $(89.3 \mathrm{~kJ} / \mathrm{mole}), \mathrm{R}$ is the gas constant $(8.314 \mathrm{~J} / \mathrm{mole}-\mathrm{K})$, and $\mathrm{T}$ is the temperature in degrees kelvin.

In practical applications, the rates of hydrogen generation of the individual layers of waste are calculated and summed to provide the total thermal rate for the entire waste. Fortunately, the requisite information is available for many components of many wastes, so this empirical approach can be practically applied.

\subsubsection{Radiolytic Rates}

The chemistry governing radiolytic generation of hydrogen was discussed in Sections 2.0 and 3.0. In brief, hydrogen is produced by the radiolysis of water, the abstraction of hydrogen atoms from the organic constituents by hydrogen atoms, and by ionic chemical reactions of the organic intermediates produced during radiolysis. The rate of hydrogen generation by radiolysis is therefore the sum of the rates of these processes. The rates of the radiolytic reactions of water are temperature independent, but the rates of the ionic organic reactions are temperature dependent.

Since hydrogen generation occurs predominantly in the liquid phase, the radiolytic hydrogen generation rate for a waste is the product of the $\mathrm{G}\left(\mathrm{H}_{2}\right)$ value, the radiation dose, and the liquid fraction ( $\mathrm{Hu} 2000)$ :

$$
\text { Radiolytic generation rate }=\mathrm{C} \times \mathrm{G}\left(\mathrm{H}_{2}\right) \times \mathrm{H}_{\text {load }} \times \mathrm{L}_{\mathrm{f}}
$$

where the radiolytic generation rate is expressed in moles of hydrogen $/ \mathrm{kg}$-day, $\mathrm{C}$ is the unit conversion factor, $\mathrm{G}\left(\mathrm{H}_{2}\right)$ is the $\mathrm{G}$ value in molecules per $100 \mathrm{eV}, \mathrm{H}_{\text {load }}$ is the radiation dose in watts per day, and $\mathrm{L}_{\mathrm{f}}$ is the liquid fraction.

$\mathrm{G}\left(\mathrm{H}_{2}\right)$ is partitioned into two terms, one representing the radiolysis of water and the other representing the radiolysis of the organic constituents in Equation 5.11:

$$
\mathrm{G}\left(\mathrm{H}_{2}\right)=\mathrm{G}\left(\mathrm{H}_{2}\right)_{\mathrm{H} 2 \mathrm{O}}+\mathrm{G}\left(\mathrm{H}_{2}\right)_{\mathrm{ORG}}
$$

Tabata et al. (1991) pointed out that $\mathrm{G}\left(\mathrm{H}_{2}\right)_{\mathrm{H} 2 \mathrm{O}}$ for nitrite and nitrate brines is determined by Equation 5.12:

$$
\mathrm{G}\left(\mathrm{H}_{2}\right)_{\mathrm{H} 2 \mathrm{O}}=0.45-0.31\left[\mathrm{NO}_{2}^{-}\right]^{1 / 3}-0.41\left[\mathrm{NO}_{3}\right]^{1 / 3}
$$


where $\mathrm{G}$ is given in molecules/100 eV and $\left[\mathrm{NO}_{2}{ }^{-}\right]$and $\left[\mathrm{NO}_{3}{ }^{-}\right]$are the molar concentrations of nitrite and nitrate ions.

$\mathrm{Hu}(2000)$ found this formulation did not accurately predict the well-defined rate of hydrogen generation for tank 241-AY-102, for which the nitrite and nitrate concentrations are known and which has no organic material. Accordingly, $\mathrm{Hu}(2000)$ reevaluated the parameters in Equation 5.12 to provide Equation 5.13:

$$
\mathrm{G}\left(\mathrm{H}_{2}\right)_{\mathrm{H} 2 \mathrm{O}}=0.45-0.56\left[\mathrm{NO}_{2}{ }^{-1 / 3}-0.43\left[\mathrm{NO}_{3}{ }^{-1 / 3}\right.\right.
$$

where the symbols have the same meaning as for Equation 5.12. This formulation of the equation should be more applicable for estimating $\mathrm{G}\left(\mathrm{H}_{2}\right)_{\mathrm{H} 2 \mathrm{O}}$ for wastes at the Hanford Site. Statistical analyses showed that the most appropriate default value for $\mathrm{G}\left(\mathrm{H}_{2}\right)_{\mathrm{H} 2 \mathrm{O}}$ was 0.005 for situations in which the concentrations of sodium nitrite and sodium nitrate have not been measured but are known to be high.

The second term in Equation 5.11, $\mathrm{G}\left(\mathrm{H}_{2}\right)_{\mathrm{ORG}}$, accounts for the generation of hydrogen from organic compounds. Laboratory work indicates this $\mathrm{G}$ value is temperature dependent because the hydrogen is produced from the temperature-dependent reactions of organic intermediates. $\mathrm{Hu}$ (2000) formulated Equation 5.14 to model this component of hydrogen generation:

$$
\mathrm{G}\left(\mathrm{H}_{2}\right)_{\mathrm{ORG}}=\mathrm{a}_{\mathrm{rad}}[\mathrm{TOC}] \exp \left(-\mathrm{E}_{\text {Arad }} / \mathrm{RT}\right)
$$

where $\mathrm{a}_{\text {rad }}$ is expressed in molecules of hydrogen per $100 \mathrm{eV},[\mathrm{TOC}]$ is the organic carbon content of the liquid in weight percent carbon, $\mathrm{E}_{\mathrm{Arad}}$ is the activation energy in kilojoules per mole, $\mathrm{R}$ is the gas constant $(8.314 \mathrm{~J} / \mathrm{mole}-\mathrm{K})$, and $\mathrm{T}$ is the absolute temperature in degrees kelvin. The values of $\mathrm{a}_{\mathrm{rad}}$ and the activation energy for the radiolytic reaction were determined by statistical analysis of the rate data compiled in laboratory investigations of the wastes. The value of $\mathrm{a}_{\text {rad }}$ was determined to be $2.49 \times 10^{6}$ molecules of hydrogen per $100 \mathrm{eV}$, and the activation energy was determined to be $44.3 \mathrm{~kJ} / \mathrm{mole}$.

Characterization reports provide the necessary information for calculating $\left(\mathrm{H}_{2}\right)_{\mathrm{H} 2 \mathrm{O}}$ from the concentrations of sodium nitrite and sodium nitrate using Equation 5.13. When these concentrations are not known, the empirically determined default value of 0.005 is used for concentrated solutions. The characterization reports also provide the information necessary to evaluate the total heat load, $\mathrm{H}_{\text {load }}$, in watts per kilogram; the liquid weight fraction of the waste, $\mathrm{L}_{\mathrm{f}}$ and the TOC content in the liquid, [TOC], in weight percent.

The reliability of this relationship was assessed by comparing the relationship between calculated and measured radiolytic hydrogen generation rates for waste samples from tanks 241-AW-101, 241-SY-103, 241-A-101, 241-S-102, and 241-S-106 as shown in Figure 5-2. 


\section{RPP-6664 REV 0}

Figure 5-2. Relationship between Calculated and Observed Radiolytic Hydrogen Generation Rates.

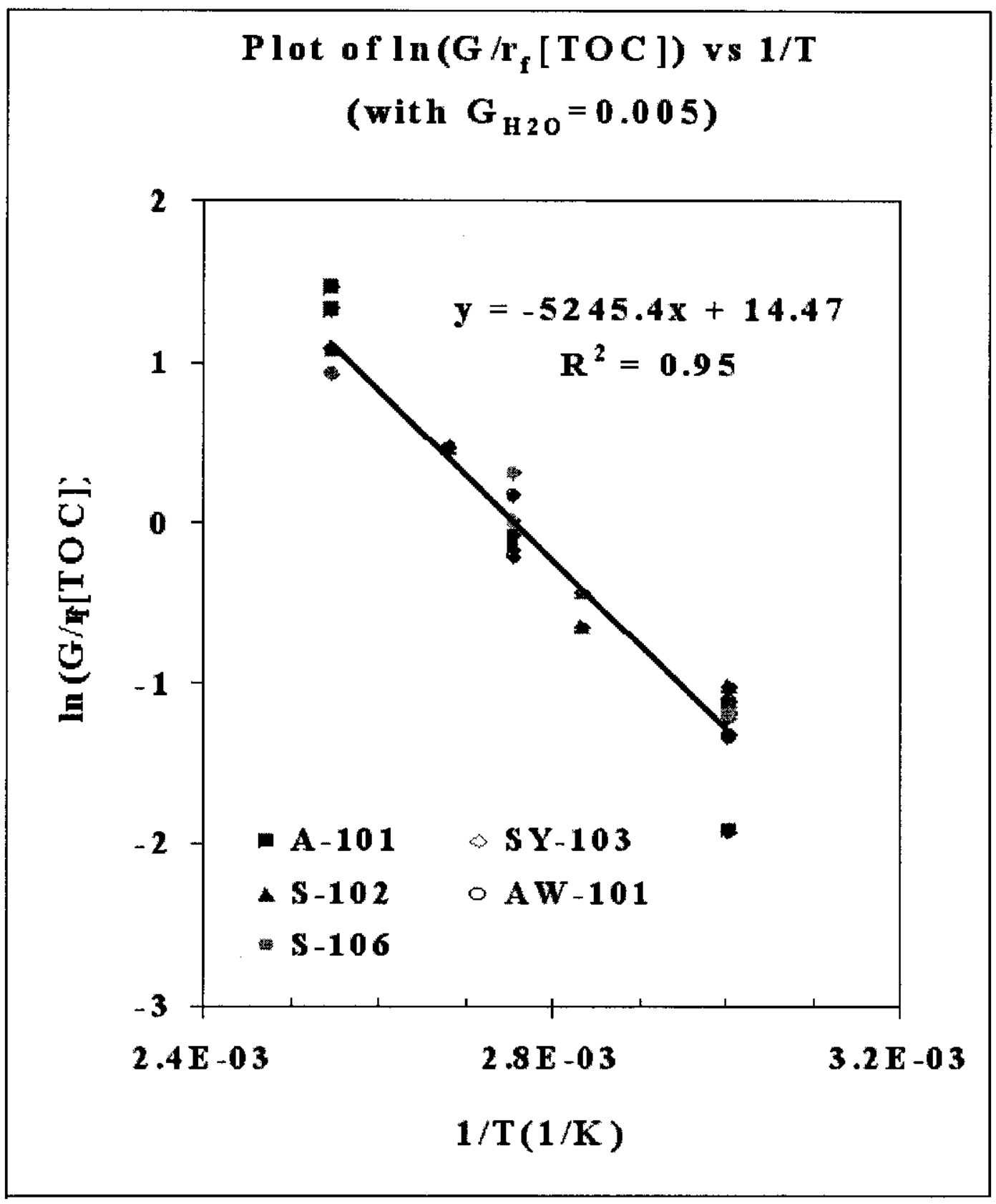




\subsubsection{Corrosion Rates}

The rates of corrosion of the tank liners have been measured in simulated Hanford Site wastes under thermal and irradiated conditions (Strachan 1994). These investigations indicate that the steel corrosion rates are about $0.00025 \mathrm{~mm} / \mathrm{yr}(0.01 \mathrm{mil} / \mathrm{yr})$. The corrosion rates were measured at high $\mathrm{pH}(>13)$ where the mild steel is expected to be passivated (Pourbaix 1974). The $\mathrm{pH}$ in some single-shell tanks may be considerably lower, as low as 9.5, but the available evidence implies that the mild steel liners remain passive (Woodrich et al. 1992). Under neutral or acidic conditions, circumstances not expected at the Hanford Site, the mild steel is expected to corrode much more rapidly, at a rate exceeding $0.025 \mathrm{~mm} / \mathrm{yr}(1 \mathrm{mil} / \mathrm{yr}$ ) (Pourbaix 1974; Elmore 1997).

The corrosion rates have recently been reexamined by Anantatmula (1999). Electrochemical measurements suggest that the corrosion rate in tank 241-AY-102, which has low concentrations of sodium nitrite and sodium nitrate, is less than $0.0025 \mathrm{~mm} / \mathrm{yr}(0.1 \mathrm{mil} / \mathrm{yr})$. Anantatmula (1999) also reexamined the corrosion rates of single-shell tanks, and concluded that the maximum corrosion rate was about $0.004 \mathrm{~mm} / \mathrm{yr}(0.16 \mathrm{mil} / \mathrm{yr})$.

Hu (2000) adopted these estimates and the concept that 1 mole of hydrogen is produced per mole of iron consumed and formulated Equation 5.15 to assess the amount of hydrogen produced by corrosion:

$$
\text { Rate }_{\text {Corr }}=\mathrm{R}_{\text {Cor }} \times \mathrm{A}_{\text {wetted }}
$$

where $\mathrm{R}_{\mathrm{Corr}}$ is $1.8 \times 10^{-8} \mathrm{~m}^{3} / \mathrm{min}-\mathrm{m}^{2}\left(6.0 \times 10^{-8} \mathrm{ft}^{3} / \mathrm{min}-\mathrm{ft}^{2}\right)$ for double-shell tanks and $0.4 \times 10^{-7} \mathrm{~m}^{3} / \mathrm{min}-\mathrm{m}^{2}\left(1.2 \times 10^{-7} \mathrm{ft}^{3} / \mathrm{min}-\mathrm{ft}^{2}\right)$ for single-shell tanks.

\subsection{APPLICATION OF EMPIRICAL MODEL FOR HYDROGEN GENERATION}

The analytical expressions for the thermal generation of hydrogen (Equation 5.9), radiolytic generation of hydrogen (Equation 5.10), and corrosion (Equation 5.15) were employed by $\mathrm{Hu}$ (2000) to calculate the hydrogen generation rates for approximately 30 tanks. The calculated generation rates and the observed rates of hydrogen release are compared in Table 5-1.

Table 5-1. Calculated and Observed Rates of Hydrogen Generation. (2 sheets)

\begin{tabular}{|c|c|c|c|c|c|c|}
\hline Tank & $\begin{array}{l}\text { Calculated } \\
\text { Radiolysis } \\
\text { (mol/kg-day) }\end{array}$ & $\begin{array}{l}\text { Calculated } \\
\text { (mormalkg-day) }\end{array}$ & $\begin{array}{l}\text { Calculated } \\
\text { Corrosion } \\
(\text { mollkg-day) }\end{array}$ & $\begin{array}{l}\text { Calculated } \\
\text { Total } \\
\text { (mol/kg-day) }\end{array}$ & $\begin{array}{l}\text { Calculated }^{2} \\
\text { Total } \\
\text { (L/d) }\end{array}$ & $\begin{array}{c}\text { Observed } \\
\text { rotal } \\
\text { (C/d) }\end{array}$ \\
\hline 241-AN-101 & $3.98 \mathrm{E}-08$ & $4.82 \mathrm{E}-08$ & $8.10 \mathrm{E}-07$ & 8.98E-07 & 15 & 10 \\
\hline 241-AN-103 & $3.37 \mathrm{E}-07$ & $7.39 \mathrm{E}-07$ & $1.84 \mathrm{E}-07$ & $1.26 \mathrm{E}-06$ & 180 & 180 \\
\hline 241-AN-104 & $3.72 \mathrm{E}-07$ & $8.67 \mathrm{E}-07$ & $1.91 \mathrm{E}-07$ & $1.43 \mathrm{E}-06$ & 220 & 210 \\
\hline 241-AN-105 & $3.02 \mathrm{E}-07$ & $7.96 \mathrm{E}-07$ & $1.87 \mathrm{E}-07$ & $1.28 \mathrm{E}-06$ & 210 & 150 \\
\hline 241-AN-107 & $2.46 \mathrm{E}-06$ & $1.15 \mathrm{E}-06$ & $2.09 \mathrm{E}-07$ & $3.82 \mathrm{E}-06$ & 530 & 210 \\
\hline 241-AW-101 & $3.93 E-07$ & $6.65 \mathrm{E}-07$ & $1.92 \mathrm{E}-07$ & $1.25 \mathrm{E}-06$ & 190 & 160 \\
\hline
\end{tabular}


Table 5-1. Calculated and Observed Rates of Hydrogen Generation. (2 sheets)

\begin{tabular}{|c|c|c|c|c|c|c|}
\hline Tank & $\begin{array}{c}\text { Calculated } \\
\text { Radiolysis } \\
(\mathbf{m o l} / \mathbf{k g - d a y})\end{array}$ & $\begin{array}{l}\text { Calculated } \\
\text { Thermal } \\
(\text { molkg day) }\end{array}$ & $\begin{array}{l}\text { Calculated } \\
\text { Corrosion } \\
\text { (molno day) }\end{array}$ & $\begin{array}{l}\text { Calculated } \\
\text { Total } \\
\text { (mollkg day) }\end{array}$ & $\begin{array}{l}\text { Calculated }^{2} \\
\text { Total } \\
\text { (u/d) }\end{array}$ & $\begin{array}{l}\text { Observed } \\
\text { Total } \\
\text { (U/d) }\end{array}$ \\
\hline 241-AY-101 & $1.59 \mathrm{E}-05$ & $4.54 \mathrm{E}-08$ & $7.43 \mathrm{E}-07$ & $1.67 \mathrm{E}-05$ & & \\
\hline 241-AY-102 & $9.07 \mathrm{E}-06$ & $5.55 \mathrm{E}-10$ & $3.33 \mathrm{E}-07$ & $9.40 \mathrm{E}-06$ & 730 & 670 \\
\hline 241-AZ-101 & 4.92E-06 & $2.54 \mathrm{E}-06$ & $2.32 \mathrm{E}-07$ & $7.70 \mathrm{E}-06$ & 930 & 390 \\
\hline 241-AZ-102 & $3.24 \mathrm{E}-06$ & $8.70 \mathrm{E}-07$ & $2.55 \mathrm{E}-07$ & $4.36 \mathrm{E}-06$ & 900 & 780 \\
\hline 241-SY-101 & $1.04 \mathrm{E}-06$ & $3.83 \mathrm{E}-06$ & $1.69 \mathrm{E}-07$ & $5.04 \mathrm{E}-06$ & 780 & 600 \\
\hline 241-SY-102 & $1.82 \mathrm{E}-08$ & 3.54E-09 & $3.07 \mathrm{E}-07$ & $3.28 \mathrm{E}-07$ & 25 & 30 \\
\hline 241-SY-103 & $4.63 \mathrm{E}-07$ & $9.41 \mathrm{E}-07$ & 2.22E-07 & $1.63 \mathrm{E}-06$ & 160 & 150 \\
\hline $241-\mathrm{A}-101$ & $1.92 \mathrm{E}-07$ & $8.60 \mathrm{E}-07$ & $3.62 \mathrm{E}-07$ & $1.41 \mathrm{E}-06$ & 190 & 100 \\
\hline 241-A-102 & $5.08 \mathrm{E}-07$ & $2.00 \mathrm{E}-07$ & $3.52 \mathrm{E}-06$ & $4.22 \mathrm{E}-06$ & & \\
\hline 241-C-104 & 4.19E-07 & 9.49E-08 & $6.71 \mathrm{E}-07$ & $1.18 \mathrm{E}-06$ & 47 & 90 \\
\hline $241-C-105$ & $9.88 \mathrm{E}-07$ & 7.53E-09 & $1.32 \mathrm{E}-06$ & $2.32 \mathrm{E}-06$ & & \\
\hline 241-C-106 & $2.15 \mathrm{E}-05$ & $6.46 \mathrm{E}-07$ & 7.87E-07 & $2.29 \mathrm{E}-05$ & 380 & 370 \\
\hline $241-S-102$ & $1.08 \mathrm{E}-07$ & $3.26 \mathrm{E}-07$ & $4.58 \mathrm{E}-07$ & $8.91 \mathrm{E}-07$ & 71 & 66 \\
\hline $241-S-106$ & 3.63E-08 & $2.04 \mathrm{E}-08$ & 5.12E-07 & $5.68 \mathrm{E}-07$ & & \\
\hline $241-S-111$ & $3.58 \mathrm{E}-08$ & 2.49E-08 & $4.87 \mathrm{E}-07$ & $5.47 \mathrm{E}-07$ & & \\
\hline 241-SX-101 & $7.25 \mathrm{E}-08$ & $5.41 \mathrm{E}-08$ & $4.93 \mathrm{E}-07$ & $6.19 \mathrm{E}-07$ & 43 & 17 \\
\hline 241-SX-103 & $2.49 \mathrm{E}-07$ & $7.75 \mathrm{E}-07$ & $4.02 \mathrm{E}-07$ & $1.43 \mathrm{E}-06$ & 130 & 53 \\
\hline 241-SX-104 & $1.23 \mathrm{E}-07$ & 2.29E-07 & $4.82 \mathrm{E}-07$ & $8.43 \mathrm{E}-07$ & 66 & 10 \\
\hline 241-SX-105 & $3.77 \mathrm{E}-07$ & $1.60 \mathrm{E}-06$ & 4.01E-07 & $2.38 \mathrm{E}-06$ & 230 & 200 \\
\hline 241-SX-106 & $1.53 \mathrm{E}-07$ & $3.54 \mathrm{E}-07$ & $4.91 \mathrm{E}-07$ & $9.98 \mathrm{E}-07$ & 77 & 50 \\
\hline 241-U-102 & $2.40 \mathrm{E}-07$ & $2.86 \mathrm{E}-07$ & $5.97 \mathrm{E}-07$ & $1.12 \mathrm{E}-06$ & 59 & 45 \\
\hline 241-U-103 & $2.36 \mathrm{E}-07$ & $3.55 \mathrm{E}-07$ & $5.12 \mathrm{E}-07$ & $1.10 \mathrm{E}-06$ & 75 & 60 \\
\hline 241-U-105 & $3.80 \mathrm{E}-07$ & $3.95 \mathrm{E}-07$ & 5.54E-07 & $1.33 \mathrm{E}-06$ & 72 & 65 \\
\hline 241-U-106 & $6.08 \mathrm{E}-07$ & $5.82 \mathrm{E}-07$ & $8.82 \mathrm{E}-07$ & $2.07 \mathrm{E}-06$ & 63 & 27 \\
\hline 241-U-107 & $4.07 \mathrm{E}-08$ & $3.17 \mathrm{E}-08$ & $6.33 \mathrm{E}-07$ & 7.05E-07 & 39 & 31 \\
\hline 241-U-108 & $1.06 \mathrm{E}-07$ & $1.71 \mathrm{E}-07$ & $5.08 \mathrm{E}-07$ & $7.86 \mathrm{E}-07$ & 55 & 45 \\
\hline 241-U-109 & $6.03 \mathrm{E}-07$ & $4.36 \mathrm{E}-07$ & $5.48 \mathrm{E}-07$ & $6.51 \mathrm{E}-07$ & 43 & 25 \\
\hline
\end{tabular}

${ }^{a}$ The calculated values were abstracted from Hu, T.A., 2000, Empirical Rate Equation Model and Rate Calculations for Hydrogen Generation for Hanford Tank Waste, HNF-3851, Rev. 0A, Lockheed Martin Hanford Corporation, Richland, Washington.

${ }^{b}$ The observed values were evaluated by $\mathrm{Hu}(2000)$ on the basis of the accumulation and release rates reported by Wilkins, N. E., R. E. Bauer, and D. M. Ogden, 1997, Results of Vapor Space Monitoring of Flammable Gas Watch List Tanks, SD-WM-TI-548, Rev. OA, Lockheed Martin Hanford Corp., Richland, Washington. 


\section{RPP-6664 REV 0}

The calculations indicate that no single mechanism dominates hydrogen generation throughout the tank farms. The thermal hydrogen generation rates range from $5.5 \times 10^{-10}$ to $7.8 \times 10^{-6}$ moles $/ \mathrm{kg}$-day, which is a considerably broader range than that for the other two pathways. The rates for radiolysis range from $1.8 \times 10^{-8}$ to $2.2 \times 10^{-5}$ moles $/ \mathrm{kg}-\mathrm{day}$, and the rates for corrosion range least broadly from $1.7 \times 10^{-7}$ to $3.5 \times 10^{-6}$ moles $/ \mathrm{kg}-$ day. When the temperature is low and there is little radioactive material in the waste, the generation rate is low, and the model implies that corrosion is the principal source of hydrogen. According to the model, the corrosion term contributes more than $50 \%$ of the total hydrogen for 15 of the 33 tanks shown in the table. The variations in the amounts of radioactive material in the wastes lead to variations in the radiolysis generation rate that span three orders of magnitude. Radiolysis becomes the dominant hydrogen source in 6 tanks, contributing more than $50 \%$ of the total hydrogen. The temperature variations also are appreciable, and the thermal generation rates vary by about four orders of magnitude. Thermal generation is the dominant source of hydrogen for the waste in 9 tanks.

The agreement between the calculated and observed hydrogen generation rates can be assessed in several different ways. One way is the compare the ratios of the calculated gas generation rates to the observed gas generation rates. The ratios of the calculated gas generation rates to the observed gas generation rates are 0.53 and 0.83 for 2 tanks, 241-C-104 and 241-SY-102; between 1.0 and 2.0 for 20 tanks, and between 2.0 and 2.5 for 5 other tanks. The only high value

for this ratio, 6.6, was observed for tank 241-SX-104. Among the tanks under consideration tank 241-SX-104 produces the smallest amount of hydrogen, $10 \mathrm{~L} / \mathrm{day}$. The calculation suggests that $66 \mathrm{~L}$ of hydrogen per day should be formed, with $60 \%$ of the hydrogen produced by corrosion.

Another way of assessing the agreement between calculated and observed hydrogen generation rates is to compare the average and median differences between them. The average difference between the calculated and observed generation rates for the entire family of tanks for which field data are available is about $70 \mathrm{~L} /$ day, and the median difference is about $30 \mathrm{~L} /$ day. The median and average differences between the calculated and observed rates for the 15 tanks that generate less than $100 \mathrm{~L} /$ day of hydrogen are about $20 \mathrm{~L}$ day and $25 \mathrm{~L} /$ day, respectively. These observations indicate that the model predicts these low generation rates with adequate accuracy for practical use. The median and average differences between the calculated and observed rates for the tanks that generate more than $100 \mathrm{~L} /$ day of hydrogen are about $60 \mathrm{~L} /$ day and $110 \mathrm{~L} /$ day, respectively. The largest difference between the predicted and observed values occurs for tank 241-AZ-101. In this case, the ratio of the calculated to the observed generation rate is about 2.5 and the model overestimates hydrogen production by about $540 \mathrm{~L} /$ day. Radiolysis and thermal reactions both contribute substantially, but there is no apparent reason for the large discrepancy.

On balance, the model provides realistic estimates of the hydrogen generation rates. It is conservative in the sense that the rates of hydrogen generation are generally overestimated.

\subsection{SUMMARY}

The earliest models used to calculate hydrogen generation rates calculated the rates within a factor of three by evaluating radiolytic and thermal contributions based upon variables such as dose rate, organic carbon content, and temperature. One tank or one waste simulant, for which 
the hydrogen generation rate had been established, was used as a reference point in these calculations.

Observations made in recent laboratory studies and field work have provided a better technical understanding of the factors governing the rates of hydrogen generation. These contributions were utilized by $\mathrm{Hu}(2000)$ to create a more general model for hydrogen generation. This model relates the hydrogen generation rate to the sum of the contributions of corrosion, radiolysis, and thermal processes in the liquid phases of the waste. The thermal generation rate depends on the organic and aluminum content of the waste and the waste temperature. The radiolytic term is partitioned between the radiolysis of water and the radiolysis of the organic matter. The first term is temperature independent and depends on the radiation dose and the quantities of sodium nitrate and sodium nitrite in the waste. The second term is temperature dependent and depends on the amount of reactive organic molecules in the waste as well as the radiation dose.

The model has been used to calculate the rates of hydrogen generation for more than 30 tanks. The model indicates that radiolysis and thermal generation rates extend over four orders of magnitude, and that radiolysis, thermal reactions, or corrosion can be responsible for the generation of more than $50 \%$ of the hydrogen in a waste. When the radiation dose and temperature are low, the model predicts that the hydrogen generation rate will be low, less than $100 \mathrm{~L} /$ day, and corrosion is usually the dominant source of hydrogen. When the radiation dose or temperature is high, the model predicts that the hydrogen generation rate will increase to as much as $900 \mathrm{~L} /$ day. The model generally overestimates the hydrogen generation rate by about $50 \%$ in these circumstances. On balance, the model has good predictive capability for the estimating the rates of hydrogen generation. 


\section{RPP-6664 REV 0}

This page intentionally left blank. 


\section{RPP-6664 REV 0}

\subsection{REFERENCES}

Abel, E., 1956, "Mechanism and Kinetics of the Formation of Hydrogen from Alkaline Solutions of Formaldeehyde and Hydrogen Peroxide," Z. Physik Chem., Frankfurt, Vol.7, P 101-7.

Agnew, S. F., 1995, Hanford Defined Wastes: Chemical and Radionuclide Compositions, LA-UR-2657, Rev. 2, Los Alamos National Laboratory, Los Alamos, New Mexico.

Agnew, S. F., 1996, Hanford Defined Wastes: Chemical and Radionuclide Inventories: HDW Model, LA-UR-96-858, Rev. 3, Los Alamos National Laboratory, Los Alamos, New Mexico.

Agnew, S. F., R. A. Corbin, T. B. Duran, K. A. Jurgenson, T. P. Ortiz, and B. L. Young, 1995, Waste Status and Transaction Record Summary (WSTRS), WHC-SD-WM-TI-615, Rev. 1, Westinghouse Hanford Company, Richland, Washington.

Agnew, S. F., R. A. Corbin, T. B. Duran, K. A. Jurgenson, J. Fitzpatrick, B. L. Young, J. Boyer, and T. P. Ortiz, 1997, Hanford Tank Chemical and Radionuclide Inventories: Hanford Defined Wastes (HDW) Model, Rev. 4, WHC-SD-WM-TI-615, Westinghouse Hanford Company, Richland, Washington.

Allen, G. K., 1976, Estimated Inventory of Chemicals Added to Underground Waste Tanks, 1944 Through 1975, ARH-CD-610B, Atlantic Richfield Hanford Company, Richland, Washington.

Anantatmula, R. P., 1999, Recommendation of Uniform Corrosion Rates for Double-Shell and Single-Shell Tanks (Internal Memo 74700-99RPA-006 to K. M. Hodgson, January 29), Lockheed Martin Hanford Corporation, Richland, Washington.

Ashby, E. C., R. Doctorovich, C. L. Liotta, M. Neumann, E. K. Barefield, A. Konda, K. Zhang, and J. H. Hurley, 1993, "Concerning the Formation of Hydrogen in Nuclear Waste. Quantitative Generation of Hydrogen via a Canizzaro Intermediate," J. Am. Chem. Soc., Vol. 115, p. 1171.

Ashby, E. C., A. Annis, E. K. Barefield, D. Boatright, R. Doctorovich, C. L. Liotta, H. M. Neumann, C. F. Yao, K. Zhang, and N. F. McDuffie, 1994, Synthetic Waste Chemical Mechanism Studies, WHC-EP-0823, Westinghouse Hanford Company, Richland, Washington.

Assefa, Z., and D. M. Stanbury, 1997, "Oxidation of Coordinated Ammonia to Nitrosyl in the Reaction of Aqueous Chlorine with cis-[Ru(bpy $\left.)_{2}\left(\mathrm{NH}_{3}\right)_{2}\right]^{2+}$," J. Am. Chem. Soc., Vol. 119, pp. 521-530.

Barefield, E. K., D. Boatright, A. Desphande, R. Doctorovich, C. L. Liotta, H. M. Neumann, and S. Seymore, 1995, Mechanisms of Gas Generation from Simulated SY Tank Farm Wastes: FY 1994 Progress Report, PNL-10822, Pacific Northwest Laboratory, Richland, Washington. 


\section{RPP-6664 REV 0}

Barefield, E. K., D. Boatright, A. Desphande, R. Doctorovich, C. L. Liotta, H. M. Neumann, and S. Seymore, 1996, Mechanisms of Gas Generation from Simulated SY Tank Farm Wastes: FY 1995 Progress Report, PNL-11247, Pacific Northwest Laboratory, Richland, Washington.

Barney, G. S., 1995, The Solubilities of Significant Organic Chemicals in HLW Tank Supernatant Solutions-FY 1995 Progress Report, WHC-EP-0899, Westinghouse Hanford Company, Richland, Washington.

Barney, G. S., 1996, The Solubilities of Significant Organic Chemicals in HLW Tank Supernatant Solutions-FY 1996 Progress Report, WHC-EP-0899-1, Westinghouse Hanford Company, Richland, Washington.

Barney, G. S., 1997, The Solubilities of Significant Organic Chemicals in HLW Tank Supernatant Solutions-FY 1997 Progress Report, WHC-EP-0899-2, Westinghouse Hanford Company, Richland, Washington.

Bonfoey, D. B., M. J. Duchsherer, G. A. Fies, L. D. Lockard, K.O. Pennock, L. A. Pingel, J. Y. Smith, M. Stauffer, R. S. Viswanath, M. L. Myers, and L. L. Lockrem, 1999, Tank Vapor Sampling and Data Analysis Package for Tank 241-C-106 Waste Retrieval Sluicing System Process Test, Sampled December 16, 1998, HNF-3949, Rev. 0, Numatec Hanford Corp., Richland, Washington.

Bonifacic', M., I. Stefanic', G. L. Hug, D. A. Armstrong, and K. D. Asmus, 1998, "Glycine Decarboxylation: The Free Radical Mechanism," J. Am. Chem. Soc., Vol. 120, pp. $9930-9940$.

Bonner, F. T., and B. Ravid, 1975, "Thermal Decomposition of Oxyhyponitrite (Sodium Trioxodinitrate (II)) in Aqueous Solution," Inorg. Chem., Vol. 14, p. 558-563.

Bonner, F. T., L. S. Dzelzkalns, and J. A. Bonucci, 1978, "Properties of Nitroxyl as Intermediate in the Nitric Oxide - Hydroxylamine Reaction and in Trioxodinitrate Decomposition," Inorg. Chem., Vol. 17, p. 2487.

Bottomly, F., and R. C. Burns, 1979, Treatise on Nitrogen Fixation, Wiley Interscience, New York..

Brendt, D. C., and R. L. Fuller, 1966, "The Chemistry of Benzylhydroamate" J. Org. Chem., Vol. 31, p. 3312.

Bryan, S. A., and C. M. King, 1998, Thermal and Radiolytic Gas Generation from Tank 241-AW-101: Status Report, Pacific Northwest Laboratory TWS98.39, Richland, Washington.

Bryan, S. A., and L. R. Pederson, 1994, Composition, Preparation, and Gas Generation Results from Simulated Wastes of Tank 241-SY-101, PNL-10075, Pacific Northwest Laboratory, Richland, Washington. 


\section{RPP-6664 REV 0}

Bryan, S. A., and L. R. Pederson, 1995, Thermal and Combined Thermal and Radiolytic Reactions Involving Nitrous Oxide, Hydrogen, and Nitrogen in the Gas Phase; Comparison of Gas Generation Rates in Supernate and Solid Fractions of Tank 241-SY-101 Simulated Waste, PNL-10490, Pacific Northwest Laboratory, Richland, Washington.

Bryan, S. A., L. R. Pederson, C. M. King, S. V. Forbes, and R. L. Sell, 1996, Gas Generation from Tank 241-SY-103, PNNL-10978, Pacific Northwest National Laboratory, Richland, Washington.

Bryan, S. A., C. M. King, and L. R. Pederson, 1997, Gas Generation from Tank 241-S-102, PNNL-1 1600, Pacific Northwest National Laboratory, Richland, Washington.

Buchholz, J. R., and R. E. Powell, 1963, "The Decomposition of Hyponitrous Acid. I. The NonChain Reaction," J. Am. Chem. Soc., Vol. 85, p. 509.

Bugaenko, L. T., M. G. Kuzmin, and L. S. Polak, 1993, High Energy Chemistry, Ellis Horwood PTR, Prentice Hall, New York.

Burger, L. L., 1955, The Chemistry of Tributyl Phosphate: A Review, HW-40910, Hanford Atomic Products Operation, Richland Washington.

Burger, L. L., 1995, Calculation of Reaction Energies and Adiabatic Temperatures for Waste Tank Reactions, PNL-8557 Rev. 1, Pacific Northwest Laboratory, Richland, Washington.

Buxton, G. V., C. L. Greenstock, W. P. Helman, and A. B. Ross, 1988, "Critical Review of Rate Constants for Reactions of Hydrated Electrons, Hydrogen Atoms, and Hydroxyl Radicals in Aqueous Solution," J. Phys. Chem. Ref. Data, Vol. 17(2), p. 513-886.

Camaioni, D. M., and T. Autrey, 2000, "Thermochemical Kinetic Analysis of Mechanism for Thermal Oxidation of Organic Complexants in High Level Waste," in First Accomplishments of the Environmental Management Science Program, P. G. Eller and W. R. Heineman, Editors, ACS Symposium Series, American Chemical Society, Washington, D.C.

Camaioni D. M., and J. Linehan, 1999, Letter Report to KG Carothers on Tests for the Decomposition of Bis(2-Ethylhexyl)phosphate in Molar Sodium Hydroxide, Pacific Northwest National Laboratory, Richland, Washington.

Camaioni, D. M., W. D. Samuels, S. A. Clauss, J. C. Lenihan, K. L. Wahl, J. A. Campbell, and W. J. Shaw, 1995, Organic Tanks Safety Program FY95 Waste Aging Studies, PNL-10794, Pacific Northwest Laboratory, Richland, Washington.

Camaioni, D. M., W. D. Samuels, S. A. Clauss, A. K. Sharma, and K. L. Wahl, 1996a, Alkaline Hydrolysis of Simulated Tank 241-C-103 Separable Organic Phase, Letter Report OT: 040896, Pacific Northwest Laboratory, Richland, Washington. 


\section{RPP-6664 REV 0}

Camaioni, D. M., W. D. Samuels, J. C. Linehan, S. A. Clauss, A. K. Sharma, K. L. Wahl, and J. A. Campbell, 1996b, FY 1996 Waste Aging Studies, PNNL-11312, Pacific Northwest National Laboratory, Richland, Washington.

Camaioni, D. M., W. D. Samuels, J. C. Lenihan, A. K. Sharma, M. O. Hogan, M. A. Lilga, S. A Clauss, K. L Wahl, and J. A. Campbell, 1997, Organic Tanks Safety Program FY 97 Waste Aging Studies, PNNL-10794, Pacific Northwest National Laboratory, Richland, Washington.

Camaioni, D. M., W. D. Samuels, J. C. Lenihan, A. K. Sharma, S. T. Autrey, M. A. Lilga, M. O. Hogan, S. A. Clauss, K. L. Wahl, and J. A. Campbell, 1998, Organic Tanks Safety Program Waste Aging Studies Final Report, PNNL-1 1909, Pacific Northwest National Laboratory, Richland, Washington.

Campbell, J. A., S. A. Clauss, K. E. Grant, V. Hoopes, B. D. Lerner, R. B. Lucke, G. M. Mong, J. K. Rau, R. Steele, and K. L. Wahl, 1994, Waste Tank Organic Safety Program Analytical Methods Development: FY 1994 Progress Report, PNNL-10128, Pacific Northwest National Laboratory, Richland, Washington.

Campbell, J. A., R. M. Bean, K. L. Wahl, G. M. Mong, K. E. Bell, K. B. Werner, A. D. Rice, R. J. Ray, D. B. Bechtold, B. R. Wels, R. W. Schroeder, J. W. Ball, B. D. Valenzuela, J. M. Frye, S. L. Fitzgerald, P. P. Bachelor, B. Griffin, R. K. Fuller, A. B. Benally, and S. M. Parong, 1995a, Waste Tank Analytical Safety Project. Analysis of Samples from Hanford Waste Tanks 241-C-102, 241-BY-108, and 241-C-103, PNNL-10531, Pacific Northwest National Laboratory, Richland, Washington.

Campbell, J. A., S. A. Clauss, V. Hoopes, J. Rau, K. L. Wahl, B. D. Lerner, K. E. Grant, G. M. Mong, and R. Scheele, 1995b, Flammable Gas Program Organic Analysis and Analytical Methods Development: FY 1995 Progress Report, PNNL-10776, Pacific Northwest National Laboratory, Richland, Washington.

Campbell, J. A., K. L Wahl, S. A. Clauss, K. E. Grant, V. Hoopes, G. M. Mong, J. Rau, and R. Steele, 1996a, Organic Tanks Safety Program: Advanced Organic Analysis FY 1996 Progress Report, PNNL-11309, Pacific Northwest National Laboratory, Richland, Washington.

Campbell, J. A., S. A. Clauss, K. E. Grant, V. Hoopes, G. M. Mong, J. Rau, R. Steele, and K. H. Wahl, 1996b, Flammable Gas Safety Program: Actual Waste Organic Analysis FY 1996 Progress Report, PNNL-11307, Pacific Northwest National Laboratory, Richland, Washington.

Campbell, J. A., S. A. Clauss, K. E. Grant, V. Hoopes, G. M. Mong, R. Steele, D. Bellofatto, and A. Sharma, 1997, Organic Analysis Progress Report FY 1997, PNNL-11738, Pacific Northwest National Laboratory, Richland, Washington.

Campbell, J. A., S. A. Clauss, K. E. Grant, V. Hoopes, G. M. Mong, R. Steele, D. Bellofatto, and A. Sharma, 1998, Organic Analysis Progress Report FY 1998, PNNL-11955, Pacific Northwest National Laboratory, Richland, Washington. 


\section{RPP-6664 REV 0}

Carey, F. A., and R. J. Sundberg, 1990, Advanced Organic Chemistry, Third Edition, Plenum Press, Inc., New York, New York.

Challis, B. C., and D. E. G. Shuker, 1979, "Rapid Nitrosation of Amines in Aqueous Alkaline Solutions by $\beta$-Substituted Alkyl Nitrites," J. Chem. Soc. Chem. Commun., pp. 315-316.

Coffey, S., 1965, "Dihydritic Alcohols Their Oxidation Products and Derivatives," Elsevier Publishing Company, New York, New York.

Cotton, F. A., and G. Wilkinson, 1988, Advanced Inorganic Chemistry, Fifth Edition, John Wiley and Sons, New York.

Cowley, W. L., J. E. Meacham, J. M. Grigsby, and A. K. Postma, 1998, Organic Solvent Topical Report, HNF-SD-WM-CN-032, Rev. 1, Duke Engineering and Services Hanford, Inc., Richland Washington.

Cowley, W. L., D. A. Reynolds, K. R. Sandgren, S. R. Wilmarth, J. C. Van Keuven, G. Bruce, R. L. Pleus, J. L. Huckaby, and L. A. Mahoney, 2000, Toxicological Source Terms for Tank Farms Safety Analyses, RPP-6965, Rev. 0, CH2M HILL Hanford Group, Inc., Richland, Washington.

Cox, J. R., Jr., and O. B. Ramsey, 1964, "Mechanisms of Nucleophilic Substitution in Phosphate Esters," Chemicals Reviews, Vol. 64, p. 317.

Czapski, G., J. Holeman, and B. H. J. Bielski, 1994, "Reactivity of Nitric Oxide with Short-Lived Radicals in Aqueous Solutions," J. Am. Chem. Soc., Vol. 116, pp. 11465-11469.

Davis, W. Jr., 1984, "Radiolytic Behavior," in Science and Technology of Tributyl Phosphate, W. W. Schultz, and J. D. Navratil, Editors, Volume I, CRC Press, Boca Raton, Florida.

Delegard, C. H., 1980, Laboratory Studies of Complexed Waste Slurry Volume Growth in Tank 241-SY-101, RHO-LD-124, Rockwell Hanford Operations, Richland, Washington.

Delegard, C. H., 1987, Identities of HEDTA and Glycolate Degradation Products in Simulated Hanford High-Level Waste, RHO-RE-ST-55P, Rockwell Hanford Operations, Richland, Washington.

Elmore, M. R., 1997, Corrosion of Mild Steel in Simulated Cesium Elution Process Solutions, PNNL-1 1284, Pacific Northwest National Laboratory, Richland, Washington.

Evans, J. C., A. V. Mitroshkov, and L. A. Mahoney, 1999, SY-101 Retained Gas Vapor GC/MS Analysis, TW399.31, Pacific Northwest National Laboratory, Richland, Washington.

Fessenden, R. W., D. Meisel, and D. C. Camaioni, 2000, "Addition of Oxide Radical Ions (O') to Nitrite and Oxide Ion $\left(\mathrm{O}^{2-}\right)$ to Nitrogen Dioxide," J. Am. Chem. Soc., Vol. 122, pp. 3773-3775. 


\section{RPP-6664 REV 0}

Fukuto, J. M., and L. J. Ignarro, 1997, "In Vivo Aspects of Nitric Oxide Chemistry: Does Peroxynitrite Play a Major Role in Cytotoxicity?," Acct. Chem. Res., Vol. 30, p. 149.

Graves, R. D., 1994, Topical Report on Flammable Gases in Non-Burping Waste Tanks, WHC-SD-WM-SARR-015, Rev. 0, Westinghouse Hanford Company, Richland, Washington.

Grove Engineering, 1987, RADDECAY Program: Data from D. C. Kocher, "Radioactive Decay Tables," DOE/TIC-11026.

Gyorgy, I., 1981, "Aliphatic Hydrocarbons" in Radiation Chemistry of Hydrocarbons, G. Foldiak, Editor, Elsevier Scientific Publishing Company, Amsterdam, Netherlands.

Han, P., and D. M. Bartels, 1990, "Reevaluation of Arrhenius Parameters for $\mathrm{H}+\mathrm{OH}^{-} \rightarrow\left(\mathrm{e}^{-}\right)+\mathrm{H}_{2} \mathrm{O}$ and the Enthalpy and Entropy of Hydrated Electrons," J. Phys. Chem., Vol. 94, pp. 7294-7299.

Harteck, P., and S. Dondes, 1956, "Nitrous Oxide Dosimeter for High Levels of Beta, Gammas, and Thermal Neutrons," Nucleonics I, Vol. 14, pp. 66-72.

Hawthorne, M. F., 1957, "aci-Nitro alkanes.II. The Mechanism of the Nef Reaction," J. Am. Chem. Soc., Vol. 79, p. 2510.

Hedengren, D. C., S. A. Barker, R. J. Hendershot, J. D. Bingham, M. A. Kaufahl, 2000, Methodology for Predicting Flammable Gas Mixtures in Double-Contained Receiver Tanks, RPP-4941, Rev. OA, CH2M HILL Hanford Group, Inc., Richland, Washington.

Hermann, C., I. Dewes, and A. Schumpe, 1995, Chemical Engineering Science, Vol. 50, p. 1673.

Hertzberg, M., and I. A. Zlochower, 1994, "Reaction of Nitrous Oxide," in Proceedings of the 25th International Symposium on Combustion, p.254, The Combustion Institute, Pittsburgh, Pennsylvania.

Hobel, B. and C. von Sontag, 1998, "The Hydroxyl Radical-Induced Decomposition of Ethylenediaminetetraacetate," J. Chem. Soc., Perkin Trans. 2, p. 509.

Hopkins, J. D., 1994, Criteria for Flammable Gas Watch List Tanks, WHC-EP-0702, Rev. 0, Westinghouse Hanford Company, Richland, Washington.

Hopkins, J. D., 1995, Methodology for Flammable Gas Evaluations, WHC-SD-WM-TI-724, Rev. 0, Westinghouse Hanford Company, Richland, Washington

Hu, T. A., 1997, Calculations of Hydrogen Release Rate at Steady State for Double-Shell Tanks, HNF-SD-WM-CN-117, Rev. 0, Lockheed Martin Hanford Corporation, Richland, Washington.

Hu, T. A., L. W. Shelton, and T. L. Welsh, 1997, Tank Characterization Report for Double-Shell Tank 241-AN-104, HNF-SD-WM-ER-690, Rev. 0, Lockheed Martin Hanford Corporation, Richland, Washington. 


\section{RPP-6664 REV 0}

Hu, T. A., 2000, Empirical Rate Equation Model and Rate Calculations for Hydrogen Generation for Hanford Tank Waste, HNF-3851, Rev. 0A, Lockheed Martin Hanford Corporation, Richland, Washington.

Huckaby, J. L., J. A. Edwards, J. C. Evans, J. S. Fruchter, J. L. Julya, K. B. Olsen, K. H. Pool, B. L. Thomas, K. L. Silvers, L. Jensen, L. L. Buckley, S. R. Wilmarth, and L. D. Pennington, 1996, Comparison of Vapor Sampling System (VSS) and In Situ Vapor Sampling (ISVS) Methods on Tanks C-107, BY-108, and S-102, PNNL-11186, Pacific Northwest National Laboratory, Richland, Washington.

Huckaby, J. L., J. A. Glissmeyer, and D. S. Sklarew, 1997, Screening for Organic Solvents in Hanford Waste Tanks Using Total Non-Methane Organic Compound Vapor Concentrations, PNNL-11490, Pacific Northwest National Laboratory, Richland Washington.

Hughes, M. N., and G. Stedman, 1963, "Kinetics and Mechanism of the Decomposition of Hyponitrous Acid," J. Chem. Soc., p. 1239.

Hughes, M. N., and R. E. Wimbledon, 1976, "The Chemistry of Trioxodinatrates. Part I. Decompositon of Sodium Trioxodinitrate (Angeli's Salt) in Aqueous Solution, J. Chem Soc., Dalton Trans., p. 703.

Janaway, G. A. , M. Zhong, G. O. Gatev, M. L. Chabinyc, and J. I. Brauman, 1997, “[FHNO]: An Intermediate in a Spin Forbidden Proton Transfer Reaction," J. Am. Chem. Soc., Vol. 119, p. 11697.

Jansky, M. T., 1980a, 101A Hot Boildown, (Memorandum 65453-80-241 to M. C. Teats, August 22), Rockwell Hanford Operations, Richland, Washington.

Jansky, M. T., 1980b, Solids in 101A Waste, (Memorandum 65453-80-267 to M. C. Teats, September 22), Rockwell Hanford Operations, Richland, Washington.

Jansky, M. T., 1980c, Composition of 101A Waste, (Memorandum 65453-80-302 to M. C. Teats, October 13), Rockwell Hanford Operations, Richland, Washington.

Jansky, M. T., 1980d, 101A Waste Sample, (Memorandum 65453-80-336 to M. C. Teats, November 13), Rockwell Hanford Operations, Richland, Washington.

Jansky, M. T., 1980e, 101A Waste Sample Characteristics, (Memorandum 65453-80-337 to M. C. Teats, November 17), Rockwell Hanford Operations, Richland, Washington.

Jansky, M. T., 1981, HEDTA/EDTA Content in the Second Double-Shell Slurry Campaign Product, (Memorandum 65453-81-041 to L. A. Gale, February 11), Rockwell Hanford Operations, Richland, Washington.

Jansky, M. T., 1984, Waste Samples from Tank 101-A (Chemical Samples 7879 and 7898), (Memorandum 65453-84-003 to T. D. Kirkpatrick, January 3), Rockwell Hanford Operations, Richland, Washington. 
Jencks, W. P., 1969, Catalysis in Chemistry and Enzymology, McGraw-Hill Book Co., New York, New York.

Jenkins, R. A., A. B. Dindal, C. E. Huggins, C. Y. Ma, J. T. Skeen, and R. R. Smith, 1994, Analysis of Tank 241-C-103 Headspace Components from Sampling Job 7b, Oak Ridge National Laboratory, Oak Ridge, Tennessee.

Johnson, G. D., W. B. Barton, R. C. Hill, J. W. Brothers, S. A. Bryan, P. A. Gauglitz, L. R. Pederson, C. W. Stewart, and L. M. Stock, 1997, Flammable Gas Program Topical Report, HNF-SP-1193, Rev. 2, Fluor Daniel Hanford, Inc., Richland, Washington.

Karpoor, S., F. A. Barnabas, M. C. Sauer, Jr., D. Meisel, and C. D. Jonah, 1995, "Kinetics of Hydrogen Formation from Formaldehyde in Aqueous Solution," J. Phys. Chem., Vol. 99, pp. 6857-6863.

King, C. M., and S. A. Bryan, 1998, Thermal and Radiolytic Gas Generation from Tank 241-A-101: Status Report, PNNL-TWS98.78, Pacific Northwest National Laboratory, Richland, Washington.

King, C. M., and S. A. Bryan, 1999, Thermal and Radiolytic Gas Generation Tests on Material from Tank 241-U-103, 241-AW-101, 241-S-106, and 241-S-102: Status Report, PNNL-12181, Pacific Northwest National Laboratory, Richland, Washington.

King, C. M., S. A. Bryan, and L. R. Pederson, 1997, Gas Generation from Tank 241-S-102, PNNL-11600, Pacific Northwest National Laboratory, Richland, Washington.

Leffler, J. E., 1993, An Introduction to Free Radicals, John Wiley and Sons, Inc. New York, New York.

Leti, J. and D. Meyerstein, 1972, "The Reaction of Oxygen Anion Radical with the Aminoacetate Ion," Inorg. Chem., Vol. 11, pp. 2397-3401.

Lilga, M. A., R. T. Hallen, E. V. Anderson, M. O. Hogan, T. L. Hubler, G. L. Jones, D. J. Kowalski, M. R. Lumetta, W. F. Reimath, R. A. Romine, G. F. Schiefelbein, and M. R. Telander, 1996, Ferrocyanide Safety Project Ferrocyanide Aging Studies Final Report, PNNL-11211, Pacific Northwest National Laboratory, Richland, Washington.

Lowry, T. H., and K. S. Richardson, 1987, Mechanism and Theory in Organic Chemistry, Third Edition, Harper and Row Publishers, New York, New York.

Lunak, S. and J. Veprek-Siska, 1974, "The Catalytic Effects of Cations on the Decomposition of Alkaline Solutions of Hydroxylamine," Coll. Czech. Chem. Commun., Vol. 39, p. 391.

MacNeil, J. H., P. A. Berseth, E. L.Bruner, T. L. Perkins, Y. Wadia, G. Westwood, and W. C. Trogler, 1997, "Mechanism of Nitrous Oxide Formation by Metal-Catalyzed Reduction of Nitric Oxide in Aqueous Solution," J. Am. Chem. Soc., Vol. 119, p. 1668.

Mahoney, L. A., 2000, Ammonia Results Review for Retained Gas Sampling, PNNL-13317, Rev. 0, Pacific Northwest National Laboratory, Richland, Washington. 
Mahoney, L. A., Z. I. Antoniak, J. M. Bates, and M. E. Dahl, 1999, Retained Gas Sampling Results for the Flammable Gas Program, PNNL-13000, Pacific Northwest National Laboratory, Richland, Washington.

Mahoney, L. A., J. L. Huckaby, S. A. Bryan, G. D. Johnson, 2000, Overview of the Flammability of Gases Generated in Hanford Waste Tanks, PNNL-13269, Rev. 0, Pacific Northwest National Laboratory, Richland, Washington.

March, J., 1992, Advanced Organic Chemistry: Reactions, Mechanisms, and Structure, Fourth Edition, John Wiley and Sons, New York.

McCain, D. J., 1999, Results of Vapor Space Monitoring of Flammable Gas Watch List Tanks, HNF-SD-WM-TI-797, Rev. 4, Lockheed Martin Hanford Corporation, Richland, Washington.

Meacham, J. E., W. L. Cowley, A. B. Webb, N. W. Kirch, J. A. Lechelt, D. A. Reynolds, L. A. Stauffer, D. M. Camaioni, F. Gao, R. T. Hallen, P. G. Hessler, J. L. Huckaby, R. D. Scheele, C. S. Simmons, J. J. Toth, D. B. Bechtold, and L. M. Stock, 1998, Organic Complexant Topical Report, HNF-SD-WM-CN-058, Rev. 0, Duke Engineering Services Hanford, Inc., Richland, Washington.

Meisel, D., and C. M. Camaioni, 1998, "The Nox System in Nuclear Waste," EMSP Project Summaries, pp 125-127, Environmental Management Science Program Workshop, CONF-980736, U.S. Department of Energy, Washington, D.C.

Meisel, D., H. Diamond, E. P. Horwitz, C. D. Jonah, M. S. Matheson, M. C. Sauer, Jr., and J. C. Sullivan, 1991a, Radiation Chemistry of Synthetic Waste, ANL-91/40, Argonne National Laboratory, Argonne, Illinois.

Meisel, D., H. Diamond, E. P. Horwitz, C. D. Jonah, M. S. Matheson, M. C. Sauer, Jr., J. C. Sullivan, F Barnabas, E Cerny, and Y. D. Cheng, 1991b, Radiolytic Generation of Gases from Synthetic Waste, ANL-91/41, Argonne National Laboratory, Argonne, Illinois.

Meisel, D., C. D. Jonah, S. Kapoor, M. S. Matheson, and M. C. Sauer, Jr., 1993, Radiolytic and Radiolytically Induced Generation of Gases from Synthetic Wastes, ANL-93/43, Argonne National Laboratory, Argonne, Illinois.

Meisel, D., A. Cook, D. M. Camaioni, and T. Orlando, 1997, "Chemistry, Radiation, and Interfaces in Suspensions of Nuclear Waste Simulants," in Proceedings of the Joint International Meeting of the Electrochemical Societies, Paris, France, August 31 through September 5, 1997.

Meisel, D., D. M. Camaioni, and T. M. Orlando, 2000, "Radiation and Chemistry in Nuclear Waste: The Nox System and Organic Aging," in First Accomplishments of the Environmental Management Science Program, P. G. Eller and W. R. Heineman, Editors, ACS Symposium Series, American Chemical Society, Washington, D.C. 
Mezyk, S. P., and D. M. Bartels, 1997, "Temperature Dependence of Hydrogen Atom Reaction with Nitrate and Nitrite Species in Aqueous Solution," J. Phys. Chem., A, Vol. 101, pp. 6233-6237.

Nast, R., and I. Foppl, 1948, "The Formation of Hyponitrite by the Disproportionatioon of Hydroxylamine," Z. anorg. allgem. Chem., Vol. 256, p. 159.

Neta, P., R. E. Huie, and A. B. Ross, 1988, "Rate Constants for Reactions of Inorganic Radicals in Aqueous Solution," J. Phys. Chem. Ref. Data, Vol. 17, pp. 1027-1284.

Neta, P., and R. H. Schuler, 1975, "Rate Constants for the Reaction of O" Radicals with Organic Substrates in Aqueous Solutions," J. Phys. Chem., Vol. 79, pp. 1-6.

Noland, W. E., 1955, “The Nef Reaction,” Chem. Rev., Vol. 55, p. 137.

Norton, J. D., and L. R. Pederson, 1994, Ammonia in Simulated Hanford Double-Shell Tank Wastes: Solubility and Effects on Surface Tension, PNL-10173, Pacific Northwest Laboratory, Richland, Washington.

Norton, J. D., and L. R. Pederson, 1995, Solubilities of Gases in Simulated Tank 241-SY-101 Wastes, PNL-10785, Pacific Northwest Laboratory, Richland, Washington.

Oae, S., N. Asai, and K. Fujimori, 1978, "Alkaline Hydrolysis of Alkyl Nitrites and Related Carboxylic Esters,” J. Chem. Soc., Perkin Trans. II, pp. 571-577.

Pederson, L. R., and S. A. Bryan, 1996, Status and Integration of Studies of Gas Generation in Hanford Waste, PNNL-1 1297, Pacific Northwest National Laboratory, Richland, Washington.

Person, J. C., 1996, Effects of Oxygen Cover Gas and NaOH Dilution on Gas Generation in 241-SY-101 Waste, WHC-SD-WM-DTR-043, Rev. 0, Westinghouse Hanford Company, Richland, Washington.

Person, J. C., 1998, Gas Generation in Tank 241-AN-105 Waste With and Without Oxygen Reactions, HNF-2038, Rev. 0, Numatec Hanford Corp. for Fluor Daniel Hanford, In., Richland, Washington.

Pinnick, H. W., 1990, “The Nef Reaction," Organic Reactions, Vol. 38, p. 655.

Pool, K. H., and R. M. Bean, 1994, Waste Tank Organic Safety Project Analysis of Liquid Samples from Hanford Waste Tank 241-C-103, PNNL-9403, Pacific Northwest National Laboratory, Richland, Washington.

Pourbaix, M., 1974, Atlas of Electrochemical Equilibrium in Aqueous Solutions, Second English Edition, National Association of Corrosion Engineers, Houston, Texas.

Preston, K. F., and Cvetanovic, 1972, Comprehensive Chemical Kinetics, Vol.4: Decomposition of Inorganic and Organometallic Compounds, John Wiley and Sons, New York, New York. 
Reszka, K. J., P. Bilski, C. F. Chignell, 1996, "EPR and Spin Trapping Investigations of Nitric Oxide from UV Irradiated Nitrite Anions in Alkaline Aqueous Solutions," J. Am. Chem. Soc., Vol. 118, p. 8719.

Reynolds, D. A., 1992, Current Understanding of Composition of Gas from SY-101 (Memorandum 7K210-92-310 to C. E. Hansen, May 4), Westinghouse Hanford Company, Richland, Washington.Sederburg, J. P., and J. A. Reddick, 1994, TBP and Diluent Mass Balances in the PUREX Plant at Hanford 1955-1991, WHC-SD-WM-ER-396, Rev 0, Westinghouse Hanford Company, Richland, Washington.

Shekarriz, A., D. R. Rector, L. A. Mahoney, M. A. Chieda, J. M. Bates, R. E. Bauer, N. S. Cannon, B. E. Hey, C. G. Linschooten, F. J. Reitz, and E. R. Siciliano, 1997, Preliminary Retained Gas Sampler Measurements for Hanford Waste Tanks 241-AW-101, 241-A-101, 241-AN-105, 241-AN-104, and 241-AN-103, PNNL-11450, Pacific Northwest National Laboratory, Richland, Washington.

Sorokin, Yu. A., and S. Ya, Pshezhetskii, 1964, "Decomposition of Ammonia from the Action of Gamma Rays," Zh. Fiz. Khim., Vol. 38(3), 798-801, Chemical Abstacts, Vol. 61, 1419.

Spinks, J. T. W., and R. J. Woods, 1990, An Introduction to Radiation Chemistry, John Wiley and Sons, New York.

Stauffer, L. A., and L. M. Stock, 1999, Origins of Volatile Organic Compounds Emerging from Tank 241-C-106 during Sluicing, HNF-4261, Rev. 1, Lockheed Martin Hanford Corp. for Fluor Daniel Hanford, Inc., Richland, Washington.

Stern, M. K., M. P. Jensen, and K. Kraner, 1996, "Peroxynitrate Decomposition Catalysts," J. Am. Chem. Soc., Vol. 118, p. 8735.

Stock, L. M., 1992, Minutes of The Tank Waste Science Panel, W. W. Schultz and D. M. Strachan, Compilers, PNL-8274, Pacific Northwest Laboratory, Richland, Washington.

Stock, L. M., and J. L. Huckaby, 2000, Organic Compounds in the Headspaces of Single-Shell Waste Tanks, PNNL Letter Report, Pacific Northwest National Laboratory, Richland, Washington.

Strachan, D. M., 1994, Status and Integration of Gas Generation Studies Performed for the Hydrogen Safety Program-FY 1993, PNL-9459, Pacific Northwest National Laboratory, Richland, Washington.

Su, Z., D. D. Falvey, U. C. Yoon, and P. S. Mariano, 1997, "The Dynamics of alpha-Anilino Carboxylate and Related Cation Radical alpha-Heterocyclic Fragmentation," J. Am. Chem. Soc., Vol 119, p. 5261.

Tabata, Y., Y. Ito, and S. Tagawa, 1991, Handbook of Radiation Chemistry, CRC Press, Boca Raton, Florida. 


\section{RPP-6664 REV 0}

Teats, M. C., 1982a, 242-A Evaporator Campaign 80-10 Post Run Letter, RHO-SD-WM-PE-006, Rockwell Hanford Operations, Richland, Washington.

Teats, M. C., 1982b, 242-A Evaporator Campaign 81-1 Post Run Letter, RHO-SD-WM-PE-007, Rockwell Hanford Operations, Richland, Washington.

Thomas, J. M., and W. J. Thomas, 1969, Introduction to the Principles of Heterogeneous Catalysis, Academic Press, New York, p. 408.

Toste, A. P., 1998, "Gamma Ray Induced Destruction of Nitrilotriacetic Acid in a Simulated Mixed Nuclear Waste: The Radiolytic and Chemical Forces," J. Adv. Ox. Tech., Vol. 3, p. 70 .

Touser, O., 1953, "The Nitrosation of Aliphatic Carbon,” Organic Reactions, Vol. VII, p. 327.

Van Der Puy, M., 1985, Hydroxylamine. Redox Properties of Hydroxylamines Part 2. Organic Reactions, Buffalo Research Laboratories Allied Corporation, Buffalo, New York.

Van Der Puy, M., and , J. H. Dimmit, 1985, Hydroxylamine. Redox Properties of Hydroxylamines Part 1. Inorganic Reactions, Buffalo Research Laboratories Allied Corporation, Buffalo, New York.

Wahl, K. L., J. A. Campbell, S. A. Clauss, B. D. Lerner, A. K. Sharma, A. J. Saenz, I. E. Burgeson, R. L. Sell, K. E. Grant, G. M. Mong, C. E. Pederson, S. A. Bryan, and R. D. Scheele, 1995, Advanced Organic Analysis and Analytical Methods Development: FY 1995 Progress Report, PNNL-10777, Pacific Northwest National Laboratory, Richland, Washington.

Webb, A. B., J. L. Stewart, D. A. Turner, M. G. Plys, G. Malinovic, J. M. Grigsby, D. M. Camaioni, P. G. Heasler, W. D. Samuels, and J. J. Toth, 1995, Preliminary Safety Criteria for Organic Watch List Tanks and the Hanford Site, WHC-SD-WM-SARR-033 Rev. 0, Westinghouse Hanford Company, Richland, Washington.

Wilkins, N. E, 1995, Tank 241-SY-103 Core Sample: Interpretation of Results, WHC-SD-WM-TI-712, Rev. 0, Westinghouse Hanford Company, Richland, Washington.

Wilkins, N. E., R. E. Bauer, and D. M. Ogden, 1997, Results of Vapor Space Monitoring of Flammable Gas Watch List Tanks, SD-WM-TI-548, Rev. 0A, Lockheed Martin Hanford Corp., Richland, Washington.

Wilkinson, R. W., and T. F. Williams, 1961, "The Radiolysis of Tri-n-alkyl Phosphates," J. Chem. Soc., p. 4098.

Windholz, M., S. Budavari, L. Y. Stroumtsos, and M. N. Fertig, Editors, 1976, Merck Index, Ninth Edition, Merck and Co., Inc., Rahway, New Jersey.

Wolfenden, R., C. Ridgeway, and G. Young, 1998, "Spontaneous Hydrolysis of Ionized Phosphate Monoesters and Diesters and the Proficiencies of Phosphatases and Phosphodierterases," J. Am. Chem. Soc., Vol. 120, p. 833. 


\section{RPP-6664 REV 0}

Woodrich, D. D., G. S. Barney, G. L. Borsheim, D. L. Becker, W. C. Carlos, M. J. Klem, R. E. van der Cook and R. L. Ryan, 1992, Summary of SST Stability, WHC-EP-0347 (Supplement), Rev. 0, Westinghouse Hanford Company, Richland, Washington.

Zeldes, H., and R. Livingston, 1968, Paramagnetic Studies of Liquids During Photolysis. VI. Aliphatic Nitroanions, J. Am. Chem. Soc., Vol. 90, pp. 4540-4544. 


\section{RPP-6664 REV 0}

This page intentionally left blank. 